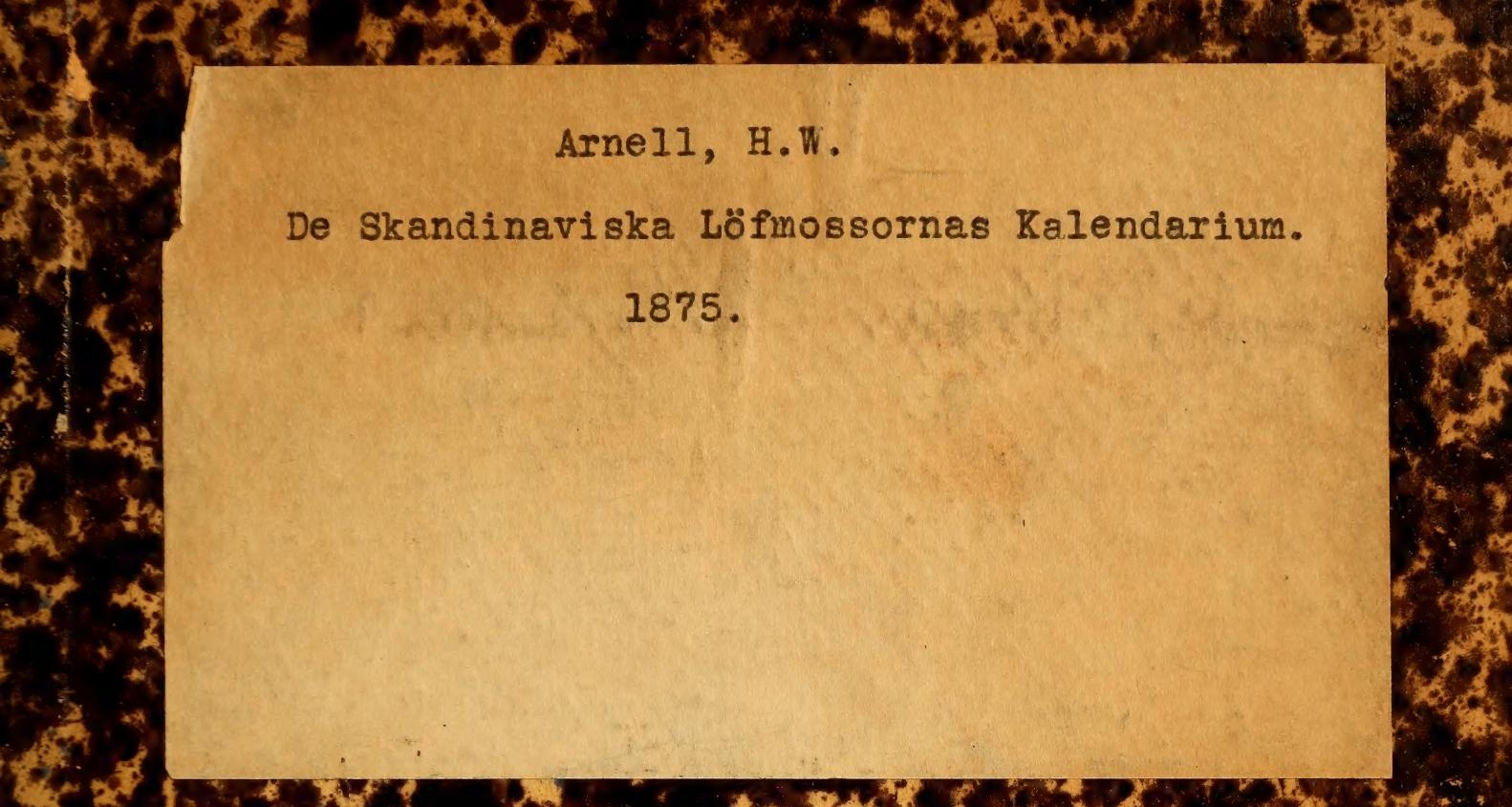

52

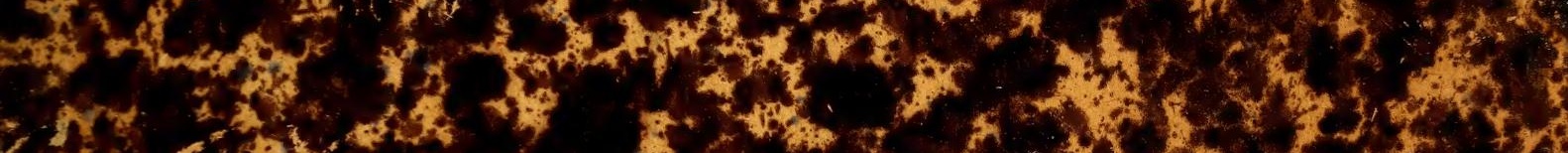

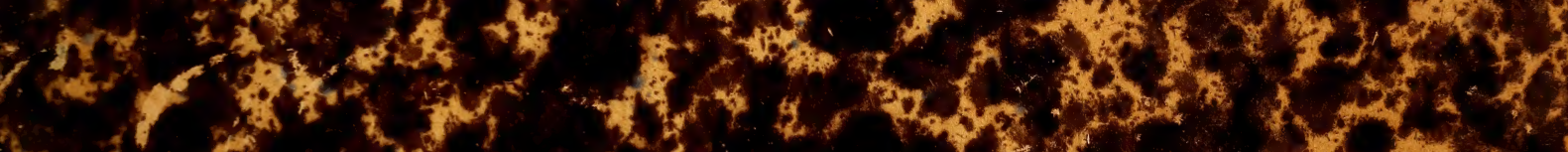

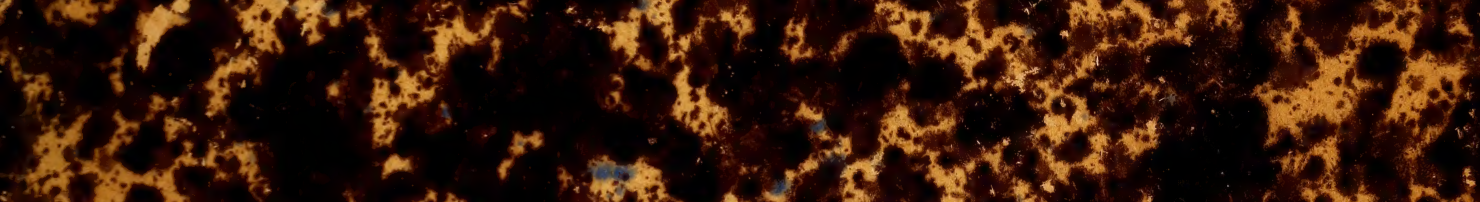

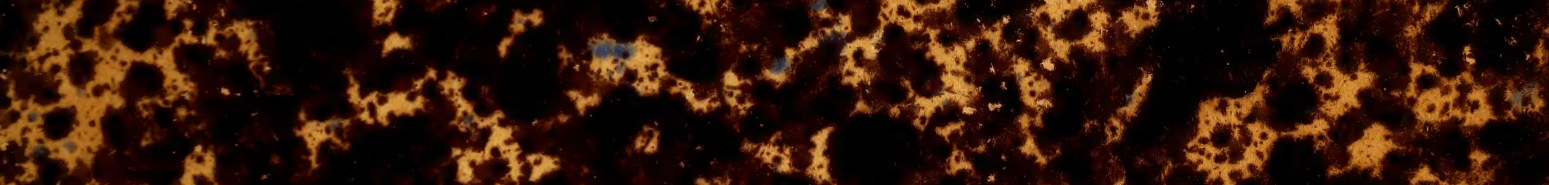

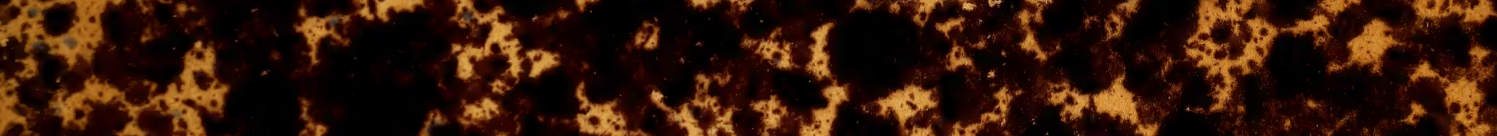
W

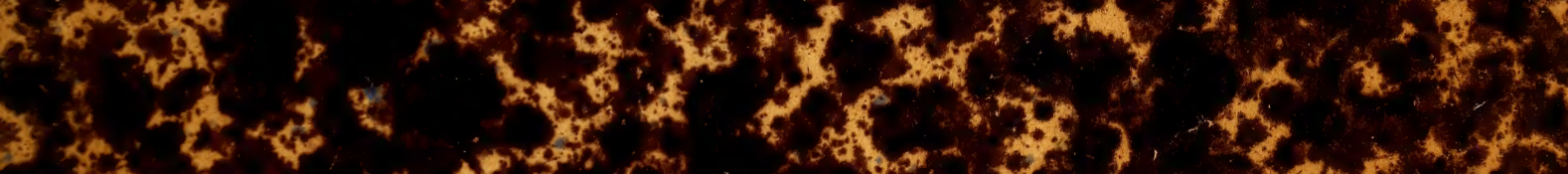

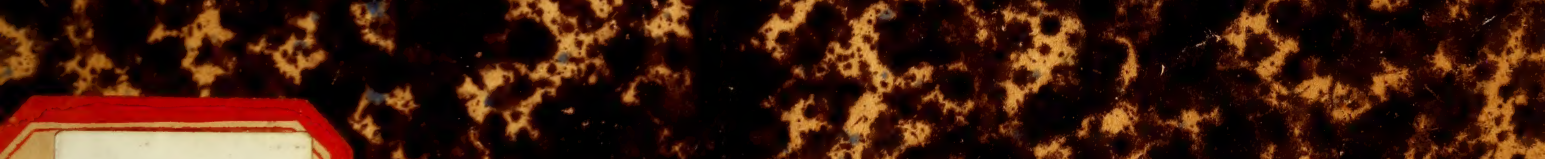

QK

544

S2A72 $1875 \mathrm{Z}$ Bot.

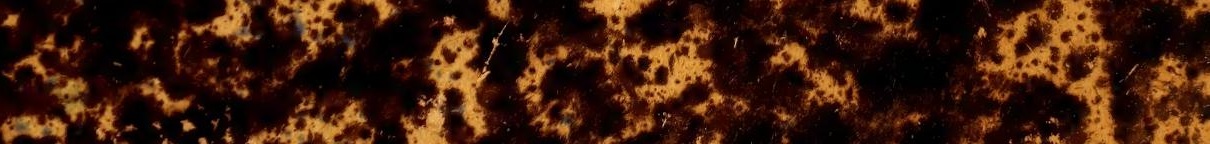

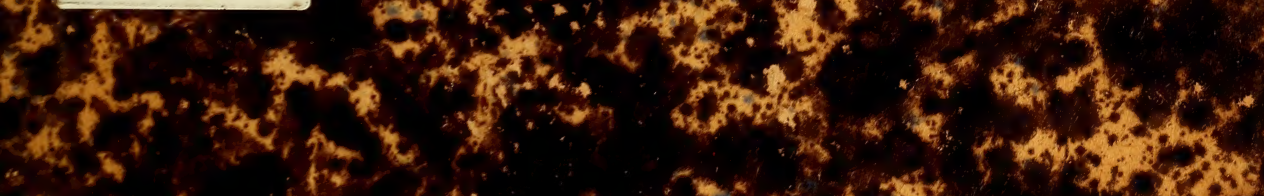

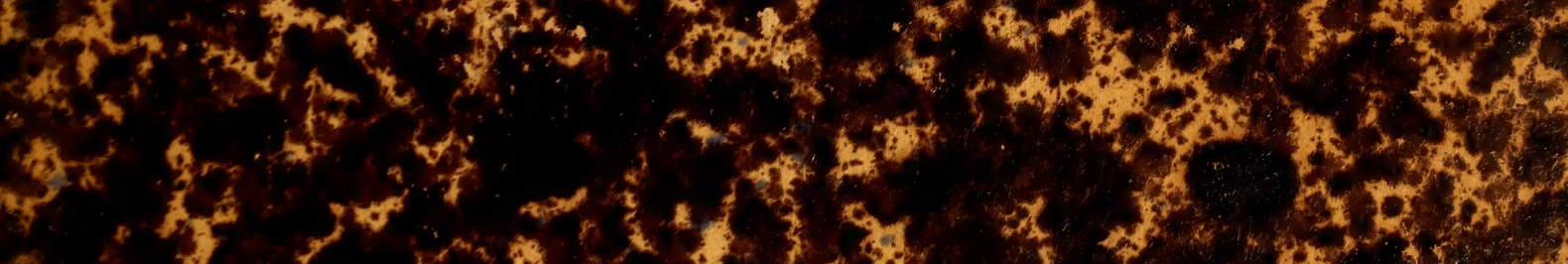
\% सhy

44.

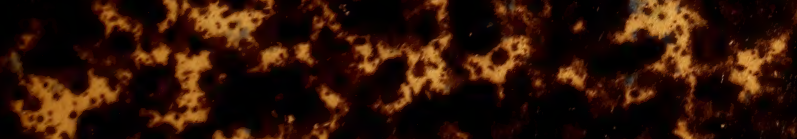





\section{DE SKANDINAVISKA LÖFMOSSORNAS}

\section{KALENDARIUM.}

AKA DEMISK AFHANDLING

$\Delta$

HAMPUS WILHELM ARNELL.

Upsala Universitets Årsskrift 1875.

Mathematik och Naturvetenskap. IV. 



\title{
De Skandinaviska Löfmossornas kalendarium.
}

\author{
Af
}

H. Wilh. Arnell.

$\mathrm{F}$

anerogamvegetationens olika utseende under årets olika tider har redan sedan länge varit uppmärksammadt och gjordt till föremål för studier äfven $\mathrm{i}$ fråga om våra Skandinaviska förhållanden. I våra floristiska arbeten stå åtminstone blomningstiderna allmänt angifna för de serskilda arterna. Dessa uppgifter äro dock splittrade, så att af dem ingen helgjuten bild af vegetationens utseende $\mathrm{i}$ afseende på blomstringen under årets olika tider kan vinnas utan ett serskildt sammanställningsarbete af läsaren. Mera uteslutande fästas afseende på växtlighetens utveckling efter årstiderna af Linné i afhandlingen »Calendarium Florae», i hvilken lemnas ett storartadt bidrag till kännedomen om växtlighetens utveckling efter årstiderna vid Upsala. Dessutom har våren och växtlighetens framskridande utveckling under densamma varit föremål för mångfaldiga iakttagelser. Redan Linné har i sin afhandling: „Vernatio Arborum» grundligt studerat och utredt tiden för trädens löfsprickning inom Sveriges olika delar. „Botaniska notiser» börja vid deras första utgifvande af A. E. Lindblom 1839 med en uppsats af Prof. E. Fries om > Vårens antåg», och i årgångarne från 1839-46 af nämnda tidskrift finnas flera uppsatser af olika författare, hvilka lemna vigtiga bidrag till kännedomen om tiden för vårens antåg på olika ställen af Sverige. Slutligen har Prof. E. Fries i den 1842 tryckta och i „Botaniska Utflygter I» intagna afhandlingen: $0 \mathrm{~m}$ vårens med sin vanliga mästarehand lemnat en lefvande skildring af denna årstid. De förutnämnda källorna äro de förnäm- 
sta, som vi hafva, för kännedomen om vårt Skandinaviska fanerogam-kalendarium. Ifrån och med år 1873 har dessutom Meteorologiska Observatorium i Upsala till iakttagare inom hela Sverige utsändt listor, på hvilka tiden för de antecknade företeelserna skall af hvarje iakttagare ifyllas. På dessa listor äro antecknade 48 lätt igenkänliga fanerogamer, för hvilka tiden för blomning och stundom fruktsättning, samt för träd och buskar äfven för löfsprickning och löffällning skall antecknas, samt dessutom några vid bestämda tider bundna företeelser ur djurverlden och från åkerbruket. Genom dessa listor torde i en snar framtid en säker grund blifva lagd för kännedomen om gången af växtlighetens utveckling under året inom Sverige. Listorna äro isynnerhet af stort värde genom den goda urskiljning, hvarmed observations-föremålen äro valda, och genom den enighet i iakttagelserna, som genom dem blir rådande. Förf. begagnar derför tillfället att anbefalla alla för saken intresserade att skaffa sig sådana listor, hvilka kostnadsfritt erhållas från Meteorologiska Observatorium i Upsala.

I fråga om kryptogamerna har Prof. E. Fries 1) framstält de för årets olika tider ntmärkande svamparne. För öfrigt har kryptogamernas kalendarium blifvit försummadt förutom de uppgifter, som spridda finnas i våra floristiska arbeten, om de tider, då enskilda arter eller ibland flera närslägtade arter äro i sitt vackraste tillstånd, vanligen af blomning eller fruktsättning.

I det följande har förf. sökt fylla en af luckorna $i$ kännedomen om hela växtlighetens olikheter under årets olika tider, i det han framstält ett kalendarium för de Skandinaviska löfmossornas blomning och fruktsättning. Antalet arter af löfmośsor, som finnas i Skandinavien och varit föremål för förf:s undersökningar, uppgår till nära 600 . Ibland dessa hafva några ej varit författaren tillgängliga i tillräckligt antal exemplar af den beskaffenhet, att de kunnat lemna tillförlitlig kunskap om blomningsoch fruktsättningstiderna. Dock har det då i de flesta fall varit möjligt att sluta till dessa arters blomnings- och fruktsättningstider från analogi med närslägtade arter.

Det område, som förf. utstakat för sina undersökningar, är Skandinavien i den mening, hvari det tages af Lektor C. Hart-

1) Uti afhandlingen: “Svamparnes Calendarium under mellersta Sveriges horisonte (intagen i Bot. Utflygter III och utförligare i Kongl. Vet.-Ak:s Förhandl. 1857). 
man $\mathrm{i}$ Skandinaviens Flora», d. v. s. lika med Sverige och Norge. Detta är visserligen ej den betydelse, som för närvarande fästas vid Skandinavien i växtgeografiskt hänseende, i hvilket äfven Danmark, Finland och Ryska Lappmarken måste derunder förstås. Förf. har dock ansett sig berättigad att benämna deuna afhandling: „De Skandinaviska Löfmossornas kalendarium», ehuru endast de Svensk-Norska mossorna äro i densamma afhandlade, dels emedan namnet Skandinavien äfven i ofvannämnda mera inskränkta betydelse vunnit häfd genom Hartmans Flora, och dels äfven emedan det stora flertalet mossor, som finnas i Skandinavien äfven $i$ dess mera vidsträckta betydelse, äro $i$ det följande afhandlade ${ }^{1}$ ).

För sina undersökningar har förf. dels gjort naturstudier och dels äfven begagnat sig af moss-samlingar. Under åren 1868-75 har förf. haft tillfälle till naturstudier dels i Sverige, förnämligast i mellersta delen, eller i Hernösands-trakten, men äfven i sydligare delar till och med Vestergötland, dels äfven under somrarne $1869-70$ i Norge, isynnerhet i trakterna kring polcirkeln och i Trondhjems stift. Serskildt hafva förf:s naturstudier året 1874 i mellersta Skandinavien varit rigtade på till detta kalendarium hörande frågor. Utom sina egna moss-samlingar har förf. för sina studier $\mathrm{i}$ detta ämne genom egarnes tillmötesgående äfven fått genomgå flera andras. Sålunda har förf. haft tillfälle att genomgå moss-samlingar tillhörande Herr Stud. W. Berndes, Herr D:r J. G. Théel, Docenten Herr D:r H. E. Hamberg, Herr Prof. D:r Hj. Holmgren, Studentkåren i Upsala och Herr Med. Doktor J. Ångström, och hembär förf. härmed nämnda samlingars egare eller vårdare den lifligaste tacksamhet för deras mot honom visade godhetsfulla tillmötesgående att upplåta sina samlingar.

Slutligen må det omnämnas, att den af Lektor C. Hartman i skandinaviens Floras, 10:de uppl., begagnade nomenklaturen är i det följande använd. Förf. har afvikit från densamma endast $i$ ett afseende, nemligen deruti att de derstädes ofta förekommande, långsläpiga adjektiv-formerna af personnamnen blifvit förändrade till genetiver, så att t. ex. namnet Hypnum Haldanianum blifvit ändradt till $H$. Haldanii o. s. v.

1) Så vidt förf. kănner tillkomma nemligen i Skandinavien i dess mera vidsträckta betydelse endast 22 arter löfmossor, hvilka ej blifvit funna i Sverige eller Norge. 
Redan det vegetativa systemet visar hos löfmossorna under årets olika tider stora olikheter. Nyskottens mer eller mindre starka utveckling, deras oftast från de äldre delarne olika färgning och deras under olika utvecklingsstadier olika yttre habitus äro mycket intressanta att under en vegetationstid följa. I det följande har dock förf. lemnat det vegetativa systemets olikheter allt efter årets olika tider a sido för att följa de utvecklade blommornas ${ }^{1}$ ) och frukternas hos de olika arterna uppträdande på olika tider af året. Förr än förf. öfvergår till det egentliga kalendariet, torde dock några anmärkningar först om blomningen och sedan om fruktmognaden vara på sin plats.

\section{Blomning.}

Löfmossornas serskilda arter hafva sina bestämda tider för blomningen, eller befruktningen. Redan en närmare bekantskap med andra växter hänvisar oss till visshet härom, derigenom att vi se, att hos dem vissa bestämda tider åt de olika arterna äro anvisade såsom de för blomningen ändamålsenligaste. Onaturligt vore det om mossorna härifrån skulle göra något undantag. Ãfven derifrån, att, såsom sedan gammalt är bekant, mossfrukterna hos hvarje art vanligen samtidigt mogna på en bestämd och ofta mycket inskränkt tid af året, kunna vi sluta dertill, att frukterna äfven blifvit samtidigt anlagda, hvilket sker vid blomningen. Emellertid hafva de serskilda arternas blomningstider hos löfmossorna hittills varit i de flesta fall helt och hållet obekanta. Orsaken härtill är troligen den, att mossblommorna i allmänhet äro små och oansenliga, så att de lätt undgå uppmärksamheten. Endast hos några akrokarpiska familjer, Polytrichaceae, Bryaceae och Splachnaceae, äro nemligen hanblommorna oftast genom en prydligare utstyrsel mera i ögonen fallande.

1) Mossblommor hafva för förf. i denna afhandling samma betydelse som de $\mathrm{i}$ allmänhet för Bryologer allt ifrån Hedwigs tid hafva haft. Angående den af Prof. S. O. Lindberg $i$ afhandlingen: "Torfmossornas byggnad, utbredning och systematiska uppställning $i$ Vet. Akad:s Öfvers. 1862 samt i samma Öfversigt sidd. 608 och 609 framstälda nya åsigten om hvad, som bör betraktas såsom on mossblomma, făr förf. här inskränka sig till sitt omdöme, att den ej synes honom naturlig. Förf. hoppas i en onar framotid få återkomma till denna fråga. 
Endast högst f̊a äro derföre de uppgifter, som finnas om blomningstiden hos löfmossorna. I »Bryologia Europaea» af Bruch, Schimper och Gümbel finnas sådana direkta uppgifter endast vid Leptobryum, Tortula, Schistidium och de nanandriska Dicrana. Dessutom står blomningstiden indirekt angifven vid några få mossor, nemligen vid Catharinea, Discelium, Cinclidotus och Trichostomum, i det att tiden för fruktmognaden står angifven samt äfven den tid, som frukten behöfver för sin utreckling. Dessa uppgifter öfverensstämma dock ej med de Skandinaviska förhållandena, förf. vågar tro ofta till och med knappast med förhållandena på något ställe i Europa. Tortula-arterna sägas t. ex. vanligen blomma uti Juli och Augusti och använda 8-10 månader på fruktutvecklingen. Många af slägtets arter såsom Unguiculatae och Tortulae i egentlig mening blomma dock i Juni och använda högst 8 månader, ofta blott 6 på fruktutvecklingen. Andra deremot såsom Tortuosae och Syntrichia blomma visserligen i Juli och Augusti, men använda öfver 10 månader på fruktutrecklingen. I $>$ Synopsis muscorum $>$ af Schimper finnas ännu färre uppgifter om blomningstiden. Ett exempel lemnar dock Buxbaumia aphylla, för hvilken den är angifven »ineunte auctumno», hvilket dock ej slår in med våra förhållanden. I »Botanische Zeitung 1860 sidd. 344-45 finnes en uppsats af $\mathrm{Dr} \mathrm{H}$. von Klinggräff, i hvilken blomningstiden för temligen många mossor står angifven. Iakttagelserna äro dock gjorda i Preussen och passa delvis ej in på Skandinavien. Slutligen börjar tidskriften »Revue Bryologique» $\mathrm{i}$ sitt första häfte år 1874 med en kort uppsats af E. Roze: $\gg$ De l'utilité de faire connaître l'époque de la fécondation chez les muscinées». Blomningstiden finnes i denna uppsats angifven för 16 löfmossor, men har förf. af uppsatsen begått det stora felet att ej utsätta, på hvilket ställe på jorden de omnämnda mossorna blomma på de angifna tiderna. Genom detta fel förlorar denna uppsats allt värde. I det föregående har förf. omnämnt alla de uppgifter, som han vet finnas om mossornas blomningstid. Det synes deraf, att förf. $\mathrm{j}$ det stora hela haft så godt som inga föregångare $\mathrm{i}$ sina undersökningar, utan har han utan handledning sjelf fått leta sig fram mellan skären.

Vid blomnings-tidens eftersökande blir första frågan: hvar finnas årets blommor? Årsblommornas läge, likasom i allmänhet blommornas läge, är olika hos de två stora afdelningarne af löfmossorna, de pleuro- och de akrokarpiska mossorna. De pleuro- 
karpiska mossorna hafva alltid blommorna terminala på korta »blomgrenar», hvilka utgå från de primära eller sekundära hufvudaxlarne, eller hanblomgrenarne äfven stundom från biaxlarne. De äro sålunda alltid minst biaxila, aldrig uniaxila. Vanligen äro årets blomgrenar sidostående utefter de under fjolåret utvecklade nyskotten. Dessa skilja sig oftast från de nedre och äldre delarne af mossan genom en olika och friskare färg. Gränsen mellan denna olika färgning af de yngre lifskraftiga nyskotten på den ena sidan och af de äldre, förvissuande delarne på den andra utvisar hos dessa mossor äfven gränsen mellan årets blommor och de möjligen från föregående år qvarvarande, på samma gång som denna olika färgning af de yngre, och äldre delarne ofta gifver mossorna ett karakteristiskt utseende. Hos en del mossor är färgbrytningen mellan de yngre och äldre delarne mycket vacker. Vanligast äro de nedre och äldre delarne gulbruna, de öfre gröna såsom t. ex. hos Anomodon. Stundom skilja de sig endast genom en mer eller mindre frisk, grön färg. Hos Hypnum badium äro fjolårets tillika med årets skott guldgula, de nedre äldre delarne deremot vackert kastanjebruna. Hos Eurhynchia crassinerve och Vaucheri äro de yngre delarne guldgula och de nedre gröna; genom sin lösare byggnad skilja sig dessutom nyskotten hos dessa mossor så betydligt från de äldre delarne till sin habitus, att man knappt tror dem tillhöra samma slägte. Färggränsen utgör, såsom sagdt är, gränsen mellan årets och de föregående årens blommor. Myurella-arterna visa dock ett undantag från denna regel; hos dem sitta årets blommor straxt under färggränsen. Fontinalis-arterna göra ett undantag från den allmänna regeln, i det att hos dem aldrig årsblommor finnas på de öfre och yngre axlarne, utan alltid på de nedre och fleråriga. Helt abnormt har förf. dessutom hos Brachythecium Rutabulum funnit årsblommor på äldre delar af stjelken. Sålunda funnos han- och honårsblommor nedom fjolårets fruktskaft på ex. från Södml. $\frac{15}{6} 68$ och unga hanblommor nedom en gammal eller fjolårets honblommma på ex. från Ner. $\frac{6}{4} 73$.

De normala akrokarpiska mossorna hafva blommorna terminala på de vegetativa axlarne, aldrig på blomgrenar; de äro sålunda uniaxila. De vegetativa axlarne äro begränsade i sin tillväxt af blommor, hvilket aldrig är fallet hos de pleurokarpiska mossorna. Årsblommorna äro terminala på de öfversta och yngsta axlarne. Alstras på samma års-skott flera blommor, så kunna dessa antingen stå jemnsides på toppen af samma axel 
såsom t. ex. hos Bartramiae Halleri, crispa och Normanni ${ }^{1}$ ), eller ock äro årsblommorna ensamma och terminala på hvar sin axel. Då på samma årsskott flera årsblommor finnas terminala på hvar sin axel, äro blommorna olikgamla och axlarne äfven af olika ålder och ordning. Detta är olikt förhållandet hos de pleurokarpiska mossorna, hos hvilka årsblommorna, ehuru sittande p̊ olika höjd, alltid äro af lika ålder, och samma års blomgrenar åtminstone af lika kön oftast äro af samma ordning. Talrika årsblommor på samma årsskott äro, åtminstone talrika honblommor, sällsyntare hos de akrokarpiska mossorna, än hos de pleurokarpiska, men hos de monoika akrokarpiska mossorna finnas dock, utom hos Catharinea undulata och Tetraphis, minst 2 blommor, nemligen en han- och en honblomma, på samma årsskott. Hanblomman utvecklas först och är terminal på sin axel; straxt under hanblomman utvecklas sedan ett eller två nyskott, på hvilka honblommorna äro terminala. Härigenom komma alltid hanblommorna att hos de monoika akrokarpiska mossorna sitta under honblommorna och på axlar af lägre ordning än dessa. Om under hanblomman endast ett nyskott utvecklas, så utvecklas detta vanligen så starkt, att det skjuter hanblomman på sidan och denna blir skenbart sidostående, sålunda erinrande om de pleurokarpiska mossornas verkligt sidostående blommor. Stundom kunna hos de monoika akrokarpiska mossorna först flera hanaxlar med på dem terminala hanblommor alstras öfver hvarandra, innan under den öfversta hanblomman honaxelbildning börjar. Sedan honaxelbildningen börjat, alstras under samma år endast honaxlar; dock alstras endast sällan under ett år honaxlar af mera än en ordning, d. v. s. oftast blott de en eller två honaxlar, som utgå från den öfversta hanblomman. Hos de monoika akrokarpiska mossorna sitta således vanligen honblommorna terminala på axlar, som utgått såsom skott under de lägre hanblommorna. Hos dessa mossor kan man derför på förhand vara säker derom, att efter hanaxelbildningen under samma år en honaxelbildning skall följa. Endast några få monoika arter göra härifrån undantag, $\mathrm{i}$ det att de hafva serskilda hangrenar, på hvilka alltid blott hanaxelbildning eger rum utan följande honaxelbildning. Exempel härpå lemna

') Bartramia Normanni är monoik likasom B. crispa, den har ej samkönade blommor såsom Lektor C. Hartman uppgifver. Jfr गSkand:s Flora) 10:de uppl. pag. 47. 
de monoika Andraea-arterna och enligt Prof. S. O. Lindberg, som kallar denna blomställning klado-autoik, Orthotricha Rogeri och polare samt Ulota curvifolia $\left.{ }^{1}\right)$. Catharinea undulata och Tetraphis äro äfven monoika, men visa olikheter från de öfriga monoika akrokarpiska mossorna. Hos Catharinea undulata afslutas enligt »Bryologia Europaea» den uppräta stängeln första året nästan alltid med en hanblomma. Nästa år genomborras denna hanblomma af ett nyskott, hvilket afslutas med en honblomma, och sedan utvecklas endast honaxlar genom nyskott-bildning under honblommorna. Utvecklingsföljden är här likartad med den hos monoika arter vanliga, men olikheter visa sig deruti, att han- och honaxelbildningen är fördelad på olika år, och deruti, att skottbildningen här eger rum ej under utan genom hanblomman 2). Tetraphis visar enligt Bryol. Eur. en ännu större olikhet från de vanliga monoika akrokarpiska mossorna. Hos detta slägte utveckla sig nemligen honaxlar med terminala honblommor under det första året, sedan utveckla sig genom skottbildning under de sterila honblommorna nästa år hanaxlar med terminala haublommor. Hanblommorna komma sålunda hos detta slägte att sitta högre och på axlar af högre ordning än honblonımorna. Härigenom visar Tetraphis en viss likhet med de monoika pleurokarpiska mossorna, hos hvilka förf. funnit hanblommorna sitta ofvan honblommorna, men här på samma årsskott. Endast hos Thujidium Blandowii och Hookeria har förf. funnit samma års han- och honblommor sitta blandade om hvarandra.

I det föregående hafva vi talat om de normala akrokarpiska mossorna och årsblommornas läge hos dem. Det finnes äfven några till de akrokarpiska hänförda mossor, som visa tydliga öfvergångar till de pleurokarpiska genom blommornas sidostående läge. Dessa hafva blifvit kallade kladokarpiska, emedan blommorna och sedan frukterna hos dem äro terminala ej på rena blom-

1) Sistnämnda art är dock enligt förf:s erfarenhet normalt monoik.

$\left.{ }^{2}\right)$ Blommorna genomborras af nyskott endast hos få Skandinaviska löfmossor. Utom hos Catharinea undulata, genomborras sålunda hanblommorna hos Polytrichaceae (och enligt Prof. Lindberg äfven hos Timmia austriaca) och honblommorna hos Bryum roseum. Hos Polytrichum formosum har förf. såsom en abnormitet funnit samma utvecklingsföljd, som hos Catharinea undulata. Pa en hanstjelk, som visade flera genomborrade hanblommor ofvan hvarandra, hade öfversta axeln afslutats med en honblomma, som befruktats och visade en fullt utvecklad frukt. 
grenar, såsom hos de pleurokarpiska mossorna, utan på äfven vegetativa blad, bärande, korta grenar. Dessa mossor äro sålunda äfven biaxila. En väsendtlig skiljaktighet visa dock dessa skenbara blomgrenar hos de kladokarpiska mossorna från verkliga blomgrenar äfven deruti, att de, utom hos Cinclidotus, hafva en tydligt utvecklad vaginula, hvilken saknas hos alla pleurokarpiska mossor. Rena kladokarpiska löfmossor äro endast Mielichhofferia och Anoectangium inom vår Skandinaviska flora, och är blommornas läge hos dem alltid sidostående, likasom hos de pleurokarpiska mossorna. Octodiceras och några Fissidens-arter blifva äfven kladokarpiska, de första blommorna unläggas dock, såsom det synes af planscher i Bryol. Europ. öfver Octodiceras och Fissidens taxifolius, fullkomligt lika som hos de akrokarpiska mossorna. Cinclidotus vacklar allt efter sin växtlokal mellan den akro- och pleurokarpa typen. De mera rikligt förgrenade Racomitria och Archidium visa sig äfven ofta kladokarpa. Hos de ofvannämnda kladokarpa mossorna äro årsblommorna ej att söka på de obegränsadt fortväxande hufvudaxlarne, utan äro de sidostående terminala på biaxlar vanligen utefter stjelkens yngre delar.

Ett serskildt omnämnande torde här i sammanhang med frågan om årsblommornas läge de nanandriska mossorna förtjena. Hos några mossor t. ex. Hypnum pratense, eallichroum och hamulosum 1) m. fl. pleurokarpiska, samt bland de akrokarpiska hos några af de större Dicrana, t. ex. D. robustum, och hos Leucobryum förefinnas dvärghanplantor (nanandres), hvilka till sin storlek äro ytterst reducerade, så att de knappt utgöra annat än rotslående blommor, som uppträda såsom egna individer. Endast dvärghanplantor finnas hos somliga arter, t. ex. hos Dicrana robustum och undulatum; hos andra arter hafva äfven normala, med honplantorna lika utvecklade hanplantor blifvit funna jemsides med dvärghannarne, t. ex. hos Dicrana fuscescens och

1) Hypnum hamulosum angifves allmänt vara monoik. Förf. har dock aldrig på de talrika ex., han undersökt, lyckats finna annat än honblommor. Likaså hafva Molendo och Juratzka aldrig funnit han- och honblommor pả samma individ af denna art. Jfr Molendo: "Moos-Studien aus den Algäuer Alpen"). (Augsburg 1865). Arten måste derför vara dioik. Om någon hanblomna blifvit funnen på ett honindivid, så var detta troligen en dvärghanplanta. Beskrifningen i Bryol. Eur. bestyrker äfven denna förmodan, emedan antheridierna, framställas såsom ovanligt små orh parafyser i hanblomman saknas; bvilket väl öfverensstämmer med törhảl landena hos dvärghanplantornas blommor. 
scoparium. Dvärghanplantorna uppstå troligen alltid från sporer, och beror derför deras läge af, på hvilket ställe sporan grott. Ofta förekomma de parasitiskt på moderväxten, på dess blad eller hos Dicrana vanligen på den med rikligt ludd försedda stjelken. Dvärghanplantorna äro enåriga, om de befinna sig parasitiskt; hafva de grott på marken, så kunna de troligen utveckla sig flerårigt och blifva då, om arten ej eger utvecklade hanplantor, genom förändring af könet honplantor enligt Bryol. Europ. De nanandriska mossorna kallas af sehimper pseudomonoika, af Prof. Lindberg pseudoautoika. Dessa oftast parasitiska dvärghanplantor äro intressanta, emedan de äro analoga till de hos en del arter af algslägtet Oedogonium befintliga, äfvenledes parasitiska dvärghanplantorna.

I synnerhet äro naturligtvis de fullt utvecklade blommorna, som just äro mogna att befrukta eller befruktas, upplysande om mossornas blomningstid, och är det i främsta rummet sådana blommor, som för detta ändamål böra uppsökas. Det är mycket lätt att se, när blommorna äro mogna. Antheridierna äro då antingen alla eller ifrån början åtminstone till en del öppna, men de hafva ej ännu tömt sitt innehåll. Har man lefvande, utvecklade antheridier preparerade i vatten under mikroskopet, så lemna de i mängd sig frigörande och kringsvärmande antherozoiderna intet tvifvel om deras mognad. Sa länge antheridierna ej ännu äro fullt tömda, äro de vanligen färglösa, och väggarnes cellulösa byggnad framträder ej klart. De tömda antheridierna blifva deremot genast brunt eller mera sällan hos Bryaceae violett färgade, och väggarnes cellulösa väfnad framträder hos dem skarpt tydlig. Antheridierna antaga genom denna färgning vid öfvermognad genast ett gammalt och vissnadt utseende.

I den utvecklade hon- eller samkönade blomman äro antingen alla arkegonierna eller från början blott en del af arkegonierna öppna. Arkegoniernas hals är frisk och dess kanal antar vanligen, ifrån att förut hafva varit ofärgad, samtidigt med att arkegoniet öppnas, en vacker brun eller stundom purpur-violett färgning. Sällan blir halsens kanal färgad redan kort före arkegoniets öppnande, och lika sällan träffar man öppna arkegonier med ofärgade halsar. Det senare inträffar dock ofta hos några m̧ossor, hos hvilka arkegonierna hafva en fastare byggnad och derigenom temligen länge efter befruktningen bibehålla ett friskt utseende, såsom t. ex. hos Polytricha och Orthotricha. I vanliga 
fall visa dock arkegonierna snart genom sin vissnade hals och genom sin småningom allt längre nedåt buken sig sträckande mörkare färgning, att de äro öfvermogna.

Äfven från unga eller gamla blommor kan man dock sluta till blomningstiden och blir man ofta trungen att begagna sig endast af sådana, då det för handen varande undersökningsmaterialet ej har just mogna blommor. Unga eller gamla blommor äro dessutom ofta goda hänvisare till den tid, på hvilken man kan finna fullt utvecklade sådana. Dock måste de med försigtighet användas, emedan man eljest lätt kan af dem blifva vilseledd.

Fästa vi oss först vid hanblommorna och vid antheridierna $\mathrm{i}$ de samkönade blommorna, så äro de genom den långa tid, under hvilken antheridierna före blomuingen äro tydligt utvecklade, goda häntydare på en förestående blomning. Huru långt aflägsen blomningstiden är, kan man dock ej af unga antheridier döma. Man kan ofta blifva narrad att antaga blomningstiden såsom alltför nära förestående, derigenom att antheridierna så långt före blomningen äro utvecklade. Antheridierna kunua nemligen vara fullt tydligt utvecklade redan flera månader före blomningen och undergå, âtminstone till det yttre, inga väsendtliga förändringar, utan förblifva hela tiden ända till blomningen sig lika. Sålunda kunna vi finna redan i Maj hanblommor med utvecklade och tydliga antheridier hos t. ex. sumphypna och Hypnum Crista castrensis, hos hvilka dock antheridierna blifva mogna först i Augusti. Hos mossor, som blomma tidigt på våren, äro hanblommorna redan på senhösten försedda med tydliga antheridier; så var det t. ex́. fallet med Leptotrichum flexicaule i Ner. $\frac{21}{11} 72$. Arkegonierna behöfva ej så lång utvecklings-tid, som antheridierna. En följd häraf blir det, att i samkönade blommor antheridierna blifva synliga långt före arkegonierna, hvarigenom man lätt kan förledas att tro, att unga samkönade blommor äro enkönade. Så t. ex. voro hos Mnium cuspidatum i unga blommor blott antheridier synliga på exemplar från Upsala ${ }_{5} 70$, Ångml. $\frac{8}{6} 69$, Södml. $\frac{8}{6} 69$ och ÖG. $\frac{1370}{6} 70$. Uti den omständigheten, att antheridierna behöfva en mycket längre tid än arkegonierna för sin utveckling, finna vi äfven en naturlig förklaring derpå, att hanblommorna alltid äro belägna under honblommorna hos de akrokarpiska mossorna. Hanblommorna måste nemligen anläggas före honblommorna för att hinna utveckla sig, så att de blifva mogna samtidigt med honblommorna. Hos några mossor t. ex. Orthotricha och 
Cynodontia hinna dock de äldre hanblommorna närmast under honblommorna ej till mognad, förrän de ofvan dem stående yngre honblommorna redan äro mycket öfvermogna. I synnerhet synes en sådan protogyni vaca normal hos Orthotricha. Hos de monoika pleurokarpiska mossorna förefinnes af samma anledning en blomutveckling i descendental rigtning, i stället för att organer i vanliga fall bruka utvecklas i akropetal rigtning. Årets hanblommor äro normalt belägna ofvanför årets honblommor hos de pleurokarpiska mossorna, men för att hanblommorna skola hinna till mognad samtidigt med honblommorna, måste de anläggas långt före dessa senare. Sålunda framträda de öfre hanblommorna helt tydligt, dock sinsemellan liktidigt, innan det ännu synes något spår af de sedan längre ned sinsemellan liktidigt fratnträdande honblommorna. Härigenom äro of́a exemplar med unga hanblommor vilseledande, när det är fråga om att bestämma könsförhållandet. Då man ej ser något spår af honblommor, kan man blifva förledd att tro, det mossan är dioik. De unga antheridierna äro ofärgade, eller hafva de en grön anstrykning. Mera sällan felslå antheridierna och få redan i unga blommor en vilseledande brun färgning, såsom t. ex. synes af förf:s iakttagelser på Hypnum giganteum $\mathrm{m}$. $\mathrm{fl}$.

Vid öfvermognad få antheridierna deremot så hastigt ett vissnadt utseende, att man från dem ej alls kan sluta till blommornas relativa ålder, utan endast dertill, att blomningen är slutad. Man kan ej på öfvermogna antheridier se, om de tillhöra en årets blomma eller någon blomma från de föregående åren. I en blomma med föga olikgamla antheridier kunna vid blomningen härigenom dessa fà utseende af att vara mycket olikgamla. De ännu fulla eller under tömning varande antheridierna äro friska och färgade, under det de fullt tömda redan äro bruna eller violetta samt synas vissnade och gamla.

Öfvergå vi till honblommorna och arkegonierna för att se efter, hvilka upplysningar de kunna lemna utom den egentliga blomningstiden, så finna vi först, att unga arkegonier alltid hänvisa på en snart förestående blomning. Vi hafva nemligen redan förut visat, att arkegonierna behöfva en mycket kortare tid för sin utveckling, än antheridierna. De öfvermogna arkegonierna äro länge upplysande om den ungefärliga tidrymd, som kan hafva förflutit sedan blomningen. De obefruktade afvissna nemligen ej så hastigt och på en gång, som antheridierna göra, utan afvissnandet sker så småningom, så att man ofta flera månader efter 
blomningen kan igenkänna dem såsom tillhörande årets blommor. Öfvermogna, samkönade blommor visa tydligt skilnaden mellan antheridier och arkegonier i detta afseende. Antheridierna synas redan alldeles förvissnade, då arkegonierna ännu delvis äro tydligt friska. Vi hafva redan omtalat, att arkegonierna efter blomningen, då de äro obefruktade, så småningom afvissna; den färgning som kanalen antog vid arkegoniets öppnande sträcker sig, efterföljd af förvissnandet, efterhand nedåt. Längst bibehåller sig foten frisk och ofärgad. Arkegonierna afvissna olika hastigt hos olika mossor. Hos Neckerae afvissna de nästan lika hastigt som antheridierna; hos dessa mossor har man derför ingen upplysning om blomningstiden att af honblommorna vinna efter blomningen, så vida de ej äfven hafva befruktade arkegonier. Hos de flesta andra löfmossorna kan man ännu en till flera månader efter blomningen se, att arkegonierna äro årets genom de ännu mer eller mindre friska nedre delarne af desamma. Isynnerhet äro Polytrichaceae och Ortotricha utmärkta för sina länge friska arkegonier. Hos de Orthotricha närstående Grimmiae äro deremot arkegonierna redan $2-3$ veckor efter blomningen så vissnade, att de knappast kunna igenkännas såsom tillhörande årets blommor. Exempel på arkegoniernas långsamma afvissuande lemna t. ex. Catharinea undulata från Hall. $\frac{26}{8} 68$, som efter 2 månader visade tydliga års-arkegonier, Hypnum pallescens från Ångml. $\frac{170}{6} 70$ och Ulota Bruchii från VG. $\frac{1}{6} 73$, hvilka två sistnämnda blommat på eftersommaren och ännu den $\frac{1}{6}$ nästa år visade temligen friska fötter. Tillbörlig uppmärksamhet måste vid begagnadet af vissnade blommor fästas på arkegoniernas mer eller mindre hastiga afvissnande hos olika mossor, emedan man eljest lätt misstager sig på dessa blommors ålder.

I gamla honblommor kunna stundom arkegonierna vara i högsta grad vilseledande derigenom, att de aldrig hafva öppnats, utan afvissnat slutna. Vanligen äro de då färgade, likt andra gamla arkegonier, samt visa ett vissnadt och skrumpet utseende. Redan då de äro i detta tillstånd, kan man blifva ganska trifvelaktig, om blommorna äro årets och ej ännu fullt utvecklade. Villan ökas ännu mera om färgningen med åldern försvunnit, så att arkegonierna äro ofärgade och slutna. Det är isynnerhet några mossor, som ofta visat sig ega slutna och stundom äfven ofärgade gamla arkegonier; serskildt hänvisar förf. på Anomodon longifolius samt dessutom på öfriga arter af samma slägte, på Neckerae m, fl. Arkegoniernas oftast vissnade utseende och blom- 
mornas läge på alltför åldriga delar af moss-stjelken lemna dock vanligen rum för misstankar, att dessa blommor ej äro så unga, som det vid första ögonkastet vill synas.

I de öfvermogna blommorna utvisa de befruktade arkegonierna, om sådana förefinnas, genom sin mer eller mindre starka utveckling den tid, som kan hafva förflutit sedan blomningen eller befruktningen. Sedan arkegoniet blifvit befruktadt, börjar i detsamma en liflig tillväxt. Från början är det i synnerhet buklagren och foten, som tillväxa, hvaremot centralblåsans celldelningar försiggå mera långsamt. Foten tillväxer i tjocklek på samma gång som buken, så att de blifva jemntjocka, i stället för att arkegoniet förut nedåt afsmalnade. Först sedan bukens lager och foten blifvit starkt utvecklade till en jemntjock cylinder, börjar äfven inuti centrum en lifligare celldelning, som utgår från centralblåsan och närmast afser bildandet af det ofta höga skaft (setan), hvarpå frukten uppbäres. Vid denna tid är ännu hela bukens väfnad mjuk, späd och hvitt ofärgad, visande en vacker färgbrytning mot den bruna eller violetta halsen. När sedan fruktskaftet börjar tillväxa starkare, upphör lifligheten i tillväxten af arkegoniets buklager, dess väfnad blir fastare och grönaktig. Då fruktskaftet sålunda tillväxer starkare inom arkegoniet, afsliter det vanligen dess af buken bildade väfnad. Den nedre, afslitna delen af buken samt foten qvarstanna i sammanhang med blomfästet och bilda en ringformig slida omkring fruktskaftets bas, den s. k. slidan eller vaginulan, på hvilken de afvissnade arkegonierna sitta. Hos de akrokarpiska mossorna, utom hos Cinclidotus, differentierar sig denna slida från fruktgrenen genom en skarp gräns och uppbär aldrig blad. Hos de pleurokarpiska mossorna finnes deremot ingen skarp gräns mellan slidan och fruktgrenen, utan öfvergå de omärkligt i hvarandra. Den öfre delen af bukens cellväf stannar deremot på den uppväxande setans topp och utväxer sedan till den för löfmossorna utmärkande mössan. Samtidigt med denna tillväxt af det befruktade arkegoniet utväxa vanligen äfven de inre, förut rudimentära hyllebladen och blifva större, än de yttre perigyn- eller perigambladen; de bilda sålunda det s. k. perichetiet, som omsluter setans bas. Perichetialbladens utveckling gör det lätt att äfven med blotta ögat se, att man har att göra med en befruktad blomma, redan innan setan börjar sticka ofvan dem. Hos en del akrokarpiska mossor, t. ex. hos Mnia, eger dock ingen sådan utveckling af perichetium rum. 
Det är vanligtvis vid den tid, då de befruktade arkegonierna uppsticka ofvan perichetiet, som deras cellväfnad hunnit till mera stadga, så att deras färg öfvergår från hvit till grön. Sedan arkegoniet antagit den fasta, gröna konsistensen, är det i allmänhet mera svårt att angifva dess relativa ålder. Det anger då endast, att befruktningen egt rum vid en mer eller mindre aflägsen, gången tidpunkt. Annu en månad efter befruktningen äro arkegonierna oftast hvita, men efter denna tid blifva de vanligen snart gröna. Hos några slägten visa sig de befruktade arkegonierna serdeles egendomliga, i det den sedan håriga mössans trichomer redan på de unga, befruktade arkegonierna börjat utveckla sig, såsom t. ex. hos Polytricha och Orthotricha.

De befruktade arkegonierna kunna ganska ofta felslå och afstanna då $i$ sin tillväxt. De kunna afstanna i alla sina utvecklingsstadier och blifva derigenom vilseledande vid blomningstidens bestämmande, om man ej märker, att de äro hämmade $\mathrm{i}$ sin utveckling. Stundom afstanna arkegonierna innan de hunnit höja sig öfver perichetiet, stundom äfven sedan setorna utvuxit till och med till hela sin längd och redan börjat kapselutvecklingen. I synnerhet äro i tillväxten hämmade arkegonier vanliga hos mossor, hos hvilka flera än ett arkegon i samma blomma kan befruktas och nå sin fulla utveckling. Flera arkegonieı kunna nemligen befruktas, än som mossan eger kraft att utveckla till frukter. Sålunda säga förff. af »Bryologia Europaea» om Mnium undulatum: »Oefter geschieht es auch, dass befruchtete Germina nicht zu ihrer völligen Entwicklung gelangen, nur bis über die Hüllblätter hervortreten und dann absterben. Solche unausgebildete Fruchtanfänge, die zwischen den vollkommenen Früchten vorkommen, können leicht zu den unrichtigen Ansicht führen, als trage ein und dasselbe Perichetium mehrere Jahre nach einander Früchte, besonders wenn selbige zwischen alten Kapselstielen stehend gefunden werden». Om också ofvannämnde hämmade arkegonier ej gerna kunna förleda någon att tro, det samma blomma skulle flera år efter hvarandra kunna frambringa för befruktning friska arkegonier, så äro de dock ganska vilseledande vid fråga om bestämmandet af blomningstiden. Andra exempel på hämmade arkegonier finuas äfven i »Bryologia Europaea» t. ex. på planscherna öfver Hypna exannulatum och stellatum. Ofta händer det äfven, att det enda i en blomma befruktade arkegoniet afstannar i sin tillväxt. Förf. har vid sina undersökningar af mossblommorna ofta funnit i tillväxten hämmade, befruktade arkegonier. 
För att nämna ett par exempel må anföras befruktade arkegonier, som knappt höjt sig öfver perichetiet, hos Hylocomium splendens från VG. $\frac{2}{6} 73$ och hos Hylocomium triquetrum från Ångml. $\frac{14}{6} 70$, under det att de $\mathrm{i}$ vanlig ordning utvecklade frukterna redan fälde eller hade fält sina lock.

Blomningstiden är för hvarje art bestämd och vanligen inskränkt till en mycket kort tid af året, oftast på ett och samma ställe inskränkt till blott en eller två veckor. Såsom ovanligt lång torde blomningstiden fa betraktas hos Webera albicans, hos hvilken förf. funnit, att hanblommorna en hel månad kunna visa svärmande antherozoider. $P_{a}^{\circ}$ exemplar af denna art från Angml. ${ }_{6}^{1574}$ hade antherozoiderna nyss börjat svärma och på ex. från samma ställe af den $\frac{1774}{7}$ funnos ännu några svärmande antherozoider qvar i de nästan tomma antheridierna. I allmänhet kan dock tiden för blomningen variera inom litet vidare gränser, än tiden för fruktmognaden. Det synes, som om under den långa fruktutvecklingen de skiljaktigheter i utvecklingen, som en varierande blomningstid förorsakar, något utjemnades, så att en varierande blomningstid ej ovilkorligen åtföljes af en lika mycket varierande tid för fruktmognaden.

En mera obestämd blomningstid visa sig några mossor hafva derigenom, att de ofta $\mathrm{i}$ sina blommor visa könsorganer $\mathrm{i}$ ganska olika utvecklingsstadier. I allmänhet äro alla könsorganerna lika mycket utvecklade i samma blomma. I »Bryologia Europaea» se vi dock på ett par ställen, att könsorganerna i samma blomma kunna vara mycket olikgamla. Salunda visar planschen öfver Racomitrium heterostichum III D exempel på en honblomma med olikgamla arkegonier; utom ett befruktadt arkegon finnes enligt denna plansch i samma blomma äfven öppna, obefruktade och unga, ej ännu halfvuxna arkegonier. Vid Bryum intermedium anmärkes $\mathrm{i}$ samma arbete såsom något egendomligt, att såväl antheridier som arkegonier kunna i samma blomma befinna sig $\mathrm{i}$ de mest olika utvecklingsstadier. Bland de i slutet af demna afhandling upptagna iakttagelserna kan läsaren finna många exempel på blommor med olikgamla könsorganer. Förf. vill blott påpeka några bland de mest egendomliga, t. ex. Tayloria serrata $\beta$ från Angml. $\frac{27}{9} 74$, Tetraphis från Vg. $\frac{8}{6} 73$, Bryum capillare från Gefle ${ }_{8} 70$ och Skåne $\frac{172}{8}$, Dissodon splachnoides från Ranen i Nordl., Orthotricha t. ex fastigiatum från Warnhem i VG. $\frac{4}{6} 73$ och Didymodon rubellus från Nordl. $\frac{2970 .}{7}$ Det är i synnerhet arkegonierna, som ofta visa sig olik- 
gamla i samma blomma. De samkönade blommornas könsorganer mogna vanligen samtidigt; endast sällan märkes hos dem någon tendens att öppna det ena könets organer före det andra könets. Hos Brya, t. ex. hos Brya inclinatum och bimum, synes dock en tendens till protogyni finnas, så att arkegonierna öppna sig före antheridierna. Finnes det något ändamål med denna anordning, eller är det blott en händelse, att så inträffat med de blommor, förf. undersökt? Vi hafva ej ännu bekant, huruvida hos mossorna sjelf befruktning eger rum, eller om befruktningen helst sker med hanorganer från ett annat individ, såsom hos fanerogamerna är vanligast. »Bryologia Europæa» synes vilja framhålla, att i samkönade blommor befruktningen eger rum mellan de i samma blomma befintliga könsorganerna. Den framhåller nemligen, att, då samkönade blommor felslå, så att de blifva rena honblommor, dessa aldrig blifva befruktade, samt att hos polygama arter aldrig eller sällan honblommorna blifva befruktade ${ }^{1}$. Är det $\mathrm{i}$ nämnda arbete framhålna faktum öfverensstämmande med verkligheten, hvilket förf. ej kan afgöra, så synes befruktning inom samma blomma kunna ske och till och med vara vanlig hos de hermafrodita mossorna.

Utom de löfmossor, som visa sig hafva en mera obestämd blomningstid derigenom, att könsorganerna i samma blomma äro olikgamla, finnes det äfven några löfmossor, som blomma hela eller större delen af sommaren. De mossor, som författaren funnit hafva den längsta blomningstiden äro: Hypna stellatum och uncinatum samt Amblystigium serpens, hvilka kunna blomma från midsommar till slutet af Augusti och således variera 2 månader; Pseudoleskea catenulata, hvilken blommar från början af Juni till slutet af Augusti och således kan variera 3 månader; samt slutligen Orthotricha, hvilka i detta afseende synas vara de regellösaste af alla mossor. Orthotricha blomma visserligen normalt på våren och försommaren, men de arter, som förf. haft tillfälle att undersöka i ett större antal exemplar, synas mycket ofta alstra blommor äfven p̊ andra tider. Mest varierande visade sig 0 . obtusifolium, som hade mogna blommor från början af Mars till slutet af Augusti, och 0 . speciosum, som visade mogna blommor från slutet af Maj till slutet af Augusti. Utom hos de ofvannämnda mossorna har förf. sällan funnit blomningstidens normala variation på samma ställe blifva större än en månad;

1) Jfr Bryol. Eur. vid Mnium serratum, Bryum pendulum m. fl. Brya. 
så stor har den dock visat sig hos några, t. ex. hos Pylaisia, Leskea nervosa, Meesia uliginosa och Leptobryum.

Ofta händer det äfven, att de andra löfmossorna, hvilka hafva en bestämd och kort blomningstid, stundom helt abnormt utom den egentliga blomningstiden alstra blommor. Isynnerhet är detta ofta fallet hos de pleurokarpiska. Hos dessa mossor äro dock hanblommorna ej vanligare på abnorma tider, än honblommorna, såsom D:r Klinggräff säger i Bot. Zeit. 1860, sid. 345. Hans antagande, att hanblommorna oftare utveckla sig på abnorma tider, grundar sig tydligen pa hans okunnighet om den långa tid, som hanblommorna behöfva för sin utveckling. Då han sett hanblommor med fullt utvecklade antheridier ofta flera månader före den egentliga blomningstiden, har han ej anat, att dessa först efter lång tid skulle blifva mogna, utan ansett dem såsom utvecklade och blommande på abnorma tider. Såsom exempel på, huru konstanta vanligen äfven hanblommorna äro i sin mognad, må anföras, att den största funna variationen hos t. ex. Hylocomia inskränker sig till en månad, eller från midsommar till slutet af Juli hos Hylocomium splendens. Dock finnas ibland på abnorma tider mogna hanblommor, men minst lika ofta honblommor. Exempel på utom den vanliga tiden blommande honblommor lemna t. ex. de unga honblommorna hos Hypnum Schreberi och Brachythecium reflexum från Ner. $\frac{6}{4} 73$, och hos Brachythecium albicans från Ner. y $73 \mathrm{~m}$. fl. Ibland de pleurokarpiska mossorna äro dock Neckerae mest utmärkta för sin förmåga att hela sommaren alstra blommor äfven utom den vanliga blomningstiden. Neckera oligocarpa är isynnerhet häruti laglös, hvarigenom äfven dess normala blomningstid blir mycket svår att bestämma. Neckera-arterna synas härigenom ofta utveckla blommor acropetalt på samma årsskott, hvilket är ovanligt hos de pleurokarpiska mossorna, hvilka vanligen på samma årsskott utveckla alla blommor af samma kön liktidigt.

Ibland de akrokarpiska mossorna äro i allmänhet utom den rätta blomningstiden utvecklade blommor ovanligare. Exempel på sådana blommor lemna dock honblommorna hos Fissidens adianthoides från VG $\frac{9}{6} 73$, hos Fiss. osmundioides från Sk. $\frac{1173}{6} 73$ och hos Pogonatum alpinum från Ångml. $\frac{3}{8} 73 \mathrm{~m}$. fl. Dessutom äro isynnerhet Orthotricha, såsom vi redan omnämnt, regellösa, och de med dem till förgreningen likartade Ecalyptae visa äfven ofta blommor på abnorma tider. Racomitria och Grimmiae torde äfven ofta blomma på abnorma tider, om man får sluta 
från de hos dem ofta förekommande oregelbundenheterna i fråga om tiden för fruktmognaden.

Vanligen blommar samma mossa på samma tid af året inom hela Skandinavien, så att, om t. ex. en mossa blommar under löfsprickningen i Skåne, den äfven blommar under löfsprickningen $\mathrm{i}$ de nordligare delarne af Skandinavien o. s. v. Nagra löfmossor visa sig dock afvikande från ofvannämnda regel och blomma i olika delar af Skandinavien på olika tider af året. Härvid eger den egendom'igheten rum, att de flesta af dessa mossor blomma tidigare på Norges vestkust uppe i Nordlanden, än i Sverige. Blott en enda blommar i det nordligare Skandinavien vid en senare tid af året, än $i$ den sydligare delen af Sverige.

Under en tidigare period, än i Sverige, blomma i nordliga Norge följande mossor:

Plagiothecia piliferum och Mühlenbeckii, hvilka i Nordlanden samt i Trondhjems stift blomma i början och midten af Juli, i Ångml. deremot mest $i$ slutet af Augusti och början af Sept.

Catharinea tenella, som vid Suul i Vaerdalen af Trondhjems stift blommade den $\frac{26}{6} 70$ på öfver 1000 fots höjd öfver hafvet, motsvarande ungefär början och midten af Juni vid hafsytan. I Ångml. blommar den först i senare hälften af Juli.

Leptotrichum glaucescens, som blommar i Nordlanden midsommartiden, i Angml. omkring den 1 Augusti.

Cynodontia virens och Wahlenbergii, som blomma i Nordlanden samtidigt med förutnämnda Dicrana, i Ångml. deremot vid midsommartiden efter slutad löfsprickning.

Dicrana, t. ex. D. fuscescens och elongatum, och troligen alla de i Ångml. i senare hälften af Juli blommande arterna, blomma i Nordlanden i början af Juni, före eller möjligen vid början af löfsprickningen. Förf. har dock ej haft tillfälle att undersöka exemplar af Dicr. elongatum från Svenska låglandet, men antagligen blommar äfven denna art i Sverige samtidigt med de närbeslägtade Dicrana i slutet af Juli. Enligt Bryol. Eur. blomma dessa Dicrana i mellersta Europa på senhösten och våren. På detta sätt synes blomningstiden åtminstone delvis, eller om våren, infalla på samma årstid i södra Europa och i Nordlanden, hvaremot blomningstiden är helt olika i det mellanliggande Sverige.

Under en senare årstid blommar deremot på en nordligare lokal Hypnum fastigiatum, hvilken i nordliga Skandinavien, t. ex. i Nordlanden och Österbotten, blommar i midten och slutet 
af Augusti, i Nerike deremot synes blomma samtidigt med Hypnum cupressiforme straxt före och under löfsprickningen.

Ingen löfmossa blommar, så vidt förf. känner, 2 gånger på året. Fruktsätta Brya Warneum och calophyllum 2 gånger på året, torde de äfven blomma 2 gånger. Förf. har dock ej varit i tillfälle att undersöka, om så är fallet.

Det kunde slutligen kanhända synas vid betraktandet af det ringa antal ibland iakttagelser, som på somliga arters blommor blifvit gjorda, eller af den totala bristen på iakttagelser vid några andra arter, som om förf. alltför lättsinnigt dragit sina slutsatser om tiden för blomningen hos löfmossorna. För att bemöta en sådan anmärkning får förf. omnämna, att han ej uteslutande från blommorna dragit sina slutledningar om blomningstiden. Unga, uppstickande setor eller unga frukter, likartad lockfällningstid hos närslägtade arter $\mathrm{m}$. fl. omständigheter hafva jemsides med blommorna varit behjelpliga vid finnandet af blomningstiden för de serskilda arterna. Att man likväl ej från en lika fruktsättningstid får obetingadt sluta till en lika blomningstid, visa flera exempel $i$ det följande kalendariet. Helt oväntade olikheter visa sig nemligen ofta i fråga om blomningstiden, der man på grund af lika lockfällningstid minst kunde ana det, hvarpå bland andra Eurhynchia, Dicranellae och Leptotricha lemna exempel. Alla Eurhynchia fälla locken nästan samtidigt straxt före löfsprickningen. Två arter, Eurh. strigosum och diversifolium, blomma samtidigt med lockfällningen, alla de öfriga blomma först öfver 2 månader efter densamma. Bland Dicranellae, som äfven fälla locken sinsemellan samtidigt, blomma de flesta $i$ slutet af Juni och använda $6-8$ månader på frukutvecklingen, hvaremot 4 arter blomma omkring den 1 September och använda $16-18$ månader på fruktens utveckling. Leptotrichum tortile $\beta$ på ena sidan och Lept. homomallum och pallidum på den andra visa likadana skiljaktigheter, som Dicranellae. Slägtet Leptotrichum är dessutom mycket intressant, emedan man inom detsamma kan hemta goda karakterer, som äro ganska lätta att konstatera, för att skilja alla arterna från hvarandra ifrån de för de olika arterna olika tiderna för blomningen eller fruktmognaden, såsom det lätt synes vid de $\mathrm{i}$ slutet af denna afhandling intagna special-observationerna. 


\section{Fruktmognad.}

Löfmossornas frukter äro mera i ögonen fallande, än deras blommor, och derigenom inverka de äfven vid sitt uppträdande mera på mossvegetationens olika utseende under årets olika tider. De hafva äfven derföre blifvit mera uppmärksammade, än blommorna. Under det att löfmossornas blomningstid hittills varit i de flesta fall helt och hållet obekant, finnas i hvarje speciel bearbetning af denna växtgrupp uppgifter om tiden för de serskilda arternas fruktmognad.

Hos största delen af löfmossorna utmärkes fruktmognaden derigenom, att vid tiden för sporernas mognad fruktens lock affaller, och frukien visar i dagen sin vanligen med 16 tänder besatta mynning. Fruktmognaden utmärkes således hos flertalet af löfmossorna (Musci stegocarpi) genom lockfällning. Hos de lägsta formerna af flera akrokarpiska mossfamiljer finnas locken endast antydda, men kunna ej fällas, eller ock äro de hos några ej ens antydda. Hos dessa mossor affaller hela frukten oöppnad vid fruktmognaden, och kallas de derföre » Musci cleistocarpis. De kleistokarpa mossorna fördes fordom till ett gemensamt slägte Phascum L., men nu har detta af högst olikartade elementer bestående slägte blifvit sönderklufvet i flera smärre slägten, hvilka insystimatiserats $\mathrm{i}$ närheten af sina närmaste slägtingar bland de stegokarpa mossorna. Hos familjen Andraeaceae eger ej heller vid fruktmognaden någon lockfällning rum, utan uppspringer hos denna familj frukten i vanligen 4 valvler, hvilka i spetsen sammanhänga med kolumellan. Dessa mossor kallas af denna anledning Musci schizocarpi».

För efterföljande kalendarium har förf. studerat tiden för löfmossornas fruktmognad, hvilken utmärkes genom lockfällning, hela den oöppnade fruktens affallande eller genom fruktens uppsprickande i 4 valvler, dels uti naturen, dels äfven uti herbarier. Endast i några fall, då förf. ej haft tillräckligt material för att bilda sig en egen åsigt angående tiden för fruktmognaden, har han med uttryckligt angifvande deraf stödt sig uteslutande på andras uppgifter. De arbeten, hvarifrån förf. då hemtat sina uppgifter äro förnämligast: »Skandinaviens Flora» af C. Hartman, «Bryologia Europaea» af Bruch, Schimper och Gümbel, >Synopsis muscorum Eur.» af W. P. Schimper och »Bryologia Si- 
lesiaca af J. Milde. Det kunde synas onödigt att serskildt studera tiden för fruktmognaden, då uppgifter derom finnas i hvarje mossflora. Dessa uppgifter hafva dock så ofta visat sig origtiga, att förf. ej kunnat sätta förtroende till dem. För att styrka sitt påstående, att de redan förefintliga uppgifterna ofta äro origtiga och derigenom blifva otillförlitliga, vill förf. ingå på en kritik af de uppgifter, som finnas angående tiden för fruktmognaden i de 4 ofvannämnda mossflororna, hvilkas uppgifter väl skulle vara upplysande äfven för våra Skandinaviska förhållanden.

Vända vi oss då först till »Skandinaviens Flora», hvilken väl närmast borde lemna uppgifter, som passa in på våra Skandinaviska förhållanden, så skola vi finna, att uppgifterna om fruktmognadstiden ej blifvit gjorda med den stora samvetsgrannhet, hvarför detta arbete i alla andra afseenden är så framstående. Uppgifterna äro uttryckta med månadernas ordningsnummer och utmärka, »när frukten mognar». Det är svårt att med kalendermånader angifva tiden, så att den slår in för hela Skandinavien, då det är fråga om företeelser, som äro bundna vid bestämda årstider. Skandinavien har så stor utsträckning i bredd, omkring $151 / 2$ grader, att $\mathrm{i}$ synnerhet våren och hösten infalla mycket oliktidigt i olika delar af området. Sålunda är det nästan 2 månaders skilnad i tid mellan häggens blomning i Skåne och Haparanda. Om man med månader skall angifva tiden för mossornas vid bestämda årstider bundna fruktmognad, så måste en ganska vidsträckt tidrymd angifvas, om uppgifterna skola blifva gällande för hela Skandinavien. Dock kunde man kanske slippa ifrån dessa uppgifter, som ofta skulle omfatta en vidsträckt tidrymd, genom att för de mossor, som äro utbredda öfver hela Skandinavien, angifva medeltiden, eller den tid, då de fruktsätta i dess mellersta del. I »Skandinaviens Flora» äro uppgifterna äfven ofta tilltagna på bredden, men då ofta allt för mycket, såsom det t. ex. synes af de härnedan anförda uppgifterna om tiden för fruktmognaden hos Hylocomia. Äro tiderna mera bestämdt och kort angifna, hafva de alltför ofta afseende på förhållandena i sydliga Sverige, ej på medelförhållandet i hela Skandinavien, hvilket äfven är ett genomgående fel i samma floras fanerogam-del. För att beteckna tiden för vid bestämda årstider bundna företeelser i naturen vore det väl lättast och naturligast att begagna den tidräkning, som naturen sjelf gifver oss genom de olika årstiderna. Genom ett sådant förfaringssätt undviker man äfven oftast de misstag, som man eljest lätt begår. 
För att visa, att äfren många andra felaktigheter finnas bland uppgifterna i »Skandinaviens Flora», än de, som härflutit från begagnandet af beteckningssättet med månader, får förf. hänvisa till några större slägten, inom hvart och ett af hvilka frukterna mogna nästan samtidigt, hvilket dock ej kan synas af nämnda arbete, emedan uppgifterna derstädes oftast äro helt olika för de olika arterna. Sålunda mogna hos Hylocomia frukterna och fällas locken nästan samtidigt hos alla arterna på våren från början af Mars till in i Juni, allt efter olika breddgrader. Hos Hylocomium splendens fällas de från slutet af April i Skåne, till omkring den 1:ste Juli i nordliga Skandinavien. I $\mathrm{\&}$ Skandinaviens Flora» äro uppgifterna följande: Hyloc. splendens 4-8, H. umbratum 9-5; $\mathrm{H}$. Oakesii 9,$10 ; \mathrm{H}$. brevirostre 8,9 ; $\mathrm{H}$. triquetrum $4-9 ; \mathrm{H}$. loreum $9-4$; H. sqarrosum $5-9$; H. subpinnatum 9,10 . Uppgifterna äro således för nästan alla arterna olika. Brachythecia, Eurhyncia, Polytricha, Grimmiae, Dicranellae m. fl. slägten, inom hvilka alla arterna nästan samtidigt få mogna frukter, kunna lemna vidare exempel på den brist på konsequens och noggrannhet $\mathrm{i}$ uppgifterna om tiden för fruktmognaden, som förefinnes $\mathbf{i}$ detta arbete. Ej sällan uppgifvas äfven tider, då frukterna äro som mest förvissnade, eller då knappt annat, än unga fruktskaft finnes, såsom t. ex. vid uppgifterna om Dicranellae heteromalla och subulata 5-9, Brachythecium salebrosum 7-9, Tortula subulata $4-5$, Racomitrium microcarpum $7-8 \mathrm{~m}$. fl. Ett i högsta grad vilseledande sätt att beteckna tiden för fruktmognaden är det slutligen att angifva två tider för samma art, hvilket ganska ofta förekommer i denna flora, såsom t. ex. vid Brachythecium Starkei 4, 5; 8, 9; Br. populeum 4, 5; 8, 9; Eurhynchium striatum 5,$6 ; 8,9$; Thamnium $4-6 ; 8,9$ m. fl. Igenom detta beteckningssätt föranledes lätt nybörjaren att tro, det dessa mossor fruktsätta 2 gånger om året, och hafva vi äfven blifvit tillfrågade på grund af dessa uppgifter, om ej detta verkligen vore fallet. Då detta vilseledande beteckningssätt blifvit begagnadt, är det för en del af de talrika mossor, som redan på hösten träffas med fullformade, vackra frukter, men möjligen under vintern, vanligen först tidigt på våren fälla sina lock. Det har ej ens användts konsequent för alla $\mathrm{i}$ detta afseende likartade mossor.

»Bryologia Europaea» och »Synopsis muscorum» angifva genom sina titlar, att de hafva afseende på hela Europa, och, då i allmänhet intet serskildt blifvit anmärkt vid uppgifterna om ti- 
den för fruktmognaden, så har man rätt att vänta, att äfven de skulle vara giltiga för hela Europa. Så är dock i allmänhet ej fallet; uppgifterna synas nemligen mest afse förhållandena i mellersta Europa. Endast högst sällan är afseende fästadt på de olikheter, som olika breddgrader i fråga om tiden för fruktmognaden kunna förorsaka, litet oftare, fast sällan, fästas afseende på höjden öfver hafvet.

$\mathrm{P} ̊$ breddgraden är i synnerhet sällan afseende fästadt. Ett undantag visar dock Trichostomum crispulum, för hvilken Bryol. Eur. uppgifver »maturatio: in Sardinia vere, prope Argentoratum Juni, prope Grindenwald Augusto», och Synopsis muscorum: » vere in Europa meridionali, Juni et Juli ad Rhenum et in Helvetia». Genom sådana uppgifter skulle vi, om de vore tillförlitliga, noggranna och talrika, kunna följa årstidernas fram- och återtågande i Europa. Ofvanstående uppgifter äro dock ensamt stående i dessa arbeten. Äfven vid ett par andra Skandinaviska mossor är afseende fästadt på bredden, i det att det vid Grimmiae Mühlenheckii och commutata i Bryol. Eur. står, att de få mogna frukter i Skandinavien »auctumno», hvilka uppgifter dock äro origtiga, emedan de hos oss fruktsätta på våren. En och annan gång omtalas äfven, fast sällan, tiden för fruktmognaden »in regionibus septentrionalibus».

Långt oftare har i de båda ofvannämnda flororna afseende fästats på det inflytande, som höjden öfver hafvet utöfvar, genom uttrycken »in alpibus» och »in alpinis». Ett fel har dock härvid ofta blifvit begånget, i det att, då årstider blifvit begagnade, för att angifva tiden för fruktmognaden, förff. ej angifvit den årstid, som verkligen herrskar på den höjd, hvarpå mossorna växa, utan den årstid, som nere $i$ låglandet är samtidigt dermed rådande. Så mogna frukterna t. ex. hos Mnium orthorrhynchum enligt Bryol. Eur. »vere, in alpinis ad aestatis finem», hos $\mathrm{Cy}-$ nodontium virens enligt Synopsis muscorum initio aestatis, in alp. editioribus versus finem». Om det också är nästan slut på sommaren i låglandet vid fjällens fot, när ofvannämnda mossor sätta frukt högt uppe öfver låglandet, så är det ju ej derför nära slut på sommaren deruppe, hvilket just bevisas derigenom, att vårens och försommarens mossor der ej ännu afslutat sin lockfällning. Såsom ett vidare exempel på sådana vilseledande uppgifter må anföras Trichostomum rigidulum, hvilken fruktsätter enligt Bryol. Eur. »auctumno et hyeme, in alpibus aestate», och enligt Synopsis muscorum 》primo vere, in subalpinis aestates. 
Äfven vid många andra löfmossor finna vi liknande vilseledande uppgifter.

Derigenom, att förff. af dessa arbeten ej betänkt, att våren framskjutes allt längre, ju högre upp på fjällen vi komma, hafva äfven en del fjällarter, som äro tydliga vårmossor likt, de närslägtade arterna, angifvits sätta mogna frukter om sommaren, emedan de på sin höga växtlokal fruktsätta liktidigt med sommaren i låglandet. Exempel härpå lemna uppgifterna om fruktmognadstiden vid Brachythecium collinum »aestate» i Bryol. Eur. \& Syn., Brach. glaciale » ad aestatis finem» i Syn., Grimmia mollis s aestate i Bryol. Eur. \& Syn., Webera Ludwigii »aestate» i Syn., Ångströmia » aestate» i Syn., och » aestate» enligt Bryol. Eur. vid alla Andraea-arterna, utom vid A. rupestris, för hvilken tiden står s vere et aestate». Att dessa mossor, om de någon gång förirra sig ned till låglandet, fruktsätta om våren samtidigt med sina samslägtingar, visar sig t. ex. af Webera Ludwigii, hvilken förf. i Nordlanden fann nära nog $\mathrm{i}$ hafvets niveau. Den visade sig nemligen der den $1 \frac{9}{7} 70$ hafva affallna lock och vara lika långt kommen i utveckling, som den närslägtade och bredvid växande Webera pulchella. För Hypnum molle angifves likaledes i Bryol. Eur. fruktmognaden inträffa »ad aestatis finem», ehuru denna mossa, då den i mellersta Skandinavien nedgår till låglandet, fäller locken omkring midsommar. Förf. får dock i sammanhang med dessa anmärkningar omnämna, att ett ombyte af årstid eller en framflyttning till en senare årstid af fruktmognaden troligen ofta eger rum vid en större höjd öfver hafvet, så att kanske en del af de uppgifter, som framflytta fruktmognaden till en senare årstid i fjällen, äro öfverensstämmande med verkliga förhållandet. $\mathrm{Vi}$ skola nemligen $\mathrm{i}$ det följande se, att en framflyttning af fruktmognaden till en senare årstid ofta eger rum åtminstone vid en nordligare breddgrad. I analogi härmed torde äfven t. ex. följande uppgifter ega sin rigtighet, nemligen att frukterna mogna enligt Bryol. Eur. hos Tortula tortuosa »vere, in editioribus versus aestatis finem》 och hos Trichodon s vere, in alpinis aestate». Atminstone eger hos dessa mossor mot norden en sådan framflyttning af fruktmognaden rum, att de i Skandinavien ej fruktsätta på våren, utan under sommaren.

Betrakta vi åter de allmänna uppgifterna, vid hvilka ej fästats afseende på breddgrader eller höjd öfver hafvet, så äro de oftare gjorda genom angifvande af årstiderna, än af månaderna för fruktmognaden. Beteckningssättet genom årstider visar sig 
här äfven hafva ett afgjordt företräde framför månadsuppgifterna. Är det redan svårt och förenadt med större arbete att medelst månader noggrant angifva tider för fruktmognaden, som äro giltiga för hela Skandinavien, så måste det vara ännu svårare, om de skola vara giltiga för hela Europa. Månadsuppgifterna i dessa arbeten sammanstämma derför mycket ofta ej med våra förhållanden. Uppgifterna medelst årstider äro i allmänhet mera öfverensstämmande med förhållandena i Skandinavien. Den ofvan antydda omständigheten, att vid en nordligare breddgrad fruktmognaden ofta framflyttas till en annan årstid, gör dock, att äfven många uppgifter medelst årstider ej passa för vårt nordliga land.

Isynnerhet framflyttas sålunda fruktmognaden hos de mossor, som i södra och mellersta Europa fälla locken på hösten eller under barvintrarne derstädes. I Skandinavien täcker snön alltid marken under vintern, åtminstone $\mathrm{i}$ de mellersta och nordliga delarne. Härigenom infaller då ett stillestånd i mossornas utveckling, så att locken ej kunna fällas. Först på våren efter snöns försvinuande kunna dessa mossor här fälla sina lock och utså sina sporer. Såsom exempel på mossor, som sålunda i Skandinavien få fruktmognaden framflyttad från senhösten till våren, må följande nämnas, som i Bryol. Eur., Synopsis muscorum och Bryologia Silesiaca enstämmigt angifvas fälla locken på hösten i mellersta Europa: Hylocomia t. ex. umbratum, Hypnum Schreberi, Brachythecia glareosum, salebrosum, reflexum, Starkei och populeum, Eurhynchia praelongum, Stokesii, striatum och strigosum, Homalothecium, Climacium, Homalia, Anomodon-arterna, en del Fissidens-arter m. fl.

På samma sätt få äfven en del, i sydliga och mellersta Europa till våren och försommaren hörande mossor, uti Skandinavien lockfällningen framflyttad till efter midsommaren. Sålunda angifvas i de 3 ofvannämnda flororna enstämmigt följande mossor fruktsätta på våren, nemligen Pterigynandrum, Leskea polycarpa, Gymnocybe palustris (dock »Sommer» enligt Milde), Philonotis fontana, Bryum eapillare, Leptobryum, Physcomitrium m. fl., hvilka alla i Skandinavien oftast först temligen långt efter midsommar fälla sina lock. Äfven några mossor, för hvilka fruktmognadstiden blifvit angifven medelst månader, visa, att en framflyttning till efter midsommaren af södra och mellersta Europas vår- och försommar-mossor hos oss eger rum. Sålunda angifves Hypnum incurvatum för Maj, Paludella 
och Aulacomnium androgynam för Juni, Tortula muralis för April och Maj, o. s. v.; af dessa fruktsätta de 3 första i Skandinavien först omkring den 1 Augusti; Tortula muralis är ganska varierande, men dess normala lockfällningstid infaller i Skandinavien först efter början af Juli.

I det föregående har förf. visat, att i de 2 nu på tal varande arbetena uppgifterna om tiden för fruktmognaden ofta ej äro för våra Skandinaviska förhållanden upplysande, emedan i dessa arbeten ej vederbörligt afseende fästats på de olika breddgraderna och höjden öfver hafvet, och emedan största delen af uppgifterna närmast hafva afseende på långt sydligare trakter. Då äfven många uppenbart felaktiga uppgifter i dem finnas, förminskas härigenom ännu mera deras användbarhet med någon tillförsigt.

"Bryologia Silesiaca» af D:r J. Milde lemnar uppgifter, som afse förhållandena i våra sydliga grannländer. Om tillbörligt afseende fästes derpå, att uppgifterna äro gjorda för något sydligare breddgrader, så äro de goda häntydare på tiden för fruktmognaden äfven hos oss och användbara för att kontrollera rigtigheten af de resultater, hvartill man kommit angående tiden för fruktmognaden i Skandinavien. Uppgifterna i denna flora äro $i$ allmänhet noggranna; årstider eller månader äro ungefär lika ofta använda för att beteckna tiden. Området för denna flora är jemförelsevis i fråga om bredden litet; bredden är endast hälften så stor, som Skandinaviens, eller litet öfver 7 grader. Härigenom kunna äfven månadsuppgifterna lättare och med mindre fara för misstag begagnas, ty hvarje serskild arts fruktmognad infaller nästan samtidigt inom hela området. Ett fel, som mycket oftare återkommer i denna flora, än i »Bryologia Europaea» och »Synopsis muscorum», är det, att uppgifter helt och hållet blifvit utelemnade. En del fel finnas dock nog äfven här, såsom t. ex. uppgifterna att Dicranellae subulata och cerviculata, Fissidens osmundioides samt Racomitrium patens skulle sätta frukt på sommaren.

Jemföra vi slutligen uppgifterna vid en del löfmossor i de fyra ofvannämnda flororna sinsemellan och med de resultater, hvartill förf. kommit, skola vi finna, att stundom en ganska egendomlig olikhet i uppgifterna förefinnes. Såsom förkortningar har förf. vid denna jemförelse användt B. S. för »Bryologia Europaea», Syn. för »Synopsis muscorum», M. för »Bryologia Silesiaca och $\mathrm{Hn}$ för »Skandinaviens Flora». Sålunda fruktsätta: 
Plagiothecium denticulatum $\gg$ aestate B. S.; > vere et aestate, in alp. auctumno» Syn.; $» 5-8 \mathrm{Hn}$; enligt förf:s erfarenhet deremot under skördetiden och löffällningen.

Catharinea tenella » Aug. et Sept.» B. S.; »auctumno» Syn.; >9, 10 $\mathrm{Hn}$; » Sommer» M.; enligt förf. om vintern.

Amphoridium lapponicum »Sept.» B. S.; »aestate Syn.; >5-7» Hn; »Mai» M.; enligt förf. under löfsprickningen.

Grimmia ovata »aestate» B. S.; »ad aestatis finem» Syn.; >6-9» Hn; »Herbst» M.; enligt förf. vid löfsprickningens början.

Grimmia unicolor »aestate» B. S.; »auctumno» Syn.; 6,7 » $\mathrm{Hn}$; Herbst» M.; enligt förf. liktidigt med den föregående.

Dicranella heteromalla »primo vere» B. S. och Syn.; $\$ 5-9$ » $\mathrm{Hn}$; Spätherbst und Frühling» M.; under vintern enligt förf.

Dicranella subulata »Augusto» B. S.; »Septembri» Syn.; >5-9 $\mathrm{Hn}$; » Sommer» M.; under vintern enligt förf.

Dicranella cerviculata »Junio et Julio» B. S.; »aestate» Syn.; ๑ 7-9» Hn; »Sommer» M.; under vintern enligt förf.

Fissideus osmundioides vere B. S.; » aestate» Syn.; $6-8$ » $\mathrm{Hn}$; Sommer M.; under sidvintern enligt förf. o. s. v.

Vid bestämmandet af tiden för fruktmognaden äro en del omständigheter att ihågkomma, hvilka kunna dervid vilseleda. Vid begagnandet af herbarier för bestämmandet af denna tid är det nödigt att ihågkomma, att vid pressning lockfällningen påskyndas. Temligen unga frukter kunna derför fälla alla locken vid pressning, ehuru dessa sutto qvar vid insamlingen. Detta förhållande är så bekant för hvar och en, som insamlat löfmossor, att det knappt kunde behöfva belysas med några exempel. Förf. vill blott anföra det enda yttrande om denna sak, som han sett, och som finnes i Bryol. Eur. vid Oligotrichum hercynicum, om hvilken det står: „Selbst bei unreif gesammelten Früchten fällt der Deckel beim Austrocknen schon zugleich mit der Haube ab, so dass man nur höchst selten in einer Sammlung eine reife mit ihrem Deckel versehene Kapsel antrifft.» $\mathrm{Om}$ man derföre efter herbarie-exemplar vill angifva en naturlig och ej en med konst frambragt lockfällningstid, måste man något framflytta den genom dem utvisade tiden. Tagas exemplareu på mycket torra och solbrända ställen, och lockfällningen dertill påskyndas genom pressning, så kunna mossor fälla sina lock långt före den normala tiden, och genom sådana exemplar vilseledande åsigter om fruktmognadstiden bibringas. Så t. ex. började Ceratodon purpureus att fälla locken 
vid pressning på exemplar, som insamlades den $\frac{6}{6} 74$ i Ångml. på en mycket solbränd lokal mot söder, under det att samma sommar lockfällningen under vanliga förhållanden ute i naturen inföll allmänt först en månad senare.

$\AA$ andra sidan kan man förledas att framskjuta fruktmognadstiden hos en del löfmossor alltför långt. Sålunda qvarsitta locken hos några ganska länge efter fruktmognaden, emedan de äro fastruxna med kolumellan, som är ovanligt lång och varaktig, såsom hos Climacium, Pottia Heimii och Gymnostomum curvirostre. Äfven hos Cinclidia qvarsitta locken ofta efter fruktmognaden sammanvuxna med och uppburna på det hvalflika, inre peristomet. Genom lockens qvarvarande kan man lätt föranledas att tro, det lockfällningen hos dessa mossor pågår, och att frukterna just äro mogna, fastän ganska lång tid kan hafva sedan dess förflutit.

Mera vilseledande äro dock en del löfmossor, hos hvilka man ofta långt efter fruktmoguaden finner locken och ibland äfven mössorna sitta qvar på grund af någon oförmåga hos frukterna att fälla desamma. Detta förhållande är inom en del slägten mera vanligt, än inom andra, dock mest blott hos enstaka frukter, ej hos alla. Sålunda förekommer det ofta hos Orthotricha, Grimmiae, Racomitria, Brachythecia och Hylocomia. Hos Orthotrichum rupestre funnos t. ex. mössor qvar i Ångml. 1974 och hos 0 . speciosum funnos mössor qvar större delen af sommaren 1874 i Ångml. Vid aftagandet af mössorna följde dock locken med, och frukterna hade utseende af att vara öfvermogna och vissnade. Samma förbållande har förf. äfven sett hos flera andra Orthotricha, t. ex. hos 0 . Sturmii och cupulatum, långt efter den normala lockfällningstiden. Hos Grimmia Mühlenbeckii funnos på samma sätt i Ångml. $\frac{2}{7} 74$ och i Mdpd $2 \frac{1}{7} 74$ en del lock qvar, likaså hos Racomitrium microcarpum i Angml. 1774, hos Brachythecium velutinum i Ångml. ${ }_{8}^{4} 68$ och i Sk. ${ }_{8} 68$, hos Hylocomium subpinnatum vid Gefle ${ }_{10} 73$ o. s. v. Locken affalla aldrig hos dessa frukter, utan affalla slutligen kapslarne oöppnade, såsom hos de kleistokarpa mossorna. Hos Orthotricha och Grimmiae äro troligen isynnerhet de starka temperaturvexlingar, hvarför frukterua under vintern äro utsatta, och som kanske inverka störande på lifsverksamheten $\mathrm{i}$ de under denna årstid unga frukterna, orsaken till denna oförmåga att afkasta locken. Genom sin växtlokal på klippor och träd, som ej täckas af ett skyddande snötäcke, blifva nemligen dessa mossor mera utsatta 
för temperaturvexlingarna under vintern, än de på marken växande mossorna, hvarför detta förhållande äfven hos dem är vanligast.

En egendomlig orsak till lockfällningens fördröjande finnes stundom, isynnerhet ofta hos Mnium hornum, i det att den ensidiga mössan ej uppspringer vid basen. Den tillväxande frukten hindras i sin tillväxt inom mössans fängelse både upptill och nedtill. Slutligen böjes frukten och spränger på sidan upp mössan, hvilken sålunda uppristas, tills hålet blir så stort, att frukten kan slippa ut genom öppningen. Härigenom har dock frukten blifvit sned ifrån att normalt vara symmetrisk. Mössan qvarsitter sedan på fruktskaftet nedom frukten ${ }^{1}$ ).

Ofta har man ej mogna frukter att tillgå, utan måste sluta från unga eller gamla frukter till tiden för fruktmognaden. Vid begagnandet af de gamla frukterna måste man då ihågkomma de olikheter, som förefinnas hos olika mossor i afseende på längden af den tid, under hvilken frukten qvarsitter på moderväxten, och på den olika hastighet, hvarmed frukterna förvissna. I allmänhet qvarsitta frukterna på moderväxten vid fruktmognaden. Endast hos Octodiceras, hvilken dock ej blifvit funnen med frukt i Skandinavien, lossnar frukten före mognaden från moderväxten och simmar fri med mössa och lock omkring på vattuet, hvari denua mossa växer ${ }^{2}$ ). Hos de kleistokarpa mossorna affalla frukterna vid fruktmognaden. Alla de öfriga löfmossornas frukter qvarsitta längre eller kortare tid efter spormognaden. En del Dicrana, t. ex. D. scoparium, äro isynnerhet utmärkta för de länge qvarsittande och till utseendet friska frukterna. Hos de flesta af slägtets arter qvarsitta dessa ofta mera än ett år efter lockfällningen; hos några $f_{a}^{\circ}$ arter, t. ex. hos Dicranum spurium, afvissna de deremot ganska fort. Äfven många andra löfmossor hafva ofta de gamla frukterna qvarsittande ett helt år efter lockfällningen, så att de finnas qvar ännu vid nästa fruktgenerations mognad. Exempel härpå lemna Hylocomia, Hypna Halleri, Schreberi, Crista castrensis, uncinatum (olikt de öfriga Harpidia), Plagiothecia, Polytricha, Trichostomum glaucescens m. fl. Endast i undantagsfall förmultnar dock frukten, medan den ännu qvarsitter på moderväxten, såsom t. ex. hos Arctoa fulvella; vanligen affaller den med en större eller mindre del af skaftet, innan den börjar förmultna. Finnas äfven locken

1) Liknande fall finnas i Bryol. Eur. aftecknade vid Catoscopium nigritum, Discelium nudum m. fl.

${ }^{2}$ ) Jfr Bryol. Eur. vid Octodiceras. 
qvar på de qvarsittande frukterna, såsom stundom kan inträffa, så kan man lätt blifva vilseledd till att antaga en oriktig lockfällningstid. Hos andra löfmossor affalla deremot frukterna så fort, att de alltid hafva försvunnit långt före nästa fruktgenerations mognad, t. ex. hos sump-Hypna och Mnia. Utmärkta för snart förvissnade och till utseendet åldriga frukter äro många af de mindre, isynnerhet de enåriga, jordmossorna, t. ex. Weberae, Discelium, Pottiae, dessutom äfven andra löfmossor t. ex. Mnia och Splachna, hos hvilka alla frukterna så snart antaga ett åldrigt utseende, att intet tvifvel om deras ålder kan uppstå.

Fruktmognadstiden är vanligen mycket noga bestämd, och hos de flesta löfmossor varierar den på samma ställe sällan öfver en vecka. Isynnerhet äro de lockfällande mossorna i detta afseende utmärkta. Lockfällningen inträffar hos de flesta så liktidigt på alla individer inom samma trakt, erfordrar vanligen så kort tid och är så lätt att iakttaga ute i naturen, att den, om mosskännedomen vore mera spridd, skulle vara ännu lämpligare, än de andra fenomener, hvaraf man begagnar sig, såsom fanerogamernas blomning, trädens löfsprickning och löffällning m. m., att begagna vid iakttagelser af tiden för växtlighetens olika utveckling under årets olika tider.

Likasom blomningstiden kan hos somliga löfmossor variera inom vidare gränser, så kan detta äfven stundom inträffa med tiden för fruktmognaden. Isynnerhet utmärka sig vintermossorna för den långa tid, hvarunder deras frukter mogna. Så synes lockfällningen hos Dicranellae och Pylaisia ofta på samma ställe kunna fortgå ända till $4-5$ månader, eller från December till April, och $\mathrm{i}$ de ofvannämnda flororna står ofta fruktmognadstiden för vintermossor rigtigt angifven att inträffa från hösten till våren. En lockfällning, som varar ända till 4 eller 5 månader, är visserligen lång. Om lockfällningen hos de ofvannämnda mossorna kan fortgå under hela 4 till 5 månader, så beror dock detta på den tröghet, hvarmed växtlifvet under denna årstid fortgår, och lifsyttringarne hos alla andra mossor fortgå samtidigt lika trögt. De samtidigt lockfällande mossorna hafva lika långsamt fullgjort sitt arbete. Om deremot t. ex. Meesia uligiginosa håller på omkring en månad under högsommaren med lockfällningen, så hafva under samma tid flera andra mossor med kortare lockfällningstid kunnat efter hvarandra hinna fälla sina lock. Frånse vi vintermossorna, hvilkas lockfällningstid blir utdragen genom trögheten af lifsfunktionerna under den för lifvet 
fiendtliga köldens inverkan, och vända oss till de under lifligare växtlighetsperioder fruktsättande mossorna, så finnes det äfven bland dem några, hvars fruktmognad varierar inom vidare gränser, fast ej på långt när så vida, som vintermossornas. De sommarmossor, hvilkas tid för fruktmognaden visat sig mest varierande, äro följande, som fälla locken:

Amblystegium serpens i Ångml. från midten af Juni till omkring den 1 Sept., eller under $2 \frac{1}{2}$ månader; dock fruktsätter denna art normalt omkring den 1 Juli;

Plagiothecium piliferum i Ångml. stundom från början af Juli till in $\mathrm{i}$ September, eller under mera än 2 månader. Normala lockfällningstiden infaller dock i Ångml. omkring den 1 Sept.;

Hypnum uncinatum i Nordlanden och Ångml. från midsommar till slutet af Augusti, eller under 2 månader;

Bryum lacustre från slutet af Juni till slutet af Augusti, eller under 2 månader. Exemplaren af denna art voro dock från temligen vidt skilda trakter, så att variationen på ett och samma ställe torde blifva mindre;

Cynodontia gracilescens och polycarpum från midsommar till midten af Augusti, eller under nära 2 månader i Ångermanland;

Orthotrichum affine från midten af Juni till slutet af Juli, eller under $1 \frac{1}{2}$ månad i södra Sverige;

Meesia uliginosa enligt exemplar från Nordlanden från början af Juli till början af Augusti, eller under en månad;

Orthotrichum fastigiatum från slutet af Maj till slutet af Juni, eller under en månad i södra Sverige.

Största variationen visar sålunda Amblystegium serpens af sommarmossorna eller $2 \frac{1}{2}$ månader, då deremot vintermossornas fruktmognad ibland kan varierande infalla under $4-5$ månader. Dessutom finnes det äfven en del andra mossor, hvilkas fruktmognadstid kan vara mer än vanligt lång, men dock varierar inom trängre gränser, än de ofvannämndas.

Ibland dessa senare hafva vi äfven en del löfmossor, hos hvilka ofta i samma tufva frukterna äro mycket olikgamla, och hvilka man derutaf ser äfven måste hafva en något mera obestämd och längre lockfällningstid, än de mossor, hvilka alltid, såsom fallet är med det öfvervägande flertalet, på samma lokal hafva alla frukterna i samma utvecklingsstadium. Vanliga med olikgamla frukter i samma tufva äro Meesia uliginosa, Amblystegium serpens, Physcomitrium, Bryum intermedium enligt Bryol. Eur., 
Bryum lacustre, Tayloria serrata, Didymodon rubellus, Tortula aloides enligt Bryol. Eur., m. fl.

Äfven mossor med kortare och mera bestämd fruktmognadstid kunna stundom utom den normala lockfällningstiden fälla sina lock, men då vanligen i så enstaka fall, att de ändå måste anses enligt regeln tillhöra en viss tidpunkt. Likaså har nog äfven bland fanerogamerna t. ex. Prunus Cerasus en bestämd blomningstid, vid Hernösand omkring och straxt efter midten af Juni; men blommor kunna dock hos densamma ganska ofta utvecklas äfven senare på sommaren, stundom till och med i slutet af Augusti, så att mogna frukter och blommor finnas samtidigt. Exempel på lockfällning på andra tider, än de vanliga, lemna följande mossor, som voro i lockfällning före den vanliga tiden, nemligen Bartramiae crispa och ityphylla vid Hernösand de första dagarne af Juni 1870, Dicranum spurium i Östergötland $\frac{3}{6} 73$ och Dicranum Schraderi vid Hernösand $3 \frac{30}{7} 73$ m. fl. Exempel på ovanligt långt efter den vanliga tiden lockfällande löfmossor lemna deremot Hypna cordifolium och stellatum, hvilka ännu de första dagarne af Augusti år 1874 vid Hernösand kunde finnas med lock, Fissidens adianthoides, som vid Hernösand ännu den $2 \frac{3}{6} 74$, och Pogonatum alpinum, som sammastädes ännu den $1 \frac{9}{8} 74$ stundom hade locken qvar m. fl. Efter den vanliga lockfällningstiden finna vi dock oftast hos Grimmiae och Racomitria friska, unga frukter med lock, emedan de troligen likt Orthotricha ofta blomma utom den normala blomningstiden. Hos Orthotricha hafva vi redan sett, att en del arter härigenom till och med normalt få en temligen långt utsträckt tid för fruktmognaden. Hos Grimmiae och Racomitria uppträda dessa efterliggare dock så enstaka, att derför ej den egentliga fruktmognadstiden behöfver utsträckas längre, utan dessa senare utvecklade frukter få hos dem anses såsom abnormiteter. Såsom exempel på sådana sena frukter må anföras Grimmia pulvinata med lock från ÖG. $\frac{1}{768}$, Racomitrium patens från Romsdalen $2 \frac{9}{6} 72$ med unga frukter och R. protensum från Nerike $3 \frac{1}{7} 69$ med lock. I naturen äro dessa enstaka, försenade frukter ej vilseledande, emedan der den stora massan af frukter är på normalt sätt utvecklad, men i herbarier kunna de vara dess mera vilseledande, emedan der i vanliga fall ej några massor af frukter förefinnas, och isynnerhet lockbärande frukter väl helst uppsökas för insamling. 
I det föregående hafva vi sett, att mossor på olika breddgrader kunna fruktsätta på olika årstider, och att då under en nordligare breddgrad fruktmognaden vanligen framflyttas till en senare årstid. Inom Skandinavien eger troligen äfven samma förhållande rum med vårmossorna, fastän till en mindre grad och mindre regelbundet. Under de i sydliga Sverige ofta förekommande barvintrarne kunna troligen de $\mathrm{i}$ det öfriga Skandinavien till Såningstiden hörande mossorna ibland fälla sina lock, om man får döma från t. ex. Anomodon viticulosus, som i December 1852 i Danmark hade börjat fälla locken, och af Thujidium tamariscinum, som uti Danmark i Januari 1853 redan fält sina lock. Dessa exempel äro visserligen tagna från Danmark, dock från trakter af detta land, som ligga $i$ jemnhöjd med vårt sydligaste landskap. Tyvärr har förf. ej haft tillgång till tillräckligt material från de sydligaste landskaperna af vårt land, för att kunna komma till några säkrare slutsatser angående denna intressanta fråga.

Förutom denna öfvergång af fruktmognaden till en senare årstid, som troligen hos några mossor eger rum på en nordligare breddgrad äfven inom Skandinavien, finnes det äfven några löfmossor, som på olika ställen inom Skandinavien fruktsätta på olika årstider, utan att förf. lyckats spåra någon mera allmängiltig lag för detta förhållande. Sålunda fruktsätta följande mossor under en tidigare period af året $\mathrm{i}$ sydliga, än i nordliga Skandinavien:

Pterigynandrum i slutet af Juli i Upsala-trakten och i södra Sverige, i Nordlanden deremot i slutet af Augusti;

Hypnum fastigiatum liktidigt med $\mathrm{H}$. cupressiforme omkring den 1 Maj i Nerike, i Nordlanden och Österbotten omkring den 1 Augusti;

Seligeria Donnii i södra Sverige omkring den 1 Augusti och omkring den 1 September i Nordlanden;

Seligeria tristicha $\beta$ patula $i$ slutet af Juni på Gotland, och hufvudformen omkring den 1 Augusti i Nordlanden.

Följande fruktsätta åter långt tidigare $\mathrm{i}$ nordliga trakter, än i sydliga:

Plagiothecium Mühlenbeckii i förra hälften af Juli i Nordlanden och Romsdalen, i Ångml. i slutet af September;

Plagiothecium nitidulum i Juli i Nordlanden och i Augusti och September i Ångml.;

Plagiothecium piliferum vanligen i Juli i Nordlanden; sällan i Juli, utan normalt i slutet af Augusti och i September uti Angml.; 
Encalypta brevicolla under den tidiga våren, eller under Såningstiden, i Norrland, såsom i Jemtland, Medelpad och Helsingland, men deremot vid midsommaren och tiden straxt derefter enligt exemplar från Upsala och äfven från Laxfjället i Um. Lpm; i »Skandinaviens flora» står den af Lektor Hartman angifven för Maj och Juni.

Det är högst sällsynt, att en löfmossa sätter frukt 2 gånger på samma år. I »Bryologia Sileciaca» säges det om Bryum Warneum: "Diese seltene Art fruktificirt nach E. Ruthe zweimal im Jahre: Mitte Juni und September bis October.» De uppgifter och exemplar af arten, som förf. sett, synas bestyrka detta påstående. Äfven Bryum calophyllum sätter troligen mogna frukter två gånger om året och liktidigt med Bryum Warneum. Denna art fruktsätter nemligen: »Majo» enligt Bryol. Eur., ' »ad aestatis finem» enligt Syn. musc., $\gg 6-9 »$ enligt Skandinaviens Flora och i Juni och September enligt Milde. Exemplar från Southport i England, hvilka äro de enda fruktbärande exemplar med angifven insamlingstid, som förf. sett, hade knappt börjat fälla locken i September 1865. Dessa äro de enda mossor, som förf. känner sätta frukt två gånger på ett år. Om detta inträffar på en och samma lokal, eller om de på hvarje lokal hafva blott en bestämd lockfällningstid på året, kan dock förf. ej på grund af brist på talrika exemplar och naturstudier ej afgöra. Dock synes det åtminstone vid Bryum Warneum vara meningen, att denna mossa på ett och samma ställe fruktsätter 2 gånger årligen.

Omkring 60 af Skandinaviska halföns löfmossor hafva aldrig inom detta område blifvit tunna med frukt. Frukterna äro helt och hållet okända hos 21 af dessa, hvilka derför ej hafva kunnat komma i fråga i det följande kalendariet för fruktmognaden. De öfriga hafva utom Skandinavien blifvit funna med frukter. I fråga om dessa har förf. inordnat de flesta i det efterföljande fruktsättningskalendariet, om han genom fruktexemplar från andra länder eller genom att sluta från närslägtade arter kommit till en bestämd åsigt om den tid, på hvilken de böra fruktsätta, om de $\mathrm{i}$ en framtid skulle komma att finnas fruktbärande äfven i vårt land.

Vid sina bestämningar af blomnings- och fruktsättningstiderna har förf. slutligen till en stor del varit hänvisad till herbariestudier, isynnerhet uteslutande vid de arter, som han ej haft tillfälle att studera i naturen. Några af olägenheterna vid be- 
gagnandet af herbarier hafva redan omnämnts. Äfven många andra finnas, hvaribland den, att man vid begagnandet af andras samlingar nästan alltid lemnas i okunnighet om de yttre påskyndande eller försenande förhållanden, såsom t. ex. höjd öfver hafvet, lokalens läge mot solen eller i skuggan m. m., hvari mossorna ute i naturen kunna vid insamlingen hafva befunnit sig. De förhållanden, hvarunder mossorna i naturen lefvat, är det dock nödvändigt att känna, för att kunna återföra till medelförhållandet de abnormiteter i fråga om tiden för blommornas och frukternas utveckling, som lokala förhållanden ofta kunna förorsaka. Derför har förf. alltid försökt låta de egna samlingarne utgöra grundvalen för undersökningarne. Till fruktmognadstidens bestämmande lemna dock herbarierna $\mathrm{i}$ allmänhet rikligt material, emedan i första rummet fruktbärande exemplar till dem insamlas. Härigenom blifva samlingarne deremot ofta otjenliga till undersökningar af blomningstiden, åtminstone hos det stora antal mossor, som ej blomma liktidigt med fruktmognaden. Af många mossor torde derför i herbarier friska blommor aldrig finnas, t. ex. af de under blomningen ytterst små jordmossorna. Helt och hållet odugliga för dessa kalendarii-undersökningar hafva dessutom en mängd herbarie-exemplar blifvit derigenom, att insamlingstiden ej blifvit på dem antecknad.

Den i det följande kalendariet begagnade tidräkningen är öfverensstämmande med den redan af Linné i »Calendarium Florae» framstälda indelningen af året i 12 vegetativa utvecklingsperioder (Menses), för hvilka indelningsgrunden är tagen från de mest $\mathrm{i}$ ögonen fallande utvecklingsstadierna under året hos fanerogamvegetationen. Prof. Fries har äfven i sin afhandling om Svamparnes kalendarium begagnat samma indelning af året. För vinnande af enhet i tidräkningen, hvarigenom en jemförelse mellan de olika växtklassernas utveckling efter årstiderna underlättas, hafva äfven löfmossorua blifvit inordnade i samma perioder. Ett annat skäl och det väsendtligaste, hvarföre förf. begagnat de redan uppstälda perioderna, är det dessutom, att denna indelning af året från växtlifvets synpunkt väl är den naturligaste, som kan uppställas.

Indelningen af ₹rret i 12 perioder på grund af växtlighetens olika utvecklingsstadier passar dock ej lika bra för alla delar af Skandinavien. Vid indelningen har afseende närmast fästats på 
förhållandena vid Upsala, och blir den derföre äfven för detta ställe naturligast och mest symmetrisk. Perioderna blifva med afseende på längden här temligen likstora; dock blir äfven här Vinterperioden (Mensis glacialis) 2 till 3 månader lång, under det några perioder under de tider på året, då växtlighetens utveckling går raskare, endast blifva 3 veckor långa. I sydligare delar af Skandinavien blifva vinterns 3 perioder kortare, hvaremot vårens och höstens perioder blifva längre. Ju längre mot norr vi komma, desto längre blifva deremot vinterns perioder och desto kortare derföre de öfriga. Redan i mellersta Skandinavien omkring den 63:dje breddgraden, d. v. s. litet norr om Hernösand i Sverige och ungefär vid Trondhjem i Norge, upptaga de 3 vinterperioderna, eller den tid, under hvilken snön der täcker marken, ofta halfva året eller 6 månader. De öfriga 9 perioderna måste derför blifva ganska korta, och en af dem upptager här äfven blott omkring 2 veckor. Derigenom att utvecklingen under den egentliga regetationstiden här går fortare, medhinnes dock på en kortare tid samma utveckling, som i sydligare trakter kräfver en längre tid, och perioderua visa sig sålunda ännu i mellersta Skandinavien, oaktadt sin korta varaktighet, lika skarpt begränsade, som i sydligare trakter. Undantag härifrån visa dock 8:de och 9:de perioderna, Skördetiden och Eftersommaren, hvilka i mellersta Skandinavien sammanflyta, så att de, åtminstone efter den vid Upsala för dessa perioder begagnade begränsningen, ej kunna från hvarandra skiljas. Möjligen kunde, om skiljegränsen för dessa perioder toges från något annat, än från den artificiella skördetiden, en naturlig gräns mellan 2 perioder under denna tid af året finnas äfven för mellersta Skandinavien. För detta kalendarium har det dock ej ansetts nödigt att skilja dessa 2 perioder, utan hafva de blifvit skildrade i ett sammanhang, emedan inga större förändringar i löfmossvegetationens utseende äro att se under den tid, som de upptaga. Ju längre vi komma mot norden, och ju högre vi komma öfver hafvet, desto längre blifva, såsom vi redan sagdt, vinterns perioder och desto kortare den egentliga vegetationstiden och dess 9 perioder. Det blir derför allt svårare att der kunna sönderdela vegetationstiden i de många perioder, som tydligt finnas $\mathrm{i}$ sydligare eller lägre trakter. Uppe på fjällen i lafbältet, der vegetationstiden äfven i de lägsta delarne uppgår till föga öfver 2 månader, från midsommartiden till omkring den 1 Sept., âr derför den Linnéanska indelningen af året fullkomligt omöjlig att tillämpa. ¿ den 
andra sidan vill dock förf. ej heller biträda den af Prof. Fries uttalade åsigten ${ }^{1}$ ), att det ofvan videregionen skulle finnas blott 2 årstider, vinter och vår, hvilka omedelbart aflösa hvarandra. I de nedre delarne af lafbältet hinna flera blommande generationer efterträda hvarandra under en vegetationstid, och man kan der ännu ganska tydligt urskilja 4 årstider. En vår, som i dessa trakter, der utvecklingen går så fort, skulle fortvara öfver 2 månāder, är väl äfven allt för lång. Först längre upp, närmare den eviga snöns gräns, der endast vårens representanter bland fjällväxterna hinna slå ut sina blommor, under det de andra mera senblommande fjällväxterna aldrig hinna till blomning, kan man säga, att endast 2 årstider, en lång vinter och en kort vår, finnas. Gå vi änuu längre upp på fjällen, komma vi slutligen, på en för olika ställen inom Skandinavien vexlande höjd öfver hafvet, till den eviga snöns eller den eviga vinterns område.

I det följande kalendariet hafva först gränserna för de olika perioderna blifvit angifna för olika delar af Skandinavien. I främsta rummet hafva gränserna blifvit angifna för mellersta Skandinavien eller Hernösands-trakten vid omkring 63:dje breddgraden, emedan genom dessa gränser medeltiden i det närmaste utvisas för perioderna $\mathrm{i}$ hela det Skandinaviska låglandet. Sedan hafva gränserna för perioderna vid Upsala, hvars nordliga bredd är $59 \frac{3}{4}$ grader, angifvits, samt äfven de ungefärliga gränserna för desamma under Skandinaviska halföns sydligaste breddgrad, eller den 56:te. Slutligen hafva, så vidt det varit möjligt, de tider blifvit angifna, under hvilka de serskilda perioderna infalla i Nordlanden under polcirkeln, vid $66 \frac{3}{4}$ grader nordlig bredd; samt äfven för en perịod den sannolika gränsen vid Skandinaviens nordligaste punkt på 71:sta breddgraden.

Genom dessa begränsningar blifva gränserna för perioderna äfven i mellanliggande delar af Skandinavien antydda. I fråga om vinterperiodernas begränsning torde den anmärkningen kunna göras, att snön blifvit allt för mycket tagen i betraktande och isarne deremot allt för mycket lemnade utan afseende. Orsaken härtill ligger deruti, att löfmossvegetationens utveckling ganska mycket är beroende af snöförhållandena. Är marken snöklädd, så är löfmossvegetationen naturligtvis stillastående i sin utveckling; blir marken åter bar, och temperaturen höjer sig det minsta

') Jfr $>$ Botaniska Utflygter», 1.sta delen, sid. 311 . 
öfver nollgraden, så fällas locken af ganska många mossor, såsom vi skola se $i$ det följande. I fråga om trakterna kring polcirkeln har förf. åter endast för de till den lifligaste vegetationstiden hörande perioderna kunnat komma till några åsigter om gränserna. Dessa perioder äro väl äfven de, hvilkas gränser det $\mathrm{i}$ detta kalendarium är vigtigast att känna.

För de gjorda begränsningarne af perioderna har förf., utom sin egen erfarenhet och de talrika häntydningar, som han vid sina studier af löfmossornas kalendarium fått om de tider, då växtligheten på olika ställen inom Skandinavien är lika långt kommen i utveckling, äfven begagnat andra källor. I främsta rummet hafva begagnats de $i$ inledningen till denna afhandling omtalade arbetena, som redan förut behandlat till vårt Skandinaviska vegetationskalendarium hörande frågor. Isynnerhet hafva bland dessa afhandlingarme af Prof. Fries, »Om våren» och om »Svamparnes kalendarium», varit af stort gagn, mest genom uppgifterna om utvecklingsperiodernas gränser vid Upsala. Utom dessa arbeten har förf. äfven haft tillfälle att på härvarande Observatorium få genomgå de observationslistor, som redan inkommit för åren 1873-75, hvarigenom isynnerhet begränsningen af perioderua för Skandinaviska halföns sydligaste breddgrad blifvit möjlig.

Slutligen må det angående uppställningen omnämnas, innan vi öfvergå till det egentliga kalendariet, att $\mathrm{i}$ detta vid hvarje serskild period, sedan den blifvit på ofvannämnda sätt begränsad, en skildring blifvit lemnad först af de för densamma utmärkande, blommande löfmossorna och sedan af de under densamma fruktsättande, hvarvid isynnerhet framhållits, att oftast närslägtado arter eller ock likartade lokaler tillhörande arter blomma eller få mogna frukter samtidigt. De löfmossor, som ej på Skandinaviska halfön blifvit funna med frukter, men likväl införts i fruktmognadskalendariet under de perioder, under hvilka de troligen skulle fruktsätta i Skandinavien, om de en gång skulle finnas derstädes med frukter, hafva omslutits med ett klammer. I några fall, då förf. ej kunnat komma till en fullt säker åsigt, har han angifvit, att han slutit sig till blomnings- eller fruktsättningstiderna, dels ex analogia från närslägtade arter, dels äfven i fråga om fruktmognaden från andra författares uppgifter, genom de inom klammer stående uttrycken sex analogia» och senligt författarne». 
I. Vintern eller Isperioden (Mensis glacialis L.) varar i mellersta Skandinavien, eller vid Hernösand, från vintersolståndet till omkring den 1 April, eller 3 kalendermånader. Snön täcker här, utom i ovanliga undantagsfall, hela denna tid marken, och först omkring och efter vårdagjemningen börjar solens värme blifva densamma öfvermägtig. Snöns öfversta lager börja då att smälta om dagen, men om nätterna fryser åter dess yta till en fast skorpa eller till §skare», hvilkens börjande bildning utgör en skarp och tydlig gräns mellan snöns herravälde och det börjande snösmältnings-arbetet. Vid Upsala varar perioden enligt Linné från vintersolståndet till vårdagjemningen och innefattar, enligt Professor E. Fries, Januari och i vanliga år hela eller större delen af Februari. Såsom vi af ofvanstående gränser se, hafva Linné och Fries något skiljaktigt angifvit tiden för slutet. Orsaken härtill| ligger deruti, att i södra Sverige ingen skarp gräns finnes mellan denna period och den nästa. Ofta kan nemligen der under denna blidväder inträffa, så att snön försvinner, trädens knoppar börja svälla, och hängena slå ut. I Skåne kunna t. o. m. blommor stundom finna spå fältet under hela denna tid. Ofta kan äfven vintern i hela sin stränghet återkomma under den nästa. Deremot ju längre vi komma mot norden, desto skarpare utpräglad genom snöns envälde framträder perioden, och desto fullkomligare och mera oafbruten blir under densamma växtverldens hvila, åtminstone i Sverige. På Norges kust, der vintertemperaturen är mildare, torde förhållandet vara något olika mot $\mathrm{j}$ Sverige; dock kan förf. ej härom yttra något bestämdt. Likaså kan ej slutgränsen för denna period angifvas för något nordligare ställe, än för det i mellersta Skandinavien belägna Hernösand. Den framflyttas dock naturligtvis allt mera, ju längre mot norden vi komma, så att härigenom perioden mot norden blir allt längre. Åfven ökas vinterns längd, ju högre öfver hafvet vi komma, tills den slutligen vid en för olika ställen olika höjd öfver hafvet herrskar hela året om, hvilket inträffar vid polcirkeln på gränsen mellan Sverige och Norge redan vid 4000 fot öfver hafvet.

Blomning. Under denna tid blommar ingen löfmossa, men hos de under den 3:dje perioden blommande arterna kunna vi nu finna redan på hösten anlagda hanblommor med fullt tydliga, unga antheridier.

Fruktmognad. I största delen af Skandinavien, eller alltid $\mathrm{i}$ de nordliga och mellersta delarne och stundom äfven i de 
sydliga, är marken hela denna tid höljd med snö. Då detta är fallet, är växtligheten stillastående $\mathrm{i}$ sin utveckling, och bland mossorna hafva vi således inga, som då under denna tid utveckla mogna frukter. Emellertid hafva ganska många löfmossor före vinterns inträdande så långt utvecklade frukter, att dessa vid första blidväder fullt mogna och fälla sina lock eller affalla. Dessa utmärka genom sin fulla mognad denna period, då under densamma blidväder inträffar och snön försvinner, hvilket, såsom vi ofvan sagt, ofta kan inträffa i södra Skandinavien. Ibland de pleurokarpisku mossorna kunna endast Hypna Crista castrensis och purum normalt fälla locken under denna tid. Dessutom börjar nu Pylaisia fälla locken och $\mathrm{i}$ de sydligaste delarne af Skandinavien stundom en och annan (t. ex. Thujidium tamariscinum), som enligt regeln tillhör Såningstiden. Ganska många akrokarpiska mossor tillhöra deremot perioden, och äro dessa uteslutande jordmossor, af hvilka de flesta redan under de 2 sista perioderua af det föregående året, åtminstone vid pressning, kunde fälla locken. Sådana jordmossor äro: Pogonata urnigerum och eapillare, Catharineae, Brya uliginosum, pallens, purpurascens, arcticum (och Brownii?), Tortulae fallax, recurvifolia, unguiculata, aloides, ambigua, stellata och brevirostris, Trichostoma tophaceum och rigidulum, Leptotrichum tortile $\beta$ pusillum, Pottiae Starkei och truncata, Dicranellae, Dichodontium samt Gymnostomum squarrosum. Nästan alla dessa jordmossor bibehålla dock ofta locken äfven in $\mathrm{i}$ nästa period.

II. Sidvintern eller Tövädersperioden (Mensis regelationis L.) börjar vid Hernösand omkring den 1 April med skarbildningen, hvilken utvisar, att snöns herravälde börjar brytas, oeh varar till den 1 Maj eller första veckan af Maj, då vanligen blott enstaka snödrifvor finnas qvar, och de första blommorna, alens hängen och blåsipporna, slå ut. I senår, t. ex. 1867, kan slutet framskjutas ända till den 1 Juni, och således periodens slutgräns variera en hel månad. För Upsala angifvas periodens gränser: »från snösmältningens början till flodernas isgång» af Linné; »börjar i slutet af Februari och fortfar med mer och mindre häftiga recidiv af vinter till den 15-21 April», enligt Prof. E. Fries. I sydligare delar af Skaudinavien slutar perioden tidigare. Om man får döma från talrika exemplar af de små Fissidensarterna, hvilkas lockfällning infaller på gränsen mellan denna period och den nästa, så infaller dock slutgränsen liktidigt med Upsala vid 
det omkring $1 \frac{1}{2}$ breddgrad sydligare belägna Grenna, men vid Örebro, som endast ligger $\frac{1}{2}$ grad sydligare, omkring den 1 April eller 2 till 3 veckor tidigare, än vid Upsala. Enligt Prof. E. Fries slutar perioden $i$ Skåne $i$ slutet af Februari. I södra delarne af Skandinavien förekomma under densamma ofta återfall af vinter, och är derför denna period ej skarpt skild från den föregående. Likasom under den förra perioden felas der ofta snö äfven under denna, men om sådan finnes, så smälter den nu. Ej heller slutet är der konstant. Då den största vexlingen vid Hernösand steg till en månad, kan den, enligt Prof. E. Fries, vid Femsjö i Småland uppgå ända till 2 månader, $\mathrm{i}$ det att slutet vexlar mellan den 1 Mars och 1 Maj. Några gränser för perioden kan förf. ej för nordliga Skandinavien uppgifva, utan endast, att derstädes densamma, hvilken der, likasom vid Hernösand, utmärkes genom sitt energiska och nästan oafbrutna snösmältningsarbete, i vanliga år såväl börjar som slutar senare, ju längre mot norden vi komma.

Blomning. Ingen löfmossa blommar ännu normalt. Endast i undantagsfall finnas nu mogna blommor hos några löfmossor, t. ex. hos Isothecium myurum, Orthotrichum obtusifolium och Andraea petrophila. Den tidigaste vårblomman hos löfmossorna har förf. bland dessa funnit hos Orthotrichum obtusifolium, hvilken vid Upsala visade utvecklade blommor den 9 Mars 1874.

Fruktmognad. Likasom under föregående period, så är det äfven under denna $\mathrm{i}$ dess helhet blott $\mathrm{i}$ de sydligare delarne af Skandinavien, som marken kan vara bar och temperaturen tillräckligt hög, för att fruktmognad skall kunna inträffa. I slutet af perioden, då marken öfver hela Skandinavien börjar blifva bar, fälla äfven $i$ de mellersta och norra delarne de vintermossor sina lock, som ofta redan förut börjat sin lockfällning i sydligare delar af landet. Ibland de pleurokarpiska mossorna fälla Hypna Crista castrensis och purum sina lock äfven under denna period, isynnerhet $\mathrm{i}$ de trakter, som under den föregående varit snöhöljda. En och annan af de normalt till nästa period hörande pleurokarpiska mossorna kunna dessutom börja fälla locken redan i slutet af denna, t. ex. Eurhynchia praelongum, piliferum och striatum, Homalothecium, Leucodon m. fl. Bland de akrokarpiska mossorna höra flera, än bland de pleurokarpiska, till denna tid, men det är bland dem fortfarande endast jordmossor, som fruktsätta. Till de till den förra perioden hörande, hvilka alla äro utmärkande äfven för denna, komma dessutom Bryum argenteum, 
Ångströmia och Sphaerangium, samt i slutet Pogonata aloides och nanum, Pottiae intermedia och cavifolia, Fissidens-arterna samt Microbryum. Bland dessa kunna väl Fissidens-arterna vid pressning fälla locken $i$ herbarier äfven under den föregående perioden, men ute $\mathrm{i}$ naturen tillhöra de normalt slutet af denna.

III. Saningstiden (Mensis germinationis L.) varar i mellersta Skandinavien, eller vid Hernösand, från slutad snösmältning $\mathrm{i}$ första veckan af Maj till löfsprickningens början omkring den 1 Juni. Vid Upsaliı börjar perioden vid islossningen omkring den 15-21 April och slutar vid löfsprickningens början omkring den 15 Maj. Sålunda slutar perioden vid Upsala ungefär 2 veckor förr, än i mellersta Sverige. I de sydligare delarne af Skandinavien både börjar och slutar perioden tidigare. I Skåne kan den till och med börja i slutet af Februari, enligt Prof. Fries, och den slutar der, så vidt det kan dömas af det knapphändiga material, som förefinnes, vanligen efter midten af April, troligen omkring den 20. I de nordligare delarne af Skandinavien både börjar och slutar i vanliga fall perioden senare, äı $\mathrm{i}$ den mellersta delen, dock felas material för att kunna bestämdt angifva gränserna för något nordligare ställe, än Hernösand. Denna periods gränser kunna vara ganska vexlande och äro, isynnerhet utefter Skandinaviens ostkust, beroende på de olika isförhållandena $\mathrm{i}$ de skilda, större vattensamlingar, som stöta till dess kuster. Vid Gefle börjar sålunda denna period, relativt till sitt ringa afstånd från Upsala, vanligen temligen mycket senare, än på sistuämda ställe, hvilket har sin orsak deruti, att Gefle ligger vid Bottniska viken, hvars vanlige ı längre qvarliggande is försenar våren $\mathrm{i}$ dess framtågande mot norden. Vid de serskilda hafven kan dessutom, genom drifisens af vindarne beroende längre qvardröjande under olika år vid olika delar af kusterna, vårens framtågande under olika år visa ganska stora olikheter. Hopas mycken drifis vid någon del af kusten, så afkyles naturligtvis derigenom luften, och våren försenas der i sitt framtågande. På detta sätt kan genom hafsisens hopande vid de sydliga hafskusterna våren der så försenas, att på långt nordligare ställen växtligheten liktidigt hinner till större utveckling, än på de sydligare, som omgifvas af hafsisen.

Blomning. Ännu är det för kallt för mossorna att mera allmänt börja blomma, hvarföre äfven endast få under denna tid blommande arter finnas, ännu färre, än fanerogamfloran har att 
uppvisa. Några pleurokarpiska mossor blomma dock nu samtidigt med lockfällningen, nemligen Isothecia, Homalia samt mot slutet Eurhynchia strigosum och diversifolium. Pylaisia och Leskea nervosa börja äfven att blomma i slutet. Bland de akrokarpiska mossorna blomma 2 jordmossor, Pogonata urnigerum och capillare. Ibland sten- och klippmossorna blomma Leptotrichum flexicaule, Grimmia Mühlenbeckii och stundom Grimmia ovata, då den ej, likt Gr. Donnii, blommar straxt efter midsommar och använder 22-23 månader på fruktutvecklingen. Grimmiae pulviuata och unicolor, Racomitrium canescens samt Andraeae börja nu äfven normalt att blomma och fortsätta dermed till in $i$ nästa period. Talrikast representerade äro dock nu Orthotricha, af hvilka likväl blott 2 uteslutande eller mera normalt tillhöra denna tid, nemligen 0 . urnigerum och diaphanum; andra Orthotricha börja nu att blomma, men fortsätta dermed en eller flera perioder framåt, såsom 0 . rupestre, fastigiatum, obtusifolium, cupulatum, gymnostomum, macroblephare (ex analogia), Killiasii, Sommerfeltii, arcticum, Blyttii, laevigatum (ex analogia) och anomalum. I Nordlanden synas dessutom de stora Dicrana (t. ex. D. fuscescens och elongatum), som i Sverige blomma på gränsen mellan 6:te och 7:de perioderna, blomma under denua tid. Likaså blomma nu i Nordlanden Cynodontia virens och Wahlenbergii, hvilka i Sverige tillhöra första början af 5 :te perioden.

Fruktmognad. Under denna period fruktsätta omkring $\frac{1}{4}$ af våra Skandinaviska löfmossor, så att de fruktsättande arternas antal nu uppnår sitt maximum. Detta är väl äfven den naturligaste tidpunkten för sporsådden, samtidigt med det att öfriga växters frön gro och landtmannen sår sin säd. Isynnerhet äro många pleurokarpiska mossor utmärkande för denna tid genom sina nu lockfällande frukter. Ibland dem tillhöra nemligen denna tid en stor del af de i skogar, på träd, stenar eller jord växande arterna, såsom Hylocomia (utom H. splendens), Hypna Schreberi, molluscum, imponens, cupressiforme och fastigiatum, af hvilka den sista blott i Nerike, ej i Nordlanden, tillhör denna tid, Brachythecia, af hvilka $\mathrm{Br}$. velutinum är senast och nästan tillhör gränsen till nästa period, Camptothecium lutescens, Rhynchostegium murale, Eurhynchia, af hvilka de flesta kunna börja fälla locken redan $i$ slutet af föregående period och Eurh. strigosum tillhör slutet af denna, (Thamnium), Homalothecium, Isothecia, Pylaisia, som kan börja fälla locken redan under den första perioden, men först nu slutar dermed, Platygyrium, (Cylindrothe- 
cium), Climacium, Lencodon, Lescuraea, Antitrichia, Neckerae, Homalia, (Habrodon), (Pterogonium), Thujidia abietinum och tamariscinum, Heterocladia dimorphum (och heteropterum), Pseudoleskea atrovirens, Anomodon-arterna samt Hookeria. Angående tiden för lockfällningen hos dessa mossor hafva författarne ganska stridiga nppgifter; att döma af dessa synas dock de flesta i södra och mellersta Europa fälla locken redan på hösten, och fortgår då derstädes lockfällningen vanligen äfven sedan under vintern. Hypnum rugosum och Rhyncostegium depressum tillhöra troligen äfven denna period, ehuru förf. ej sett tillräcklig mängd exemplar af dessa mossor, för att om dem hysa en bestämd åsigt. Det i strömmar och bäckar växande Rhynchostegium rusciforme tillhör slutligen äfven denna tid.

Äfven många akrokarpiska mossor fruktsätta under perioden, men är det bland dem isynnerhet på stenar och klippor, ej, såsone under de 2 föregående perioderna, på jord växande arter, som för denna tid äro de mest utmärkande. Isynnerhet äro nu Grimmiae och Racomitria i ögonen fallande genom sina vackra frukter, dock mest mot slutet af perioden. Bland Grimmia-arterna tillhöra de flesta slutet af denna period; några tillhöra dock normalt den nästa, och komma dessa att nämnas vid densamma; angående Gr. apiculata, contorta, alpestris och atrata äro visserligen författarnes uppgifter mycket stridiga, men enligt de exemplar, som förf. sett af dessa mossor, torde de dock i Skandinavien fälla locken under denna tid. Bland Racomitria tillhöra R. microcarpum och sudeticum slutet af perioden; R. patens, ellipticum och heterostichum tillhöra gränsen mellan denna period och den nästa. Andra sten- och klippmossor, hvilkas frukter nu mogna, äro Encalypta brevicolla (i Norrland), Ptychomitrium, Hedwigia, Coscinodon, Weissiæ crispula, compacta, cirrhata, Wimmeri, Schisti, denticulata och fugax (de 3 sista först mot slutet), Gymnostomum rupestre samt på gränsen till nästa period Andraeae. Dessutom tillhöra troligen Tetrodontia denna tid. Äfven några utmärkande jordmossor finna vi nu med mogna frukter, nemligen Leptotrichum homomallum, Didymodon luridus, Pottia lanceolata; Leucobryum och Microbryum, samt mot slutet Pyramidula och Discelium. Från föregående period gå stundom in $\mathrm{i}$ dennas början Pogonata nanum och aloides, Tortula brevirostris, Trichostoma tophaceum och rigidulum, Pottia cavifolia, Fissidens adianthoides, Dicranellae rufescens och varia, Ångströmia (till följd af sin höga växtlokal) och Sphaerangium. Af Mnia visa sig nu mot slutet ett par för- 
poster uti Mnia subglobosum och punctatum, och slutligen fälla bland Orthotricha 0 . diaphanum och gymnostomum under denna tid locken.

IV. Löfsprickningen (Mensis frondescentiae L.) börjar vid Hernösand omkring den 1 Juni och slutar strax efter häggens afslutade blomning, eller omkring den 20 Juni. Vid Upsala varar perioden från medlet af Maj till omkring den 8 Juni. Denna period börjar således 2 veckor förr vid Upsala, än i mellersta Sverige, och slutar omkring 12 dagar förr. Schübeler har i »Flora oder Botanische Zeitung» 1830, n:o 23, i en afhandling om våren visat, att hastigheten af vårens framtågande i mellersta Europa är 4 dygn på hvarje breddgrad, och har derpå anfört exempel från körsbärsträdets på olika ställen inträffande olika blomningstid, hvilken infaller nära slutet af denna period. Emot norden skall dock vårens hastighet ökas, så att den ej behöfver 4 dagar för att tillryggalägga en breddgrad. Skilnaden mellan Hernösand och Upsala är i afseende på bredden 3 grader. Således borde skilnaden $\mathrm{i}$ tid mellan slutet af denna period vid dessa 2 ställen vara mindre än 12 dagar. Att den för mellersta Europa funna tågordningen likväl äfven i detta fall synes hafva sin tillämpning, torde hafva sin orsak dels uti Bottenhafvets försenande inverkan på vårens framtågande, dels äfven deruti, att Upsala har ett mera kontinentalt läge, hvarigenom utvecklingen mot sommarens gräns påskyndas. Våren börjar nemligen väl tidigare invid de stora vattensamlingarne, än $\mathrm{i}$ det längre ifrån dem belägna landet; men vid sommarens gräns är den inuti landet längre ${ }^{1}$ ) hunnen, än vid kusten, om höjden öfver hafvet icke är desto betydligare. Beräkna vi efter den af Schübeler framställda tågordningen tiden för periodens slut vid Skandinaviska halföns sydligaste och nordligaste punkter, så skola siffrorna visa för den förra en något för tidig och för den senare en alltför sen tidpunkt. Mellan Hernösand och den sydligaste delen af Sverige är afståndet $7 \frac{1}{2}$ grader, och skulle derför vid Skandina-

1) Prof. Fries säger, att vid gränsen till sommaren växtligheten är lika lingt hunnen $\mathrm{i}$ utveckling inuti landet, som vid kusten. Att den inuti landet då hunnit längre, har förf. flerfaldiga gånger sett under utflygter från Hernösand till längre från kusten belägna delar af Ångermanland. För att anföra ett exempel, vill förf. omnämna, att den 15 Juni 1869 häggarne vid Hernösand knappt börjat blomma, under det att vid det 10 mil uppefter Ångermanelfven belägna Sollefteå de redan voro utblommade, ehuru detta ställe ligger betydligt högre öfver hafvet, än Hernösand. 
viska halföns sydpunkt periodens slut infalla allraförst 30 dagar eller en månad förr, än vid Hernösad, d. v. s. omkring den 20 Maj. Så tidigt synes dock ej löfsprickningen i Skåne vara afslutad, utan först omkring den 25 Maj kan den i allmänhet anses vara slut derstädes. Mellan Hernösand och Nordkap är det en skilnad i bredd af 8 grader, således skulle löfsprickningen vid Nordkap vara afslutad allrasist 32 dagar senare, än vid Hernösand. Uti Nordlanden har dock ute vid hafvet under polcirkeln, som ligger omkring 4 grader nordligare, än Hernösand, våren vid löfsprickningens slut redan hunnit omkring 6 dagar fortare, än den skulle hafva hunnit, om den hade följt tågordningen i mellersta Europa, så att perioden vid polcirkeln är slut redan den 1 Juli ${ }^{1}$ ). Utgå vi från polcirkeln och beräkna, vid hvilken tid löfsprickningen bör vara slut vid det 4 grader nordligare Nordkap, så finna vi, att slutet för perioden der infaller sist den 16 Juli eller, om våren äfven på denna väg vunnit 6 dagar under sitt framtågande, omkring den 10 Juli. En väsendtlig skilnad visar det sig dessutom. finnas i afseende på periodens längd i de sydligare och nordligare delarne af Skandinavien. Ju längre vi komma mot norden, desto kortare blir perioden och desto snabbare måste derför naturens utveckling under densamma blifva; s hrad den nordiska våren förlorat i tid, det vinner han i kraft». Vid Hernösand är sålunda perioden redan omkring två veckor kortare, än under Skandinaviska halföns sydligaste breddgrad.

Blomning. Under denna tid blomma ännu ej många löfmossor; det är först mot slutet af denna period och i den nästa, som de något allmännare börja utveckla sina blommor. Bland de pleurokarpiska mossorna blomma nu Hypna cupressiforme och fastigiatum (den senare i Nerike, ej i nordliga Skandinavien), Pylaisia,

1) Såsom bevis derpå, att den 1 Juli löfsprickningen ute via hafvet under polcirkeln är i Nordlanden afslutad, må anföras några exempel från löfmossorna. Racomitria microcarpum, heterostichum och patens, som blomma under löfsprickningstiden, voro i Ranen i Helgeland öfverblommade i 1:sta veckan af Juli 1870 . Webera albicans, Mnium punctatum samt Cynodontia virens och Wahlenbergii hade likaledes i törsta veckan af Juli allmänt fällt sina lock $\mathrm{i}$ Ranen och vid Bodö. Mnium hornum, som fälier locken på gränsen mellan denna period och den nästa, kan dessutom lemna kunskap om tiden för denna periods slut på olika ställen af Skandinavien. Exemplar af denna art, som förf. sett, visade sig i följande utvecklingsstadier: locken voro qvar eller afföllo vid pressning i Ranen $3 \bar{\gamma} 670$, locken afföllo vid pressning vid Bodö $\frac{5}{7} 69$, frukterna voro nästan mogna vid Örebro ${ }_{5}^{7} 73$, och locken afföllo vid pressning på Kinnekulle $\frac{5}{6} 73$. 
Platygyrium, Isothecium myosuroides, Neckera pumila och Leskea nervosa. Några egentligen till förra perioden hörande arter blomma stundom ännu i början af denna, såsom Eurhynchia strigosum och diversifolium, Homalia samt Isothecium myurum. $\mathrm{Nu}$ börja äfven en del blomma, hvilka fortsätta att utveckla mogna blommor äfven under nästa period eller stundom äfven under flera följande perioder, såsom Amblystegia serpens, Juratzkae och troligen radicale, Eurhynchium striatulum, Neckera oligocarpa, Pseudoleskea catenulata och Homalothecium.

Bland de akrokarpiska mossorna äro isynnerhet slägtena Grimmia, Racomitrium, Orthotrichum och Encalypta utmärkta genom sina under denna tid vackra, utvecklade blommor. De flesta Grimmiae tillhöra denna period med afseende på blomningen; de arter, som blomma under den föregående perioden eller under de 2 nästa, äro vid dessa anförda. De Racomitria, som tälla locken på gränsen till denna period eller under densamma, blomma äfven nu, således nästan samtidigt med lockfällningen. Hos de flesta Orthotricha finnas vanligen normalt utvecklade blommor under denna tid; endast hos 0 . Lyellii, lejocarpum, alpestre och puchellum har förf. ej under Löfsprickningstiden funnit mogna blommor. Ibland de öfriga hafva en del redan under den föregående perioden, såsom ock här ofvan blifvit omnämndt, börjat blomma, och afsluta oftast dessa nu sin blomning; 0. rupestre, fastigiatum, obtusifolium och anomalum blomma dock allt framgent under en eller flera perioder. Under denna tid börja dessutom 0 . speciosum och Sturmii samt mot slutet O. Schimperi och pumilum sin blomning. Encalypta-arterna tillhöra normalt denna period och första början af den nästa. Öfriga nu blommande akrokarpiska mossor äro Tetraphis (mest mot slutet), Pogonata aloides och nanum samt Bryum roseum. Leptotrichum flexicaule och Andraeae gå äfven ofta in $i$ denna period. Slutligen hafva vi några, isynnerhet jordmossor, hvilka tillhöra gränsen till nästa period, nemligen Timmiae, Gymnocybe-arterna, Aulacomnium, Tortulae aloides, stellata, ambigua och brevirostris, Dicranellae, (utom D. heteromolla, subulata, curvata, cerviculata och squarrosa), Ångströmia, Cynodontia virens och Wahlenbergii (de 2 sista i Sverige, ej i Nordlanden), Weissia viridula, Gymnostomum microstomum, Systegium (ex analogia), samt Bryum Funckii och troligen äfven Bryum argenteum.

Fruktmognad. Under denna tid fruktsätter normalt blott en pleurokarpisk mossa, nemligen Hylocomium splendens. Nagra 
af de många under den föregående perioden lockfällande pleurokarpiska mossorna kunna dock stundom försenas, så att de äfven nu träffas med lock, t. ex. Hypnum Schreberi, Brachythecium velutinum, Antitrichia och Neckera crispa. Amblystegia Juratzkae och serpens samt Fontinales antipyretica och gracilis börja dessutom stundom redan nu att fälla locken.

Ibland de akrokarpiska mossorna äro isynnerhet jordmossorna karakteristiska för denna tid. Hithörande jordmossor äro nemligen Oligotricha, Weberae albicans, carnea, pulchella, Ludwigii och annotina (den sista enligt författarne, ej enligt exemplar), Schistostega, Encalypta vulgaris, Leptotrichum pallidum (enligt förff.); Weissiae viridula och rostellata, Syștegium, Pleuridia alternifolium och subulatum, Phasca bryoides och euspidatum samt Buxbaumia aphylla och Tetraplodon angustatus, hvilka 2 sista väl äfven helst få anses såsom jordmossor. Pottia lanceolata finnes dessutom ofta med lock ännu i början af denna period, och i slutet börja Funariae fascicularis och Ahnfeltii, Archidium samt Sporledera att visa mogna frukter. Dessutom försköna Mnia denna tid. Mn. subglobosum och punctatum hafva dock nästan slutat fälla locken i början; Mnia medium, affine, undulatum, cuspidatum, rostratum och cinclidioides äro åter vackrast vid slutet. Äfven många sten- och klippmossor fruktsätta nu. Bland Grimmiae tillhöra sålunda Gr. anodon, pulvinata, commutata, montana, unicolor och mollis normalt denna tid, och äfven de öfriga arterna hafva sällan slutat fälla locken vid periodens början. Racomitria aciculare, protensum och canescens höra likaledes till perioden; $R$. lanuginosum och fascisculare börja i dess slut få mogna frukter, och de öfriga Racomitria fälla ännu i början af denna tid locken, utom R. microcarpum och sudeticum, hvilka 2 sistnämnda då redan hafva slutat sin lockfällning. Bland öfriga på likartad lokal växande akrokarpiska mossor eger nu fruktmognaden rum hos Amphoridium lapponicum, Zygodon viridissimus och Seligeria crassinervis (hos de två sista enligt förff.). Andraea-arternas frukter hafva dessutom ej slutat uppspringa vid periodens början, och Bartramiae (t. ex. crispa och ityphylla) börja stundom redan nu att fälla locken. Nu fruktsätta äfven de i kärr växande Cynodontia virens och Wahlenbergii. Slutligen visa Orthotricha nu betydligt flera arter med mogna frukter, än under förra perioden, nemligen 0 . lejocarpum, urnigerum, obtusifolium, pulchellum, macroblephare, Killiasii, Sommerfeltii, arcticum, Blyttii, och dessutom börja bland dem vid slutet af perioden $O$. fastigiatum, tenellum, laevigatum och anomalum att afkasta locken. 
V. Solståndstiden eller Blomstertiden (Mensis florescentiae L.) varar vid Hernösand från omkring den 20 Juni till omkring den 7 Juli. Vid Upsala varar perioden från första rågax till rågens blomning och innefattar de tre senare veckorna af Juni. Början af perioden inträffar således vid Upsala omkring 12 dagar tidigare, än vid Hernösand; slutet skiljer sig på en vecka. Växtligheten i mellersta Sverige har nu snart hunnit upp växtligheten i sydligare delar af Skandinavien, men först fram emot midten af Juli har dock växtligheten i de förra trakterna fullkomligt hunnit upp växtligheten i sydliga Skandinavien 1). I sydligare delen af Skandinavien börjar perioden tidigare, ju längre mot söder vi komma, i Skåne t. o. m. i slutet af Maj; men slutet af perioden är der liktidigt med periodens slut vid Upsala, »ty den 24 Juni till den 1 Juli, allt efter årens olika beskaffenhet, är växtligheten lika långt framskriden i Skåne och i Upland.» Vi hafva redan förut sett, att i nordliga Skandinavien denna period börjar i Nordlanden vid polcirkeln omkring den 1 Juli och i de nordligaste delarne af Skandinavien omkring eller straxt före medlet

1) För att visa, att växtligheten i mellersta Skandinavien ej förr, än en vecka in i Juli, hunnit lika långt i utveckling, som i södra Sverige vid midsommartiden och omkring den 1 Juli, må det tillåtas förf. att anföra några exempel från sump-Hypna och från Bartramiae. Sump-Hypna och Bartramiae hafva nemligen ej den 1 Juli vid Hernösand, såsom i södra Sverige, fält sina lock, såsom det synes af följande exempel af dessa mossor frân olika trakter af Skandinavien.

Hypnum exannulatum hade vid pressning börjat fälla locken i Södml. $\frac{106}{6} 68$ och hade fält locken i Södml. $\frac{2 n}{6} 68$; i Angml. fällas locken aldrig hos Hypna fluitans och exannulatum före den 1 Juli. Hypnum cuspidatum hade locken qvar i VG. $\frac{9}{6} 73$, hade fält locken i Södml. $\frac{10}{6} 68$, visade vid pressning knappt början till lockfällning vid Trondbjem $\frac{28}{6} 69$. Hypnum cordifolium var i lockfällning vid Hernösand $\frac{4}{7} 74$, men visade vid pressning inga lock i ÖG. $\frac{20}{6} 68$. Amblystegium filicinum fälde vid pressning locken i VG. $\frac{9}{6} 73$, vid Östersund $\frac{23}{6} 70$, i Sk. ${ }_{6} 72$ och i Nordlanden $\frac{7}{7} 69$, men hade $\mathrm{i}$ naturen ej fullt slutat sin lockfällning vid Sundsvall $2 \frac{21}{7}$ senåret 1874. - Bartramia Halleri fälde locken vid pressning vid Östersund

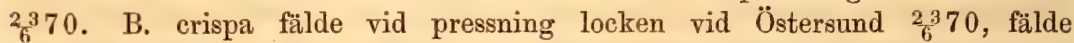
åtminstone några lock vid Stockholm $\frac{3}{6} 64$ och i naturen vid Hernösand $\frac{4}{8} 74$; visade friska frukter utan lock'i Nordlanden ${ }_{7}^{1 / 70},{ }_{7}^{19} 70$ och ${ }_{7}^{69}$ samt i Lapponia orient. $\overline{7} 72$. B. Oederi fälde vid pressning en del lock i Salten $\frac{7}{7} 69$ och vid Östersund $\frac{23}{6} 69$; visade temligen unga frukter vid Sundsvall $\frac{13}{6} 64$; hade friska frukter utan lock i Salten 769 och Ranen 1970. B. ityphylla fälde locken på de flesta frukterna vid Levanger $\frac{24}{6} 69$ och hade i naturen börjat fälla locken vid Hernösand $\frac{4}{7} 74$. 
af Juli. I Nordlanden under polcirkeln slutar perioden omkring en vecka senare, än vid Hernösand, eller omkring den 15 Juli, i ännu nordligare trakter af Skandinavien troligen ännu något senare. Perioden blir allt kortare, ju längre mot norden vi komma; i Skåne varar den litet öfver en månad, vid Upsala omkring 3 veckor, vid Hernösand $2 \frac{1}{2}$ vecka och i Nordlanden troligen knappt 2 veckor ${ }^{1}$ ).

Blomning. Allt flera löfmossor börja nu att blomma, och vid slutet af denna period närmar sig de blommande löfmossornas antal sitt maximum. Ibland de pleurokarpiska mossorna blomma normalt under denna tid Hypnum Heufleri, Brachythecium plicatum, Camptothecium lutescens, Rhynchostegia murale, rusciforme (mot slutet), tenellum (och $\mathrm{i}$ analogi med den sista troligen Rh. depressum och Eurhynchium Teesdalii), Eurh. striatum, Thamnium, Climacium, Antitrichia (mot slutet), Homalothecium, Cylindrothecium, Neckerae (af hvilka dock N. oligocarpa börjat redan under den föregående perioden, N. pumila kanske då redan slutat att blomma och N. Besseri ex analogia, ej enligt exemplar, föres till denna period) samt Pseudoleskea atrovirens. Af dessa hafva största delen redan under den 3:dje perioden fält sina lock. En del af de öfriga under Såningstiden lockfällande arterna börja äfven nu att blomma, men tillhöra med afseende på blomningen mera normalt nästa period, såsom Hylocomia, af hvilka dock H. loreum uteslutande blommar under denna tid, Hypna Schreberi och molluscum samt Brachythecia albicans, glareosum (dessa 2 i södra Sverige mest under denna tid), collinum (i slutet), reflexum, Starkei, Rutabulum, rivulare, populeum och plumosum. Dessutom börja nu att blomma mera samtidigt med fruktmognaden oftast Hyp-

1) För att bevisa rigtigheten af sin härofvan gjorda begränsning af denna period $\mathrm{i}$ Nordlanden, samt äfven för att lemna några exempel på, när samma utveckling af växtligheten återfinnes på olika ställen inom Skandinavien, vill förf. anföra några exempel, utom de redan anförda, från mossornas lockfällning.

Encalypta rhabdocarpa fäller locken vid denna periods början; den började fälla locken på Kinnekulle $\frac{9}{6} 73$, i Ranen vid polcirkeln $5-\frac{1}{7}^{10}$ 70 och vid Bodö $\frac{5}{5} 69$; i Salten vid fjordens innersta vik var lockfällninningen afslutad $\mathrm{i}$ midten af Juli 1869. Splachnum vasculosum tillhör slutet af perioden; denna mossa visade vid pressning nästan intet lock vid Trondhjem $2 \frac{7}{6} 70$; de flesta frukterna voro försedda med lock vid Bodö $\frac{3}{7} 69$; många frukter voro ej ännu fullt utvecklade i Helgeland ${ }_{\gamma}^{1} 70$ och Ångml. 472 ; lockfällningen pågick vid Hernösand $\frac{4}{8} 68$ och $\frac{5}{7} 73$. 
na Sommerfeltii, uncinatum, pratense och stundom Hypnum stellatum samt Amblystegia filicinum och serpens. Från Löfsprickningstiden gå Hypnum cupressiforme, Eurhynchium striatulum, Pylaisia och Platygyrium ofta in i denna period, och Pseudoleskea catenulata fortsätter äfven nu och allt framgent att blomma. De mest utmärkande, nu blommande akrokarpiska mossorna äro Polytricha, Mnia med Cinclidia och Splachna. Polytricha blomma nu och likt dem Pogonatum alpinum, Oligotricha och Catharineae (ibland de sista dock C. tenella blott i Norge, ej i Sverige). Ibland Polytricha tillhöra Pol. commune och piliferum mera perioden i dess helhet; de öfriga Polytricha jemte Pogonatum alpinum tillhöra deremot mera senare hälften af densamma. Bland Mnia blomma tidigast Mn. punctatum, subglobosum och hornum och senast Mn. cinclidioides, cuspidatum och stellare. af hvilka de 2 sista kunna blomma ännu i början af nästa period; Cinclidia tillhöra äfven slutet af denna tid. Splachna samt likt dem Tetraplodon mnioides och Dissodon splachnoides blomma oftast nu, men kunna äfven under nästa period, i synnerhet de 2 sista, finnas med mogna blommor. För öfrigt blomma under Solståndstiden Conostomum, Mielichhofferia, de på jord växande Tortulae squarrosa, unguiculatae (utom icmadophila), de på murar och klippor växande Tortulae muralis och revoluta, Trichostoma rigidulum, tophaceum och mutabile, Leptotricha glaucescens (i Nordlanden) och tortile $\boldsymbol{\beta}$ pusillum, Stylostegium, Dicranella squarrosa, Dichodontium, Cynodontium Bruntoni, Weissiae (Microweissiae i början, Euweissiae under perioden $\mathrm{i}$ dess helhet och Rhabdoweissiae $\mathrm{i}$ slutet), Anoectangium och Gymnostoma. Bland Brya är dessutom de blommande arternas antal nu temligen stort; sålunda blomma nu Zieriae, de på jord växande Weberae albicans, carnea, pulchella, Ludwigii och annotina (samt i analogi med dessa troligen Brya atropurpureum och Klinggraeffii), de på klippor växande Weberae cruda, elongata och longicolla; mot slutet af perioden börjar slutligen blomningen hos en stor del arter, såsom hos Brya cirrhatum, intermedium, caespiticium, alpinum (hos den sista mera undantagsvis), erythrocarpum, inclinatum och pendulum, samt hos Brya pallens, oeneum, uliginosum, Brownii, purpurascens och arcticum. Ibland de Orthotricha, som redan under den föregående perioden börjat blomma, slutar nu O. fastigiatum; Orthotricha speciosum, rupestre, obtusifolium och anomalum fortsätta äfven in i nästa period; O. lejocarpum, Schimperi, pumilum och Sturmii blomma nu normalt, och 0 . alpestre börjar i slutet. Dessutom blomma nu Ulotae Drummondii och Ludwigii, 
samt mest mot slutet U. curvifolia och Hutchinsiae. Grimmiae och Racomitria tillhörde egentligen Löfsprickningstiden; Grimmiae commutata och montana samt Racomitrium protensum blomma dock ibland under denna tid; Gr. Donnii och Rac. ellipticum synas blomma nu normalt och likt den förra Gr. ovata, då den ej blommar under Såningstiden; slutligen tillhöra gränsen till nästa period Grimmiae maritima, apocarpa, conferta, leucophaea och den närslägtade Hedwigia. Bland de till gränstiderna hörande akrokarpiska mossorna hafva vi redan vid den föregående perioden omnämnt de på gränsen till denna blommande akrokarpiska mossorna, och vilja vi endast tillägga att Encalyptae, hvilkas normala blonmingstid sammanfaller med Löfsprickningen, stundom äfven $\mathrm{i}$ början af denna tid finnas blommande. På gränsen till nästa period blomma deremot Amblyodon, Amphoridium lapponicum, de ofvannämnda Grimmiae, Hedwigia, Trichodon, Ceratodon, Didymodon rubellus, Blindia samt Dicrana fragilifolium, strictum, viride, Blyttii och likt den sista Dicr. Starkei, albicans, fulvellum, Anderssonii och hyberborum; dock blir blomningstiden hos de alpina Dicrana genom deras höga räxtlokal ofta ganska långt framskjuten. Slutligen kunna stundom Bartramiae, t. ex. B. ityphylla och Oederi, samt Meesia uliginosa börja blomma i slutet af denna period, fastän de efter regeln tillhöra den nästa.

Fruktmognad. Det största antalet af de till denna tid hörande pleurokarpiska mossorna äro kärr- och vattenmossor, af hvilka, förutom Rhynchostegium rusciforme och undantagsvis Fontinales antipyretica och gracilis, inga under den föregående delen af året fält locken. Kärrmossorna fruktsätta mest i senare hälften af denna period, såsom Hypna stellatum, chrysophyllum, cordifolium, giganteum, sarmentosum, cuspidatum, trifarium, commutatum, pratense och Lindbergii, Harpidia, Camptothecium nitens samt Amblystegia riparium och filicinum. En del af de uppräknade sumpmossorna fälla dock ofta locken äfven under nästa period, och komma dessa att vid denna närmare omnämnas på samma gång som de pleurokarpiska kärrmossor, som mera uteslutande tillhöra nästa period. De under denna tid fruktsättande vattenmossorna tillhöra mera perioden $i$ dess helhet, ej blott slutet, och äro Limnobia samt Amblystegia fluviatile och irriguum. Dessutom börja äfven stundom Fontinales antipyretica och gracilis att nu fälla locken. Öfriga under denna tid lockfällande pleurokarpiska mossor äro Hypnum Sommerfeltii, Amblystegia radicale (enl. förff.) och serpens, hvilken sista väl visar mogna fruk- 
ter hela sommaren igenom, men nu har sin normala lockfällningstid, Rhyncostegium tenellum, Eurhynchium Teesdalii, Thujidium delicatulum, hvilken sista börjar fälla locken i slutet, Heterocladiam Kurrii (enl. förff.), samt Plagiothecia Mühlenbeckii och nitidulum, hvilka 2 sista i slutet börja fälla locken i Norge, ej i Sverige.

Ibland de akrokarpiska mossorna äro, åtminstone i de nordligare delarne af Skandinavien, Splachna genom sina sköna frukter de mest karakteristiska för denna tid. Alla Splachnum-arter, likasom äfven Dissodon splachnoides, fälla nu normalt sina lock; endast i undantagsfall kunna hos dessa, t. ex. hos Spl. ampullaceum och sphaericum, frukterna mogna först under nästa period. Äfven många andra jordmossor äro för denna tid utmärkande. Bland dessa, intaga de mest på jord växande, vackra Mnia och likt dem de i kärr växande Cinclidia ett framstående rum; bland Mnia fruktsätta nemligen de flesta på gränsen mellan den föregående perioden och denna; Mn. Blyttii, rostratum, cuspidatum, hornum, spinosum, serratum och stellare fälla dock locken mera eller mindre lingt fram in i lenna period, de 2 sista till och med i slutet, likasom Cinclidia. Brya börja nu äfven framvisa en och annan art med mogna frukter såsom $\mathrm{Br}$. atropurpureum, Klinggraeffii, Funckii och troligen mot slutet Bryum cyclophyllum. Andra Brya börja åtminstone nu att fälla locken, såsom $\mathrm{Br}$. cirrhatum, turbinatum, caespiticium och lacustre samt Weberae nutans och cucullata, för att i nästa period mera normalt fa mogna frukter. Ett par arter, Brya Warneum och calophyllum, fruktsätta 2 gånger på året, och infaller nu för dem den första lockfällningen. Andra denna tid tillhörande jordmossor äro Funariae fascicularis, Ahnfeltii och calcarea, (den sista mest mot slutet), Encalypta vulgaris (i början), Tortulae squarrosa, cylindrica, Hornschuchii och revoluta (alla Tortulae förnämligast enligt förff,), Trichodon, Ceratodon, Campylopi, Archidium, Sporledera, och slutligen går äfven ibland Phascum bryoides in i denna period. Polytrichum piliferum och Tetraphis börja äfven fälla locken i slutet af denna tid, och nu träffas på ruttna stubbar Buxbaumia indusiata med mogna frukter. Bland klippmossorna äro Bartramiae de för denna tid mest utmärkande, meu dessutom fällas nu locken af Encalypta rhabdocarpa (i början mest), Racomitria lanuginosum och fasciculare, Blindia, Fissidens pusillus, Gymnostomum curvirostre samt af Dicrana Blyttii, falcatum, Starkei, hyperboreum, Anderssonii (den sista enligt förtf.) och troligen ex analogia af $\mathrm{D}$. fulvellum, ehuru denna art, likt 
öfriga alpina Dicrana, på sin höga växtlokal vanligen tillhör en långt senare tid, än den, då denna period infaller i låglandet. I slutet af perioden äro Seligeriae diversifolia, acutifolia, recurvifolia, pusilla och tristicha $\beta$ patula som vackrast. I slutet börja äfven Tortulae muralis, laevipila, princeps, ruralis och intermedia, Dicranum spurium samt Cynodonti: Bruntoni, polycarpum och gracilescens att fälla locken. Bland Orthotricha tillhöra slutligen denna tid O. rupestre, fastigiatum, Rogeri (enligt förff.), cupulatum och Sturmii; ifrån föregående period gå följande in $\mathrm{i}$ början af denna, nemligen 0 . urnigerum, tenellum, laevigatum och anomalum, och följande arter börja nu fälla locken för att mera normalt tillhöra nästa period, nemligen O. speciosum, affine, stramineum, Schimperi och pumilum.

VI. Karttiden eller Illögsommaren (Mensis grossificationis L.) Börjar i mellersta Skandinavien, eller vid Hernösand, omkring den 7 Juli och slutar omkring den 24 Juli. Under denna period upphinner växtligheten derstädes växtligheten i sydligare delar af Skandinavien, och omkring den 24 Juli, eller vid slutet af perioden, torde växtligheten $\mathrm{i}$ hela Skandinavien hafva hunnit till lika utveckling, undantagandes på högfjällen och möjligen i de nordligaste delarne. Vid Upsala varar perioden från Sedi acris börjande till dess afslutade blomning och innefattar ungefär tiden mellan den $1 \mathrm{Ju}-$ li och den 24 Juli. I sydligare delar af Skandinavien sammanfalla gränserna i det närmaste med gränserna vid Upsala. Äfven $i$ nordligare delar af Skandinavien hinner under denna tid växtligheten att komma $\mathrm{i}$ jemnbredd med växtligheten $\mathrm{i}$ de sydligare delarne; i Nordlanden börjar sålunda perioden omkring midten af Juli och slutar samtidigt med slutet i sydligare trakter eller ett par dagar senare. Äfven på fjällen ofvan buskregionen närmar sig nu i de nedre delarne af lafbältet växtligheten låglandets i utveckling. Af föregående gränsbestämningar för denna period se vi, huru mycket snabbare utvecklingen är, ju längre vi komma mot norden, hvarföre äfven perioden blir allt kortare, ju längre mot norr vi komma ${ }^{1}$ ).

1) För att visa det berättigade $\mathrm{i}$ begränsningen af denna period och för att lemna en jemförelse af utvecklingens gång under denzamma inom Skandinavien anföras härnedan några exempel från löfmossornas lockfällning. Webera cruda hade vid pressning fält blott ett par lock i Södml. $\frac{20}{5} 68$; visade vid pressning lockfällning $\mathrm{i} \mathrm{OOG}_{7} 69$, Ångml. $\frac{177}{7} 74$, Ranen i Nordlanden $\frac{6}{7} 70$ och i Salten på nảgon höjd öfver hafvet $\frac{26}{7} 69$; i naturen funnos locken ännu quar i Ảngml. och Mdpd $207^{22}$ under senåret 1874. Af dessa uppgifter synes det, att $i$ början af Juli växtligheten $i$ 
Blomning. Under denna tid uppnår de blommande löfmossornas antal sitt maximum, och tanken svindlar nästan, då den söker göra klar för sig den oerhörda lifaktighet, som nu råder uti i naturen inom mossornas rike. Då regn eller riklig dagg fallit, torde vandraren under denna tid vid hvarje fotsteg ute i naturen sätta sina fötter på tusentals svärmande antherozoider. Ibland de pleurokarpiska mossorna blomma nemligen nu en stor del af de under Såningstiden lockfällande arterna. Sålunda blomma nu de fiesta Hylocomia, af hvilka H. umbratum, Oakesii, brevirostre och triquetrum började redan i slutet af föregående period att blomma och fortsätta dermed in till midten af denna och $\mathrm{H}$. splendens normalt tillhör perioden i dess helhet, Hypnum Schreberi, Brachythecia, af hvilka dock en del arter kunna börja att blomma redan under Solståndstiden och några äfven finnas blommande under nästa period, hvilka undantagsfall vid dessa perioder äro omnämnda, Cylindrothecium (i början), Leucodon, Habrodon, Pterogonium (de 2 sista ex analogia), Anomodon-arterna (mest i slutet) och Hookeria. Andra pleurokarpiska mossor blomma nu nästan samtidigt med lockfällningen, såsom Limnobia (L. arcticum tillhör dock nästa period enligt exemplar från Nordlanden), Amblystegium riparium (och likt den sista troligen A. trichopodium och Kochii), Plagiothecia piliferum och Mühlenbeckii (de 2 sista blott i Nordlanden), Thujidium delicatulum och Fontinalisarterna, af hvilka F. antipyretica fortfar att blomma äfven under nästa period. $\mathrm{Nu}$ blomma äfven helt normalt Hypna stellatum, commutatum och pratense samt Amblystegium filicinum, ehuru de öfriga egentliga sump-Hypna normalt tillhöra nästa 3 perioder och oftast den 8:de. Från föregående period gå ofta Hypnum molluscum, Rhynchostegium rusciforme, Climacium, Camptothecium lutescens, Eurhynchium striatum och Homalothecium in $\mathrm{j}$ denna, och från samma period fortfara ända till de följande perioderna Hypnum uncinatum, Amblystegium serpens och Pseudoleskea cate-

mellersta och nordliga Skandinavien är något efter sydliga Skandinaviens i utreckling, men håller den då derstädes på att hinna upp växtligheten $\mathrm{i}$ sydligare trakter. - Detsamma framgår äfven med lätthet från följande exempel. Tortula ruralis visade nemligen frukter med lock i Ångml. $\frac{8}{6} 69$; locken vid pressning affallande i Ångml. ${ }_{6}^{29} 74$, få lock qvar i Nordlanden 2070 och ÖG. ${ }_{7}^{24} 70$, alla locken fälda i Mdpd 2174 . Tortula tortuosa visade utom fjolårs-frukter mycket unga, gröna årsfrukter i VG. $\frac{6}{6} 73$, vid pressning knappt börjad lockfällning i ÖG. $\frac{1}{7} 68$, lockfällning i Nordlanden 2670 . 
nulata att blomma. Slutligen börjar nu blomningen hos Hypnum hamulosum.

Annu mera talrika äro de nu blommande akrokarpiska mossorna. Bland klipp- och stenmossorna blomma Breutelia, Bartramiae (mest i midten och mot slutet), Zygodon, Ptychomitrium, Tortulae tortuosa (och troligen, likt den sista, T. inclinata och fragilis) samt icmadophila, Desmatodontes latifolius, systylius och obliquus (den sista i slutet), Distichia, Didymodon rubellus samt Cynodontia polycarpum och gracilescens. Bland jordmossorna märkas nu Discelium, Funariae fascicularis och Ahnfeltii, Physcomitrium (och troligen likt den sista Pyramidula), Dissodon Frölichii, Tortulae norvegica och convoluta, Trichostomum crispulum, Didymodon cylindricus, Pottia latifolia, Campylopi och Dicranodontia. Dessutom tillkomma de i kärr och vatten växande Meesiae, Cinclidotus och Leucobryum, samt den på träd växande Tortula latifolia. Bland Brya blomma de flesta under denna period; de, som började blomma redan $i$ slutet af föregående period och vid denna uppräknades, fortsätta att blomma mer eller mindre långt in i denna tid; dessutom blomma nu Brya Duvalii, bimum, microstegium, turbinatum, cyclophyllum, lacustre, Marratii och mamillatum, Weberae polymorpha och acuminata samt Leptobryum; i slutet börja deremot Brya pseudotriquetum, pallescens, subrotundum, Mühlenbeckii och alpinum mera normalt. Bland Orthotricha hafva nu endasst 0 . Lyellii och alpestre sin rätta blomningstid; de öfriga hafva nu mest slutat att blomma; endast 0 . speciosum, rupestre, pumilum, Schimperi, obtusifolium och anomalum samt Ulota Hutchinsiae träffas nu dessutom mera undantagsvis med mogna blommor. Dicrana äro deremot mycket utmärkande för denna tid genom sina oftast $n u$ fullt utvecklade blommor; redan vid föregående period omtalades de på gränsen till denna blommande arterna; under denna tid blomma Dicrana spurium, robustum, undulatum, scoparium och fuscescens, af hvilka alla, utom den första arten, äfven fortsätta med sin blomning in i nästa period; ibland de öfriga arterna blomma de flesta på gränsen till nästa period eller under densamma och komma att vid densamma omnämnas. I fråga om Dicrana undulata och scoparia får dock förf. erinra derom, att det endast är i Sverige, som de tillhöra denua period och den nästa; i Nordlanden tillhöra troligen dessa Dicrana Såningstiden. De till gränsen mellan föregående period och denna hörande akrokarpiska mossorna hafva vi redan vid föregáende period omtalat; från Solståndstiden gå dessutom stun- 
dom in i denna Polytricha (utom P. commune och piliferum), Mnia stellare och cuspidatum, Splachna, Tetraplodon mnioides, Grimmiae Donnii och ovata samt Racomitrium protensum. På gränsen mellan denna period och den följande blomma Diphyscium, Catharinea tenella i Sverige, Philonotis calcarea, Racomitria lanuginosum och fasciculare, Tortula ruralis (och likt den sista troligen äfven T. princeps, intermedia och laevipila), Pottia truncata (och i likhet med densamma troligen P. lanceolata, Starkei, intermedia och cavifolia) samt Seligeriae recurvata och tristicha (och likt de sista troligen S. diversifolia, pusilla, acutifolia och crassinervis). Hvad de kleistokarpa mossorna vidkommer, är förf. snarast hugad att tro dem tillhöra gränsen mellan denna period och den följande, emedan de böra blomma samtidigt med en del andra späda jordmossor, t. ex. Pottiae. Förf. har tyvärr ej haft tillfälle att $\mathrm{i}$ naturen studera dessa mossors blomningstid, och $\mathrm{i}$ samlingar finnas af dem aldrig exemplar med friska blommor.

Fruktmognad. Kärrmossorna äro äfven för denna tid de mest karakteriserande pleurokarpiska mossorna och nästan de enda af denna afdelning, som nu fruktsätta. Några arter, som stundom redan i slutet af Solståndstiden började fälla locken, tillhöra oftast äfven början af denna tid, såsom Hypna stellatum, chrysophyllum, trifarium, pratense, Lindbergii, lycopodioides, intermedium och scorpioides, Camptothecium nitens samt Amblystegia riparium och filicinum. Andra kärrmossor börja ej fälla locken förr än nu, såsom Hypna elodes, stramineum och polygamum, Amblystegia trichopodium och Kochii samt Thujidium Blandowii. Mot slutet börja dessutom normalt de $\mathrm{i}$ vatten växande Fontinalis-arterna att visa mogna frukter. Bland de öfriga pleurokarpiska mossorna fruktsätta nu endast ytterst få; mest utmärkande äro Plagiothecia silesiacum och turfaceum samt Plag. Mühlenbeckii, nitidulum och piliferum, hvilka 3 sista blott i Nordlanden, eller Pl. piliferum stundom äfven i Sverige, fälla sina lock under denna tid. Dessutom går Thujidium delicatulum in i denna period, fortfar Amblystegium serpens ännu att fälla locken, och börjar Hypnum uncinatum nu att fälla desamma.

Splachna äro äfven nu de mest i ögonen fallande akrokarpiska mossorna, dock vanligen ej genom lockfällningen, utan genom sina isynnerhet efter fruktmognaden starkt utvecklade och vackra fruktbihang; Splachna sphaericum och ampullaceum finnas dock ännu ofta med lock, likasom Dissodon splachnoides; Tetraplodon mnioides och Tayloria serrata börja deremot först nu att 
visa mogna frukter. Äfven bland de akrokarpiska mossorna tillhöra några kärr-innevånare denna tid, såsom Polytrichum gracile, Meesiae, Amblyodon, hvarförutom Cinclidia gå in i denna period, och Philonotis-arterna samt Gymnocybe palustris i slutet börja fälla locken. Bland jordmossorna märkas nu Diphyscium, några Polytricha (nemligen $\mathrm{P}$. piliferum i början, mera mot slutet $\mathrm{P}$. juniperinum och strictum), Physcomitrium, Tortulae norvegica (enligt förff.), subulata, mucronifolia och convoluta, Desmatodontes latifolins och systylius, Trichostomum crispulum, Pottiae latifolia och Heimii samt Archidium. Funaria calcarea går äfven ibland in i början af denna tid, och Desmatodontes Laureri och obliquus börja stundom i slutet af perioden att fälla locken. Många stenoch klippmossor träffas nu äfven med vackra, mogna frukter, såsom Timmia bavarica, Encalyptae ciliata och brevicolla (den sista vid Upsala, ej i Norrland), Amphoridium Mougeottii, Tortulae princeps, ruralis, intermedia, (laevipila), tortuosa, fragilis (enligt förff.) och muralis, Leptotricha glaucescens och flexicaule, (Eucladium enligt förffi.), Dicranum robustum, Cynodontia Bruntoni, polycarpum och gracilescens samt Gymnostomum tenue. Från föregående period gå dessutom Blindia och Dicranum spurium in i början af denna; $i$ slutet börja deremot Conostomum, Distichium capillaceum och Didymodon rubellus att fälla locken. Bland Brya höra till denna tid Brya Duvalii, pallescens, subrotundum, cirrhatum, turbinatum, caespiticium, lacustre, Weberae nutans, cucullata och cruda samt Leptobryum. Andra börja i slutet få mogna frukter, såsom Brya pseudotriquetrum, pendulum och inclinatum samt Weberae longicollis och elongata, hvilka alla tillhöra gränsen mellan denna period och den nästa eller början af den nästa. Normalt till denna tid höra dessutom Orthotricha speciosum, affine, alpestre, stramineum, Schimperi och pumilum samt Ulotae Hutchinsiae och curvifolia. Slutligen fruktsätta nu Tetraphis och, enligt förff., Dicrana strictum och viride.

VII. Slattertiden (Mensis maturationis L.). Denna period börjar ungefär liktidigt $\mathrm{i}$ hela det Skandinaviska låglandet, eller med den sista veckan af Juli. Slutet är äfven liktidigt och infaller omkring den 15 Augusti samt utmärkes genom Succisae börjande hlomning. För mellersta Sverige är väl detta den naturligaste slutgräns, som kan uppställas. Från slåtterns slut kan der slutgränsen ej tagas, emedan slåttern på landsbygderna fortsättes långt in på senhösten; ej heller kan skördens början blifva 
en naturlig gräns, emedan den der börjar först efter den 20 Augusti, och denna slutgräns vore allt för sen. Den 15 Augusti är kanske redan en allt för långt framskjuten gräns, hvilket ses af sump-Hypnernas nu börjande blomning i mellersta Skandinavien, hvilken infaller först i nästa period i sydligare delar af Skandinavien. Förf. har dock ej kunnat finna någon annan, bättre slutpunkt för perioden i mellersta Skandinavien. Vid Upsala angifves perioden vara från Sedi albi börjande blomning till Scabiosae Succisae och innefatta sista veckan af Juli och de 2 första veckorna af Augusti. I sydligare delar af Skandinavien äro gränserna ungefär desamma, som vid Upsala, eller borde kanske slutet något framflyttas i de sydligaste delarne. I de nordligare delarne af Skandinavien infaller denna tid äfven på samma tid, som i det öfriga Skandinavien, eller torde perioden der sluta något före den 15 Augusti. Till och med på fjällen upphinner växtligheten, åtminstone uppe $\mathrm{i}$ videbältet, under denna tid i utveckling upp vegetationen $\mathrm{i}$ låglandet ').

Blomning. Med slåttertiden sluta löfmossorna att mera allmänt blomma, men under densamma är de blommande löfmossornas antal ännu mycket stort. Isynnerhet äro de nu blommande pleurokarpiska mossorna ytterst talrika. Ibland dem hafva vi några, som redan under Såningstiden fälde sina lock, men som ej blomma förr än nu, såsom Hylocomia squarrosum och subpinnatum, Brachythecia (af hvilket slägte dock de flesta normalt blommade under den föregående perioden, men en del dock stundom träffas med mogna blommor äfven nu, såsom det är fallet mera normalt med Br. salebrosum, trachypodium och glaciale, mera undantagsvis med $\mathrm{Br}$. velutinum, populeum och plumosum), Eurhynchia praelongum, Schleicheri, Stokesii och crassinerve (alla dessa mest i början) samt mera under perioden i dess helhet Eurh. piliferum, Vaucheri och (ex analogia) Eurh. velutinoides,

1) Polytricha formosum och commune samt Pugonatum alpinum äro isynnerhet genom sin lockfällning utmärkande för början af denna period och fälla äfven locken samtidigt öfver hela Skandinavien i låglandet. Sålunda fälde dessa arter sina lock $\mathrm{i}$ Nordlanden omkring den 1 Augusti 1870, likasom de alltid $i$ Ångml. och sydligare delar af Skandinavien normalt fälla sina lock vid denna tid. Pogon. alpinum $\beta$ septentrionale fälde t. o. m. i Nordlanden locken den $\frac{970}{8}$ vid öfver 3000 fot öfver hafvet, hvilket dock är ovanligt; denna varietet brukar nemligen på högfjällen, om dess frukter hinna till mognad, ej fälla sina lock före slutet af Augusti. 
Lescuraea, Thujidium tamariscinum och abietinum (den sista mest i början), samt äfven i början Heterocladium heteropterum. Andra blomma nu mera samtidigt med lockfällningen, såsom Нypna arcticum (i Nordlanden) och incurvatum, Amblystigia enerve, confervoides, Sprucei och subtile, Plagiothecia (af hvilka Pl. silesiacum och turfaceum sluta blomma i början, deremot Pl. laetum i Nordl., piliferum i Ångml. och nitidulum på båda dessa ställen nu börja blomningen och, utom $\mathrm{Pl}$. laetum, fortsätta dermed in i nästa period), Pterigynandrum, Myurellae och Dichelyma-arterna. Från förra månaden fortfara Hypna uncinatum och hamulosum, Amblystegium serpens, Pseudoleskea catenulata och stundom Fontinales att blomma äfven under denna. En del andra pleurokarpiska mossor börja nu att blomma och fortsätta dermed mer eller mindre långt in i nästa period, nemligen Hypna callichroum, purum, Crista castrensis, Orthothecia och Heterocladium dimorphum, hos hvilka alla blomningstiden, utom hos den första, infaller på gränsen mellan denna period och den nästa. De i kärr växande pleurokarpiska mossorna, hvilka fälde locken i slutet af Solståndstiden eller under Karttiden, börja äfven nu, isynnerhet i de mellersta och nordliga delarne af Skandinavien, att blomma; $\mathrm{i}$ de sydligare delarne af Skandinavien blomma dessa mossor vanligen först i nästa period. Redan $\mathrm{i}$ den 5:te perioden började bland dessa mossor Hypna stellatum, pratense (i södra Sverige) och Amblystegium filicinum att blomma, och $\mathrm{i}$ den 6 :te perioden började Hypnum commutatum och Amblystegium riparium blomningen. Bland dessa hafva Amblystegia nu oftast afslutat sin blomning; bland de öfriga tillhör Hypnum pratense i Ångml. denna period; Hypna stellatum och commutatum blomma äfven nu och i södra Sverige till och med ibland i nästa period. Bland de öfriga sump-Hypna blomma nu $\mathrm{i}$ de nordligare delarne af Skandinavien Hypna polygamum, cordifolium, giganteum, stramineum, fluitans, exannulatum, revolvens, scorpioides, Lindbergii och mot slutet Thujidium Blandowii. Äfven i södra Sverige börjar nu blomningen hos Hypna chrysophyllum, stramineum, scorpioides, intermedium, revolvens och Amblystegium irriguum.

Ibland de akrokarpiska mossorna hafva de blommandes leder nu betydligt glesnat. Under denna tid blomma dock bland dem följande, af hvilka de flesta växa på jord, nemligen Buxbaumiae (troligen i början), Philonotes, Catoscopium, Funaria, Dissodon Frölichii, Desmatodontes Laureri och troligen cernuus, Leptotricha glaucescens (i Angml.), homomallum och pallidum, Fissidens- 
arterna (isynnerhet i början) samt Trematodon brevicollis. Orthotrichum pulchellum synes äfven blomma nu enligt det exemplar, förf. undersökt, men troligen tillhör dock denna art någon af de tidigare perioderna, likt dess samslägtingar. De på gränsen till denna period blommande akrokarpiska mossorna hafva redan vid föregående period, blifvit omnämnda; förf. vill blott tillägga, att Racomitria lanuginosum och fasciculare mest tillhöra början af denna period, och att bland Seligeriae S. Donnii blommar nu i södra Sverige, men mest i nästa period i Nordlanden. Dessutom gå ofta Bartramiae samt Cynodontia gracilescens och polycarpum in i denna period. $P_{a}^{\circ}$ gränsen till den nästa blomma Paludella, Tayloria serrata, Tortulae alpina, squarrosa, subulata och mucronifolia. Serskildt förtjenar slutligen blomningen hos Brya och Dicrana att omnämnas. Brya hafva nu oftast afslutat sin blomning; Brya Mühlenbeckii, alpinum, capillare och Marratii blomma dock nu; Brya pseudotriquetrum, pallescens, subrotundum och Duvalii gå ofta in i perioden och tillhöra gränsen till densamma. Dicrana äro deremot, åtminstone i Sverige, de för denna tid mest utmärkande, blommande akrokarpiska mossorna; bland dem tillhöra nemligen Dicrana undulata (utom spurium), scoparia, Sauteri, longifolium, montanum samt troligen Scottianum och fulvum i Sverige antingen början af denna period eller perioden i dess helhet. Det är derför isynnerhet i början af denna tid, som de för en del af de större Dicrana utmärkande, flygtiga dvärghanplantorna äro att söka.

Fruktmognad. De i kärr växande pleurokarpiska mossorna hafva nu afslutat sin fruktmognad; endast Thujidium Blandowii träffas stundom ännu i början af denna period lockbärande. De till denna tid hörande pleurokarpiska mossorna växa mest på stenar och klippor eller ibland på trädrötter, såsom Hypna incurvatum, Heufleri (enligt förff.), callichroum, hamulosum, fastigiatum (i nordliga Skandinavien), Amblystegia enerve, confervoides, subtile och Sprucei, Pterigynandrum (i Sverige), Plagiothecia laetum och piliferum (den sista mest i Norge, sällan i Sverige), (Pseudoleskea catenulata enligt förff.), Myrinia, Leskeae och Myurellae. Dessutom infaller nu oftast och åtminstone mest normalt fruktmognaden för de i rinnande vatten växande Dichelyma- och Fontinalis-arterna. Plagiothecia silesiacum och turfaceum gå äfven ibland, fast föga långt, in i denna period, och Hypnum uncinatum samt Amblystegium serpens fortsätta äfven nu med att alstra mogna frukter. 
Talrikare, än de pleurokarpiska, äro de nu fruktsättande akrokarpiska mossorna. Isynnerhet äro Polytricha commune, formosum och alpinum genom sin allmänna förekomst och sitt uppträdande $\mathrm{i}$ stor mängd utmärkande för denna tid. $\mathrm{Nu}$ fällas dessutom locken af följande jordmossor: Funaria hygrometica, Oedipodium, Dissodon Frölichii samt Desmatodon cernuus; från föregående period gå bland dem in i denna: Tortulae subulata och mucronifolia, Pottiae Heimii och pilifera, samt Desmatodontes Laureri och obliquus; Trematodon-arterna börja deremot sällan fälla locken redan i slutet af denna tid. Catoscopium och Paludella äro bland kärrmossorna utmärkande för perioden $\mathrm{i}$ dess helhet, och i början af densamma fällas ofta locken ännu af de äfven mest i kärr växande Philonotes, Gymnocybae och Meesiae. Sten- och klippmossorna visa nu vackra frukter hos Timmia austriaca, Encalyptae streptocarpa, procera, apophysata, commutata och ciliata (den sista mest i början), Stylostegium, Dicranum hyperboreum, Seligeria tristicha (i Nordlanden) och Seligeria Donnii (i Vestergötland); i början af denna period träffas dessutom ännu ofta Didymodon rubellus och Conostomum med lock, och Cynodontia Bruntoni, polycarpum och gracilescens sluta nu sin lockfällning. Äfven många Brya fälla nu locken, såsom Br. bimum (i början mest), microstegium (enligt förff.), (Mildei?), Mühlenbeckii, alpinum, erythrocarpum, capillare, Marratii, mamillatum (i början) och oeneum, samt Weberae annotina (enligt exemplar, ej enligt förff.) och Schimperi; till gränsen mellan den föregående perioden och denna höra dessutom Brya pseudotriquetrum, pendulum och inclinatum samt Weberae longicollis och elongata, af hvilka isynnerhet de 3 första ofta fortsätta att fälla locken långt in $\mathrm{i}$ denna period; slutligen träffas ett och annat Bryum, som normalt fäller locken under Karttiden, ibland undantagsvis i lockfällning äfven under denna tid, såsom Brya pallescens, subrotundum, cirrhatum och lacustre, Weberae nutans och cucullata samt Leptobryum. Orthotricha hafva nu mest slutat att fälla locken; endast 0 . Lyellii tillhör regelbundet denna tid; dessutom gå ofta 0 . speciosum, affine och stramineum in $\mathrm{i}$ perioden. Periodens mest $\mathrm{i}$ ögonen fallande, fruktsättande mossor äro dock, utom Polytricha, torfmossorna (Sphagna), hvilka nu börja att vanligen rikligt få mogna frukter, och derför, ehuru ej hörande till löfmossorna, äfven torde få nämnas vid denna period. 


\section{Skördetiden (Messis L.) och IX Vftersommaren} (Mensis disseminationis L.). Dessa 2 perioder har förf. sett sig trungen att sammanslå till en i mellersta Skandinavien, eller vid Hernösand, under namn af Skördetiden eller Eftersommaren, hvilken här varar från omkring den 15 Augusti till löffällningens början omkring den 15 September. I Hernösandstrakten börjar nemligen skörden omkring den 20 Augusti och slutar först omkring den 10 September, då redan ofta de första löfven börja falla eller åtminstone börjat gulna. Någon eftersommar efter skördetiden med träden ännu gröna finnes ej der, såsom i sydligare delar af Skandinavien. Skördetid och Eftersommar finnas derföre blott såsom liktidiga i det mellersta Sverige, i södra Sverige utgöra de deremot 2 från hvarandra skilda perioder. Förf. har så mycket mera ansett sig berättigad att sammanslå dessa 2 perioder till en vid sin framställning af löfmossornas kalendarium, som mossvegetationen under hela denna tid visar sig så lika, att det vore svårt att, om afseende fästas på mossornas blomning och fruktsättning, finna några väsendtliga skiljaktigheter mellan 2 perioder. De 2 perioderna omfatta vid Upsala den förra tiden från midten af Augusti till omkring den 8 September och den senare tiden från omkring den 8 September till denna månads slut. Skördetiden eller Eftersommaren varar sålunda i mellersta Sverige omkring en kalendermånad och svarar mot de 2 perioderna Skördetiden och Eftersommaren vid Upsala, hvilka tillsammans vara omkring $1 \frac{1}{2}$ månad. Ju längre vi komma söderut, desto längre vara dessa 2 perioder. I Skåne synes dock löffällningen stundom kunna börja redan i de första dagarne af Oktober, i vanliga fall torde den dock derstädes något framskjutas, så att dessa 2 perioders sammanlagda längd der blir nära 2 månader. Redan i början af Augusti hade deremot växtligheten i norra och mellersta Skandinavien i utveckling hunnit om växtligheten i sydligare delar af Skandinavien. Detta blir märkbarare, ju längre fram mot hösten och ju längre mot norden vi komma. Redan nu felas dock förf. material för att kunna bestämdt angifva slutgränsen för denna tid för någon nordligare punkt af Skandinavien, än för Hernösand, hvarföre förf. får inskränka sig till att omnämna, att ju längre mot norden vi komma, desto tidigare infaller slutet af denna tid, uppe vid polcirkeln troligen straxt efter den 1 September. Ju längre mot norden vi komma, desto omöjligare blir det äfven att kunna mellan Slåttertiden och Löffällningen inflicka mera än en period. 
Blomning. Ännu under denna tid blomma ganska många löfmossor, men nu afsluta också dessa mossor nästan fullständigt sin blomning. Ibland de pleurokarpiska mossorna är det mest de i kärr växande arterna, som nu blomma, och är detta isynnerhet fallet med dessa mossor i sydligare delar af Skandinavien. Sålunda blomma nu derstädes Hypna stellatum, polygamum, giganteum, cordifolium, cuspidatum, commutatum (stundom), fluitans, exannulatum, aduncum, intermedium, vernicosum, samt Amblystegia irriguum och fluviatile. I mellersta och nordliga Skandinavien hafva en stor del af dessa mossor redan blommat ut under Slåttertiden; in i denna tid, åtminstone in i början, gå dock derstädes Hypna sarmentosum, badium, Lindbergii och Thujidium Blandowii. Bland kärrmossorna har dock blomningstiden ej blifvit närmare eller åtminstone endast föga undersökt hos Hypna chrysophyllum, elodes, pseudostramineum, trifarium, lycopodioides, Sendtneri och Camptothecium nitens. Dessa torde dock, likt sina samslägtingar, normalt blomma i södra Skandinavien under denna tid, i mellersta och norra Skandinavien under Slåttertiden. Utom de förutnämnda, som voro kärr-innevi̊nare, blomma nu följande pleurokarpiska mossor: Hypna Halleri (i Nordlanden), rugosum (i början), Haldanii, Bambergeri, fastigiatum (i nordliga Skandinavien), pallescens (mest i början), Myrinia (mest i början), Leskea polycarpa samt Plagiothecia, af hvilket slägte Pl. undulatum, denticulatum, silvaticum och nitidulum blomma nu i hela Skandinavien, Pl. piliferum och Mühlenbeckii blomma nu blott i Sverige. In i början af denna tid gå från sista slutet af förra perioden Hypna purum och Crista castrensis, Orthothecia (isynnerhet intricatum) och Heterocladium dimorphum. Dessutom fortfara tills nu, men afsluta under denna tid sin blomning, de mest hela sommaren blommande Hypna uncinatum och callichroum, Amblystegium serpens samt Pseudoleskea catenulata.

De nu blommande akrokarpiska mossorna äro fåtaligare. Dock blomma under denna tid Funaria hygrometica, Tayloriae serrata och splachnoides, troligen Oedipodium, Schistostega (i början), Ulotae Bruchii och crispa (äfvenledes dessa 2 mest i början), Coscinodon, Eucladium, Seligeria Donnii (i Nordlanden), Pottia Heimii, Dicranellae heteromalla, subulata, curvata ocb cerviculata, Trematodon ambiguus samt Dicranum flagellare, af hvilka de flesta äro jordmossor. $P_{a}^{\circ}$ fjällen blomma äfven Dicrana arcticum, Starkei, falcatum och fulvellum åtminstone samtidigt med denna period i låglandet, om de också rättast måste anses 
tillhöra en långt tidigare årstid, fastän deras blomning genom deras höga växtlokal blifvit framskjuten. De på gränsen mellan de föregående perioderna och denna tid blommande akrokarpiska mossorna hafva slutligen redan förut blifvit omtalade.

Fruktmognad. Endast fä äro de löfmossor, som under denna tid få mogna frukter; desto flera börja nu att visa uppstickande, unga fruktskaft eller t. o. m. fullformade frukter. Bland de pleurokarpiska mossorna fällas nu locken endast af några få på stenar och klippor växande arter, nemligen af Hypnum Halleri, Orthothecia, Pterigynandrum (i Nordlanden) samt af Plagiothecia, hvilka äro de för denua tid mest utmärkande pleurokarpiska mossorna, och bland hvilka locken nu fällas i hela Skandinavien af Pl. undulatum, silvaticum och denticulatum, samt i Sverige af Pl. piliferum (mera normalt), Mühlenbeckii och nitidulum. Angående Plagiothecia må det dock anmärkas, att det mest är mot slutet af denna tid, som de börja visa mogna frukter. Hypnum pallescens börjar äfven fälla locken mot slutet, och slutligen hör äfven det på trädrötter växande Thujidium gracile till denna tid.

Äfven bland de akrokarpiska mossorna är de nu fruktsättande arternas antal ytterst litet. De enda hithörande jordmossorna äro, utom ett par Brya, Trematodon-arterna (mest i början) och Tayloria splachnoides. Bland Brya märkas nu Brya intermedium, erythrocarpum, Zieriae, Weberae polymorpha och acuminata samt de nu för andra gången fruktsättande Brya Warneum och calophyllum. Bland sten- och klippmossorna fruktsätta nu Mielichhofferia, (Tortulae alpina och icmadophila enligt förff.) samt i Nordlanden Seligeria Donnii. Mest utmärkande för denna tid äro dock bland de akrokarpiska mossorna de sköna, på trädstammar växande Ulotae Ludwigii, Drummondii, Bruchii och crispa, samt de i skogar och på klippor allmänna Dicrana, bland hvilka sistnämnda D. montanum nu normalt fäller locken och de till den 11:te perioden normalt hörande arterna nu visa vackra, snart mogna frukter, hvilka ibland redan under denna tid, åtminstone vid pressning, kunna fälla locken. Slutligen må Sphagna, ehuru ej tillhörande löfmossorna, omnämnas såsom serdeles karakteristiska genom sina mogna frukter för så väl denna tid, som äfven, såsom redan är nämndt, för den föregående perioden.

X. Löffällningen (Mensis defoliationis L.). Börjar vid Hernösand omkring den 15 September och slutar omkring den 15 Oktober. Körsbärsträden stå dock ännu gröna vid periodens slut 
och fälla sina blad först temligen långt in i nästa period. Vid Upsala angifves löffällningen vara vanligen från de sista dagarne af September eller första dagarne af Oktober till omkring den 1 November. Ju längre vi komma mot söder, desto senare både börjar och slutar denna period, och desto större vexlingar äro dess gränser underkastade. I Skåne börjar den alltid efter början af Oktober och slutar omkring medlet af November. Körsbärsträden stå dock äfven der gröna in i nästa period, ofta ända till slutet af November. Ju längre vi komma mot norden, desto förr både börjar och slutar perioden, desto kortare blir den, och desto mindre vexlande är äfven den tid, inom hvilken dess gränser kunna variera. Perioden torde börja straxt efter den 1 September i Nordlanden vid polcirkeln. Förf. kan dock ej lemna några bestämda uppgifter om gränserna för denna och de 2 följande perioderna för något nordligare ställe, än Hernösand.

Blomning. De flesta löfmossor hafva nu fullkomligt afslutat $\sin$ blomning; det är endast några få, som undantagsvis kunna finnas med mogna blommor ännu under denna period, nemligen Plagiothecia, t. ex. Pl. Mühlenbeckii, Eucladium, enligt exemplar från Baireuth, som blommade i Oktober 1870, Pottia Heimii och stundom de 4 under förra perioden normalt blommande Dicranella-arterna.

Fruktmognad. Högst fä äro äfven de löfmossor, som nu få mogna fruktar. Bland de pleurokarpiska mossorna tillhör endast Hypnum pallescens normalt denna tid, men dessutom kunna äfven bland dem stundom de mest under den föregående perioden lockfällande Plagiothecia ännu träffas med lock. Ibland de akrokarpiska mossorna fällas nu locken af (Anomobryum), Brya intermedium, calophyllum och Warneum (af de 2 sista för andra gången under året) samt af Anoectangium. De Dicrana, som efter regeln fälla locken under nästa period, kunna äfven stundom redan nu, likasom under den föregående perioden, fälla sina lock. De jordmossor, som mest under vintern och den tidiga våren få mogna frukter, hafva dessutom nu vackra, fullformade frukter, hvilka till och med hos Pottia Starkei stundom redan under denna tid fälla locken.

XI. Prostperioden (Mensis congelationis L.) börjar vid Hernösand vid löffällningens slut omkring den 15 Oktober och slutar vanligen med första veckan af November, d̊̊ i vanliga fall redan de mindre vattensamlingarne och de inre delarne af hafsvikarne hafva blifvit belagda med is. Temperaturen är här 
ganska vexlande under denna period; marken vexelvis fryser och upptinar, och snöfall äro under denna tid ej heller ovanliga, men den fallna snön qvarligger sällan någon längre tid. Vid Upsala angifves perioden vara från den afslutade löffällningen till den sista grönskande örten och vanligen sammanfalla med November. Ibland alla perioder är denna dock den till sina gränser mest vexlande, isynnerhet ju längre vi komma mot söder. I Skåne börjar den omkring medlet af November, men slutet är ganska obestämdt, och ibland torde der denna period till och med helt och hållet inkräkta på den nästa. I de nordligare delarne af Skandinavien blifva deremot periodens gränser allt mindre vexlande och densamma äfven kortare; dock felas några närmare uppgifter om dess gränser och natur derstädes.

Blomning. Ingen löfmossa har under denna period blifvit funnen med mogna blommor.

Fruktmognad. Ingen pleurokarpisk mossa fäller nu i Skandinavien locken; de hos oss under Såningstiden lockfällande pleurokarpiska mossorna visa dock nu fullformade, unga frukter och äro derigenom för denna tid karakteristika. I mellersta Europa fällas deremot oftast locken hos dessa mossor redan under denna period, såsom redan förut är omtaladt. Ibland de akrokarpiska mossorna äro Dicrana mycket utmärkande för perioden genom sin lockfällning. De flesta arterna af detta stora slägte fälla nu locken, nemligen D. Undulata (utom D. robustum och spurium), Scoparia, Orthocarpa (utom D. strictum, viride och montanum) samt Dicranum arcticum. I likhet med Dicrana torde äfven Dicranodontium longirostre nu, fälla locken. Dessutom mogna nu frukterna hos 4 kleistokarpa mossor, nemligen hos Pleuridium nitidum, Ephemerella, Ephemerum och Physcomitrella. De under vintern lockfällande jordmossorna hafva nu äfven vackra frukter, hvilka stundom redan under denna period, åtminstone vid pressning, kunna fälla sina lock, såsom det ofta är fallet med Pogonata urnigerum och capillare, Catharineae, Brya pallens, uliginosum, Brownii?, purpurascens och arcticum, Tortulae i egentlig mening, Leptotrichum tortile $\beta$ pusillum, Pottiae Starkei och truncata samt Gymnostomum squarrosum.

XII. Snöperioden (Mensis nivalis L.) varar vid Hernösand från omkring den 10 November, då sjöar och hafsfjärdar börja isläggas, till årets slut. Snön kommer der äfven straxt efter isläggningen och qvarligger sedan, efter några få och korta strider om herraväldet, under vanliga år utan afbrott ända till slutet af 
April det följande året. Vid Upsala sammanfaller denna period vanligen med December och visar vanligen äfven qvarliggande snö. I sydligare delar af Skandinavien blir deremot perioden allt kortare, och i Skåne kan till och med ofta innan årets slut ingen qvarliggande snö hafva visat sig. Deremot ju längre mot norden vi komma, desto längre blir perioden, och desto mera utmärkes den genom oafbrutet qvarliggande is och snö. Härifrån torde dock nordliga Skandinaviens kuster göra undantag; genom det mildare hafsklimatet torde det derstädes ofta hända, att qvarliggande snö ej finnes under årets sista månader.

Blomning. Ingen löfmossa blommar under denna tid.

Fruktmognad. I sydligare delen af Skandinavien, der stundom under denna period blidväder kan inträffa och marken blifva fri från snö, kunna de vid den föregående perioden nämnda jordmossorna fälla locken äfven under denna tid. Inga nya för perioden karakteristiska jordmossor tillkomma.

I sammanhang med föregående kalendarium får förf. slutligen framhålla, dels att man från detsamma kan hemta goda hjelpmedel för den speciella bryologien, dels äfven att genom kännedomen om tiderna för blomningen och fruktsättningen man i vanliga fall lätt finner, hvilken tid frukterna behöfva för sin utveckling.

Från de ofta för olika arter olika blomnings- eller fruktmognadstiderna kunna nemligen biologiska karakterer af stort värde för den speciella mosskännedomen hemtas. Det är ej af nöden, att här närmare framhålla de serskilda fall, i hvilka sådana hjelpmedel för den speciella mosskännedomen kunna vinnas. Förf. hänvisar i detta afseende till de efterföljande specialobservationerna, emedan det vid denna framställning i systematisk följd af alla den Skandinaviska halföns löfmossor är lätt att få de upplysningar, som kunna önskas i hvarje serskildt fall.

Äfven $i$ ett annat afseende lemnar detta kalendarium hjelp åt den speciella bryologien, nemligen då det är fråga om att konstatera könsförhållandet, $\mathrm{i}$ det att uti detsamma tiderna för de serskilda arternas blomning äro angifna. Det är nemligen lättast att bestämma könsförhållandet hos mossorna vid blomningstiden, emedan blommorna då förefinnas i största mängd. $\AA$ den andra sidan är det deremot ofta omöjligt att kunna säkert bestämma detsamma på mossor, som äro insamlade utom den egent- 
liga blomningstiden, emedan blommorna stundom kunna kort efter blomningen bortfalla. Det är isynnerhet hanblommorna, som ofta äro flygtiga. Hos några löfmossor äro dock äfven honblommorna flygtiga, så att de efter den egentliga blomningstiden sällan qvarsitta någon längre tid, hvarpå exempel lemnas af de $\mathrm{i}$ kärr växande pleurokarpiska mossorna, af Pottiae, enligt Bryol. Eur., m. fl. Hos andra löfmossor qrarsitta väl blommorna och då isynnerhet honblommorna ofta länge efter blomningen, ibland till och med tills nästa blomgeneration hunnit utvecklas, så att man hos dessa kan bestämma könsförhållandet på exemplar från de mest olika årstider. Emedan blommorna alltid äro i största antal för handen vid blomningstiden, så är det dock alltid då lättast att med någon säkerhet konstatera könsförhållandet, hvarföre vid denna tid insamlade mossor i främsta rummet böra för detta ändamål begagnas.

Såsom vi här ofvan antydt, framgår det slutligen äfven utaf det föregående kalendariet $i$ de flesta fall med lätthet, hvilken tid det behöfves för frukternas utveckling till mognad ifrån blomningen eller befruktningen räknadt. Som den olika tid, som frukterna hos löfmossorna behöfva för sin utveckling, ej förut blifvit nöjaktigt utredd, torde en framställning af de väsendtligaste olikheter, som löfmossorna i detta afseende visa, vara af intresse, isynnerhet som det ej alltid är klart endast genom uppgifterna om tiderna för blomningen och fruktmognaden, huru lång denna tid kan vara.

Endast få äro de uppgifter, som förut förefinnas om denna tid. Det största antalet sådana uppgifter finna vi i en af handling af D:r H. von Klinggräff: »Zur Sexualität der Moose» ${ }^{1}$ ), hvilken äfven blifvit refererad af D:r J. Sachs ${ }^{2}$ ). Vid detta referat hafva dock ett par sjelfständiga, oriktiga slutledningar blifvit gjorda, nemligen att frukterna hos Funariae skulle använda blott $1-2$ månader och hos Phascum cuspidatum endast få veckor på fruktutvecklingen. Utom i föregående uppsats hafva äfven, såsom redan på sidan 5 af denna afhandling blifvit omtaladt, $\mathrm{i} \gg$ Bryologia Europaea» och $\mathrm{i}$ »Synopsis muscorum» i några enstaka fall den tid, som behöfves för fruktutvecklingen, blifvit mer eller mindre noggrant angifven. De redan förefintliga uppgifterna äro likväl få, och dessutom äro de ej gjorda med afseende på för-

1) I ,Botanische Zeitung, 1860, sidd. 344-345.

2) I sLehrbuch der Botanik», 4:de uppl., sir. 373. 
hållandena i vårt land, utan afse mellersta Europa, hvarföre de ibland ej öfverensstämma med våra förhållanden. Den tid, som frukten kräfver för sin utveckling, är nemligen olika lång på olika breddgrader och synes oftast blifva längre, ju längre mot norden vi komma. Orsaken till sistnämnda faktum kan vara tväggehanda. Sålunda kan det för det förstä nánda, att löfmossor, som hinna på samma vegetationstid, som frukterna blifvit anlagda, utveckla dessa till mognad fram på hösten i mellersta Europa, i Skandinavien ej hinna få mogna frukter förr än under början af nästa vegetationstid. Sådant är t. ex. förhållandet med många på 26:te sidan af denna afhandling omnämnda löfmossor. För det andra finnes det många löfmossor, som först under den efter blomningen följande vegetationstiden hinna fa mogna frukter äfven i mellersta Europa. Dessa fa mot norden en allt längre vinter, under hvilken utvecklingen går mera långsamt, inskjuten mellan blomningen och fruktmognaden, hvarföre äfven tidskilnaden mellan blomningen och fruktmognaden mot norden blir allt större.

Fästa vi oss vid de Skandinaviska förhållandena och efterse den tid, som inom Skandinavien behöfves för frukternas utveckling hos löfmossorna, så skola vi finna, att den kortaste tid, som för detta ändamål erfordras, öfverstiger 3 månader, och att den längsta uppgår till omkring 23 månader. Största delen af löfmossorna behöfver dock mindre, än ett år, för fruktens utveckling. Bland dessa användes den kortaste tiden af några fă, som kunna hinna få frukterna mogna under den vegetationstid, under hvilken de blifvit anlagda. Hos de öfriga mogna visserligen frukterna under en senare vegetationstid än den, under hvilken de blifvit anlagda, men då vanligen så tidigt under den följande vegetationstiden, att det är för kallt för blommorna att utvecklas samtidigt med fruktmognaden, hvarföre blomningen inträffar först mer eller mindre långt efter densamma. Ganska få äro deremot de löfmossor, som få mogna frukter under lifligare utvecklingsperioder af året och likväl blomma först längre tid efter fruktmognaden. Exempel härpå lemna dock de flesta i kärr växande pleurokarpiska mossor, samt Buxbaumiae och Bartramiae. Öfvergå vi till speciella fall, så finnes, så vidt förf. känner, den snabbaste fruktutrecklingen hos Pottiae truncata och Starkei samt, åtminstone i Sverige, hos Catharinea tenella, hvilka 3 blomma i medlet och slutet af Juli och stundom fälla locken redan i början af November. Fruktutrecklingen har således hos dessa med- 
hünits på föga öfver 3 månader. Fulla 4 mánader och stundom ända till 6-8 månader behöfra dock dessa mossor äfven ofta för detta ändamål. Tyvärr känner förf. ej säkert, utan kan blott från anılogi sluta till blomningstiden för de på senhösten fruktsättande kleistokarpa mossorna, Pleuridium nitidum, Physcomitrella, Éphemerella och Ephemerum. Dessa blomma dock allra sist i slutet af Juli och få mogna frukter ofta redan i början af November; de behöfva således minst 3 månader för fruktutvecklingen. Snabbaste fruktutvecklingen näst de ofvannämnde mossorna visa några jordmossor, som blomma vid midsommartiden eller straxt förut och fälla locken stundom redan i slutet af November och i December, dock oftare under Januari-Mars, och således använda ibland blott 5 månader, men oftare $6-9$ på fruktutvecklingen, såsom fallet är med Catharinea undulata, Tortulae fallax, unguiculata, recurvifolia, ambigua, stellata, aloides och brevirostris, Leptotrichum tortile $\beta$ pusillum och de flesta Dicranellae. Fissidens-arterna kunna äfven få mogna frukter i Januari-Maj, eller 5-10 månader efter blomningen, Pogonata urnigerum och capillare i December-Mars, eller 6-9 månader efter blomningen. De ofvannämnda mossorna äro alla akrokarpiska; bland de pleurokarpiska är Pylaisia snabbast och kan redan i December fälla locken efter 6 månaders fruktutveckling. Eurhynchia (utom strigosum och diversifolium) och Heterocladium dimorphum utveckla bland dem sina frukter på föga mera än 8 månader. Ibland de öfriga löfmossorna, hvilkas frukter utvecklas på mindre än ett år, vilja vi blott nämna de förnämsta. Hylocomia, Brachythecia, Anomodon-arterna m. fl. af de pleurokarpiska mossor, som fälla locken under Såningstiden, blomma sålunda från midsommar till framåt slutet af Juli månad, och vexlar således deras tid för fruktutvecklingen från $9 \frac{1}{2}-11$ månader. Schistostega och Discelium använda på densamma 10

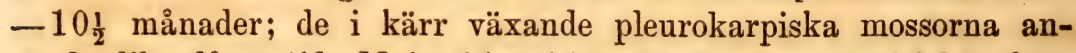
vända lika lång tid, Mnia 11-111 månader o. s. v. Af det ofvan anförda se vi äfven, att endast högst få löfmossor hinna utveckla sina frukter under samma år som det, hvarunder de anläggas.

Ett stort antal löfmossor blommar äfven samtidigt med fruktmognaden och använder således 12 månader på fruktutrecklingen. Det är dock förnämligast blott de under sommaren fruktsättande mossorna, som blomma samtidigt med fruktmognaden. Endast $f_{a}^{\circ}$ af de före Löfsprickningen fruktsättande arterna blomma deremot liktidigt med densamma; exempel härpå lemna dock. 
Isothecia, Homalia, en del Grimmiae samt Andraeae. Till och med de löfmossor, som få mogna frukter under Löfsprickningen, blomma sällan förr, än litet efter fruktmognaden, hvarpå Mnia och de då lockfällande Weberae lemna exempel. Det största antalet af de mossor, som fruktsätta under sommaren, blomma deremot, såsom det redan blifvit sagdt, samtidigt dermed och använda således omkring 12 månader på fruktens utveckling; vi hafva dock redan sett, att äfven hos en del af dessa blomningen inträffar först en längre tid efter fruktmognaden, och i det följande skola vi se, att äfven några af dessa löfmossor blomma straxt före densamma. Ibland de löfmossor, som blomma samtidigt med fruktmognaden och använda omkring 12 månader på fruktutvecklingen må anföras Drepania, de flesta Amblystegia, Plagiothecia, Eurhynchia strigosum och diversifolium, Fontinales, de flesta Brya, af hvilka dock Bryum argenteum troligen använder blott 10 månader och Brya pallens, uliginosum m. fl. 17-22 månader på fruktens utveckling, Splachnaceae, Orthotricha, Seligeriae, några få Dicrana, t. ex. D. robustum och Blyttii m. ff.

Jemförelsevis få äro deremot de mossor, som för fruktutvecklingen behöfva mera än ett år, och har detta förhållande, förf. veterligen, endast för en mossa, nemligen för Hypnum cupressiforme, blifvit förut anmärkt. H. cupressiforme, som i Preussen, enligt Klinggräff, blommar på hösten och först vid slutet af vintern, nära $1 \frac{1}{2}$ år derefter, får mogna frukter, blommar dock hos oss på våren straxt efter fruktmognaden och använder således i Skandinavien litet mindre än ett år på fruktens utveckling. De löfmossor, som i Skandinavien använda mera än ett år på fruktutvecklingen, fälla mest locken mer eller mindre långt efter midsommar och blomma förr, än de fälla locken. Hos ganska många mossor kan blomningen infalla en kortare tid före lockfällningen, såsom t. ex. hos Cinclidia, hvilka blomma minst 1 till 2 veckor före lockfällningen. Likaså blommar Tortula muralis minst 2 veckor och Didymodon rubellus nära en månad före fruktmognaden. Fruktutvecklingen kräfver således hos dessa löfmossor $12 \frac{1}{2}$ till nära 13 månader. Omkring en månad eller litet mera före fruktmognaden blomma följande, som sålunda behöfva 13 månader eller litet mera för fruktens utveckling, nemligen Tetraphis, de flesta Polytricha, Timmiae, Conostomum, Gymnocybae, Aulacomnium, Weberae cruda, longicollis, elongata, polymorpha och 
acuminata, de flesta Encalyptae, Leptotrichum flexicaule samt Dicranum montanum.

I fråga om dem, som behöfva ännu längre tid för fruktutvecklingen, torde en mera detaljerad framställning kunna vara af intresse. Zieriae och Mielichhofferia blomma sålunda i början af Juli och få frukterna mogna först i slutet af Augusti nästa år, således omkring 14 månader efter blomningen. - Anomobryum julaceum behöfver minst lika lång tid; denna mossa blommar nemligen $i$ slutet af Juli och sätter enligt exemplar från Tyrolen ej mogna frukter förr, än i Oktober nästa år. - Ulotae Drummondii och Ludwigii blomma i Norge före midsommar och få frukterna mogna nästa år i slutet af Augusti och i September, således efter 14-15 månader. - Ibland Dicrana fordra de olika arterna en olika lång tid för fruktens utveckling. Endast några få Dicrana, såsom D. robustum, spurium, Falcata och Fulvella, blomma och fälla locken samtidigt. Ibland de öfriga blomma de

flesta från midten af Juli till de första dagarne af Augusti, men locken fällas nästa år först senare, af D. montanum först i slutet af Augusti, af de öfriga endast undantagsvis före Oktober månad, ofta äfven först i December. Sålunda behöfva Dicrana från 12 ända till 17 månader för fruktutvecklingen. P̊ Skandinaviens vestkust, åtminstone $\mathrm{i}$ Nordlanden, synes blomningen inträffa redan i Juni månads början hos en del Dicrana. Tiden för fruktmognaden torde dock äfven derstädes infalla något tidigare, än i Sverige, så att den tid, som frukterna använda på sin utveckling, ej i nordliga Norge blir mycket längre, än i Sverige. - Hypnum Crista castrensis och troligen äfven Hypnum purum äro de enda pleurokarpiska mossor, som taga $\mathrm{i}$ anspråk en tid, som betydligt öfverstiger 1 år, för fruktutvecklingen; den förra behöfver derför, och likt denna troligen äfven den senare, minst 16 månader och ibland ända till 21 . H. Crista castrensis blommar nemligen i början och midten af Augusti, och frukterna mogna i södra Sverige sällan före December nästa år; stundom sitta der locken qvar ännu i Januari eller senare. I mellersta och nordliga Skandinavien täcker snön under vintern marken, och fällas derför locken derstädes ej förr än omkring den 1 Maj eller senare, således först omkring 21 månader efter anläggningen. - De 4 Dicranellae heteromolla, subulata, curvata och cerviculata visa en egendomlig olikhet med slägtets öfriga arter deruti, att hos dessa 4 arter fruktutvecklingen varar 16-19 månader, under det den hos slägtets öfriga arter varar 
endast 6-8 månader. Dessa 4 arter blomma nemligen omkring den 1 September och först i December nästa år eller oftast äfven 2-3 månader senare fällas locken. - Ännu större olikhet visa Leptotricha homomallum och pallidum från den närstående Leptotrichum tortile $\beta$ pusillum; de 2 första behöfva nemligen 22 till 23 månader för fruktutvecklingen, det sista deremot $5-8$. De förra blomma nemligen i Augusti, men först i April-Juni, nära 2 år derefter mogna frukterna. - Bland Brya äro Br. pallens, uliginosum, purpurascens, areticum och troligen likt dessa äfven Brownii utmärkta för sin långa tid för fruktutvecklingen (1722 månader). De blomma i början af Juli, och först i November eller December nästa år börjar lockfällningen, hvilken i nordligare delar af Skandinavien till och med framskjutes till snösmältningens slut i Maj, nära 2 år efter blomningen. - Den längsta fruktutrecklingen, eller under en tid af öfver 22-23 månader, visar dock Grimmia Donnii, hvilken blommar före slutet af Juni och på senhösten nästa år visar vackra, fullformade frukter, hvilkas lock likväl ej fällas förrän straxt före Löfsprickningen, nära 24 månader efter befruktningen. Likt den föregående förhålla sig G. ovata, åtminstone alltid i Nordlanden och ofta äfven i sydligare trakter, samt troligen äfven Coscinodon.

Den långsamhet $\mathrm{i}$ utvecklingen, som frukterna hos löfmossorna oftast visa, afsticker bjert mot den raska utveckling, som hos största delen af de öfriga växterna förefinnes. Bland fanerogamerna hinna t. ex. kornet och rågen att på mycket kortare tid än ett år, ofta på blott ett par månader, utveckla sig till flera alnars höjd. Hvarje individ hinner under denna korta tid utveckla axel- och bladorganer, blommor och mogna frukter med den ändlösa differentieringen af cellväfnaderna för att motsvara olika fysiologiska ändamål. Den lilla mossfrukten, som i fråga om storlek, cellernas antal och differentieringen af cellväfnaden kanske ej öfverträffar en enda ståndare hos fanerogamerna, kan deremot behöfva en mångdubbelt längre tid, än ett helt fanerogamindivid, för sin utveckling. Ännu skarpare framträda skiljaktigheterna i fråga om utvecklingens hastighet, om vi tänka på det fruktifikativa systemet hos de större svamparne, hvilket stundom ej behöfver mera än ett dygn för utvecklingen af sin stora massa. Svamparne och löfmossorna kunna derföre väl uppställas såsom exempel på ytterligheterna $\mathrm{i}$ fråga om hastigheten af vegetativ utreckling. 


\section{De till grund för det föregående blomningskalendariet lig- gande observationerna på löfmossornas blommor.}

I det följande lemnas slutligen en redogörelse för de af af förf. gjorda observationerna på löfmossornas blommor. På dessa observationer har i främsta rummet det kalendarium för löfmossornas blomning, som i det föregående framstälts, blifvit grundadt. De meddelas här nedan, på det att det från dem må framgå, till hvilken grad af tillförlitlighet $i$ resultaterna förf. i hvarje serskildt fall kan hafva kommit, samt äfven på det att det må synas, i hvilka fall noggrannare undersökningar kunna behöfvas, än de, som förf. haft tillfälle att göra. Ett annat skäl, hvarföre observationerna äro här meddelade, är det, att desamma, hvilka måste göras med mikroskopets tillhjelp, ofta äro förenade med ganska mycket arbete och med stor tidspillan, hvarföre sådana observationer, sedan de en gång blifvit gjorda, torde böra tillvaratagas.

För att större värde måtte gifvas ăt denna redogörelse, hafva äfven vid de serskilda arterna tiderna för deras blomning och fruktmognad blifvit angifna. Dessutom hafva i anmärkningar under de serskilda arterna de iakttagelser, förnämligast i morfologiskt hänseende, som förf. dessutom gjort vid sina undersökningar af blommorna, blifvit omnämnda. Serskildt hafva könsorganerna ofta blifvit räknade och deras antal i hvarje serskild blomma blifvit angifvet. Af dessa siffror framgår det lätt, att 4-talet sträfvar att göra sig gällande äfven i mossornas blommor, likasom samma tal, såsom sedan gammalt är bekant, mera konstant herrskar hos frukterna, hvilket visar sig uti antalet af peristomets tänder m. m. Könsorganernas normala antal är nemligen 4, 8, 12, 16 eller 32; dock träffas äfven ibland 6,10 eller 14 könsorganer i blommorna, men deremot är deras antal endast sällan udda.

I det följande har den af Lektor Hartman i sista upplagan af "Skandinaviens Flora" använda uppställningen af löfmossorna blifvit följd och hafva äfven i samma system inordnats de nya medborgare af Skandinaviska halföns flora, som blifvit funna, sedan denna sista upplaga utgafs.

För utrymmets besparande har förf. sökt fatta sig så kort, som möjligt, samt äfven användt en del förkortningar, hvilka det dock torde vara lätt att förstå. Förkortningarne af lokalnamnen äro gjorda i likhet med de i "Skandinaviens Flora" begagnade och torde derför vara bekanta för hvarje svensk läsare. I fråga om tidsuppgifterna hafva vid årets angifvande de 2 första siffrorna blifvit utelemnade, emedan alla iakttagelserna äro gjorda på exemplar från de sista åren eller åtminstone på exemplar från 1800-talet. Vid uppgifterna om månader och data har förf. deremot af typografiska skäl fått öfvergifva det förut begagnade beteckningssättet $\mathrm{i}$ bråkform. Vid angifvandet af tiderna för blomning (Bl.) och fruktmognad ( Fr.) hafva periodernas ordningsnumror, I, II, III o. s. v., blifvit använda, hvarvid dessa numror blifvit satta inom klammer, då blomning och fruktmognad infalla endast mera abnormt på de genom dessa numror angifna tiderna. De öfriga förkortningarne torde vara lätta att förstå; i fråga om dem hänvisas dock till den första arten, Hylocomium splendens, emedan vid denna art de flesta af de sedan förkortade termerna äro fullt utskrifna. 


\section{Musci pleurocarpi.}

\section{Ordn. Hypnaceae.}

Hylocomium splendens Br. \& Sch. Blomning: under VI:te perioden. Fruktmognad: under den IV:de. Hanblommor: unga slutna antheridier VG. 2 Juni 73 och Ångml. Juni 73; antheridier mogna med svärmande antherozoider Ångml. 7 Juli 74; öfvermogna, tömda antheridier Sk. 5 Juli 69, ÖG. 4 Aug. 70 och Lapponia orientalis Aug. 72. Honblommor: fjolårsblommor med vissnade arkegonier och ett befruktadt felslaget, som knappt höjde sig ofvan perichetiet VG. 2 Juni 73; blott fjolårsblommor med vissnade, men stundom dock slutna arkegonier Ångml. Juni 73, Sk. 5 Juli 69 och Ångml. 3 Juli 74; ett par blommor dels med fullformade, slutna arkegonier eller till och med ett öppnadt, dels med ej fullt utvecklade arkegonier och ibland till och med antheridlika, unga sådana Ångml. 15 Juli 74 .

Anm. Antheridiernas antal 5-7, arkegoniernas 8 eller 12 .

H. umbratum Br. \& Sch. $B l$.: i slutet af den V:te perioden och början af den VI:te. Fr.: III. Hanbl.: unga, slutna anth:r Sköfde 2 Juni 73, Ångml. Juni 73 och 4 Juli 72 samt Nordl. 31 Juli 70; åtminstone några anth:r öppna Ångml. 7-17 Juli 74. Honbl.: slutna, fullformade ark:r Ångml. 4 Juli 72; öfvermogna, något vissnade ark:r Ångml. 8 Juli 73; ett par ark:r öppna, de öfriga slutna Ångml. 17 Juli 74 .

Anm. Hanparafyserna blifva vid hanbl:s mognad gula. Ark:ernas antal normalt 12 .

H. Oakesii Sch. $B l .:$ V i slutet och VI i början. Fr.: III. Hanbl.: unga, slutna anth:r Ångml. 1 Juni 70, Juni 73 och 11 Juli 74 . Honbl.: en blomma just mogen, några ark:r ofärgade och slutna, andra med halsen och öfre delen af buken färgade Dovre Juni 57 (rätt tid?); blott fjolårsblr med vissnade ark:r Ångml. 4 Juli 72; halfvuxna fruktskaft Ångml. 17 Sept. 74.

Anm. Hanparafyserna äro vid blommornas mognad gula; anth:ernas antal är normalt 12 .

H. brevirostre Br. \& Sch. Bl.: (slut V) och början VI. Fr.: III. Hanbl.: slutna, snart mogna anth:r Sk. 20 Juni 71. Honbl.: gammal fjolårets Sk. 25 Maj 72; vissnade ark:r, men tydligen tillhörande en årets blomma Bergens st. Juli 73.

H. loreum Br. \& Sch. Bl.: V. Fr.: III. Hanbl.: unga, slutna anth:r VG. 5 Juni 73 och Lysekil Juni 70 ; just mogna, några anth:r öppna, de andra slutna ÖG. Juli 69 ; öfvermogna, tomma och bruna anth:r OG. Aug. 71. Honbl.: just mogna, ark:r dels ofärgade och slutna, dels öppna med halsen och öfre delen af buken bruna VG. 5 Juni 73 och 
Molde 28 Juni 72; öfvermogna, ett ark. befruktadt, de öfriga med friska, ofärgade fôtter, för öfrigt vissnade och bruna Sk. 5 Juli 69 och ÖG. Juli 69.

Hylocomium triquetrum Br. \& Sch. $B l .:$ V i slutet och VI i början. Fr.: III. Hanbl.: anth:r ofärgade, unga och slutna, ett par dock gulaktiga, men slutna Ner. 10 April 73; unga, slutna Ångml. 14 Juni 70; ej gamla anth:r, några synas t. 0. m. ännu vara slutna ÖG. 4 Aug. 70. Honbl.: ung med tydliga, fullformade ark:r Ner. 10 April 73 (utvecklad på abnorm tid!); fjolårsblomma med vissnade ark:r och ett hämmadt, befruktadt Ångml. 14 Juni 70; flera fjolårets honblr med vissnade, men dock ibland slutna ark:r, derofvan unga honbl. med blott parafyserna utvecklade Ångml. 3 Juli 74; unga, sällan fullformade ark:r Ångml. 11 Juli 74; ett befruktadt friskt ark. med buken ännu ofärgad ÖG. 4 Aug. 70.

Anm. Ark:r normalt 16 till antalet. $\mathrm{P}_{\mathrm{a}}^{\circ}$ ett exemplar fans en samkönad blomma!

H. subpinnatum Lindb. $B l$.: i analogi med den följande i VII:de perioden. Fr.: III. Hanbl.: gamla med bortfallna anth:r Gefle Okt. 73. Honbl.: gamla blommor med vissnade ark:r, hvilka likväl stundom voro ofärgade, Ner. Maj 70, Hernösand 3 Juni 70 och 0kt. 73 samt Gefie 0kt. 70 .

Anm. Arkegoniernas antal 12-18.

H. squarrosum Br. \& Sch. Bl.: VII. Fr.: III. Hanbl.: mycket unga, knappt urskiljbara anth:r Ner. 6 April 73; just mogen, anth:r grönaktiga, slutna eller bruna, tömda Sk. Juli 68; temligen unga blr, dock stundom ett och annat anth. öppet med svärmande antherozoider Ångml. 11-25 Juli 74. Honbl.: mycket unga, knappt igenkänliga ark:r Ner. 6 April (på abnorm tid utvecklad blomma!); fjolårsblommor med vissnade ark:r och ett felslaget, befruktadt Sk. Juli 68; blommor ännu unga med blott parafyserna utvecklade Ångml. 7 och 16 Juni samt 7 och 16 Juli 74; blott en del ark:r fullformade och slutna, de öfriga ännu unga och antheridlika Ångml. 3 Aug. 74.

Anm. Könsorganernas antal $6-8-12$. Uti unga honblommor äro parafyserna hos denna löfmossa, likasom hos de fleste andra, tidigast utvecklade och synliga förr, än det ännu synes något spår af arkegonierna. Hos Paludella och Hedwigia skall enligt, Bryologia Europaeas förhållandet vara motsatt, i det att vid blomningen inga parafyser $\mathrm{i}$ honblommorna förefinnas, utan utvecklas dessa först efter densamma eller under fruktutvecklingen.

I. Halleri Sw. $B l$.: VIII och IX i Nordl. Fr.: VIII och IX. Hanbl.: somliga blommor med slutna unga anth:r, andra med öppna och tömda Nordl. 27 Juli 70; slutna, ej än mogna anth:r Nordl. 30 Aug. 70. Honbl.: vissnade ark:r, dock fötterna ganska friska Nordl. 27 Juli 70; ark:r dels slutna och ofärgade, dels öppna med brun hals Nordl. 30 Aug. 70; fötterna ännu friska på de för öfrigt vissnado ark:rna Nordl. 2 Sept. 74.

Anm. Ark:r omkring 6 till antalet.

H. Sommerfeltii Myr. Bl.: slut V och början VI. Fr.: V. Hanbl.: ännu ofärgade, slutna anth:r Södml. 10 Juli 68 och Uppl. Juli 72; i flera 
blommor anth:rna snart mogna och slutna eller öfvermogna och nyss tômda Braunschweig Juli 73. Honbl.: en blomma med ett nyss befruktadt, ännu ofärgadt ark. Södml. 10 Juli 69; snart mogna, ett par ark:r ôppna Uppl. Juli 72.

Anm. Anth:rnas antal 4-5 i hvarje blomma.

Hypnum stellatum Schreb. Bl.: (slut V) - IX. Det är mest i södra Sverige, som blomningen kan inträffa så sent, som under IX:de perioden. Fr.: V i slutet och VI. Hanbl.: små, otydliga (han- eller honblr.?) Ångml. 1 Juni 70; just mogna, ark:r slutna, ofärgade eller öppna med brunfärgad hals Trondhjem 27 Juni 70 och Ångml. 4 Juli 74, Salten i Nordl. 21 Juli 69, Angml. 3 Aug. 73 och ÖG. omkring den 1 Sept. 71; mycket unga, knappt urskiljbara ark:r Ranen i Nordl. 19 Juli 70; vissnade ark:r med endast fötterna friska och ofärgade Hall. 29 Aug. 68.

Anm. Hanparafyser i mogna blommor gulaktiga.

H. chrysophyllum Brid. Bl.: (VII) VIII och IX i analogi med andra i kärr växande pleurokarpiska mossor. Fr.: V i slutet och VI. Honbl.: gammal fjolårsblomma med vissnade ark:r Stockh. Juli 69.

Anm. 18 ark:r räknades $i$ en blomma.

H. elodes Spruce. Bl.: (VII) VIII och IX i analogi med andra i kärr växande pleurokarpiska mossor. Fr.: V i slutet och VI likt föreg. Hanbl.: unga, ofärgade, slutna anth:r Öl. 2 Juli 67.

H. polygamum Wils. Bl.: VII (-VIII och IX i södra Sverige); Fr.: VI. Blommor: i samkönad blomma både anth:r och ark:r fullformade, men slutna Ångml. Juli 72 och Upsala Juni 70; hanblr och samkỏnado blr ganska unga, dock ett par ark:r öppna Mdpd 21 Juli 74 och Ångml. 25 Juli 73; samkönade blr med slutna eller öppna anth:r samt med öppna ark:r med halsen och öfre delen af buken färgade ÖG. omkring 1 Sept. 71.

H. cordifolium H. $B l$.: VII i mellersta och norra Skandinavien; VIII och IX troligen likt de offriga sump-Hypna i sydliga Skandinavien. Fr.: V i slutet. Hanbl.: unga med ofärgadt grönaktiga, slutna anth:r Ångml. 14 Juni 70, ŌG. 20 Juni 68, Ångml. 5 Juli 72, Ångml. 25 Juli 73 och Lappon. orient. Aug. 72; just mogen, flesta anth:r öppna Ångml. Aug. 72. Honbl.: redan öppnade ark:r med färgad hals Ångml. 25 Juli 73; ungt fullformadt ark. i en samkönad blomma Lappon. orient. Aug. 72; öfvermogna, vissnade ark:r med fötterna och nedre delarne af buken friska Ångml. 2 Sept. 74.

Anm. Anth:rnas antal 8 normalt, ibland ända till 14. På exemplaren från Ảngml. 25 Juli 73 och från Lapp. or. Aug. 72 funnos utom enkönade blr äfven samkönade!

H. giganteum Sch. Bl.: VII i mellersta och norra Skandinavien, VIII och IX i södra. Fr.: under senare hälften af V:te perioden. Hanbl.: slutna och vanligen ofärgade, unga anth:r, några voro dock förkrympta och bruna Nordl. 27 Juli 70; årets blommor med slutna anth:r ÖG. 3 Sept. 70; mogna, öppna eller slutna anth:r ÖG. 16 Aug. 67. Honbl.: fjolårs, vissnad Uppl. Maj 70; just mogna eller något öfvermogna ark:r, àtminstone fötterna friska och ofärgade ÖG. omkring 1 Sept. 71; öfvermogna ark:r, ett par dock ännu med friska bukar Ångml. 2 Sept. 74. 
Hypnum sarmentosum WG. $B l$. : VIII och IX. $F r .:$ V i slutet och VI. Hanbl.: snart mogna anth:r Nordl. på någon höjd öfver hafvet 26 Juli 69. Honbl.: fjolårsblr med vissnade ark:r Nordl. 11 Juli 70; dels gamla fjolårsblr, dels årets med fullformade, snart mogna ark:r Ångml. 19 Aug. 74.

H. curvicaule Jur. Ej sedd af förf., men blommar troligen och får mogna frukter liktidigt med öfriga sump-Hypna, t. ex. H. cordifolium.

H. purum L. Bl.: på gränsen mellan VII och VIII. Fr.: I, II (III?), synes vara liktidig med $\mathrm{H}$. Crista castrensis. Hanbl.: fjolårets blr med gamla, bruna anth:r, dock fans stundom något litet innehåll $\mathrm{i}$ dem qvar VG. 4 Juni 73 ; blr på hufvudaxlarne just mogna med fulla, ofärgade eller tomma, bruna anth:r, i biaxlarnes blr alla anth:r ofärgade och slutna Smål. Aug. 70. Honbl.: just mogna, alla ark:r öppna med färgad hals Stavanger Juli(?) 73; ark:r dels öppna, dels slutna ÖG.omkring 1 Sept. 71.

Anm. HanbIommorna på hufvudaxlarne synas mogna tidigare, än hanblommorna på biaxlarne. En dimorfi visar det sig äfven finnas hos hanblommorna, så att de, som utvecklas från hufvudaxlarne, hafva talrikare anth:r, än de, som utvecklas från biaxlarne. En liknande dimorfi har i „Bryologia Europaea blifvit anmärkt vid Eurhynchium Stokesii, samt af förf. hos Hylocomium splendens och Hypnum Schreberi. Arkegoniernas antal är vanligast 8.

H. Schreberi Willd. Bl.: V i slutet och VI (VII). Fr.: III. Hanbl.: unga, slutna anth:r Ner. 6 April 73 och Stockh. Maj 68; alla anth:r öfvermogna, tömda och bruna ÖG. 2 Juli 70 och Smål. Sept. 70. Honbl.: unga, knappt igenkänliga ark:r Ner. 6 April 73; unga, ofärgade och slutna ark:r Angml. Juni 70 och 73 ; just mogna med öppna, färgade halsar ÖG. 2 Juli 70 och Angml. 8 Juli 74; ark:r dels ofärgade, slutna och friska, dels färgade, öppna och något vissnade Lappon. orient. Aug. 72.

H. cuspidatum L. Bl.: VII troligen i mellersta och norra Skandinavien, likasom öfriga sump-Hypna, VIII och IX i södra. Fr.: V i slutet. Hanbl.: fjolårsblomma med tömda anth:r ÖG. 1 Juli 68; snart mogna, slutna anth:r Ångml. 24 Juli 73. Honbl.: snart mogna med några öppna ark:r ÖG. 1 Sept. 71.

H. pseudostramineum C. Müll. Bl.: liktidigt med den föreg., likt andra sump-Hypna. Fr.: $\mathrm{V}$ i slutet.

H. stramineum Dicks. Bl.: VII (VIII). Fr.: V i slutet och VI. Hanbl.: ej ännu mogna, slutna anth:r Nordl. 19 Juli 70, Ångml. 3 Aug. 73 och 4 Aug. 68; just mogna öppna eller slutna anth:r Nordl. 6 Aug. 70 och ÖG. omkring 1 Sept. 71. Honbl.: just mogna Ångml. 3 Aug. 73; öfvermogna,ark:r med åtminstone fötterna friska Nordl. 6 Aug. 70 och ÖG. omkring 1 Sept. 71.

H. trifarium W. M. Bl.: troligen liktidigt med de flesta öfriga sump Hypna, VII i norra och mellersta Skandinavien, VIII och IX i södra. Fr.: V i slutet och VI.

H. turgescens Sch. Blr ej sedda af förf.. Frukt okänd.

H. molle Dicks. Bl.: VI. Fr.: V. Hanbl.: unga, slutna anth:r Lul. Lpm. 27 Juli 67 och Finm. 28 Juli 68 . Den höjd öfver, hvarpå dessa 2 exemplar blifvit tagna, är dock förf. obekant. Honbl.: öfver- 
mogna, de befruktade ark:rna med hvitgrön buk Ångml. 19 Aug. 74; linielånga fruktskaft uppsticka Ångml. 26 Aug. 74 .

Hypnum eugyrium Sch. $B l$.: VI i analogi med den föregående. Fr.: $V$ ex analogia och enligt förff.

H. norvegicum Br. \& Sch. Bl.: VI i analogi med H. molle. Fr.: $\mathrm{V}$ ex analogia och enligt förff.

H. arcticum Somf. Bl.: (VI?) VII. Fr.: V. Hanbl.: just mogna, öppna anth:r, ej alla tömda Nordl. 3 Aug. 70; öfvermogna och tömda anth:r Nordl. 20 Aug. 70. Honbl.: just mogna blommor, några ark:r ofärgade, slutna, de andra öppna med brunfärgade halsar Nordl. 3 Aug. 70; öfvermogna ark:r, endast fötterna friska Nordl. 16 Aug. 70; helt och hållet vissnade ark:r Nordl. 20 Aug. 70.

H. alpestre Sw. $B l .:$ VI i analogi med H. molle. Fr.: V.

H. palustre Huds. Bl.: (V i slutet), VI (VII). Fr.: V. Hanbl.: slutna, unga anth:r Bodö 5 Juli 69, Södml. 10 Juli 68 och Ångml. 27 Juli 72; just mogna och öppna anth:r Nordl. 22 Aug. 70 . Honbl.: öfvermogna ark:r Södml. 10 Juli 68 ; just mogna blommor med slutna, ofärgade ark:r eller öppna med färgad hals Ångml. 27 Juli 72 och Nordl. 22 Aug. 70.

Anm. Blomningen synes hafva blifvit ovanligt mycket försenad på exemplaren från Ångml. och från Nordl.

H. montanum Wils. Ej sedd af förf., men blommar troligen och får mogna frukter liktidigt med $\mathrm{H}$. molle, likt de öfriga Limnnbia.

H. ochraceum Wils. $B l$ : VI i analogi med H. molle. Fr.: V och VI, dock frukt ej funnen på den Skandinaviska halfön.

H. polare Lindb. Bl.: VI i analogi med H. molle. Frukt okänd.

H. Crista castrensis L. Bl.: på gränsen mellan VII och VIII perioderna. Fr.: (XII), I och II. Frukten behöfver öfver 16 månader för sin utreckling. Hanbl.: unga, slutna anth:r Ner. 6 April 73 och Uppl. Maj 68; just mogen blomma, en del anth:r t. 0. m. tömda ÖG. 19 Aug. 70; de flesta anth:rna öfvermogna och tömda Lappon. orient. Aug. 72. Honbl.: fjolårsblomma med ett befruktadt, felslaget ark. Uppl. Maj 68; utom öfvermogna frukter utan lock funnos talrika halftumslảnga unga fruktskaft Angml. 25 Maj 74; få ark:r fullformade, de flesta ännu antheridlika Ångml. 11 Juli 74; fullformade ark:r, ibland t. 0. m. oppna Ångml. Aug. 72 och 19 Aug. 74: öfvermogen blomma med ett befruktadt ark., som var hvitgrönt, de öfriga ark:rna med fötterna och nedre delarne af buken friska ÖG. 19 Aug. 70; temligen gamla årsark:r VG. Aug. 65 ; utom snart mogna frukter uppstucko linielånga fruktskaft Ångml. 15 Okt. 74 .

H. molluscum H. $B l$.: på gränsen mellan V och VI perioderna. Fr.: III. Hanbl.: unga, slutna anth:r VG. 8 Juni 73 ; just mogna blommor, de flesta anth:rna ofärgade, ej tömda, några bruna, men dock ej öppnade N. Hardanger Juli 73. Honbl.: vissnade, gamla ark:r VG. 8 Juni 73, Nordl. 19 Juli 70 och 15 Aug. 70 samt ÖG. 10 Juli 69; ark:r slutna, ofärgade eller öppna med brun hals Boh. Juli 69; öfvermogna ark:r med halsarne och öfre delarne af bukarne bruna och viss- 
nade Nordl. 2 Juli 70; befruktadt ark. hojande sig ofvan perichetiet Hardanger Juli 73.

Anm. Könsorganernas antal 12 eller 14.

Hypnum commutatum H. Bl.: VI-(VIII i södra Sverige). Fr.: V. Hanbl.: unga, slutna anth:r ÖG. Juli 69, Gotl. Juli 69 och ÖG. omkring 1 Sept. 71. Honbl.: en blomma från förra året med ett felslaget, linielångt, befruktadt ark., i årsblrna voro ark:rna just mogna med öppna bruna halsar ÖG. Juli 69 och omkring 1 Sept. 71; öfvermogna ark:r med friska fötter Nordl. 14 Aug. 70 och ÖG. 21 Aug. 72.

Anm. Ark:rnas antal $14 \mathrm{i}$ en blomma. Könsorganerna af båda könen äro mycket spensligare hos denna art, än hos de föregående.

H. sulcatum Sch. $B l$. och $F r$. ex analogia liktidiga med föregåendes. Honbl.: vissnade, fjolårs (?) ark:r Nordl. 6 Aug. 70.

H. rugosum L. Bl.: början af VIII. Fr.: III troligen, enligt exemplar, ej enligt förff. Honbl.: vissnade, gamla ark:r Lappon. orient. Aug. 72; just mogna blr med slutna eller öppna ark:r N. Gudbrandsdalen 18 Aug. 68.

Anm. Ark:rnas antal $12 \mathrm{i}$ hvar blomma. Blrna synas affalla mycket snart efter blomningen, så att det är nästan omöjligt att finna sådana på exemplar, som äro insamiade utom den egentliga blomningstiden. Detta förhållande har äfven förut blifvit anmärkt af C. Müller, hvaremot förff. af "Bryologia Europaea» förneka, att blommorna hos denna art äro flygtiga.

H. uncinatum H. Bl.: slut V-IX. Fr.: V-början VIII. Hanbl.: årets blr med slutna, ofärgade anth:r Ångwl. 1 Juni 70, Trondhjem 26 Juni 70 och Nordl. 31 Juli 70 ; just mogna hanblr ÖG. 4 Aug. 70. Honbl.: just mogna blr med dels slutna och ofärgade ark:r, dels öppnade med brun hals Trondhjem 26 Juni 70, Nordl. 17 och 29 Juli 69, ÖG. 4 Aug. 70 och Nordl. 2 Sept. 70.

II. fluitans L. Bl.: troligen VII i norra och mellersta Skandinavien, VIII och IX i södra. Fr.: i senare hälften af V:te perioden. Hanbl.: unga, slutna anth:r Ångml. Juni 68, Uppl. 20 Juli 67, ÖG. 13 Juli 70; åtminstone några anth:r öppna Nordl. 8 Aug. 70; anth:r ej fullt tömda Lappon. orient. Aug. 72. Honbl.: inga friska honblr hafva observerats hos denua art.

Anm. Af ofvanstående iakttagelser visar det sig, huru vigtigt det är att insamla sump-Hypna under blomningstiden, för att man skall kunna med säkerhet bestämma könsförhållandet hos dem. Hanblrna finnas visserligen utvecklade och tydliga hela sommaren, men honblrna blifva tydliga först framemot blomningstiden, hvarföre de monoika arterna bland dessa mossor, så länge endast hanblrna äro tydliga, lätt kunna misstagas för att vara dioika. Det är vanligen endast vid blomningstiden, som dessa mossor tydligen visa han- och honblr på samma individ.

I. exannulatum Gümb. Bl.: VII i norra och mellersta Skandinavien, VIII och IX i södra. Fr.: V i slutet. Hanbl.: unga, slutna anth:r Nordl. Juli 70 och Ångml. 8 Juli 73. Honbl.: ända till $\frac{1}{2}$ tum långa, uppstickande fruktskaft Ångml. 2 Sept. 74. 
Hypnum lycopodioides Schwægr. $B l$.: liktidigt med H. fluitans i analogi med öfriga sump-Hypna. Fr.: V i slutet och VI.

H. Fineiffii Sch. Bl.: VIII och IX i södra Sverige. Fr.: V i slutet och VI enligt förff. Hanbl.: mycket unga Ryssland Juni 72. Honbl.: just mogna, ark:r slutna eller öppna Sk. 2 Sept. 71; öfvermogna, vissnade ark:r med endast fötterna friska Södml. 20 Nov. 70.

Anm. Ark:rnas antal 4 eller 8.

H. Sendtneri Sch. $B l .:$ (VII) VIII och IX i analogi med öfriga sump-Hypna. Fr.: V i slutet och VI ex analogia och enligt förff.

H. intermedium Lindb. Bl.: VIII och IX i södra Sverige. Fr.: V i slutet och VI. Hanbl.: ej mogna, slutna och nästan ofärgade anth:r Upsala Juli 71, Uppl. 10 Juli 67 och Ångml. Aug. 73; tömda, gula anth:r Motala omkring 1 Sept. 71. Honbl.: mycket ung, blott parafyser utvecklade Ångml. 8 Juli 72; just mogen med några öppna ark:r ÖG. 26 Aug. 73; öfvermogna ark:r med fötterna och nedre delarne af buken friska ÖG. omkring 1 Sept. 71.

H. vernicosum Lindb. Bl.: VIII. Fr.: V i slutet i analogi med andra sump-Hypna och enl. förff. Honbl.: vackra, just mogna med några eller alla ark:r öppna Uppl. 16 Aug. 67 och ÖG. omkring 1 Sept. 71. Anm. Könsorganernas antal normalt 8 i hvarje blomma.

H. revolvens Sw. Bl.: VII, (VIII). Fr.: V i slutet. Hanbl.: ej mogna, slutna anth:r ÖG. 20 Juli 68 ; just mogna blr med åtminstone några öppna anth:r Ångml. 8 Aug. 74 och 2 Sept. 74 . Honbl.: något öfvermogna Ångml. 8 Aug. 74, Lappon. orient. Aug. 72; öfvermogna, ett befruktadt ark. stort, gulgrönt, de obefruktade med blott fötterna friska N. Gudbrandsdalen 18 Aug. 68.

H. badium Hn. Bl.: (VII) VIII och IX. Fr.: V i slutet (VI). Hanbl.: årets blommor med unga, slutna anth:r Nordl. 17 Aug. 70 och Ångml. i medlet af Aug. 72; anth:rna höllo på att tömmas Ångml. i slutet af Aug. 72. Honbl.: snart mogna blr med slutna, ofärgade ark:r Nordl. 29 Juli 70 ; just mogna, åtminstone några ark:r öppna med brun hals Angml. i slutet af Aug. 72 och Nordl. 1 Sept. 70 .

Anm. Könsorganernas antal 4 eller 8 i hvar blomma.

H. scorpioides L. Bl.: VII i slutet. Fr.: V i slutet och VI. Hanbl.: ej mogna, slutna anth:r Nordl. 17 Juli 70 ; anth:r något vissnade och färgade, de flesta dock slutna Angml. i slutet af Aug. 72; just mogna blr, åtminstone några anth:r bruna och tömda Ångml. 3 Aug. 70 och Hall. 28 Aug. 68. Honbl.: öfvermogna ark:r, ett befruktadt med ännu ofärgad hvit buk, de öfriga med friska fötter Hall. 28 Aug. 68.

Anm. Könsorganernas antal normalt 8, stundom 6. Könsorganerna äro hos denna art kanske störst bland alla Skandinaviska pleurokarpiska mossor och äro dessutom före mognaden vackert smaragdgröna, under det de andra löfmossornas könsorganer före mognaden vanligen äro ofärgade eller hafva en mycket svag, grön färgning.

H. incurvatum Schrad. Bl.: VII. Fr.: VII. Hanbl.: fjolårets hanblr funnos ännu qvar, i årets (han- eller hon?) blr voro ej ens parafyserna tydligt utvecklade Angml. 1 Juni 70; just mogna med en del anth:r oppna Gefle Juli 70; anth:r i en samkönad blomma fullt tömda 
Ångml. Aug. 71. Honbl.: fjolårets ännu qvar Ångml. 1 Juni 70; ark:r åtminstone stundom öppna Gefle Juli 70; flesta ark:r öppnade, ett hade, ehuru slutet, likväl antagit en brun färgning af kanalen Ångml. Aug. 71 ; vissnade ark:r Ångml. 23 Sept 73.

Anm. Könsorganernas antal 4 eller 8. På exemplar från Ångml. Aug. 71 funnos samkönade blr jemsides med enkönade!

Hypnum Blyttii Br. \& Sch. Ej sedd af förff. Förhåller sig troligen likt den föregàende.

H. Haldanii Grev. Bl.: (VIII), IX, (X). Fr.: IX, X. Frukt dock ej funnen i Sv. Hanbl.: blr just mogna med öppna eller slutna anth:r Finland, Österbotten Sept. 72. Honbl.: gamla New-York Aug. 68; just mogen blomma med öppna eller slutna ark:r Österbotten Sept. 72.

Anm. Arkegoniernas antal 10.

H. pratense Br. \& Sch. $B l .: \mathrm{V}$ i slutet i södra Sverige; VII i mellersta Skandinavien. Fr.: V i slutet och VI. Hanbl.: vissnade anth:r Gefle Juli? 68; just mogna med svärmande antherozoider Ångml. 10 Aug. 74. Honbl.: just mogna Ner. 30 Juni 70; öfvermogna ark:r, ett befruktadt med ofärgad buk Gefle Juli 70; just mogna med öppna eller slutna ark:r Ångml. 3 och 10 Aug. 74 .

Anm. Denna art skulle hafva dvärghanplantor. På exemplar från Gefle och från Ảngermanland har förf. dock, fastän han serskildt rigtade sin uppmärksamhet på detta förhållande, ej kunnat finna annat, än att hanblrna voro cauligeni. Möjligen hade sporerna till dessa hanblr, om de voro uppkomna från sporer, grott $\mathbf{i}$ bladvinklarne, på hvilket ställe de väl bäst qvarstanna. Förf. tviflar dock, att så var förhållandet, åtminstone i Ångml., der förf. hade tillfälle att noggrant studera arten $\mathrm{i}$ naturen.

H. Lindbergii Mitt. Bl.: VII i Ångml. Fr.: V i slutet och VI enligt förff. och $\mathrm{i}$ analogi med öfriga sump-Hypna. Honbl.: ark:rna fullformade, sällan redan öppna Ångml. 24 Juli 73 ; just mogna, öppna eller slutna ark:r Ångml. Aug 72.

Anm. Ark:nas antal normalt 8.

H. imponens H. $B l$.: VIII, IX. $F r$.: III enligt exemplar från Ner., enligt förff. på hösten. Hanbl.: mycket unga, slutna anth:r Ångml. 5 Juli 73; ännu slutna, men snart mogna anth:r Södml. 1 Sept. 68. Honbl.: fullformade, slutna och friska, dock bruna ark:r ÖG. omkring 1 Sept. 71; just mogna, öppna eller slutna ark:r ÖG. Sept.? 71; gamla blr, dock tydligen årets, ibland slutna och of ärgade vissnade ark:r Ner. Sept. 73.

Anm. Könsorganernas antal mycket vexlande. endast 5 anth:r funnos $i$ en hanblomma, $i$ en honblomma funnos deremot öfver 30 ark:r; troligen var ark:rnas antal 32 .

H. callichroum Brid. Bl.: VII-IX. Fr.: VI i slutet och VII. Honbl.: vissnade, fjolårets blr Lappon. orient. Juli 72; just mogna, åtminstone några ark:r öppna i hvar blomma Aalesund 11 Juli 68, Tromsö 22 Juli 68 och Nordl. 3 Sept. 70.

Anm. Arkegoniernas antal befans vara $12 \mathrm{i}$ några blommor. 
Hypnum cupressiforme L. $B l$.: IV (V). Fr.: III. Hanbl.: just mogna, öppna eller slutna anth:r Bodö 3 Juli 69. Honbl.: just mogna med slutna eller öppna ark:r Ner. 11 Maj 73, Boh. Juni 70, Ångml. 12 Juni 74 och Bodö 3 Juli 69 ; något öfvermognna, de befruktade ark:rna med hvit, ofärgad buk, de andra endast fötterna och nedersta delarne af bukarne ofärgade och friska Trondhjem 27 Juni 69; unga med fullformade, slutna ark:r ÖG. 3 Aug. 70 (blomning på abnorm tid!)

Anm. Arkegoniernas antal normalt 12. De voro mycket olikgamla i samma blomma på exemplaren från Ångml.

H. Heufleri Jur. $B l$.: IV eller V. Fr.: VII enligt Skand:s Flora. Hanbl.: öppna eller slutna anth:r Dovre 13 Juli 72. Honbl.: ung, endast ett ark. fullformadt, de öfriga antheridlika Dovre Juli 73; öppna eller slutna ark:r Dovre 14 Juli 70.

H. flexuosum Berggr. Ej sedd af förf.

H. Bambergeri Sch. Bl.: VIII?. Frukt okänd. Honbl.: dels gamla med förvissnade ark:r, dels en mycket ung blomma med ett par antheridlika arkegon-anlag Dovre Juli 73.

H. bamulosum Br. \& Sch. Bl.: (V) VI, VII. Fr.: VI i slutet och VII. Honbl.: just mogna med slutna, ofärgade ark:r eller öppna med färgad hals Nordl. Juli 70, Dovre Juli 73, Angml. 27 Juli 72 och Gudbrandsdalen 18 Aug. 68; öfvermogna ej gamla ark:r Dovre Juli 65, Nordl. 3 Sept. 70; öfvermogna med befruktade ark:r med ofärgade bukar Nordl. i början af Juli 1870 .

Anm. Arten synes kunna blomma under större delen af sommaren. Ark:rnas antal i hvar blomma är normalt 6 eller 8. Såsom ett ytterligare skäl för sin förmodan, att denna art troligtvis nästan uteslutande har dvärghanplantor och ej är monoik, făr förf. till de på sidan 9 anförda tillägga, att hanblrna synas vara mycket flyg. tiga, emedan inga sådana funnos på de talrika, fruktbärande exemplar, som förf. undersökt, hvaremot honblr vanligen talrikt förefunnos.

H. fastigiatum Brid. Bl.: IV i Nerike, VIII och IX i norra Skandinavien. Fr.: III i Ner., VII i slutet uti norra Skandinavien. Hanbl.: unga, slutna anth:r Nordl. 5 Aug. 70 och Ner. Sept. 69. Honbl.: dels fjolảrsblr med ett felslaget, befruktadt ark., dels årsblr med fullformade, slutna ark:r Nordl. 5 Aug. 70; öfvermogna ark:r med fot och nedre bukhalfva ännu ofärgade Finland ö. Botn Sept. 72.

H. pallescens (H.) P. B. Bl.: VIII (IX). Fr.: IX och X. Hanbl.: ung (han- eller hon-?) blomma med blott parafyser utvecklade Ångml. 10 Juli 74; tömda, bruna anth:r Ångml. Sept. och Okt. 73. Honbl.: fjolårsblomma med ett friskt befrukta.dt ark. och de öfriga med ännu tydligt friska fötter Ångml. 1 Juli 70; ett ark. öppet, de öfriga ännu slutna Ångml. 2 Sept. 74; öfvermogna med befruktade ark:r Ångml. Sept. och Okt. 73.

Brachythecium herjedalicum Lindb. Förf. lyckades ej finna blr hos denna art. Frukt obekant.

B. plicatum Br. \& Sch. Bl.: V. Fr.: III. Hanbl.: öfvermogna med tömda, bruna anth:r Schweitz Juni 61 och Nordl. 14-15 Aug. 70. 
Honbl.: vissnade ark:r Jemtl. 22 Juni 69; knappt öfvermogna ark:r, alla öppna och ett befruktadt mod ofärgad buk Nordl. 12 Juli 69 på någon höjd öfver hafvet; vissnade, dock tydligen års-ark:r Nordl. 27 Juli 70.

Anm. 16 ark:r räknades $i$ en blomma.

Brachythecium glareosum Br. \& Sch. Bl.: V, VI. Fr.: III. Hanbl.: slutna, ej mogna anth:r Öl. Juli 73. Honbl.: fullformade, slutna ark:r VG. 5 Juni 73.

B. albicans Br. \& Sch. Bl.: (IV), V, VI, (VII). Fr.: III. Hanbl.: ej mogna, slutna anth:r Ner. 15 April 73 och 11 Maj 73; ytterst unga (han- eller hon-?) blr Ångml. Okt. 73 och Södml. 20 Nov. 70. Honbl.: flera blr med fullformade, slutna ark:r Ner. 11 Maj 73 (utvecklade på abnorm tid!); just mogna med öppna eller slutna ark:r Ångml. 27 Juli 72 och Aug. 71.

Anm. Ark:rna normalt 16 i hvar blomma.

B. Mildei Sch. Bl.: VI. Fr.: III. Båda uppgifterna ex analogia från slägtets öfriga arter.

B. salebrosum Sch. Bl.: (VI?), VII, (VIII). Fr.: III. Hanbl.: unga, slutna anth:r Upsala Maj 68 och Ångml. 1 Juni 70; just mogna, öppna eller slutna anth:r Ångml. 19 Aug. 73; öfvermogna, tömda anth:r Angml. Okt. 73. Honbl.: gammal fjolårsblomma Upsala Maj 68; just mogna, öppna eller slutna ark:r Nordl. i början af Aug. 69, Angml. 19 Aug. 73, Nordl. 22 Aug. 74 (formen turgidum); öfvermogna, bukarne dock stundom ännu ofärgade hos de obefruktade ark:rna likasom hos' ett befruktadt Angml. Okt. 73.

Anm. 8 ark:r räknades $\mathrm{i}$ en blomma.

B. erythrorrhizon Sch. Bl.: VI ex analogia mest. Fr.: III ex analogia. Hanbl.: ej mogna, slutna anth:r Angml. Juni 71. Honbl.: dels ännu slutna ark:r, dels ett befruktadt ark. med hvit buk Ångml. 24 Juli 74.

Anm. De ofvannämnda iakttagelserna äro gjorda på exemplar samlade af Prof. Hj. Holmgren i Juni 1871 och med dem fullkomligt lika exemplar samlade af förf. 1874. Dessa exemplar äro dock osäkra; de äro dioika och torde derför blott vara former af $\mathrm{B}$. albicans.

B. collinum Br. \& Sch. Bl.: V, VI. Fr.: III. Hanbl.: ej mogna, slutna anth:r Dovre 6 Juli 70. Honll.: just mogna, slutna eller öppna ark:r Dovre 6 Juli 70 och Finm. 26 Juli 67 . Höjden öfver hafvet på dessa 2 lokaler obekant.

Anm. En del af de slutna anth:rna voro bruna och hade utseende af att vara felslagna och vissnade.

B. velutinum Br. \& Sch. Bl.: VI (VII). Fr.: III, (IV). Hanbl.: mycket unga (han- eller hon-?) blr Upsala Maj 70 och Angml. 4 Aug. 68; öfvermogna, vissnade anth:r Upsala Juli 71, Ångml. 4 Aug. 68 och ÖG. 19 Aug. 70; ej mogna, slutna anth:r Ångml. 4 Aug. 68. Honbl.: öfvermogna, vissnade ark:r Upsala Maj 70, Ångml. 4 Aug. 68 och ÖG. 19 Aug. 70; mogna blr med slutna eller öppna ark:r Upsala Juli 71 och Ångml. 18 Juli 74; blr dels med unga, befruktade ark:r, dels med öfvermogna med friska, ofärgade fötter Sk. Aug. 68.

Anm. Könsorganernas antal 4, 6, 8, 10 eller 14. 
Brachythecium trachypodium Br. \& Sch. Bl.: (VI?) VII. Fr.: III i analogi med slägtets öfriga arter. Hanbl.: just mogna, öppna eller slutna anth:r Lappon. orient. Aug. 72. Honbl.: just mogna, öppna eller slutna ark:r Lappon. orient. Aug. 72.

B. reflexum Br. \& Sch. Bl.: (V), VI. Fr.: III. Hanbl.: mycket unga (han- eller hon-?) blr Gefle Maj 69; öfrermogna med tomma, bruna anth:r Gefle Maj 69, Angml. Juni 73 och 30 Juli 68; ej mogna, slutna anth:r Ångml. Juni 73 och 18 Juli 74, Nordl. 6 Aug. 70; just mogna med öppna, fulla eller tomma anth:r Nordl. 20 Juli 70. Honbl.: unga, slutna ark:r Ner. 6 April 73 (utvecklade på abnorm tid!); helt och hållet vissnade ark:r Angml. Juni 73 och 30 Juli 68; mogna blr med öppna eller slutna ark:r Angml. i slutet af Juni 73 och 18 Juli 74; öfvermogna blr, ark:rna med åtminstone fötterna friska, stundom äfven befruktade ark:r Nordl. 20 Juli och 6 Aug. 70, Ångml. 18 Juli 74 och 30 Juli 68.

Anm. Anth:rna på exemplar från Nordl. 20 Juli 70 hade stundom, då de voro tömda, ej hunnit blifva helt och hållet brunfärgade, utan blott delvis, så att de voro lappigt bruna. 12 ark:r räknades $\mathrm{i}$ en blomma.

B. Starkei Br. \& Sch. Bl.: V, VI (VII). Fr.: III. Hanbl.: ej mogna, slutna anth:r Angml. Maj och Juni 70. Honbl.: just mogna med öppna eller slutna ark:r Ångml. 3 Aug. 73; öfvermogna, befruktade ark:r med hvit, ofärgad buk, de öfriga mer eller mindre vissnade eller stundom t. 0. m. slutna och ofärgade Ångml. Juni 73 och 3 Aug. 73.

Anm. 16 anth:r räknades $i$ en blomma. I en honblomma funnos $2($ !) befruktade ark:r, och på exemplaren från den 3 Aug. 73 voro i honblrna ark:rna ganska olikgamla, från ofärgade slutna till befruktade.

B. glaciale Br. \& Sch. Bl.: VI, (VII). Fr.: III. Hanbl.: ej mogna, slutna anth:r Nordl. 2 Aug. 70. Honbl.; just mogna Nordl. 2 Aug. 70. Dessa exemplar togos högt uppe i lafbältet.

B. rutabulum Br. \& Sch. Bl.; V (VI). Fr.: III. Hanbl.: ej mogna, slutna anth:r Ner. 6 April 73, Upsala Maj 69 och Södml. 15 Juni 68. Honbl.: vissnade fjolårsblr, stundom med felslagna befruktade ark:r Stockh. 11 Maj 68 och Södml. 15 Juni 68; fullformade slutna ark:r Södml. 15 Juni 68.

Anm. Angående årsblrnas läge se sid. 6 !

B. rivulare $\mathrm{Br}$. \& Sch. $B l .: \mathrm{V}$ i slutet och VI. Fr.: III. Honbl.: just mogna med öppna eller slutna ark:r eller ibland äfven något öfvermogna Sk. 1 Juli 71, ÖG. Juli 69, Nordl. 17 Juli 70, och 22 Aug. 70 samt Mdpd 21 Juli $74 ; \frac{1}{2}$ tum långa setor ÖG. omkring 1 Sept. 71. Anm. 16 ark:r räknades i flera blommor.

B. campestre Br. \& Sch. $B l$.: VI i analogi med slägtets öfriga arter. Fr.: III.

B. populeum Br. \& Sch. Bl.: V i slutet, VI (VII). Fr.: III. Hanbl.: ej mogna, slutna anth:r Ångml. 1 Juni 70, 4 Juli 72 , Juli 73 och 18 Juli 74; just mogna, öppna, ej tömda anth:r Nordl. 14 Aug. 70. Honbl.: blott ett par ark:r fullformade, men slutna Ångml. 18 Juli 74; 
just mogna blr med öppna eller slutna ark:r Dal. 24 Juli 46, Nordl. 20 Juli 70 och 14 Aug. 70; öfvermogna och temligen vissnade ark:r Ångml. 4 Juli 72 och Juli 73; vissnade ark:r Ångml. 1 Juni 70.

Anm. 8 anth:r räknades $\mathrm{i}$ ett par blommor. De vissnade ark:rna från Ångml. 1 Juni 70 voro stundom ofärgade.

Brachythecium plumosum Br. \& Sch. Bl.: (V i slutet) VI (VII, VIII). Fr.: III (och IV i början). Hanbl.: anth:r just mogna och öppna, ännu otömda Nordl. 4 Juli 70 och Ångml. 8 Juli 73; ej mogna, slutna anth:r Nordl. 17 Juli 69 ; flesta anth:r tömda och bruna, några ännu ej tömda Stockh. 27 Sept. 68. Honbl.: just mogna med öppna eller slutna ark:r Ångml. 5 Juli 72 och Stockh. 27 Sept. 68; linielånga setor uppstickande ur blrna Trondhjem 5 Aug. 68.

Anm. Stockholms-exemplaren af den 27 Sept. 68 synas hafva blifvit ovanligt mycket försenade.

Camptothecium lutescens Br. \& Sch. Bl.: V i slutet och i början af VI. Fr.: III. Honbl.: ark:r snart mogna, fullformade och slutna Upsala Maj 69 och Gotl. Juni 65 (på senare stället ett ark. t. o. m. öppet); öfvermogna, vissnade ark:r, ett t. 0 . m. slutet med ofärgad hals, alla tydliga års-ark:r Sk. 16 Dec. 70.

Anm. 16 ark:r räknades i ett par blommor.

C. nitens Sch. Bl.: VIII och IX enligt blr och i analogi med andra i kärr växande pleurokarpiska mossor. Fr.: V i slutet. Hanbl.: ej mogna, slutna anth:r Lappon. orient. Aug. 72. Honbl.: gamla och vissnade ark:r Ner. 8 Jan. 73.

Anm. Blrna synas hos denna art, likasom hos de flesta andra $\mathrm{i}$ kärr växande pleurokarpiska mossorna, vara ganska flygtiga. Atminstone har förf. haft mycket svårt att finna blommor på de talrika exemplar af denna mossa, som han haft att tillgâ.

Amblystegium riparium Br. \& Sch. Bl.: V i slutet, VI (VII). Fr.: V i slutet och VI i början. Hanbl.: ej mogna, slutna anth:r Uppl. Juni 70; anth:r dels slutna, dels öppna, ej tömda, dels öppna, tömda och bruna Gefle Juli 70. Honbl.: dels gamla, troligen fjolårsblr, dels just mogna med öppna eller slutna ark:r Uppl. Aug. 72; något öfvermogna, ett ark. befruktadt med ofärgad buk, de öfriga med friska fötter Gefle Juli 70.

A. trichopodium (Schultz). Bl.: liktidigt med den föregående? Fr.: VI och VII mest enligt förff.

Anm. A. Kochii Br. \& Sch. är, såsom varande enligt Prof. Lindberg blott en form af den föregående, troligen liktidig med densamma.

A. filicinum Lindb. $B l .: \mathrm{V}$ i slutet-VII. Fr.: V (VI). Hanbl.: en mycket ung (han- eller hon-?) blomma VG. 9 Juni 73 ; öfvermogna, tomma och bruna anth:r Nordl. 7 Juni 69 och Gotl. Juli 69 ; just mogna blr med öppna, ej tömda eller med slutna anth:r Ångml. 14 Juli 68, Uppl. 20 Juli 68 och Lappon. orient. Aug. 72. Honbl.: något öfvermogna ark:r, dock åtminstone fötterna friska Nordl. 7 Juli 69 (blomning på abnorm tid?), Nordl. 6 Aug. 69 och 2 Sept. 70; just mogna med 
slutna, ofärgade ark:r eller öppna med färgad hals Mdpd 21 Juli 74 och Lappon. orient. Aug. 72.

Anm. Ark:s antal 6 i 2 blr från Mdpd.

Amblystegium irriguum Sch. Bl.: VIII och IX mest i anal. med sumpHypna. Fr.: V mest enligt förff. Hanbl.: just mogna ÖG. i Aug.

A. fluviatile Sch. Bl.: VIII och IX. Fr.: V enligt förff. Hanbl.: unga, slutna anth:r ÖG. Aug.; öfvermogna, tömda anth:r Stockh. Sept. 70. Honbl.: just mogna, med öppna eller slutna ark:r Stockh. Sept. 70.

A. radicale $\mathrm{Br}$. \& $\mathrm{Sch}$. Bl.: VI i analogi med följ. Fr.: IV \& V mest enligt förff.

A. serpens Br. \& Sch. Bl.: (V), VI(-IX). Fr.: (IV), V(-VIII). Hanbl.: anth:r ej mogna, slutna Wien 27 Maj 61 (A. Juratzkae), Ångml. 28 Juni 74, Boh. Juli 69, Norrtelje 5 Juli 67; mogna med öppna eller slutna anth:r Ångml. 2 Juni och 1 Sept. 74 . Honbl.: gamla, fjolårets Sköfde 2 Juni 73; mogna med öppna eller slutna ark:r Angml. 28 Juni och 1 Sept. 74; öfvermogna, ark:r med ännu ofärgade, friska bukar Mdpd 21 Juli 74.

Anm. A. Juratzkae Sch. och finnmarchicum (Lor.) blomma och fruktsätta troligen, såsom varande enligt Prof. Lindberg blott former af denna art, liktidigt med densamma.

A. enerve Br. \& Sch. Bl.: VII i analogi med följ. Fr.: VII enligt förff. Ej sedd af förf.

A. confervoides Br. \& Sch. Bl.: VII. Fr.: VII i början. Hanbl.: just mogna, ett anth. t. 0 . m. tömdt Tyskland Röhngebirge 11 Aug. 72; tomma anth:r Nordl. i björkregionen 27 Aug. 70. Honbl.: öfvermogna blr, ett ark. befruktadt med ännu of ärgad nedre del af buken, ett par obefruktade t. 0. m. ännu med friska bukar Nordl. 27 Aug. 70.

Anm. Könsorganernas antal normalt 4.

A. subtile Br. \& Sch. Bl.: VI, VII. Fr.: VII. Hanbl.: gamla, endast fjolảrsblr Ångml. 29 Juni 74; ej mogna, slutna anth:r VG. 20 Maj 72; mogna, slutna eller öppna anth:r Sk. 20 Juli 72. Honbl.: flera blr med starkt utveckladt perichetium och befruktade, gröna ark:r VG. 20 Maj 72; ibland halfvuxna fruktskaft Ångml. 29 Juni 74; just mogna eller nảgot öfvermogna blr med slutna, öppna eller unga, ark:r befruktade Sk. 20 Juli 72.

Anm. Könsorganernas antal 4 eller 6 .

A. Sprucei Br. \& Sch. Bl.: VII i analogi med de 2 föregående. Fr.: VII.

Plagiothecium undulatum Br. \& Sch. Bl.: VIII och IX. Fr.: IX, X. Hanbl.: 2 mycket unga (han- eller hon-?) blr Nordl. 2 Juli 70; just mogna med slutna eller öppna, fulla eller tömda anth:r Trondhjems st. 12 Sept 70. Honbl.: fjolårsblomma med ett felslaget, befruktadt ark. Trondhj:s st. 12 Sept 70.

Anm. 32 anth:r räknades $\mathrm{i}$ en blomma.

Pl. silvaticum Br. \& Sch. Bl.: VIII och IX. Fr.: VIII-X.

Anm. Observationerna på denna art äro antecknade vid den nästa, emedan fört. ej kan finna någon skilnad på dessa 2 arter och do dessutom med afseende på tiderna för blomning och fruktmognad förhålla sig lika. 
Plagiothecium denticulatum Br. \& Sch. Bl.: VIII och IX. Fr.: VIII-X. Hanbl.; mycket unga Jemtl. 23 Juni 70. Honbl.: gamla, fjolårets blr Jemtl. 23 Juni 70; just mogna, med öppna eller slutna ark:r Angml. Aug. 72 och Nordl. 3 Sept. 70; öfvermogna, befruktade, linielånga ark:r Ångml. Sept. 72.

Pl. laetum Br. \& Sch. Bl.: VII och VIII. Fr.: VII i Nordlanden. Hanbl.: snart mogen, ett anth. öppet Nordl. 27 Aug. 70. Honbl.: öfvermogna, ett befruktadt ark. med of ärgad buk Nordl. 10 Aug. 69; just mogna, alla ark:r öppna Nordl. 27 Aug. 70.

Pl. piliferum Br. \& Sch. Bl.: VI (och VII) i Nordl., VII-IX i Sverige. Fr.: VI och VII i Nordl., (VI-) VIII och IX i Sverige. Honbl.: ej fullt mogna, slutna anth:r Nordl. 17 Juli 69 och Ångml. 3 Aug. 73; just mogna blr, anth:r ofärgade och slutna eller öppna, färgade eller ofärgade Nordl. i medlet af Aug. 70; tömda, bruna anth:r Angml. Okt. 73; mycket ung (han- eller hon-?) blomma med blott parafyser utvecklade Angml. Sept. 73. Honbl.; mogna med slutna eller öppna ark:r Nordl. 17 Juli 69 och medlet af Aug. 70, Angml. Sept. 73; helt och hållet vissnade ark:r Angml. 3 Aug. 73 och 0kt. 73 samt Nordl. Aug. 70.

Anm. Könsorganernas antal 6, (7) eller 8. Samkönade blr funnos på ett par exemplar; sådana hafva förut inom slägtet blifvit funna hos Pl. nitidulum enligt Bryol. Eur.

Pl. Mühlenbeckii Br. \& Sch. Bl.: VI i Nordl., VIII-X i Ångml. Fr.: V i slutet och VI i Nordl., (VIII) - X i Angml. Hanbl.: slutna, ej mogna anth:r Nordl. 3 Juli 70, Angml. 8 Juli 73 (mycket unga) och 17 Sept. 74; anth:r öfvermogna, tomma Nordl. 8 Juli 70 och 31 Aug. 70 ; just mogna, slutna eller öppna anth:r N. Romsdalen Juli 72. Honbl.: just mogna, öppna eller slutna ark:r Nordl. 8 Juli 70 och Ångml. 17 Sept. 74; fullformade, slutna ark:r N. Romsdalen Juli 72; öfvermogna med befruktade, hvit-gröna ark:r Nordl. 31 Aug. 70.

Pl. silesiacum Br. \& Sch. Bl.: VII mest i början. Fr.: VI i midten och slutet, (VII i början). Hanbl.: ej mogna, slutna anth:r VG. 8 Juni 73 och Ångml. Aug. 71; mogna, öppna eller slutna anth:r ÖG. Juli 69 och 10 Aug. 70. Honbl.: mogna med öppna eller slutna ark:r Ångml. Aug. 71; öfvermogna med unga befruktade ark:r ÖG. 10 Aug. 70.

Pl. turfaceum Lindb. Bl.: VII i analogi med föregående. Fr.: (VI?), VII.

Pl. nitidulum Br. \& Sch. Bl.: VII--VIII. Fr.: (V i slutet) och VI i Nordl., (VIII och IX), X i Angml. Hanbl.: ej mogna, slutna anth:r Nordl. 4 Juli 70 och Ängml. Okt. 73. Honbl.: gamla Ångml. 1 Juni 70; temligen olikgamla, från slutna, ofärgade till helt och hållet vissnade ark:r Nordl. 14 Aug. 70; öfvermogna, ett ark. befruktadt och grönt Ångml. Okt. 73 .

Pl. elegans Br. \& Sch. Blr ej funna af förf. Frukt ej funnen i Skandinavien.

Rhynchostegium depressum Br. \& Sch. Bl.: V i analogi med $\mathrm{Rh}$. tenellum Br. \& Sch. Fr.: III mest i analogi med andra för hösten af förff. angifna arter. 
Rhynchostegium rusciforme Br. \& Sch. Bl.: V i slutet. Fr.: (I och III), III. Hanbl.: ej mogna, slutna anth:r Goti. Juni 65. Honbl.: mogna, öppna eller slutna ark:r Skottland Juni 73.

Anm. Parafyser $\mathrm{i}$ honblrna ovanligt långa, längre än ark:rna.

Rh. murale Br. \& Sch. Bl.: V i början. Fr.: III. Hanbl.; mogna, med slutna eller öppna anth:r Sk. 26 Maj 72. Honbl.: alla ark:r fullformade, snart mogna med tydlig kanal Sk. 26 Maj 72.

Rh. tenellum Br. \& Sch. Bl.: V. Fr.: V. Hanbl.: ej mogna, slutna anth:r Gotl. Juni 65. Honbl.: mogna med slutna eller öppna ark:r Gotl. Juni 65; öfvermogna, temligen vissnade ark:r Öl. 26 Juni 67.

Eurhynchium Teesdalii Lindb. Bl.: V i analogi med föreg. Fr.: V?

E. praelongum Br. \& Sch. $B l$.: VII i början, mest i analogi med den följande. $F r .:$ (II) III. Honbl.: fruktskaft nästan fullt utvecklade Ner. Sept. 72.

E. Schleicheri Lor. Bl.: VII i början. Fr.: III. Honbl.: fjolårs, vissnad bl. VG. 6 Juni 73 ; fullformade, slutna ark:r ÖG. 27 Juli 73.

Anm. 16 ark:r räknades $\mathrm{i}$ en blomma.

E. Stokesii Br. \& Sch. Bl.: VII i början. Fr.: III. Dock är frukt ej ännu funnen i Sverige. Honbl.: dels fjolårs, vissnade blr, dels årets med oftast ännu slutna, fullformade ark:r Södml. Juli 70.

E. piliferum Br. \& Sch. Bl.: VII. Fr.: III. Hanbl.: ej mogna, slutna anth:r Ångml. 17 Juli 74. Honbl.: ung, dock med åtminstone ett ark. fullformadt Ångml. Juni 69 (utvecklad på abnorm tid!); mycket vackra, mogna blr med slutna eller öppna ark:r ÖG. 27 Juli 73; öfvermogna blr, endast fötterna friska Gefle Aug. 68.

Anm. 16 ark:r räknades i flera blr.

E. Vaucheri Br. \& Sch. Bl.: VII. Fr.: III. Honbl.: öfvermogna, dock stundom ett och annat ark. slutet och ofärgadt ÖG. Aug. 71 .

E. crassinerve Sch. Bl.: VI, VII. Fr.: III. Hanbl.: ej mogna, slutna anth:r Göteborg 4 Juli 68; just mogna, en del anth:r öppna Trondhjem 27 Juni 70.

E. velutinoides $B r$. \& Sch. $B l .:$ (VI), VII i analogi med de flesta andra Eurhynchia. Fr.: III ex analogia och enligt förff.

E. striatum Br. \& Sch. Bl.: V, (VI). Fr.: III. Hanbl.: nyss tömda anth:r ÖG. Juli 69. Honbl.: årsblr snart mogna med åtminstone några öppna ark:r VG. 8 Juni 73; årsblr med unga, ej fullformade ark:r Trondhj. st. 24 Juni 69 ; öfvermogna med ett ungt befruktadt ark., de öfriga frisk fot ÖG. Juli 69 .

Anm. Hanblomman var caulogen, ej nanandrisk. Ark:rnas antal är normalt 16.

E. striatulum Br. \& Sch. Bl.: (IV i slutet) och V. Fr.: III enl. förff. Honbl.: i en blomma ark:rna litet öfvermogna med oftast ännu ofärgade, friska bukar, dessutom unga blr med blott parafyser utvecklade Gotl. Juni 65.

Anm. 16 ark:r räknades $\mathrm{i}$ en blomma.

E. strigosum Br. \& Sch. Bl.: III i slutet, (IV). Fr.: III i slutet. Hanbl.: ej mogna, slutna anth:r Stockh. Juli 70 (utvecklad på abnorm tid!). Honbl.: snart eller just mogna med slutna eller öppna ark:r Sundsvall 12 Maj 74, Ångml. 1 Juni 70 och Stockb. 21 Maj 64; öfver- 
mogna med unga, befruktade ark:r med ännu ofärgad buk Ångml. 6 Juni 74 och Östersund 23 Juni 70.

Anm. Hanblomman var caulogen, ej nanandrisk. Ark:rnas antal var $i$ en blomna 12. I de många helt förvissnade honblr, som förf. sett, voro de vissnade ark:rna ofta slutna.

Eurhynchium diversifolium Br. \& Sch. Bl.: III i slutet, (IV). Fr.: III i slutet. Honbl.: något öfvermogna, dock ett par ark:r ännu friska och slutna Dovre 26 Juni 70.

Thamnium alopecurum Br. \& Sch, Bl.: V. Fr.: III. Frukt dock ej funnen $\mathrm{i}$ Sv. och N. Hanbl.: anth:r stora, snart mogna Danmark Maj 53. Honbl.: snart mogna med några ark:r öppna VG. 6 Juni 73.

Homalothecium sericeum Br. \& Sch. Bl.: IV-(VI). Fr.: III. Hanbl.: just mogna, anth:r slutna, ofärgade eller nära tömda, färgade Ångml. 8 Juni 69; öfvermogna med tömda anth:r VG. 5 Juni 73. Honbl.: något öfvermogna blr, stundom äfven med befruktade, gröna ark:r VG. 5 Juni 73, Boh. Juli 69 och ÖG. Juli 64; just mogna blr med alla eller några ark:r öppna och friska Ångml. 29 Juni 74, Smål. Juli 69; troligen öfvermogen, dock några ark:r slutna Nordl. 2 Sept. 70.

Anm. Ark:rnas antal 12 eller 16. Hos arten förekomma ofta slutna, vissnade ark:r.

Isothecium myurum Brid. Bl.: III, (IV). Fr.: III. Hanbl.: gamla, dock ej alltid fullt tömda anth:r Ner. 8 Jan. 73; just mogna med slutna eller öppna, fulla eller tömda anth:r Uppl. Maj 68 och 70. Honbl.: mogna med slutna eller öppna ark:r Uppl. 12 April 74 samt Maj 68 och 70, Gestr. Juni 60 samt Nordl. 3 Juli 70; öfvermogna ark:r med friska fötter Ångml. 2 och 15 Juni 74; ett befruktadt med ögat synligt ark. ÖG. 4 Aug. 70; gamla Angml. Sept. 73 och Trondhj:s st. Sept. 70.

Anm. Ark:rnas antal är ganska vexlande; oftast uppgår det till 14 eller 16, ibland kunna de deremot vara ytterst sparsamma eller t. o. m. ensamma i hvar blomma. Vissnade ark:r ofta slutna. Honparafyser i mogna och öfvermogna blr gulaktiga.

I. myosuroides Brid. Bl.: III, (IV). Fr.: III (-VI). Hanbl.: gamla Ner. Juni 68. Honbl.: ej mycket öfvermogna, nedre bukhalfvan på alla frisk och ofärgad Ångml. 4 Juli 72; öfvermogna, temligen vissnade ark:r, vanligen endast fötterna friska VG. 5 Juni 73 och Ner. Juni 68; gamla, vissnade Stockh. 22 Maj 64 och Trondhj:s st. Sept. 70.

Orthothecium rufescens Br. \& Sch. Bl.: VII i slutet eller på gränsen mellan VII och VIII. Fr.: VIII och IX. Hanbl.: mycket unga Schweitz Juni 61 och Dovre Juli 73. Honbl.: dels vissnade fjolårsblr, dels friska årets med åtminstone några ark:r öppna Nordl. 8 Aug. 70 .

Anm. Hanparafyser gula. Honparafyser likaså i öfvermogna blr. 10 ark:r räknades i en blomma.

O. chryseum Br. \& Sch. Bl.: VII i slutet eller på gränsen mellan VII och VIII. Honbl.: dels gamla, fjolårets, dels årets med fullformade, oftast slutna, ibland äfven öppna ark:r Nordl. 2 och 20 Aug. 70. På senare stället togs den i björkregionen.

An̄. 4 ark:r räknades $\mathrm{i}$ ett par blr. Först efter blommans mognad blifva honparafyserna gula. 
Orthothecium lapponicum (Sch.) Bl.: liktidig med föregåendes? Ej sedd af förf. Frukt ej känd.

o. strictum Lor. $B l$.: på gränsen mellan VII och VIII i analogi med slägtets öfriga arter. Frukt obekant. Honbl.: gamla Lul. Lapm. 27 Juli 67.

O. intricatum Br. \& Sch. Bl.: på gränsen mellan VII och VIII. Fr.: VIII och IX enligt förff., $\nabla$ enligt ex. från Trondhjem. Honbl.: gamla Nordl. 6 Aug. 70; ark:r fullformade, slutna Nordl. 22 Aug. 70.

Pylaisia polyantha Sch. Bl.: (III), IV, (V). Fr.: I-III. Hanbl.: ej mogna, slutna anth:r Uppl. Juli 71 (blr utvecklade på abnorm tid!); just mogna med åtminstone nảgra öppna anth:r Ångml. 6 Juni 69 och Uppl. Dec. 73. Honbl.: ännu unga, sällan med fullformade, öppna ark:r Ångml. 6 Juni 69 och 15 Juni 74; öfvermogna, ett ark. befruktadt med hvit buk Ångml. 7 Juni 74; gamla Uppl. Dec. 73 .

Thedenia suecica Br. \& Sch. Blr ej sedda af förf. Fr.: V eller VI enligt förff.

Cylindrothecium concinnum Sch. Bl.: V, (VI). Fr.: III i analogi med andra för hösten af förff. angifna löfmossor. Frukt dock ej funnen i Skand. Hanbl.: unga med ovanligt små anth:r Dovre 23 Juli 72; honblr snart mogna, fullformade ark:r Nordl. 5 Juli 70; mogna med slutna eller öppna ark:r Dovre Juli 65; föga öfvermogna ark:r Dovre 23 Juli 72.

Anm. 7 ark:r räknades $\mathrm{i}$ en blomma.

Platygyrium repens Br. \& Sch. Bl.: V, (VI). Fr.: III. Hanbl.: mycket unga (han- eller hon-?) blr Stockh. 2 Juni 64. Honbl.; gamla Stockh. 2 Juni $64 ; 2$ olikgamla blr, den nedre vissnad, men dock årets, ty den hade friskt perigyn, den öfre yngre med fullformade, slutna ark:r Ner. 30 Juni 70.

Leucodon sciuruides Schwægr. Bl.; VI. Fr.: III. Honbl.: mycket unga, ett par halfvuxna ark: $r$ syntes dock redan Heidelberg 12 Juni 50 ; just mogen, endast ett par ark:r ännu slutna N. Molde 8 Juli 72; fullånga fruktskaft Bergens st. 25 Aug. 67.

Anm. 16 ark:r räknades $\mathrm{i}$ en blomma. Honparafyser gula; enligt Bryol. Europ. skulle parafyser saknas i honblrna.

Climacium dendroides WM. Bl.: $\mathrm{V}$ och i början af VI. Fr.: III. Hanbl.: ej mogna, slutna anth:r Gefle Maj 70 och Uppl. 24 Maj 70; gamla med tomma anth:r Jemtl. 22 Juni 70; mogna med svärmande antherozoider Ångml. 10 Juli 74. Honbl.: gamla Christiania April 68, Uppl. 24 Maj 70, Jemtl. 22 Juni 70 och Angml. 2 Sept. 74.

Anm. Anth:rna ovanligt talrika, men räknades dock ej i någon blomma. Han- och honparafyser vid blrnas mognad gula.

Lescuraea saxicola Milde. $B l$.: VII-IX. Fr.: III eller IV enligt förff. Hanbl.: gamla Dovre 23 Juli 72; dels just mogna, dels temligen unga anth:r Dovre Juli 72. Honbl.; gamla Jemtl. Areskutan 22 Juni 69; just mogna blr med öppna ark:r Lappon. orient. Aug. 72; dels gamla blr, dels en ung ofvan de gamla med fullformade ark:r Nordl. 24 Aug. 69.

Anm. 11 ark:r räknades $\mathrm{i}$ en, $20 \mathrm{i}$ en annan blomma. 
Antitrichia curtipendula Brid. Bl.: (IV), V, (VI), Fr.: III. Hanbl.: ej mogna, slutna anth:r VG. 10 Juni 73 och Ångml. 15 Juli 68 ; tömda eller snart mogna anth:r Angml. 19 Aug. 74 (dessa sista blr synas vara utvecklade på abnorm tid!). Honbl.: ung med urskiljbara ark:r Uppl. Maj 70; fullformade, slutna ark:r VG. 1 Juni 73; ett par ark:r redan öppna, de öfriga slutna VG. 10 Juni 73.

\section{Ordn. Neckeraceae.}

Neckera pennata $H . \quad B l .: \mathrm{V}$ i slutet. Fr.: III. Hanbl.: unga, knappt fullformade anth:r Gefle Juni 59; temligen gamla blr, flesta anth:r öppna och tomma, några dock slutna, men bruna Stockh. Juni 53; öfvermogna, tomma anth:r Ner. 14 Juli 62 och 15 Aug. 70. Honbl.: något öfvermogna, dock tydliga årets blr Gestr. Juni 69 ; ett befruktadt med hvit-grön buk, de öfriga friska fötter och bukar Ner. 14 Juli 62.

N. oligocarpa Br. \& Sch. Bl.: (III), IV, V(-VII). Fr.: III. Hanbl.: ej mogna, slutna anth:r Lul. Lapm. Juni 64; flesta anth:r slutna, dock inblandade tomma och bruna Östersund 2 Juni 68; mogna, ej fullt tömda anth:r Jemtl. Juli 70; dels gamla blr, dels ofvan dessa unga blr med slutna anth:r Angml. 19 Aug. 74. Honbl.: just mogna blr Östersund 2 Juni 68, Lul. Lapm. Juni 64, Dovre Juli 65 och Ångml. 19 Aug. 74; öfvermogna blr, ark:r med temligen friska fötter Jemtl. Juli 70, Helsl. Juli 71 och Luleå 27 Juni 67 ; gamla blr N. Gudbrandsdalen Aug. 68; unga gröna frukter Angml. 19 Aug. 74.

Anm. Mycket svår, likt andra Neckerae, att bestämma blomningstiden för, emedan könsorganerna så hastigt antaga ett vissnadt ntseende vid öfvermognad, och emedan blr synas kunna alstras bela sommaren igenom. Afvissnade ark:r äro hos slägtets arter ofta slutna.

N. pumila H. $B l$. : IV. Fr.: III, dock frukt ej funnen i Sverige. Hanbl.: flera mycket unga (han- eller hon-?) blr Sk. 24 Juni 71. Honbl.: just mogna blr VG. Mösseberg 20 Maj 72; temligen gamla blr, dessutom fruktskaft af full längd Baden-Baden Aug. 73.

N. crispa H. $B l .:$ V. Fr.: III. Hanbl.: gamla Christiania 25 Maj 67; mogna med fulla eller tomma anth:r Verml. Juli 67 och ÖG. 20 Juli 45. Honbl.: gamla, dock ej alltid öppna ark:r Christiania 25 Maj 67, Gotl. 31 Juli 69 och Sk. 20 Aug. 71; blr synas vara årets och hafva ej fullkomligt vissnade ark:r Sm. Juni 68; befruktade ark:r ännu oftast med ofärgad buk Sk. Juli 60 .

N. complanata Hüb. Bl.: V. Fr.: III. Hanbl.: gamla Ner. 21 Nov. 72. Honbl.: något öfvermogna blr, fötter och ibland äfven bukar ofärgade och friska Sk. 24 Juni 70; gamla ÖG. 20 Aug. 72.

N. Besseri Jur. Bl.: $\mathrm{V}$ i analogi med öfriga Neckerae, IX enligt exemplar. Fr.: III ex analogia, dock frukt ej funnen i Skand. Hanbl.: en ung blomma ofvan gamla N. Gudbrandsdalen 19 Aug. 68. Honbl.: ofvan gamla blr en ung med slutna, fullformade ark:r Tyrolen Sept. 67.

Homalia trichomanoides Br. \& Sch. Bl.: III och IV. Fr.: III (och början af IV). Hanbl.: de flesta blrna med slutna, ofärgade anth:r, ibland dock inblandade tomma och bruna anth:r Sk. 6 Maj 73 och VG. 1 och 6 Juni 73. Honbl.: gamla Ner. 11 April 72; öfvermogna blr med be- 
fruktade, ofärgade eller gröna ark:r Sk. 6 Maj 73 och VG. 1-6 Juni 73; dels gamla blr, dels snart mogna med fullformade ark:r, dels derofvan unga med blott parafyser Angml. 2 Juni 74; öfvermogna, dock tydligen årets blr Ångml. 5 Juli 73; ett par linier långa fruktskaft uppsticka Ner. 8 Juli 74.

Anm. 4 eller 8 könsorganer räknades i några blr. Hos denna, likasom hos Neckerae, synes blommorna ofta utvecklas i akropetal följd på samma årsskott, så att de högre sittande årsblrna äro yngre, än de längre.

\section{Ordn. Fabronaceae.}

Habrodon Notarisii Sch. $B l .: \mathrm{V}$ eller VI ex analogia; inga blr funna hos arten af förf. $F r$.: III enligt förff., dock ej funnen med frukt i Skandinavien.

Myrinia pulvinata Sch. $B l .:$ VIII. Fr.: VII enligt exemplar, III enligt förff. Hanbl.: ej mogna, slutna anth:r Verml. 22 Okt. 53. Honbl.: en blomma med ett befruktadt ark. med grön buk Verml. 22 0kt. 53.

\section{Ordn. Pterogoniaciae.}

Pterogonium gracile Sw. $B l .: \mathrm{V}$ eller VI ex analogia. Fr.: III mest enligt förff., frukt dock ej funnen i Skand. Hanbl.: gamla Boh. Juli 64 .

Anm. Hanparafyser gula.

Pterigynandrum filiforme H. Bl.: VII, (VIII). Fr.: VII i Sverige, VIII och IX i Nordl. Hanbl.: unga Ångml. 4 Juli 72; mogna med åtminstone några öppna anth:r Uppl. Juli 71. Honbl.: snart mogna, fullformade ark:r Uppl. Juli 71; mogna med öppna eller slutna ark:r Nordl. 14 Aug. 70; öfvermogna, ark:r med friska fötter ÖG. 20 Aug. 70.

\section{Ordn. Leskeaceae.}

Thujidium tamariscinum Br. \& Sch. Bl.: VII. Fr.: (I-)III. Honbl.: dels gamla fjolårets, dels friska årets med öppna ark:r ÖG. 11 Aug. 73; snart mogna, ett ark. öppet, de öfriga slutna Bergens st. Juli? 73 .

T. delicatulum Br. \& Sch. Bl.: VI. Fr.: V i slutet och VI. Honbl.: blr med ark:r af ett tvifvelaktigt utseende, dock troligen gamla Ångml. 14 Juni 70, Juli 72, 27 Juni 74 och Aug. 68 samt 0G. 4 Aug. 70; utom fjolårs blr unga med blott parafyser tydliga Ångml. Juni 72; unga blr, med outvecklade ark:r eller stundom t. $0 . \mathrm{m}$. fullformade slutna eller oppna ark:r Ångml. 17 Juli 74; mogna, öppna eller slutna ark:r Gefle Juli 70.

Anm. De gamla ark:rna blifva ofta affärgade och få ett förvillande utseende af att vara friska. 12, 16 och öfver 20 ark:r räknades.

T. abietinum Br. \& Sch. Bl.: VII i början. Fr.: III eller IV mest enligt förff. Hanbl.; just mogna, öppna eller slutna anth:r Ångml. 27 Juli 72. Honbl.: dels gamla honblr, dels snart mogna med slutna ark:r Ångml. 27 Juli 72.

Anm. 16 ark:r räknades $i$ en blomma. 
Thujidium Blandowii Br. \& Sch. Bl.: (VI), VII i slutet. och VIII. Fr.: VI (VII). Hanbl.: ej ån mogna, slutna anth:r Ångml. Aug. 71 och ÖG. 2 Aug. 73; några anth:r redan öppna Ångml. 17 Juli 74. Honbl.: just eller snart mogna med åtminstone några ark:r öppna ÖG. 2 Aug. 73, Angml. Aug. 71 och Nordl. 14 Aug. 70.

T. decipiens De Not. Ej undersökt af förf.

T. gracile Br. \& Sch. Bl.: ej undersökt. Fr.: VIII och IX.

Heterocladium dimorphum Br. \& Sch. Bl.: på gränsen mellan VII och VIII. Fr.: III. Hanbl.: gamla Ångml. 8 Juli 73; unga Ångml. i början af Aug. 72. Honbl.: med fullformade, slutna ark:r Ångml. 3 Aug. 73 och 12 Aug. 74 .

H. heteropterum Br. \& Sch. Bl.: VII. Fr.: III i analogi med andra af förff. för hösten angifna mossor; frukt dock ej funnen i Skand. Honbl.: dels gamla, dels snart mogna, men blott ett ark. redan öppet N. Aalesund 11 Juli 68.

H. Kurrii Br. \& Sch. Bl.: VII ex analogia. Fr.: V enligt Hn, III ex analogia. Ej sedd af förf.

Pseudoleskea tectorum Sch. Blr ej sedda af förf. Frukt ej känd.

P. catenulata Br. \& Sch. Bl.: (IV)-IX. Fr.: VII enligt förff., dock frukt ej funnen i Skand. Honbl.; dels mogna, dels något öfvermogna VG. 9 Juni 73; just mogna med slutna eller öppna ark:r Nordl. 3 Juli och 2 Sept. 70; knappt öfvermogna ÖG. omkring 1 Sept. 71.

Anm. 8 ark:r normalt i hvar blomma.

P. atrovirens Br. \& Sch. Bl.: V, (-VII). Fr.: III. Hanbl.: ej mogna med slutna anth:r Ångml. 16 Juni 74, Nordl. 27 Juli och 14 Aug. 70; mogna, en del anth:r öppna Nordl. 12 Juli 69; dels gamla blr, dels unga Angml. 19 Aug. 73. Honbl.: just mogna Ångml. 29 Juni 74 och Nordl. 14 Aug. 70; blr dels just mogna, dels föga öfvermogna med befruktade ark:r med ofärgad buk Nordl. 12 Juli 69 på någon höjd öfver hafvet.

Anomodon apiculatus Br. \& Sch. Bl.: VI i analogi med den följande. Fr.: III, dock ej funnen med frukt i Sverige. Honbl.: gamla VG. 1 Juni 73.

A. viticulosus Hook \& Tayl. Bl.: VI i slutet. Fr.: (I, II ibland i södra Sverige), III. Hanbl.: unga, snart mogna VG. 6 Juni 73; gamla Danmark Dec. 52. Honbl.: gamla och vissnade VG. 6 Juni 73 och Mdpd 21 Juli 74; mycket unga, endast få ark:r fullformade, slutna, de öfriga rudimentära Öl. Juli 70 och Mdpd 21 Juli 74; just mogna Bergens st. Juli? 73.

A. attenuatus Hüb. Bl.: VI i slutet, mest ex analogia. Fr.: III. Hanbl.: ej mogna, slutna anth:r N. Levanger 24 Juni 69; öfvermogna, tomma anth:r Uppl. Juli 71. Honbl.: vissnade Ner. 11 Maj 73.

A. longifolius Hn. Bl.: VI i slutet. Fr.: III. Hanbl.: tomma anth:r Mdpd 21 Juli 74. Honbl.: mycket unga blr, blott parafyser synliga Gotl. Juni 65 och Ångml. 29 Juni 74; fjolårsblr med vissnade ark:r, ofta affärgade och slutna Ångml. 1 Juni 70, 8 Juni 69 och 29 Juni 74. 
Leskea polycarpa Ehrh. Bl.: VIII. Fr.: VII. Hanbl.: snart mogna, slutna anth:r Ner. Sept. 72. Honbl.: dels just mogna blr, dels öfvermogna med befruktade ark:r med hvit buk Ner. Sept. 72.

L. nervosa Myr. Bl.: III i slutet-VI. Fr.: VII. Hanbl.: ej mogna, slutna anth:r Ångml. ૪ Juni 69 ; just mogna blr med öppna eller slutna anth:r Ångml. Juli 73. Honbl.: mogna blr med öppna eller slutna ark:r Ångml. 8 Juni 69 och 8 Juli 72; ark:r ännu slutna Nordl. 17 Juli 70; vissnade ark:r, synas dock vara årets? VG. 2 Juni 73 och Ångml. 27 Juli 72.

Myurella julacea Br. \& Sch. Bl.: VII. Fr.: VII. Hanbl.: ej mogna, slutna anth:r ÖG. 1 Juli 68; öfvermogna, tomma anth:r Boh. 2 Juli 69. Honbl.: snart eller just mogna ark:r Dovre Juli 73; endast gamla blr Nordl. 14 Aug. 70 .

M. apiculata Br. \& Sch. Bl.: VII. Fr.: VII. Honbl.: dels gamla från förra året, dels årets med fullformade och ibland t. $0 . \mathrm{m}$. öppna ark:r Dovre Juli 73.

Anm. Årsblrna sitta hos Myurella nedom färggränsen och afsticka bjert genom sina mörka, rödbruna hylleblad från de gula vegetativa bladen.

\section{Ordn. Hookeriaceae.}

Hookeria lucens Sm. Bl.: VI. Fr.: III. Hanbl.: just mogna med öppna eller slutna anth:r N. Aalesund 3 Juli 72. Honbl.; mogna med oppna eller slutna ark:r Aalesund 3 Juli 72.

Anm. Könsorganernas antal normalt 6. Denna art är den enda af våra pleurokarpiska mossor, som har klubblika hanparafyser, hvilket utseende de få derigenom, att den öfversta cellen är såväl längre som vidare, än de andra. Ark:rna äro dessutom hos arten ovanligt korta och tjocka. Årets han- och honblr sitta dessutom hos denna mossa, likasom hos Thujidium Blandowii, blandade om hvarandra; hos andra monoika pleurokarpiska mossor har förf. alltid funnit årets hanblr sitta ofvanför årets honblr.

\section{Ordn. Fontinalaceae.}

Dichelyma falcatum Myr. Bl.: VII, (VIII i början). Fr.: VII. Hanbl.: ej mogna, slutna anth:r Mdpd 22 Juli 74; just mogna Ångml. 19 Aug. 73. Honbl.: just mogna med öppna eller slutna ark:r Mdpd 22 Juli 74 och ÖG. 17 Aug. 70; öfvermogna, ett ark. befruktadt med ảnnu ofärgad buk Ångml. 19 Aug. 73.

A nm. Könsorganernas antal normalt 6 eller 8. Ark:rna äro äfven hos denna mossa, likasom äfven hos Fontinales, relativt kortare och tjockare, än hos de öfriga pleurokarpiska mossorna utom Hookeria.

D. capillaceum Br. \& Sch. Bl.: VII i analogi med föreg. Fr.: VII enligt förff.

Fontinalis antipyretica L. $B l$.: VI och början af VII. Fr.: (IV) -början VII. Honbl.: snart mogna, ibland med öppna ark:r Angml. 5 Juli 72; något öfvermogna, dock temligen friska ark:r Smål. Aug. 66 ; gamla Sődml. Aug. 69. 
H. Wilh. Arnell.

Fontinalis gracilis Lindb. Bl.: VI. Fr.: (IV)-början VII. Honbl.: mycket ung (han- eller hon-?) bl. ÖG. 7 Juni 72; öfvermogna blr, dock tydligen årets Lappon. orient. Juli 72.

F. dalecarlica Br. \& Sch. Bl.: VI. Fr.: VI och VII. Hanbl.: gammal, fjolårets Ångml. 8 Juli 73. Honbl.: snart mogna, fullformade ark:r Ångml. 5 Juli 72.

F. hypnoides Hn. Bl.: VI. Fr.: VI och VII. Honbl.: öfvermogna, men ännu friska ark:r, ett befruktadt med gröngul buk Gefle Aug. 71.

\section{Musci acrocarpi. \\ I. Musci stegocarpi.}

\section{Ordn. Buxbaumiaceae.}

Buxbaumia indusiata Brid. Bl.: VII i analogi med följande. Fr.: (IV), V.

B. aphylla L. $B l$.: VII? $F r_{\text {.: }} \mathrm{IV},(\mathrm{V})$. Honbl.: en frukt fullformad, eljest unga fruktskaft af alla storlekar uppstickande, somliga t. $0 . \mathbf{m}$. knappt nående ofvan perichetiet Ångml. 31 Aug. 74 .

Dipbyscium foliosum Mohr. Bl.: VI, (VII?). Fr.: VI, VII. Honbl.: unga, ej ännu fullformade ark:r N. Romsdalen 28 Juni 72; endast ett ark. fullformadt, de öfriga rudimentära Ner. 5 Juli 69.

Anm. Angående denna mossas egendomliga honparafyser se Schimper: Recherches anatomiques et morphologiques sur les mousses», sidd. $37-38$ och tab. VI, figg. $42-46$.

\section{Ordn. Georgiaceae.}

Tetraphis pellucida H. $B l .:$ IV. $F r .:$ (V i slutet), VI(-IX). Hanbl.: anth:r tömda, ej gamla VG. 8 Juni 73. Honbl.: unga, dock några ark:r fullformade, men slutna Ångml. Juni 68; ark:r af olika ålder, från mycket unga till ett befruktadt med hvit buk VG. 8 Juni 73; gamla ark:r, dock fötter ännu friska Ångml. 4 Juli 72; gamla Sk. 25 Juni 71 och ÖG. 10 Aug. 70.

Tetrodontium Brownii Schwægr. Bl.: inga blr undersökta af förf. Fr.: III-V?, dock har förf. ej kommit till någon säker åsigt från exemplar; andra förff:s uppgifter äro högst stridiga.

\section{Ordn. Polytrichaceae.}

Polytrichum commune L. Bl.: V. Fr.: VII. Hanbl.: just mogna, öppna anth:r Ångwl. Juni 68; tömda anth:r Uppl. omkring 1 Aug. 67. Honbl.: fullformade, slutna ark:r Ångml. Juni 68 och 21 Juni 74. 
Anm. Hos Polytricha förekomma de längsta könsorganerna bland våra mossor. Anth:rna ses lätt med blotta ögat, likaså ark:rna, hos hvilka senare halsarne äro oproportionerligt långa. Egendomlig är äfven den stora olikheten $i$ könsorganernas antal $i$ han- och honblrna, $\mathrm{i}$ de förra säkert öfver 50 , i de senare normalt 4 .

Polytrichum juniperinum W. Bl.: V i slutet och VI i början. Fr.: VI, (VII). Hanbl.: ej mogna, slutna anth:r Angml. 16 Juni 74 (* strictum); just mogna, de flesta anth:r tömda Ångml. 5 Juli 74 ; tomma anth:r Angml. 19 Aug. 73. Honbl.: unga blr med blott parafyser Ångml. 16 Juni 74 (* strictum); fullformade, ännu slutna ark:r Mdpd 2 Juli 68; öppna, öfvermogna ark:r Nordl. 31 Juli 70 (* strictum).

P. piliferum Schreb. Bl.: (IV), V. Fr.: (V i slutet), VI. Honbl.: unga, åtminstone ett ark. fullformadt Ångml. 16 Juni 74; ett befruktadt, hårigt ark. Nordl. 4 Juli 70.

P. formosum H. Bl.: V i slutet och VI i början. Fr.: VII. Hanbl.: ej alla anth:r tömda Ångml. 30 Juli 73; tomma anth:r Ångml. Juli och 19 Aug. 73. Honbl.: ett befruktadt ark. redan ymnigt hảrigt Ångml. 19 Ang. 73.

P. gracile Menz. Bl.: V i slutet och VI i början. Fr.: VI. Hanbl.: ej alla anth:r ännu tömda ÖG. 9 Juli 70 ; bruna, vissnade, dock slutna anth:r Uppl. Juli 71; tomma anth:r Ångml. Aug. 72. Honbl.: unga, ej ännu fullformade ark:r Sk. 25 Juni 71 ; öfvermogna, föga vissnade ark:r, ett befruktadt med ofärgad buk Ångml. 25 Juli 73.

P. sexangulare Flörke. Bl.: V och VI ex analogia. Fr.: VI och VII ex analogia och enligt förff.

Pogonatum alpinum Röhl. Bl.: V i slutet, VI, (VII).' Fr.: VII. Honbl.: befruktadt, hårigt ark. Ångml. 30 Juli 73; öfvermogna, delvis bruna ark:r Nordl. 4 Aug. 70; just mogen, öppna eller slutna ark:r Ångml. 3 Aug. 73 (utvecklad på abnorm tid!)

P. urnigerum P B. Bl.: III i slutet. Fr.: (XI), XII-II. Hanbl.: just mogna, ej alla anth:r tömda Ångml. Maj 70. Honbl.: fullformade ark:r, ett öppet Ångml. Maj 70; öppna, friska ark:r Ångml. i början af Juni 69; öfvermogna med befruktade, håriga ark:r med ofärgad buk Ångml. 15 Juni 74; unga fruktskaft uppsticka Ångml. 17 Juli 74.

P. capillare Brid. Bl.: III i analogi med föreg. Fr.: (XII-)II.

P. aloides P B. Bl.: IV, (V). Fr.: II i slutet och III i början. Hanbl.: snart öfvermogen, dock ej alla anth:r fullt tömda Södml. 10 Juni 68. Honbl.: nảgot öfrermogna, ett befruktadt, hårigt ark. Södml. 10 Juni 68; ark:r föga öfvermogna, ett befruktadt med ofärgad buk N. Aalesund 2 Juli 72 ; halfvuxna fruktskaft ÖG. 13 Juli 73.

P. nanum P B. Bl.: IV, (V). Fr.: II i slutet och III i början. Hanbl.: snart mogna, dock ej öppna anth:r VG. 5 Juni 73. Honbl.: ark:r med öppna kanaler VG. 5 Juni 73.

Oligotrichum laevigatum $\mathrm{Br}$. \& Sch. $B l$.: V i analogi med följ. Fr.: IV.

o. bereynicum Lam. \& Dc. Bl.: V. Fr.: IV. Hanbl.: snart mogen, ett par anth:r t. 0. m. tömda Trondhjem 27 Juni 70 . Honbl.: just mogen, ett par ark:r öppna Trondhjem 27 Juni 70. 
Catharinea undulata WM. Bl.: V. Fr.: (XI)-II. Hanbl.: өj mogna, slutna anth:r Ångml. 8 Juni 69 och 12 Juni 74. Honbl.: atminstone några ark:r fullformade, slutna Ångml. 12 Juni 74; fullformade, öppna ark:r Ångml. 7 Juli $74 ; 2$ befruktade, temligen stora ark:r, de öfriga dock ännu temligen friska Hall. 26 Aug. 68 (rätt tid?); halfvuxna fruktskaft Ångml. 8 Aug. 74.

C. tenella Röhl. $B l .:$ IV i slutet och V i Trondhj:s st.; på gränsen mellan VI och VII i Ångml. Hanbl.: flesta anth:r tömda, de andra åtminstone öppna Trondhj:s st. 26 Juni 70 (omkring 1000 fot öfver hafvet); ej mogna, slutna anth:r Ångml. 16 Juni och 4 Juli 74; just mogna, öppna anth:r, dock inga tömda Ångml. Juli 72. Honbl.: just mogna, slutna eller öppna ark:r Trondhj:s st. 26 Juni 70; unga blr med blott parafyser Ångml. 4 Juli 74; alla eller några ark:r öppna Ångml. Juli 72 och 27 Juli 74.

Anm. Ark:rnas antal hos denna art, likasom hos alla Polytrichaceae, normalt 4 .

\section{Ordn. Bryaceae.}

Timmia austriaca H. Bl.: gränsen mellan IV och V, (VI). Fr.: VII. Hanbl.: med slutna eller öppna, fulla anth:r Östersund 23 Juni 70; dels tömda, bruna anth:r, dels of ärgade, just öppna Ångml. 3 Aug. 73. Honbl.: föga öfvermogna, öppna ark:r Östersund 23 Juni 70 ; något mera öfvermogna ark:r, dock ännu friska Ångml. 30 Juli 73 .

Anm. H،ınparafyser, såsom Prof. Lindberg redan förut anmärkt, spadlika af flera, jemsides stående cellrader mot spetsen.

T. havarica Hessl. Bl.: IV i slutet och V. Fr.: VI. Hanbl.: ej mogna, slutna Dovre Juli 72; just mogna, slutna eller öppna anth:r Nordl. 9 Juli 69. Honbl.: just mogna, slutna eller oppna ark:r Dovre Juli 72; olikgamla ark:r, några t. 0. m. antherid-lika, unga, de flesta dock öppna Nordl. 9 Juli 69.

T. megapolitana H. $\beta$ norvegica Lindb. Blr ej funna af förf. Frukt ej känd.

Breutelia arcuata Sch. Bl.: VI. Fr.: VIII och IX enligt Syn. musc. och Skand:s Flora. Hanbl.: just mogna med fulla eller tomma anth:r Bergens st. Juli 73.

Philonulis fontana Brid. Bl.: (VI), VII mest i början. Fr.: VI, (VII). Hanbl.: snart mogna, ett par anth:r redan öppna Sk. 14 Juni 71; ej mogna, slutna anth:r Mdpd 20 Juli 74. Honbl.: just mogna, slutna eller öppna ark:r Ångml. 3 Aug. 72; något öfvermogna, öppna ark:r Hall. 29 Aug. 68.

A nm. Honparafyser i öfvermogna blr gula.

P. calcarea Sch. Bl.: (VI i slutet), VII i början. Fr.: VI, (VII). Hanbl.: just mogna, anth:r öppna, ej tömda ÖG. Juli 69 . Honbl.: just mogna, slutna eller öppna ark:r ÖG Juli 69.

P. capillaris Lindb. $B l .:$ och $F r .:$ ex analogia liktidiga med föreg:s. Frukt ej funnen i Sverige.

Conostomum boreale Sw. V i slutet. Fr.: VI, (VII). Hanbl.: ej mogna, slutna anth:r Angml. 1 Juni 70 och 29 Juni 74; flesta anth:r 
tőmda Nordl. 23 Juli 70; tomma anth:r Ångml. Aug. 71. Honbl.: ark:r fullformade, ett t. 0 . m. öppet Ångml. 29 Juni 74 ; öfvermogna, ark:r blott fötter friska Nordl. 4 Aug. 70 och Ångml. i början af Aug. 71 .

Anm. Unga anth:r, åtminstone straxt före mognaden, rödbruna ej ofärgade, såsom hos de flesta andra löfmossor. Honparafyser i mogna blr gula.

Bartramia Halleri H. $B l$. . VI, (VII). Fr.: V. Hanbl.: snart mogna, blott ett anth. öppet ÖG Juli 69. Honbl.: gamla Jemtl. 23 Juni 70 ; snart mogna, blott ett ark. öppet ÖG. Juli 69; öfvermogna, ett ark. befruktadt med ofärgad buk Dovre Aug. 72.

B. erispa Sw. Bl.: VI, (VII). Fr.: (IV), V. Hanbl.: just mogna, ott anth. redan helt och hållet tömdt Nordl. Juli 69 ; tömda ÖG. 4 Aug. 70. Honbl.: fullformade, slutna ark:r Sk. 2 Juli 71; just mogna blr Nordl. Juli 69; öppna och friska ark:r ÖG. 4 Aug. 70.

B. Normanni (Holmgr.) $B l .:$ VI. Fr.: V. Hanbl.: tomma anth:r Finm. 28 Juli 68. Honbl.: något öfvermogna, dock ett ark. ännu slutet och friskt Finm. 28 Juli 68.

Anm. Arten är monoik; anth:r och ark:r sitta inom skilda hyllen. Hanparafyser gula, honparafyser ofärgade.

B. Oederi Sw. Bl.: VI, (VII). Fr.: V. Blr: snart mogna med fullformade, slutna könsorganer Jemtl. 23 Juni 70; snart mogna, anth:r slutna, ett par ark:r öppna Nordl. Juli 69; öfvermogna, anth:r tömda, ark:r med åtminstone fötterna friska och ett befruktadt med grön buk N. Gudbrandsdalen Juli 73.

B. ityphylla Brid. Bl.: VI. Fr.: (IV), V. Blr.: könsorganer ej ännu utvecklade, endast ett antherid-likt arkegon-anlag syntes $N$. Levanger 24 Juni 69; könsorganer vanligen fullformade, men alla slutna Ångml. 7 Juli 74 .

Anm. Parafyser dels gula (han-?), dels ofärgade (hon-?).

B. breviseta Lindb. Bl.; VI ex analogia. Fr.: V.

Gymnocybe turgida Lindb. $B l$.: IV (och början af V). Fr.: (VI?), VII. Hanbl.: öfvermogna, nästan alla anth:r tömda Dovre 11 Juli 72. Honbl.: något öfvermogen, några ark:r med blott fötterna friska, andra helt och hảllet friska, ett t. 0. m. slutet Nordl. 3 Juli 70 ; just mogen, åtminstone några ark:r öppna Lappon. orient. 12 Juli 72.

G. palustris Fr. Bl.: IV i slutet, (V i början). Fr.: på gränsen mellan VI och VII. Hanbl.: öfvermogna, flesta anth:r tömda ÖG. 2 Juli 70. Honbl.:, just mogna ark:r slutna eller öppna Uppl. 13 Juni 68 , Angml. Juni 68 och 6 Juni 74 ; öfvermogna, ark:r dock med atminstone fötterna friska, de befruktade med ofärgad buk ÖG. 2 Juli 70.

Aulacomnium androgynum Schwægr. Bl.: IV(-VI). Fr.: VII i borjan. Hanbl.: gamla Gotl. Juni 65. Honbl.: med slutna eller öppna, friska ark:r VG. 6 Juni 73, Gotl. Juni 65 och Stockh. Juli 70 (rätt tid?); på Gotlands-ex. voro ark:rna i några andra blr ganska vissnade, s̊̊ att endast fötterna voro friska.

Anm. 16 ark:r räknades i en blomma. Honparafyser gula.

Paludella squarrosa Ehrh. Bl.: på gränsen mellan VII och VIII. Fr.: VII. Hanbl.: just mogna, slutna eller öppna anth:r Ångml. i början af Aug. 71. Honbl.: just mogna, slutna eller öppna ark:r Ångml. 
i början af Angusti 71; öfvermogna, ark:r med endast fötterna friska ÖG. omkring 1 Sept. 71 .

Anm. Hanparafyser spadlika, de tre öfversta cellerna dubbla.

Meesia tristicha Br. \& Sch. Bl.: VI. Fr.: VI och början af VII. Hanbl.: snart mogna, slutna anth:r Angml. 20 Juli 74 . Honbl.: just mogna, slutna eller öppna ark:r Ångml. 20 Juli 74.

Anm. Anth:r gulbruna redan före mognaden; hanparafyser gula, klubblika eller jemnbreda. Ark:na få hos denna och de flesta följande Bryaceae ej en brun, utan en vacker purpur-violett färgning vid mognaden. Parafyslika celltrådar finnas hos arten, likasom hos de flesta Splachnaceae, uti honblrna, och hafva dessa en del celler violetta, andra deremot ofärgade.

M. longiseta $\mathrm{H}$. Bl.: VI. Fr.: VI, (VII). Blr: samkönade, könsorganer fullformade, slutna ÖG. Juli 70; snart mogna, några könsorganer redan öppna Ner. Juli 69; öfvermogen, tomma anth:r, ett befruktadt ark. med grön buk Ångml. 3 Aug. 70 .

M. uliginosa $\mathrm{H}$. $B l .:(\mathrm{V})$, VI normalt. Fr.: normalt VI och VII. Blr: honblr nảgot öfvermogna, dock oftast hela bukarne ofärgade Gefle Juli 70 ; en honbl. med ett långt, grönt, befruktadt ark., en hanbl. med tomma anth:r Nordl. i början af Juli 70; honblr med nyss befruktade ark:r med ofärgad buk Nordl. 19 Juli 70; en samkönad bl, anth:r tomma, ark:r mycket olikgamla från unga, antheridlika till befruktade, gröna Nordl. 27 Juli 70.

Amblyodon dealbatus PB. $B l .: \mathrm{V}$ i slutet och i början af VI. $F r_{\text {.: }}$ VI. Bl $r$ hanblr just mogna med fulla eller tomma anth:r Tromsö 17 Juli 68; honblr något öfvermogna, dock ark:rna med friska bukar Dovre 23 Juli 72.

Catoscopium nigritum Brid. Bl.: VII. Fr.: VII. Honbl.: gamla ÖG. 22 Juli 70, Nordl. 29 Juli 70 och Dovre 4 Aug. 68; ej så gamla, ark:r med friska fötter Nordl. 4 Juli 70 ; ark:r med friska fötter, ett befruktadt och grönt Nordl. 19 Juli 69; just mogna, slutna eller öppna ark:r Nordl. 1 Aug. 70.

Anm. 4 ark:r räknades $i$ ett par blr. Denna art synes använda 2 år på fruktutvecklingen; dock har förf. ej kommit till full klarhet i denna sak.

Cinclidium stygium Sw. $B l$. : V i slutet. Fr.: VI, oftast mest mot slutet. $B l r$ : öfvermogna, dock ej alla anth:r tömda, ark:r med friska bukar Ångml. 5 Juli 72; öfvermogna, anth:r tomma, ark:r nftast blott fötterna friska, ibland äfven befruktade Gefle Juli 71, Nordl. 24 Juli och 10 Aug. 70 .

C. subrotundum Lindb. $B l$.: V i slutet. Fr.: VI, mest mot slutet. Blr: öfvermogna, dock ett anth. ännu slutet, ark:r stundom befruktade med ofärgad buk Mdpd 20 Juli 74.

C. areticum Br. \& Sch. $B l$ och Fr.: ex analogia liktidiga med de 2 forregåendes.

Mnium subglobosum Br. \& Sch. $B l .: \mathrm{V}$ liktidigt med den följandes ex analogia. Fr.: III i slutet och IV i början. 
Mnium punctatum L. $B l .:$ V i början. Fr.: III i slutet och IV i början. Hanbl.: just mogna, fulla eller tomma anth:r Nordl. 5 Juli 69. Honbl.: just mogna, slutna eller öppna ark:r Ångml. 14 Juni 70 och Bodö 5 Juli 69.

M. hymenophylloides Hüb. Bl.: VI, (VII). Frukt ej känd. Honbl.: gammal fjolărsblomma Nordl. 19 Juli 70; öfvermogen, ett arkegon dock ännu friskt och slutet, men med brunfärgad hals Nordl. 6 Aug. 70.

Anm. Honparafyser trådlika, gula.

M. hymenophyllum Br. \& Sch. Bl.: VI, mest ex analogia. Fr.: ej känd. Hanbl.: just mogna, fulla eller tömda anth:r Nordl. 6 Aug. 70 (omkring 2000 fot öfver hafvet.)

M. Blyttii Br. \& Sch. Bl.: V eller VI ex analogia. Fr.: (IV), V.

M. rostratum Schrad. $B l .: \mathrm{V}$ ex analogia. Fr.: IV i slutet och V i början.

M. cuspidatum H. $B l$. : V och VI. Fr.: IV och V. Blr: unga, blott anth:r ännu utvecklade och synliga Upsala Maj 70, Södml. 8 Juni 69, Ångml. 8 Juni 69 och 29 Juni 74 samt ÖG. 13 Juni 70 ; snart mogna med ännu slutna anth:r och fullformade, stundom redan öppna ark:r VG. 8 Juni 73; ännu slutna anth:r och ark:r Mdpd 21 Juli 74 (senår!).

M. medium Br. \& Sch. Bl.: V. Fr.: IV i slutet. Blr: snart mogna med fullformade, slutna könsorganer Ångml. 14 Juni 70 och 15 Juni 74.

M. affine Bland. Bl.: V. Fr.: IV i slutet. Hanbl.: ej mogna, anth:r slutna VG. 6 Juni 73; snart mogna, några anth:r öppna, men inga tömda Östersund 23 Juni 70; tomma anth:r ÖG. 26 Aug. 70. Honbl.: fullformade, slutna ark:r VG. 6 Juni 73 och Upsala i slutet af Juni 71; vissnade ark:r med friska fötter ÖG. 26 Aug. 70.

M. undulatum $\mathrm{H}$. $B l$.: $\mathrm{V}$ ex analogia. Fr.: IV i slutet.

M. hornum L. Bl.: V. Fr.: på gränsen mellan IV och V. Hanbl.: snart mogna, slutna anth:r VG. 5 Juni 73 ; tomma anth:r Ångml. 30 Juli 73. Honbl.: dels slutna, dels öppna, friska ark:r VG. 5 Juni 73; öfvermogna, ark:r med blott fötterna friska Ångml. Juli 73.

M. spinosum Schwægr. Bl.; V. Fr.: IV och V ex analogia. Honbl.: unga med fullformade, slutna ark:r Östersund 23 Juni 70.

M. serratum Brid. $B l .: \mathrm{V}$ i slutet. $F r_{\text {: }} \mathrm{V}$. Blr: just mogna, åtminstone några anth:r och ark:r öppna 0̈l. 20 Juni 67.

M. riparium Mitt. $B l$. och $F r .:$ V ex analogia. Ej sedd af förf.

M. orthorrynchum Br. \& Sch. Bl.; V. Fr.: V, mest ex analogia. Hanbl.: ej mogna, slutna anth:r Nordl. 11 Juli 70 i videbältet.

M. inclinatum Lindb. $B l$. och $F r .: \mathrm{V}$ ex analogia.

M. stellare H. Bl.; V i slutet och VI. Fr.: V. Honbl.: ark:r fullformade, slutna Gefle Juli 71; just mogna, öppna ark:r Gefle Juni 70.

M. cinclidioides Hüb. Bl.: V i slutet. Fr.: (IV i slutet), V. Hanbl.: ej mogna, slutna anth:r Ångml. Juni 72; öppna, men ännu ej tömda anth:r Ångml. 5 Juli 72. Honbl.: fullformade, slutna ark:r Ångml. Juni 72; slutna eller öppna ark:r Ångml. 5 Juli 72. 
Zieria julacea Sch. Bl.: V. Fr.: (VIII), IX. Honbl.: mogna med öppna, stundom ännu ofärgade ark:r Nordl. 13 Juli 73; ark:r med friska bukar, något vissnade halsar Dovre Juli 73 .

Z. demissa Sch. $B l_{\text {. }} \mathrm{V}$ i analogi med föreg. Fr.: VIII och IX. Anomobryum julaceum Sch. $B l$.: VI. Fr.: X, frukt dock ej funnen i Skand. Honbl.: just mogna, slutna eller öppna ark:r N. Aalesund Juli 73.

A. concinnatum Lindb. $B l_{\text {.: }}$ VI i analogi med föreg. Frukt ej känd.

Bryum roseum Schreb. Bl.: IV. Fr.: (II), III. Hanbl.: gamla Ångml. Juli 72. Honbl.: nảgot öfvermogna, dock ännu friska ark:r Ångml. 16 Juni 74 och i slutet af Juni 73.

B. pseudotriquetrum Schwægr. Bl.: VI, VII. Fr.: VI i slutet och VII i början. Hanbl.: ej mogna, slutna anth:r Nordl. 12 Juli 69; just mogna, flesta anth:r tömda Angml. Aug. 72; tömda anth:r Ångml. 25 Juli 73. Honbl.: något öfvermogna med friska, öppna ark:r ÖG. Juli 68, Ångml. Aug. 72 och Nordl. 14 Aug. 70.

A nm. 16 ark:r räknades $i$ en blomma. Könsorganer och parafyser blifva hos denna art, likasom hos de de flesta andra Brya, vid öfvermognad vackert rosenröda.

B. pallens Sw. Bl.: V i slutet och VI. Fr.: (XI)-II. Hanbl.: anth:r snart mogna, slutna Ångml. 5 Juli 72. Honbl.: slutna eller ōppna, friska ark:r ÖG. Juli 69; något öfvermogna ark:r Nordl. 10 Juli 74.

B. Duvalii Voit. $B l$. : VI och början af VII. Fr.: VI. Honbl.: slutna eller opppna, friska ark:r Ångml. Juli 72.

Anm. 16 ark:r räknades $\mathrm{i}$ en blomma. jandes.

B. subrotundum Brid. $B l$. och Fr.: ex analogia liktidiga med föl-

B. pallescens Schleich. Bl.: (VI), VII. Fr.: VI, VII. Hanbl.: snart mogna, slutna anth:r Nordl. 11 Juli 70; just mogna, slutna eller öppna anth:r Ångml. i slutet af Juli 72. Honbl.: just mogna eller något öfvermogna ark:r Ångml. 3 Aug. 73; öfvermogna ark:r Nordl. 22 Aug. 70.

B. bimum Schreb. Bl.: VI. Fr.: VII i början. $B l r$ : samkönade, anth:r ej mogna och slutna, ark:r öppna med färgad eller ofärgad hals N. Gudbrandsdalen Juli 73; samkönade med tömda anth:r och öppna, friska ark:r Ångml. 25 Juli 73.

B. cirrhatum Hornsch. Bl.: V i slutet och VI. Fr.: VI, VII. Blr: samkönade med nyss tömda anth:r och friska, öfvermogna ark:r Nordl. 19 Juli 70.

B. intermedium Brid. Bl.: V och VI. Fr.: VIII-X. Blr: samkönade med nyss tömda anth:r och ett befruktadt ark. med grön buk Nordl. 17 Juli 70.

Anm. Använder på fruktutvecklingen 14 till 15 månader.

B. microstegium Br. \& Sch. Bl.: VI ex analogia. Fr.: VI och VII enligt förff.

B. turbinatum H. Bl.: VI ex analogia. Fr.: (V), VI. 
Bryum caespiticium L. Bl.: VI. Fr.: V i slutet och VI. Honbl.: unga, blott en del ark:r fullformade Ångml. Juni 72 .

B. Mildei Jur. Svenska exemplar synas vara fullkomligt sterila.

B. Mühlenbeckii Br. \& Sch. Bl.: VII. Fr.: VII. Hanbl.: ej ånnu mogna, slutna anth:r Ångml. 3 Aug. 73. Honbl.: fullformade, slutna ark:r Mdpd 22 Juli 74; flesta ark:r öfvermogna och något vissnade, några fả dock ännu friska Uppl. 21 Aug. 67.

Anm. Hanparafyser hos denna art och den följande gula.

B. alpinum L. $B l .:(\mathrm{V}$, VI), VII i början. Fr.: VII i slutet. Hanbl.: gamla, tomma anth:r Blek. Juli 72. Honbl.: ung med åtminstone ett fullformadt ark. VG. 9 Juni 73 (abnorm tid!); fullformade, slutna ark:r Stockh. Juli 70; något öfvermogna, oftast helt friska ark:r Blek. Juli 72.

B. atropurpureum Br. \& Sch. Bl.: V i analogi med Webera pulchella m. fl. Fr.: V.

B. Klinggraeffii Sch. $B l$.: $\mathrm{V}$ likt föreg.? Fr.: $\mathrm{V}$, mest enligt förff.

B. erythrocarpum Schwægr. Bl.: V i slutet och VI. Fr.: VIIIX. Hanbl.: ej mogna, anth:r slutna Ångml. 4 Juli 72. Honbl.: öfvermogna, dock ett ark. ännu friskt och ofärgadt Ångml. 4 Juli 72.

B. capillare L. Bl.: VII. Fr.: VII. Honbl.: öfvermogen, ark:r dels slutna, ofärgade, dels ett befruktadt med ofärgad buk Gefle Aug. 70 ; öfvermogen bl. med olikgamla ark:r, ett befruktadt med grön buk, ett befruktadt med ofärgad buk, de öfriga slutna eller öppna och litet vissnade Sk. 1 Aug. 72.

B. cyclophyllum Br. \& Sch. Bl.: V eller VI ex analogia. Fr.: $\nabla$ och VI enligt förff.

B. argenteum L. $B l .: \nabla$ eller VII i slutet? Fr.: II. Hanbl.: snart mogna anth:r VG. 2 Juni 72; just mogna, anth:r slutna eller öppna Ångml. 10 Aug. 74. Hanbl.: just mogna, ark:r slutna eller öppna Ångml. 10 Ang. 74 .

Anm. Blomningen torde hos denna art infalla liktidigt med den följandes, eller under Solståndstiden. De unga frukterna hänvisa äfven derpå, i det man redan i Aug. träffar fullformade frukter. I Ảngml. funnos likväl inga årets blommor på talrika exemplar, insamlade på olika dagar af Juli månad 1874. Möjligen behöfver derför arten 18-19 månader för fruktens utveckling och blommar normalt i Aug.?

B. Funckii Schwægr. Bl.: IV i slutet och V. Fr.: V i slutet. Honbl.: just mogna, ark:r slutna eller öppna Gefle Juni 73.

ii. pendulum Sch. $B l .:$ V i slutet-början af VII. Fr.: VI, VII. $B l r .:$ samkönade, anth:r ännu slutna, ark:r temligen gamla och öfvermogna Finm. 17 Juli 68.

Anm. Hos denna art och den följande förefinnes en tydlig proterogyni, så att arkegonierna äro mogna långt före antheridierna. Äfven hos andra mossor med samkönade blr förefinnes ofta en tendens till proterogyni, likasom äfven stundom hos de monoika arterna. Jfr sidd. $11-12$ och sid. 17. 
Bryum inclinatum Bland. $B l .:$ V-början af VII. $F r .:$ VI, VII. $B l r .:$ samkönade blr, anth:r slutna och temligen unga, åtminstone några ark:r oppna Ångml. 24 Juni 72; anth:r unga och slutna, ark:r öppna och ett t. 0 . m. befruktadt Ångml. 8 Juli 73 ; flesta anth:r slutna, ett dock tömdt, de flesta ark:rna deremot öfvermogna Stockh. Juli 70; öppna eller slutna anth:r och ark:r Ångml. 30 Juli 73; anth:r tomma, ark:r öfvermogna och ett befruktadt Nordl. 10 Aug. 70.

B. Warneum Bland. Bl.: ej undersökt af förf. Fr.: V och IX-X.

B. lacustre Bland. Bl.: VI (och VII?). Fr.: V-VII. Blr: en honblomma med fullformade, slutna ark:r Lul. Lapm. 27 Juli 67.

B. calophyllum $\mathrm{R}$. Br. $B l$.: exemplar af arten från Trondhjem och Finm., hvilka äro de enda Skandinaviska med angifven insamlingstid, som förf. sett, syntes helt och hållet sakna blr. Fr.: V och IX-X.

B. Marratii Wils. $B l$.: VII? Fr.: VII enligt ex., IX enligt förff. Hanbl.: unga, slutna anth:r Stockh. Dalarö Juli 71. Exemplaren hörde dock knappast till denna art.

B. mamillatum Lindb. $B l .:$ VI. Fr.: VII. Hanbl.: anth:r temligen olikgamla från ofärgade, slutna till bruna och tomma Stockh. Juli 70 Honbl.: ett befruktadt ark. Stockh. Juli 70.

B. oeneum Blytt. Bl.: V i slutet och VI. Fr.: VII enligt förff. Enligt exemplar synes den dock fälla locken på vintern samtidigt med lockfällningen hos B. pallens m. fl. Honbl.: just mogen Dovre Juli 72.

B. uliginosum Br. \& Sch. $B l$.: V i slutet och VI i analogi med B pallens. Fr.: (XI) -II. Honbl.: öfvermogna, befruktade ark:r med ännu ofärgade bukar ÖG. 64. Detta exemplar var, för att döma af fruktens utveckling, taget i slutet af Juli.

B. Brownii Br. \& Sch. Bl.: VI. Fr.: (XI)-II enligt ex., ej enl. förff. Hanbl.: slutna eller öppna anth:r Nordl. Bodö 2 Aug. 68. Honbl.: öfvermogna, oftast blott ark:rnas fötter friska Bodö 2 Aug. 68.

B. purpurascens Br. \& Sch. Bl.: V och början af VI. Fr.: (XI) -II. Blr: honblr, ark:r slutna eller ibland något öfvermogna Nordl. 11 Juli 70; samkönade blr, slutna eller tömda anth:r, ark:r från slutna till befruktade Nordl. 19 Juli 70; öfvermogna honblr Nordl. 6 Aug. 70; samkönade blr, anth:r fulla eller tomma, ark:r öppna och något öfvermogna Nordl. Bodö 2 Aug. 68.

B. areticum Br. \& Sch. Bl.: V och början af VI. Fr.: (IX)II. Blr: honblr med öfvermogna ark:r Nordl. 10 Juli 70; honblr temligen gamla, ett ark. dock ännu med ofärgad buk Dovre 14 Aug. 68.

Anm. Endera könets organer felslå ibland hos de 2 sistnämnda arterna, som normalt skulle hafva samkönade blr.

Webera albicans Sch. Bl.: V. Fr.: IV. Hanbl.: ej mogna, anth:r slutna Nordl. 3 Juli 69; just mogna, åtminstone några anth:r opppna Ner. Juni 70 och Nordl. 14 Aug. 69 (ex. från senare stället voro tagna i björkregionen); några anth:r öppna med svärmande antherozoider Ångml. 15 Juni 74; blott ett och annat anth. med något innehåll qvar, dock tusentals svärmande antherozoider 17 Juli 74. Honbl.: snart mogna, ott ark. redan öppet Ner. Juni 70 .

Anm. På ex. från Ångwal. funnos samkönado blr. Honparafyser finnas och äro ofärgade; enligt Bryol. Europ. skulle sådana saknas. 
Webera carnea Sch. $B l .: \mathrm{V}$ ex analogia. Fr.: IV.

W. pulchella Sch. Bl.: V. Fr.: IV. Honbl.: snart mogna, ett ark. redan öppet Ångml. Juni 72; mogna, ark:r slutna eller oppna Ångml. 28 Juni 74.

Anm. Honparafyser egendomliga, en del celler äro mera vidgade, än de andra, och gula.

W. Ludwigii Sch. Bl.: V. Fr.: IV i slutet. Hanbl.: mogna, en del anth:r redan tomma Nordl. 19 Juli 70. Honbl.: öfvermogna, do obefruktade ark:rna med blott fötterna friska, ett befruktadt med ännu ofärgad buk Nordl. 19 Juli 70.

Anm. 16 ark:r räknades $\mathrm{i}$ en blomma.

W. annotina Schwægr. $B l .:(V ?), \mathrm{VI},(\mathrm{VII})$. Fr.: VII enligt talrika exemplar, IV enligt förff. Hanbl.: anth:r ej mogna, slutna Ångml. 15 Juni 74 och 5 Juli 73 ; öppna, ej ännu fullt tömda anth:r Ångml. 18 Juli 74 och Nordl. 20 Aug. 70.

W. Schimperi Sch. Bl.: VI i analogi med följ. Fr.: VI och VII enligt förff.

W. nutans H. Bl.: VI. Fr.: VI, (VII). Blr: just mogna Ångml. Juli 73; öfvermogna honblr med ett befruktadt ark. Nordl. 19 Juli 70; unga fruktskaft, öfver 1 linie långa ÖG. 7 Aug. 70 .

W. cucullata Sch. $B l .: \mathrm{V}$ i analogi med föreg. Fr.: VI, (VII).

W. cruda Sch. Bl.: V. Fr.: VI. Blr: honblr just mogna med oppna ark:r Södml. 20 Juni 68; samkönad bl. med slutna anth:r och blott några ark:r öppna Ångml. 7 Juli 74 (senår!); hanblr öfvermogna, nästan alla anth:r tömda Nordl. 6 Juli 70; hanblr gamla, honblr ark:r med endast fötterna friska ÖG. 4 Aug. 70.

W. longicollis H. Bl.: V. Fr.: VI i slutet och VII. Blr: honblr öfvermogna, ark:r med friska fötter och bukar Dovre Juli 73; uppstickande, linielånga setor synliga Finm. 26 Juli 68.

W. elongata Schwægr. Bl.: V. Fr.: (VI i slutet), VII. Blr: något ofvermogna honblr, ark:rna dock med friska bukar N. Molde 29 Juni 72.

Anm. Hos de 2 sistnämnda arterna synas de paroika anth:rna kunna felslå, så att arterna blifva polygama, likasom W. cruda.

W. polymorpha Sch. Bl.: V, VI. Fr.: VIII, (IX). Blr: anth:r gamla, unga setor uppsticka Dovre Juli 73; honblr öfvermogna, en med ett befruktadt grönt ark., en annan med obefruktade ark:r med friska bukar Nordl. i lafbältet 6 Aug. 70 .

W. acuminata Sch. Bl.: VI, VII. Fr.: VIII, (IX). Honbl.: just mogna Dovre 14 Aug. 68; öfvermogna, en del ark:r med frisk fot och buk Dovre 10 Aug. 58. Höjden öfver hafvet obekant.

Anm. De paroika anth:rna hos W. polymorpha och de knopplika hanblrna hos denna art synas äfven kunna felas.

Leptobryum pyriforme Sch. $B l$.: VI och VII. Fr.: VI och början af VII. Blr: just mogna angml. 22 Juli 74 och 24 Aug. 68; anth:r tomma, de flesta ark:rna öppna ÖG. Juli 69.

A n m. Parafyser trådlika; en del celler ofärgade, andra violetta.

Mielichhofferia nitida Hornsch. Bl.: V, (VI). Fr.: VIII och IX. Hanbl.: just mogna med öppna anth:r S. N. Lomsfjällen 30 Juni 58; gamla anth:r tomma Dorre Aug. 65. 
Anm. Under en blomma visade sig en ett par linier lång nyskottbildning. Hos denna kladokarpa mossa förekommer eljest vanligen ej nyskottbildning under blommorna.

\section{Ordn. Funariaceae.}

Funaria hygrometica Sibth. $B l$.: (VII), VIII och IX, (X). Fr.: VII, (VIII, IX). Hanbl.: ej gamla, nyss tömda anth:r ÖG. 20 Aug. 70; anth:r fulla eller tömda Nordl. 1 Sept. 70; flesta anth:r slutna, alla fulla Ångml. 1 Sept. 74; anth:r under tömning, tusentals svärmande antherozoider Angml. 22 Sept. 74. Honbl.: öfvermogna med befruktade ark:r med ofärgad buk Nordl. 1 Sept. 70 och Angml. 22 Sept. 74 .

Anm. Pà ex. pi Nordl. fans en samkönad blomma.

F. calcarea Wg. Bl.: VII i början. Fr.: på gränsen mellan V och VI. Hanbl.: snart mogna med slutna anth:r Gotl. 24 Juli 31. Honbl.: just öfvermogen Gotl. 24 Juli 31.

Anm. 16 anth:r räknades $i$ en blomma.

F. fascicularis Sch. Bl.: VI i analogi med följ. Fr.: IV och början af $\mathrm{V}$.

F. Ahnfeltii (Fr.) Bl.: VI i början. Fr.: IV och början af V. Hanbl.: just mogna, anth:r slutna eller öppna N. Aalesund 2 Juli 72. Honbl.: mogen, ark:r med friska bukar Aalesund 2 Juli 72.

Physcomitrium pyriforme Brid. Bl.: VI i början. Fr.: VI normalt, (VII). Honbl.: öfvermogna ark:r med friska bukar Uppl. Juli 67.

Pyraridula tetragona Brid. Bl.: VI i analogi med föreg. och följ. Fr.: III i slutet.

Discelium nudum Brid. Bl.: VI. Fr.: III i slutet. Hanbl.: ej mogna, slutna anth:r Ångml. i slutet af Juni 73; just mogna med svärmande antherozoider Angml. $11 \mathrm{Juli} 74$. Honbl.: blr dels med befruktade ark:r, dels med fullformade, som öppnade sig under mikroskopet, Ångml. 11 Juli 72 .

Anm. På ex. från Ångml. Hernösand 11 Juli 72 iakttogs en befruktningsakt. Några han- och honplantor voro preparerade $\mathrm{i}$ vatten för mikroskopet. Preparatet hvimlade af svärmande antherozoider. Ett arkegon, som, då det först kom inom synfältet, var slutet, men visade en tydlig kanal, öppnade sig, under det förf. betraktade detsamma. Alla antherozoider inom synhåll syntes i detsamma dragas till arkegoniets mynning; derefter drogo de sig så småningom ned genom kanalen, tills de kommo till centralblåsan. Denna försattes af antherozoiderna i en starkt vaggande rörelse, tills de slutligen upphörde att svärma och började att absorberas af centralblåsan, hvilken derigenom fick ett papillöst utseende ifrån att förut hafva haft en jemn yta. Jfr Botaniska Notiser, 1875, n:o 2, sidd. 33-34. Anth:rnas antal normalt 8 i hvar blomma.

\section{Ordn. Splachnaceae.}

Splachnum luteum L. Bl.: V och VI. Fr.: V, (VI). Hanbl.: just mogna, anth:r öppna eller slutna Ångml. 25 Juli 73. Honbl.: öfver- 
mogen, ett befruktadt ark. med redan grön buk, ett öfvermoget, obefruktadt och ett ännu slutet Ångml. 17 Juli 74.

Splachnum rubrum L. $B l .: \mathrm{V}$ i slutet och VI. Fr.: V. Hanbl.: slutna eller oppna anth:r Ångml. i slutet af Juni 62 ; just mogna, ett ark. befruktadt, ett par dock ännu slutna Ångml. 25 Juli 73.

S. ampullaceun L. $B l .: \mathrm{V}$ och VI, mest ex analogia. Fr.: V, (VI). Hanbl.: ej mogna, slutna anth:r Ångml. 23 Juli 73.

S. vasculosum L. $B l .: \mathrm{V}$ i slutet och VI. Fr.: V. Honbl.: något ofvermogna Uppl. i slutet af Juli 71; öfvermogna med befruktade ark:r Ångml. 25 Juli 73 och 19 Aug. 74 .

Anm. 4 ark:r räknades i en blomma.

S. sphaericum Sw. Bl.: V. Fr.: V, (VI). Hanbl.: just mogna Nordl. 4 Juli 70. Honbl.: mogna med öppna, friska ark:r Trondhjem 27 Juni 70.

Anm. Ark:rnas antal 4. Hos denna art, likasom hos de öfriga Sphlachnaceae (utom Oedipodium), Amblyodon och Meesia tristicha, förefunnos i blommorna små, parafyslika celltrådar, hvilka oftast voro mycket korta, ibland t. o. m. bestående af blott en cell. Angående dessa jemför Bryol. Europ. vid Amblyodon och Dissodon.

S. Wormskjoldii Horn. $B l_{\text {.: }}(\mathrm{V})$, VI. Fr.: V, (VI). Honbl.: ett ark. befruktadt med hrit buk Lappon. orient. Aug. 72.

Tetraplodon angustatus Sch. Bl.: IV, (V). Fr.: IV. Hanbl.: snart mogna, anth:r slutna Jemtl. 24 Juni 70. Honbl.: snart eller just mogna Jemtl. 24 Juni 70 (litet öfver 1000 fot öfver hafvet); öfvermogna blr med befruktade ark:r med ännu ofärgad buk Helsl. Juni 73.

T. mnioides Sch. $B l$.: V i slutet och VI. Fr.: VI och i början af VII. Hanbl.: ej ännu mogna, slutna anth:r Ångml. 5 Juli 73; åtminstone en del anth:r öppna Ångml. 5 Juli 72. Honbl.: just mogna, ark:r slutna eller öppna. Angml. 5 Juli 72; öfvermogna med befruktade ark:r med gröna bukar Nordl. i videbältet 31 Juli 70.

Tayloria splachnoides Hook. Bl.: VIII och IX i analogi med följ. Fr.: VIII och IX.

T. serrata Br. \& Sch. Bl.: (VII i slutet), VIII och IX. Fr.: VI, VII, (VIII och IX). Hanbl.: flesta blr ännu unga med slutna anth:r, ett anth. dock oppet Ångml. 25 Juli 73; just mogna, anth:r fulla eller tomma Nordl. 17 Aug. 70. Honbl.: något öfvermogna Nordl. 17 Aug. 70; öfvermogna med olikgamla ark:r, dels obefruktade ark:r ej ännu fullformade eller fullformade öppna och friska, dels vackra befruktade med ofärgade bukar Ångml. 21 Sept. 74.

Dissodon Frölichii Grev. Bl.: VI eller VII i analogi med följande. Fr.: VII.

D. splachnoides Grev. $B l$.: V i slutet-VII. Fr.: V, VI, (VII). $B l r$ : honblr ofvermogna, ett ark. befruktadt, de obefruktade med endast fötterna friska Nordl. 17 Juli 70; samkönad blomma, olikgamla könsorganer, alla anth:r ännu slutna, ark:rna från ej fullformade och ofärgade till öfvermogna med vissnad hals, ett t. 0. m. befruktadt med grönaktig buk Nordl. 23 Juli 70; honblr just mogna, ark:r slutna eller oppna Nordl. 6 Aug. 70. 
Anm. Likartad proterogyni synes hos denna art förefinnas med den hos t. ex. Bryum inclinatum iakttagna.

Oedipodium Griffithii Schwægr. Bl.: VIII?. Fr.: VII enligt ex. Endast groddknoppsamlingar, inga könsorganer funnos på ex. från Um. Lapm. i fjällregionen Aug. 55.

\section{Ordn. Schistostega ceae.}

Schistostega osmundacea WM. Bl.: VIII. Fr.: IV. Hanbl.: anth:r ej mogna, slutna Ångml. 3 Aug. 74 och i midten af Aug. 72; just mogna, slutna eller öppna anth:r Ångml. 12 Aug. 74. Honbl.: gamla Ångml. 3 och 12 Aug. 74 och Ryska Karelen Sept. 72.

Anm. 4 eller 6 anth:r i hvar blomma.

\section{Ordn. Grimmiaceae.}

Encalypta streptocarpa H. IV eller V i analogi med do följ. Fr.: VII i slutet och början af VIII.

Anm. På talrika undersökta ex. funnos inga blr.

E. procera Bruch. Bl.: IV, (V). Fr.: VII. Honbl.: just mogna, slutna eller öppna ark:r Nordl. 9 Juli 69; öfvermogna blr, en med ett befruktadt ark. med grön buk Nordl. 19 Juli 70.

E. ciliata Hoffm. $B l$.: IV (-VIII). Fr.: VI och början af VII. Hanbl.: ej mogna, anth:r slutna Sundsvall 12 Maj 74, Östersund 23 Juni 70 och Ångml. 19 Aug. 74. Honbl.: ofvan hanblrna mycket unga (hon-?) blr Sundsvall 12 Maj 74; unga fruktskaft uppsticka, de omgifvande ark:rna gamla Östersund 23 Juni 70 ; ej så gamla, ett ark. befruktadt, de öfriga med åtminstone fötterna friska $N$. Levanger 24 Juni 69 ; ej så gamla, fötter temligen friska Nordl. 6 Juli 70 ; temligen gamla, ett ark. befruktadt, gröngult Nordl. 27 Juli 70; de flesta ark:rna friska, ibland t. o. m. slutna Ångml. 19 Aug. 74 (abnorm tid?).

E. apophysata Nees \& Hornsch. Bl.: IV, (V). Fr.: VII. Hanbl.: snart mogna, anth:r slutna Nordl. i björkregionen 27 Juli 70 . Honbl.: ark:r öfvermogna med friska fötter Nordl. 27 Juli 70.

E. rhabdocarpa Schwægr. Bl.: IV. Fr.: V mest i början. Hanbl.: ej mogna, slutna ark:r VG. 9 Juni 73; tömda anth:r Nordl. 5 och 19 Juli 70. Honbl.: ett befruktadt ark. med redan grön buk VG. 9 Juni 73; dels temligen gamla ark:r, dels unga, fullformade och slutna Nordl. 5 Juli 70; ej så gamla ark:r med friska fötter Nordl. 19 Juli 70.

E. brevicolla Sch. Bl.: IV, (V). Fr.: III enligt ex. från Norrland, VI enligt ex. från Upsala och Um. Lapm. Hanbl.: ej mogna, anth:r slutna Sundsvall 13 Maj 74 och Östersund 24 Maj 70. Honbl.: just mogna, ark:r slutna eller öppna Helsl. Juni 73.

E. spathulata C. Müll. Ej sedd af förf.

E. vulgaris $H$. Bl.: V. Fr.: IV och början af V. Hanbl.: snart mogna, anth:r slutna VG. 2 Juni 73 och Smål. Juli 71 ; just mogna, ett och annat anth. t. 0 . m. tömdt Upsala i slutet af Juni 71. Honbl.: ett ark. fullformadt, men slutet, de öfriga ej fullt utvecklade VG. 2 Juni 73 ; just mogna, ark:r slutna eller öppna Upsala i slutet af Juni 71.

E. commutata Nees \& Hornsch. Bl.: IV, (V) ex analogia. Fr.: VII. 
Orthotrichum Lyellii Hook. Bl.: VI. Fr.: VII. Honbl.: ung (troligen hon-) bl., blott parafyser utvecklade Sk. 16 Juni 71; fullformade, slutna ark:r Göteborg 4 Juli 68; just mogna, öppna och friska ark:r N. Hardanger Juli 73.

O. lejocarpum Br. \& Sch. Bl.: (IV?), V. Fr.: IV. Hanbl.: snart mogna, anth:r slutna N. Molde 5 Juli 72 . Honbl.: ett ark. befruktadt, temligen stort, de öfriga med friska fötter N. Molde 5 Juli 72.

Anm. Hos denna art, likasom hos de flesta följande och hos en del Encalyptae, visar sig en tydlig proterogyni förefinnas, så att de öfre honblrna mogna före de undre hanblrna. Anth:rnas antal 16 i ett par blr.

o. urnigerum Myr. $B l$.: III, IV. Fr.: IV. Honbl.: just mogna Upsala 7 Maj 58; öfvermogna med befruktade, håriga ark:r med ofärgad eller något grönaktig buk Stockh. Juli 72 .

O. diaphanum Schrad. Bl.: III och IV. Fr.: III(-V). Hanbl.: ej mogna, anth:r slutna Göteborg i början af Juni 72. Honbl.: snart mogna, ett par ark:r redan öppna Sk. April 72; blr temligen gamla med endast ark:rnas fötter friska, ett ark. befruktadt med ofärgad buk Göteborg Juni 72 .

O. speciosum N. v. Es. $B l$.: IV-VII. Fr.: V i slutet-början af VII. Hanbl.: ej mogna, anth:r slutna Upsala Maj 69, ÖG. 18 Juli 70, Mdpd 21 Juli 74 och Nordl. 20 Aug. 70. Honbl.: ett par ark:r redan fullformade, men slutna Upsala Maj 69; snart eller just mogna blr, alltid åtminstone några ark:r öppna ÖG. 18 Juli 70, Nordl. Juli 69 och 21 Aug. 70; olikgamla ark:r, från fullformade slutna till ett befruktadt med hvitgrön buk Mdpd 21 Juli 74.

O. rupestre Schleich. Bl.: III-VI. Fr.: V normalt. Hanbl.: ej mogna, anth:r slutna Ångml. 29 Juni 74, Upsala Juli 71 och Nordl. 14 Aug. 70. Honbl.: befruktade ark:r med hvita bukar, de öfriga något öfvermogna Upsala Maj 70 och Ångml. 19 Aug. 74; befruktade ark:r med grön buk, de obefruktade med friska bukar VG. 1 Juni 70 och Nordl. 14 Aug. 74; just mogen bl. Ångml. 29 Juni 74; en bl. ej mogen med fullformade, slutna ark:r, dernedom en bl. med ett befruktadt ark. med grōn och hårig buk Upsala Juli 71 .

0. affine Schrad. Bl.: IV, (V). Fr.: (V i slutet)-VII. Hanbl.: ej mogna, anth:r slutna Berlin Juni 28 och Stockh. 17 Juli 71. Honbl.: nảgot öfvermogna, befruktade ark:r med ofärgad buk Hall. 3 Juni 72, VG. 4 och 6 Juni 73 och Stockh. 17 Juli 71 ; ett stort, befruktadt ark. med grōn och hårig buk Öl. 27 Juli 67.

Anm. 8 ark:r räknades i flera blr.

O. fastigiatum Bruch. Bl.: III-V. Fr.: (IV), V. Hanbl: ej mogna, anth:r slutna Upsala April 74, ÖG. 25 Juni 69 och Öl. 18 Juli 67. Honbl.: snart mogna blr med ett par ark:r redan öppna Upsala 6 April och i slutet af April 74; just mogna blr Göteborg 4 Juli 68; en blomma just mogen, dernedom en bl. med ett befruktadt ark. med grōn och hårig buk Skōfde 2 Juni 73; blr dels med befruktade, håriga ark:r, dels i samma blr stundom t. 0. m. ofärgade, slutna ark:r VG. 4 Juni 73 och Juni 72 samt Stockh. Juli 72 ; just ofvermogen med ett befruktadt ark. med hvit buk ÖG. 25 Juni 69. 
Orthotrichum tenellum Bruch. $B l .:$ (III), IV. Fr.: IV-början af V. Hanbl.: några anth:r fullt tömda England Maj 68. Honbl.: öfvermogen med ett befruktadt ark. med hvit buk England Maj 68.

O. patens Bruch. Ej undersökt och är dessutom enligt Prof. Lindberg ej säkert medborgare af Skandinaviens flora.

O. alpestre Hornsch. Bl.: V-(VII). Fr.: VI, (VII). Hanbl.: tomma anth:r Nordl. 27 Juli 70; unga eller snart mogna blr Um. Lapm. Aug. 65 och Lappon. orient. Aug. 72. Honbl.: något öfvermogna Nordl. 21 Juli 69; ett befruktadt ark. med grön, hårig buk Nordl. 27 Juli 70; fullformade, slutna ark:r Um. Lapm. Aug. 65. Höjden öfver hafvet på sista lokalen obekant.

O. stramineum Hornsch. Bl.: (III), IV, (V). Fr.: V-(VII). Honbl.: en bl. med ett befruktadt ark. med ofärgad buk, en med ett befruktadt med gulgrön buk, en med vissnade ark:r utom fötterna, som hos ett par ark:r voro friska VG. 6 Juni 74; just mogen Ångml. 8 Juli 72; befruktade eller gamla ark:r Ångml. 8 Juli 73; uppstickande, linielånga fruktskaft Nordl. 12 Aug. 69.

O. Hogeri Brid. Bl.: IV ex analogia. Fr.: V och VI enligt förff.

O. Sehimperi Hamm. Bl.: IV. Fr.: V i slutet, VI. Honbl.: en bl. just mogen, en annan med ett befruktadt, gröngult ark. Sachsen Maj 72.

0. pumilum Sw. $B l$. : IV?, V, (början af VI). $F r .:$ V i slutet, VI. Hanbl.: just mogna eller nästan tomma anth:r Stockh. 17 Juli 71. Honbl.: ark:r dels friska, öppna eller slutna, dels befruktade med hvit eller hvitgrön buk Stockh. 17 Juli 71.

Anm. Bland löfmossorna äro anth:rna längst skaftade hos Orthotricha och hos Timmiae. Hos de förra är skaftets eller fotens längd ofta lika med halfva antheridiets. Hos de senare är längden lika stor, men äro dessutom hos Timmiae fötterna ovanligt tjocka, t. 0 . m. jemntjocka med antheridiet.

O. obtusifolium Schrad. Bl.: (II)-IV-(VII). Fr.: IV. Hanbl.: blr temligen olikgamla, anth:rna $\mathrm{i}$ några snart eller just mogna, $\mathrm{i}$ andra tomma Ångml. 1 Juni 70 och 29 Juni 74. Honbl.: just mogna, ark:r slutna eller öppna Upsala 9 Mars 74 och Ångml. 1 Juni 70; ark:r vissnade med friska fötter eller befruktade med gröna bukar Upsala Juli i slutet 71 ; blr af olika ålder, $i$ en ett ark. befruktadt med hvit buk ch ett ofärgadt och slutet, i andra blr började deremot fruktskaften uppsticka Ångml. Aug. i slutet 72 .

O. cupulatum Hoffm. Bl.: III, IV. Fr.: V. Hanbl.: mycket unga Gotl. Juni 66. Honbl.: befruktade ark:r med grön, hårig buk, de ej befruktade med friska fötter ech bukar Gotl. Juni 65 .

Anm. 2 befruktade ark:r funnos i samma blomma.

0. Sturmii Hornsch. Bi.: IV i slutet, V (-IX). Fr.: V. Hanbl.: ej mogna, anth:r slutna Östersund 23 Juni 70 och Ner. Sept. 68. Honbl.: just mogna, ark:r slutna eller öppna Östersund 23 Juni 70; blr af ganska olika ålder, ett ark. ännu ofärgadt, slutet, andra med bukarne eller blott fötterna friska, ett befruktadt med hvitgrön buk Stockh. Juli 70; just öfvermogna med friska ark:r Ner. Sept. 68 (abnorm blomningstid l). 
Orthotrichum gymnostomum Bruch. Bl.: III, IV. Fr.: III. Hanbl.: ej mogna blr med slutna anth:r, dernedom gamla blr Södml. 20 Juni 68. Honbl.: öfvermogna blr, befruktade ark:r med hvit eller grön buk, de andra med blott fötterna friska Södml. Maj 69; något öfvermogna med obefruktade, friska och öppna ark:r och ett befruktadt med hvit buk Södml. 20 Juni 68.

0. pulchellum Sm. $B l$.: III eller IV ex analogia, VI eller VII enl. ex. Fr.: IV. Honbl.: ej så gammal blomma, ett ark. befruktadt med grön buk, de obefruktade med friska fötter och bukar Sk. 12 Sept. 73.

Anm. 4 ark:r räknades i en blomma.

O. macroblephare Sch. Bl.: III i slutet-V ex analogia. Fr.: IV.

O. Killiasii C. Müll. Bl.: III, IV. Fr.: IV. Hanbl.: mogna, anth:r ej tömda Dovre 27 Juni 70. Honbl.: öfvermogna, ett ark. befruktadt med gulgrön buk, de öfriga temligen vissnade, ett dock med frisk buk Dovre 27 Juni 70.

O. Sommerfeltii Sch. Bl.: III och IV. Fr.:-IV. Hanbl.: ej mogna, anth:r slutna Nordl. 17 Juli 69. Honbl.: blr af temligen olika ålder, ark:r från öppna med friska bukar till befruktade med hårig, grön buk Nordl. 17 Juli 69.

O. arcticum Sch. $B l$.: III, (IV). Fr.: IV. Honbl.: öfvermogna, befruktade ark:r med gulgrön eller ofärgad buk, ej befruktade ofta ännu med friska bukar Nordl. 5 Juli 69 .

Anm. I samma blomma funnos 2 befruktade ark:r.

0. Blyttii Sch. Bl.: III (-VII). Fr.: IV. Hanbl.: snart mogna, ett anth. t. 0. m. öppet Nordl. 17 Juli 70; dels något öfvermogna blr med knappt sluttömda anth:r, dels snart mogna blr Nordl. 13 Aug. 70. Honbl.: ett ark. befruktadt med grön buk, de obefruktade med friska bukar Nordl. 17 Juli 70; dels öfvermogna blr med befruktade ark:r, synliga för det obeväpnade ögat, och obefruktade med friska bukar, dels just mogna blr Nordl. 13 Aug. 70.

Anm. De mogna blrna af den 13 Aug. 70 synas vara utvecklade på abnorm tid. Samma ex. visade äfven ett undantag från den på sid. 7 angifna regeln, att under samma år först en han-axelutveckling och sedan en hon-axelutveckling eger rum. Ofvan de befruktade honblrna förefunnos nemligen först hanblr och sedan honblr.

O. laevigatum Zett. $B l$.: III och IV ex analogia. Fr.: (IV) och början af V.

O. anomalum H. Bl.: (III)-VI. Hanbl.: ej mogna, anth:r slutna Trondhjem 26 Juni 69, Stockh. 17 Juli 70 och Mdpd 21 Juli 74. Honbl.: just mogna Stockh. 11 Maj 68 och 17 Juli 71; fullformade, slutna anth:r Trondhjem 26 Juni 69; öfvermogna, ett ark. befruktadt med gulgrön buk Mdpd 21 Juli 69.

Ulota Hutchinsiae Sch. Bl.: V i slutet och VI. Fr.: VI. Hanbl.: ej mogna, slutna anth:r Gefle Juli 68 och Nordl. 2 Sept. 70; en del blr med anth:r tomma, andra med unga och slutna Nordl. Juli 70. Honbl.: just mogna, ark:r slutna eller öppna Ångml. 8 Juli 73. 
Ulota curvifolia Brid. Bl.: V, (VI). Fr.: VI. Hanbl.: just mogna med slutna eller öppna anth:r Ångml. 8 Juli 73. Honbl.: ark:r något öfvermogna, dock helt friska Ångml. 8 Juli 73 ; just mogna, slutna eller öppna ark:r Ångml. 4 Juli 72; befruktade ark:r med grön buk Nordl. Juli i början 70 .

U. Bruchii Hornsch. Bl.: VIII och IX. Fr.: VIII och IX. Hanbl.: tomma anth:r VG. 1 Juni $73 ; 2$ blr gamla med tomma anth:r, 2 unga med slutna Nordl. 22 Juli 70 ; ej mogna, anth:r slutna Nordl. 15 Aug. 70; anth:r slutna eller öppna, friska Trondhj:s st. 12 Sept. 70; de flesta anth:rna tömda, endast ett par ännu slutna Örebro Okt. 72. Honbl.: öfvermogna blr, de befruktade ark:rna med gröna, håriga bukar, de ej befruktade med friska fötter och ett med äfven buken frisk VG. 1 Juni 73; gamla blr, i en dock ark:r med friska fötter Nordl. 22 Juli 70; endast fötterna friska Nordl. 15 Aug. 70; ett stort, befruktadt ark. med gulgrön buk Trondhj:s st 12 Sept. 70; öfvermogna blr, ej befruktado ark:r med friska bukar, ett befruktadt med hvit buk med små håranlag Örebro Okt. 72.

U. crispa Brid. Bl.: VIII och IX. Fr.: VIII och IX. Hanbl.: just mogna, en del anth:r öppna Jönköping 5 Okt. 69; tömda anth:r Örebro Okt. 72. Honbl.: ark:r fullformade och friska, öppna eller slutna Jönkōping 5 Okt. 69; befruktade ark:r med ofärgad, hvit buk Örebro Okt. 72.

U. crispula Bruch. $B l$.: IV liktidigt med lockfällningen, likt Ortotricha. Fr.: IV.

U. Ludwigii Brid. Bl.: IV (eller V). Fr.: VIII och IX. Hanbl.: ofvermogna, dock tydligen årets N. Hardanger Juli 73. Honbl.: ofvermogna, ett ark. befruktadt med hvit buk, de andra vissnade med endast fötterna temligen friska Hardanger Juli 73.

U. Drummondii Brid. Bl.: IV (eller V). Fr.: VIII och IX. Honbl.: något öfvermogna, ett ark. befruktadt med hvit buk, de andra med friska fötter Nordl. 11 Juli 70; linielånga, uppstickande fruktskaft Nordl. 15 Aug. 70.

U. phyllantha Brid. Blr ej funna af förf. Frukt ej känd.

Zygodon viridissimus Brid. Bl.: VI. Fr.: IV. Honbl.: gamla med vissnade ark:r VG. 8 Juni 73 ; just mogen, ark:r slutna eller öppna Sk. Juli 60.

Amphoridium lapponicum Sch. $B l$. : V i slutet och VI i början. Fr.: IV. Hanbl.: ej mogna, anth:r slutna Trondhjem 28 Juni 70; just mogna Dovre Juli 73. Honbl.: snart mogna med fullformade, oftast slutna ark:r Trondhjem 28 Juni 70 och Dovre Juli 74.

A. Mougeottii Sch. Bl.: VIII. Fr.: VI enligt förff. Honbl.: just mogna, ark:r slutna eller öppna ÖG. omkring 1 Sept. 70. På talrika ex. från andra tider af året funnos inga blr.

Plychomitrium poly, íyllum Fürnr. Bl.: VI. Fr.: III. Hanbl.: snart mogna, anth:r slutna Bergens st. Juli 73. Honbl.: med àtminstone några fullformade ark:r Bergens st. Juli 73.

Cuscinodon pulvinatus Spreng. Bl.: VIII?. Fr.: III och IV, mest i analogi med Grimmiae. Honbl.: ett befruktadt, temligen långt ark. 
med grön bak N. Lomsfjällen 30 Juni 58; ofvan gamla blr en just mogen N. Gudbrandsdalen Aug. 73.

Hedwigia ciliata $H . \quad B l$ : på gränsen mellan $V$ och VI. Fr.: III. Hanbl.: ej mogna, anth:r slutna Boh. Juni 70, Angml. 10 Juni och 7 Juli 74. Honbl.: snart eller just mogna blr, ark:r slutna eller öppna N. Levanger 24 Juni 69 ; ej mogna, endast ett ark. fullformadt Ångml. 7 Juli 74 (senår).

Hedwigidium imberbe Br. \& Sch. Bl.: V eller VI i analogi med föreg. Fr.: III enligt förff.

Grimmia maritima Turn. $B l$.: på gränsen mellan V och VI. Fr.: på gränsen mellan III och IV. Honbl.: just mogna, de flesta ark:rna öppna N. Levanger 24 Juni 69.

G. apocarpa H. Bl. och Fr.: liktidiga med föreg:s. Hanbl.: just mogna med fulla eller tomma anth:r Angml. $8 \mathrm{Juli} 73$. Honbl.: just mogna med slutna eller öppna arłs:r Ångml. 8 Juli 73.

G. conferta Funck. Bl.: liktidig med föreg:s ex analogia. Fr.: på gränsen mellan III och IV.

G. anodon Br. \& Sch. Bl.: IV i analogi med följ. Fr.: IV. Blr: mycket unga (han- eller hon-?) blr med blott parafyser Wien 20 April 67.

G. pulvinata Sm. Bl.: IV. Fr.: (III), IV, (V). Honbl.: dels just mogna med öppna, friska ark:r, dels öfvermogna med blott fötterna eller ibland äfven bukarne friska VG. 1 Juni 73; öIvermogna, ark:r med friska bukar och fötter $V G$. i början af Juni 72; öfvermogna, ark:r vissnade, ett dock ännu med ofärgad buk ÖG. 1 Juli 68 .

G. apiculata Hornsch. Bl.: IV ex analogia. Fr.: III i slutet och IV i början, mest ex analogia.

G. Schultzii Wils. Bl.: IV $\left.\right|_{\text {ex }}$ analogia. Fr.: III i slutet och IV i början.

G. elatior Br. \& Sch. Bl.: IV. Fr.: III i slutet och IV i början. Honbl.: dels gamla, dels just öfvermogna, de senare med ark:rnas fötter och bukar ännu friska Christiania 15 Juni 58; temligen gamla, fötterna annu friska ÖG. Juni 55; öfvermogna med stora, befruktade ark:r Ångml. i slutet af Juli 72 .

G. Mühlenbeckii Sch. Bl.: III. Fr.: III i slutet (-V). Hanbl.: just mogna, anth:r fulla eller tomma Ångml. 2 Juni 70. Honbl.: just öfvermogna med oppna, friska ark:r Sundsvall 12 Maj 74; dels gamla blr, dels en temligen frisk med ett ark. med frisk buk Angml. 1 Juni 70; ofvermogna, ark:r med endast fötterna friska Ångml. 16 Juni 74, ÖG. 1 Aug. 71 och Upsala 1 Okt. 66; gamla Ångml. 5 Juli 72; gröna, fullformade frukter Ångml. 0kt. 74 .

G. spiralis Hook. Bl.: III eller IV. Fr.: på gränsen mellan III och IV. Honbl.: temligen gamla, fötter dock ännu temligen friska S. N. Lom 7 Juli 58.

G. Hartmanii Sch. Bl.: IV. Frukt ejkänd. Honbl.: just mogna, ark:r slutna eller ôppna Sk. 25 Maj 70.

G. torquata Grev. Blr ej funna af förf. Frukt $\theta j$ känd.

G. contorta Sch. Bl.: III eller IV, mest ex analogia. Fr.: III eller IV, mest ex analogia. Honbl.: gamla Skottland Juli 71 och Tyrolen Aug. 67. 
Grimmia Donnii Sm. Bl.: V, (VI). Fr.: på gränsen mellan III och IV. Hanbl.: just mogna, fulla eller tomma anth:r Nordl. 6 Juli 70; gamla Nordl. Aug. 69. Honbl.: föga öfvermogen, ett ark. befruktadt knappt större än de ej befruktade, af de senare ett ännu färglöst Nordl. 4 Juli 69 ; en bl. med ett befruktadt, gulgrönt ark., en annan just mogen Nordl. 6 Juli 70; flera blr med hvar sitt befruktade, temligen starkt utvecklade ark. Nordl. Aug. 69 och 3 Sept. 70.

G. ovata WM. Bl.: III eller på gränsen mellan V och VI. Fr.: på gränsen mellan III och IV. Hanbl.: snart mogna anth:r Nordl. 10 Juli 70. Honbl.: befruktade, stora ark:r med gröngula bukar Gefle April 70; ej så mycket öfvermogna blr, ett ark. befruktadt med ofärgad buk, de ej befruktade ej så mycket vissnade, ofta med ännu friska och ofärgade bukar Ångml. 1 Juni 70; just öfvermogna, ark:r med friska, ofärgade bukar och bruna halsar Ångml. 29 Juni 74; dels gröna, fullformade frukter, dels en bl. med ett befruktadt ark., som ej stack ofvan perichetiet och hade grön buk Ångml. 26 Juli 72; 2 blr öfvermogna, ark:r med friska bukar och fötter, ett t. o. m. ännu ofärgadt och slutet, en annan bl. med ett mycket långt befruktadt ark. Nordl. 20 Juli 70.

G. elongata Kaulf. Bl.: III eller IV. Fr.: på gränsen mellan III och IV. Honbl.: gamla Dovre Juli och Aug. 73; mycket förvissnade, ark:rna:s ofärgade och friska fötter visade dock, att de tillhörde årets blr Dovre 9 Aug. 58.

G. leucophaea Grev, Bl.: på gränsen mellan V och VI. Fr.: på gränsen mellan III och IV. Honbl.: något öfvermogna, ark:r dock med friska bukar och fötter Upsala i midten af Juli 71. På talrika ex. tagna före midten af Juni funnos inga årsblr.

G. commutata Hüb. $B l .:$ IV, (V). Fr.: IV. Honbl.: dels gamla, dels unga, de senare med blott parafyser utvecklade Upsala Juni 71; öfvermogna, ett ark. befruktadt, de ej befruktade med temligen friska bukar VG. 10 Juni 73; öfvermogna, ett ark. gulgrönt, befruktadt, de öfriga med friska fötter Stockh. i slutet af Juni 71; ej så gamla, ark:r med fötter och nedre delar af bukarne friska, ett t. 0 . m. ej annu öppnadt Upsala Juli 71.

G. montana Br. \& Sch. Bl.: IV, (-VI). Fr.: IV. Honbl.: snart eller just mogna blr med slutna eller öppna ark:r Stockh. 2 Juni 64 (en något sen vår!); just mogen blomma, slutna eller öppna ark:r Stockh. Juli (rätt tid?) 72.

G. alpestris Schleich. $B l$ : IV ex analogia. Fr.: III eller IV ex analogia.

G. unicolor Grev. Bl.: III. Fr.: IV. Hanbl.: just mogna Sundsvall 13 Maj 74; tömda Christiania 19 Juni 58. Honbl.: öfvermogna, ark:r med ännu temligen friska bukar, ett befruktadt Christiania 19 Juni 58 .

G. atrata Mielichh. Bl.: IV. Fr.: III oeh IV ex analogia; frukt dock ej funnen i Skand. Honbl.: vissnade arksr, fötterna dock ānnu friska Dovre Aug. 65. 
Grimmia mollis Br. \& Sch. Bl.: III eller IV. Fr.: IV. Honbl.: öfvermogna, ett ark. befruktadt, de obefruktade med ännu friska fötter Torn. Lpm. Juli 52.

Racomitrium patens Hüb. och Sch. Syn. Bl.: IV. Fr.: på gränsen mellan III och IV. Honbl.: öfvermogna, ett ark. befruktadt med nedtill ofärgad, upptill gulgrön buk, de ej befruktade oftast med blott fötterna friska Nordl. 2 Juli 70; vissnade ark:r Ångml. 8 Juli 73.

R. ellipticum Br. \& Sch. Bl.: IV?, V. Fr.: på gränsen mellan III och IV. Honbl.: öfvermogna, ark:r med friska, ofärgade bukar N. Aalesund 2 Juli 72.

R. protensum Al. Br. Bl.: IV ex analogia, VI enligt ex. Fr.: IV. Honbl.: fullformade, slutna ark:r Göteborg 4 Juli 68.

Anm. Honparafyserna hos denna art och hos R. heterostichum äro serdeles vackra och perlsnörlika derigenom, att cellerna äro nästan klotrunda. Eljest äro parafyserna hos Grimmiae och Racomitria serdeles svagt utvecklade och ofärgade. Ofta kunna de t. o. m. helt och hållet felas. Hos Orthotricha förefinnas deremot i hanblrna vackra, gula parafyser, i honblrna ofärgade.

R. aciculare Brid. Bl.: IV. Fr.: IV. Honbl.: just mogna ark:r Ångml. 7 Juni 74; öfvermogna, befruktade ark:r ännu nästan ofärgade VG. 2 Juni 73 och Sk. 11 Juni 73.

R. sudeticum Br. \& Sch. Bl.: IV. Fr.: III i slutet. Honbl.: fullformade, slutna ark:r Ångml. 1 Juni 70; öfvermogen, ett ark. befruktadt, de öfriga med friska fötter och bukar Ångml. 5 Juli 73.

R. microcarpum Brid. Bl.: IV. Fr.: III i slutet (-VII). Honbl.: ej gamla ark:r med friska fötter och bukar, vissnade halsar Nordl. 6 Juli 70.

R. heterostichum Brid. Bl.: IV. Fr.: på gränsen mellan III och IV. Honbl.: just mogna, flesta ark:r öppna Boh. Juni 70; öfvermogna, ark:r af olika ålder, dels befruktade hvitgröna, dels t. 0 . m. ej ännu fullformade Trondhjem 27 Juni 70; ark:r med fötterna och nedre delarne af bukarne friska Nordl. 4 Juli 70 .

Anm. 8 ark:r räknades i en blomma.

R. canescens Brid. Bl.: (III), IV. Fr.: IV. Hanbl.: ej mogna, anth:r slutna Ångml. 19 Aug. 73 (utvecklade på abnorm tid!). Honbl.: just mogna blr, alla ark:r öppna Ångml. 1 Juni 70; något öfvermogen, ark:r öppna, ett dock ännu slutet Nordl. 12 Juli 69; uppstickande, linielånga, befruktade ark:r, de obefruktade med friska fötter Ångml. 19 Aug. 73.

R. lanuginosum Brid. $B l$ : (VI i slutet) och början af VII. Fr.: (IV i slutet), V. Honbl.: unga (hon-?) blr med blott parafyser tydliga ÖG. 1 Juli 68; öfvermogna, ark:r med ännu friska bukar ÖG. 19 Aug. 70.

R. fasciculare Brid. Bl.: (VI i slutet) och VII i början. Fr.: IV i slutet, V. Hanbl.: mogna, anth:r fulla, slutna eller öppna Ångml. 20 Juli 74. Honbl.: unga blr, blott parafyser utvecklade Angml. 12 Juni 74 och 5 Juli 72; just mogna, ark:r slutna eller öppna Ner. Juli 55; något öfvermogna, ark:r med friska, ofärgade bukar och öppna, bruna halsar Ångml. 3 Aug. 74 . 
Cinclidotus fontinaloides PB. Bl.: VI. Fr.: V. Honbl.: snart mogna, ett ark. öppet, de öfriga slutna ÖG. 1 Juli 73.

\section{Ordn. Pottiaceae.}

Tortula princeps Not. $B l$. : på gränsen mellan VI och VII i analogi med följ. Fr.: V i slutet, VI.

T. ruralis Ehrh. Bl.: på gränsen mellan VI och VII. Fr.: V i slutet, VI. Honbl.: just mogna, ark:r slutna eller öppna Sk. Juli 68 och ÖG. 24 Juli 70.

Anm. Pa ex. från Sk. fans afven en samkönad blomma.

T. intermedia Wils. $B l$.: ex analogia liktidig med föreg:s. $F r$ : V i slutet, VI. Blr: ännu endast parafyser utvecklade Öl. 27 Juni 67.

T. papillosa Wils. Blr ej funna af förf. Frukt ej känd.

T. latifolia Hn. Bl.: VI. Fr.: V enligt de flesta förff.; frukt dock ej funnen i Sverige. Honbl.: något öfvermogna, ark:r med halsarne stundom något vissnade Sk. 23 Juli 71.

Anm. 16 ark:r räknades i en blomma.

T. norvegica Wg. Bl.: VI. Fr.: VI ex analogia och enligt förff.; frukt dock ej funnen i Skand. Honbl.: något öfvermogna, ark:r med fotter och nedre delar af bukarne friska Nordl. i granbältet 24 Juli 70.

T. laevipila Schwægr. Bl.: VI i slutet och VII i början ex analogia. Fr.: V i slutet och VI.

T. alpina Wils. Bl.: VIII. Fr.: VIII-X, mest enligt förff.; frukt dock ej funnen i Sverige. Honbl.: öfvermogna, friska och öppna ark:r Tyrolen Sept. 67.

Anm. Halsen var hos de öppna ark:rna spiralvriden. Detta förhållande synes ej vara så vanligt hos löfmossorna, som Janczewsky i sin uppsats: "Ueber Entwickelung der Archegoniens, Bot. Zeit. 1872 n:o 21, synes antaga. Utom hos ofvannämnda art har förf. dock sett sådana spiralvridna halsar hos Tortula latifolia, Desmatodon obliquus och Dicranum hyperboreum.

T. subulata H. Bl.: VII i slutet och VIII i början. Fr.: VI och i början af VII. Hanbl.: ej mogna, anth:r slutna Sk. Aug. 68.

T. mucronifolia Schwægr. Bl. och Fr.: liktidiga med föreg:s. Hanbl.: just mogna, anth:r fulla, slutna eller öppna N. Gudbrandsdalen 19 Aug. 68. Honbl.: mogna, alla ark:r öppna och friska N. Gudbrandsdalen 19 Aug. 68 .

T. squarrosa Not. Bl.: VII eller VIII? Fr.: IV eller V, mest enligt förff.; frukt dock ej funnen i Sverige. Honbl.: ännu tydligen årets, dock mycket vissnade ark:r Bonn Nov. 70.

T. tortuosa Ehrh. Bl.: VI i slutet, (VII i början). Fr.: VI. Honbl.: åtminstone några ark:r fullformade Dorre Juli 73; just mogna, slutna eller öppna ark:r Nordl. 25 Juli 70.

$A \mathrm{~nm}$. T. inclinata torde vara liktidig med föregående, såsom varande blott en form af densamma enligt Prof. Lindberg.

T. fragilis Wils. $B l$. och $F r .:$ liktidiga med föreg:s, mest ex anal. Honbl.: gamla Sk. 12 Aug. 71. 
T. cylindrica Lindb. $B l .: \mathrm{V}$. Fr.: $\mathrm{V}$, mest enligt förff.; frukt dock ej funnen i Sverige. Honbl.: öfvermogen, ark:r med friska fötter Sk. Juli 72 .

T: fallax Schrad. Bl.: V. Fr.: I-(III). Hanbl.: ej mogna, anth:r slutna Smål. 1 Maj 72. Honbl.: snart mogna, ark:r fullformade, men slutna VG. 2 Juni 73; öfvermogna Nordl. 17 Juli 70.

T. recurvifolia Berk. Bl.: $V$ ex analogia. Fr.: I-(III) ex anal.

T. unguiculata Roth. Bl.: V. Fr.: I, II. Honbl.: unga, endast parafyser utvecklade Ner. 11 Maj 73; just mogna, mycket vackra Trondhjem 28 Juni 69.

T. angustata Wils. Ej sedd af förf.

T. icmadophila (Sch.) Lindb. Bl.: VI. Fr.: VIII och IX enligt förff.; frukt dock ej funnen i Skand. Honbl.: öfvermogna, endast fötterna friska Dovre Aug. 65.

T. Hornschuchii Not. $B l .:$ V. Fr.: IV eller V enligt förff. Honbl.: offvermogna med endast fötterna friska Stockh. Juli 52.

T. revoluta Schrad. $B l$.: V eller VI ex analogia. Fr.: IV eller V enligt förff., VI i analogi med följ.

T. convoluta Schrad. Bl.: VI. Fr.: VI. Honbl.: just mogna, ark:r slatna eller oppna Mdpd 21 Juli 74.

T. muralis H. Bl.: (IV), V. Fr.: (V i slutet), VI, (VII). Hanbl.: gamla Smål. 21 Maj 72. Honbl.: olikgamla ark:r, ett vissnadt och brunt, ett friskt, ofärgadt och opppet och ett ännu slutet Smål. 21 Maj 72 ; just mogna Skottland Juni 73; mycket vissnade blr, knappt synbart årets Sk. 6 Juli 71; öfvermogna och vissnade årsblr Mdpd 21 Juli 74.

T. aloides Ångstr. $B l$.: IV i slutet och V i början. Fr.: (XI-) I, II. Hanbl.: flesta anth:r tomda Gotl. Juni 65. Honbl.: ett ark. befraktadt, de öfriga något vissnade Gotl. Juni 65 .

Anm. 16 anth:r räknades i en blomma.

T. ambigua Ångstr. $B l$.: IV i slutet och V i början i analogi med föreg. Fr.: (XI-) I, II.

T. stellata Lindb. $B l$.: IV i slutet och $\mathrm{V}$ i början i analogi med föreg. Fr.: I, II.

T. brevirostris Hook \& Grev. Bl.: IV?, V. Fr.: I-(III). Blr: ark:r just mogna och öppna Christiania 19 Juni 70; frukter unga, redan fullformade S. N. Eidsvold 24 Juli 72.

Desmatodon Laureri Br. \& Sch. Bl.: VII. Fr.: VI i slutet och VII. Hanbl.: unga, dock åtminstone ett par anth:r fullformade Dovro Juli 73.

D. obliquus Br. \& Sch. Bl.: VI. Fr.: VII. Honbl.: just mogna, ark:r slutna eller öppna Dovre Juli 73.

Anm. Ark:rnas antal i en blomma 6.

D. cernuus Br. \& Sch. Bl.: VI eller VII ex analogia. Fr.: VII, (VIII).

D. latifolius Brid. Bl.: VI. Fr.: VI. Hanbl.: ej mogna, ark:r slutna Nordl. i lafbältet 23 Juli 70. Honbl.: öfvermogna Nordl. 12 Ang. 69 .

D. systylius Br. \& Sch. Bl.: VI. Fr.: VI. Hanbl.: anth:r nyss tőmda Dovre 7 Aug. 59. Honbl: ett ark. befruktadt med ofärgad buk Dovre 7 Aug. 58. 
Trichostomum tophaceum Brid. Bl.: V. Fr.: I, II, (III?). Honbl.: åtminstone en del ark:r fullformade Sk. Juni 61 .

T. rigidulum Sm. Bl.: V. Fr.: I, II, (III). Honbl.: just mogna, ark:r slutna eller oppna VG. 8 Juni 73.

T. mutabile Bruch. $B l .:$ V. Fr.: III eller IV enligt förff., frukt dock ej funnen i Sverige. Honbl.: ark:r fullformade, friska Gotl. 4 Juni 60 ; öfvermogna ark:r med temligen friska fötter Gotl. Juni? 65.

T. erispulum Bruch. Bl.: VI. Fr.: VI. Hanbl.: anth:r snart mogna, slutna Upsala 7 Juli 50. Honbl.: mogna, slutna eller öppna ark:r Upsala 7 Juli 50.

'T. flavovireus Bruch. Bl.: ej undersökt. Fr.: IV eller V enligt förff.; frukt dock ej funnen i Sverige.

Leptotrichum glaucescens Hampe. Bl.: V i Nordl., VII i Ångml. Fr.: VI. Hanbl.: anth:r ej mogna, slutna Ångml. 14 Juli 68 . Honbl.: öfvermogna, ark:r med fötterna och ibland äfven bukarne friska Nordl. i början af Juli 69; öfvermogna, befruktade ark:r med gröna bukar, de andra med blott fötterna friska Nordl. 27 Juli 70; mogna, ark:r slutna eller öppna Ångml. 3 Aug. 73.

L. pallidum Hampe. Bl.: VII ex analogia. Fr.: IV enligt förff. Honbl.: 2-3 linier långa, uppstickande fruktskaft Tyskland Heidelberg Juli 42.

L. flexicaule Hampe. Bl.: III, (IV). Fr.: VI. Hanbl.: anth:r tömda Östersund Maj 70, Stockh. 13 Maj 68 och Ångml. 8 Juni 69; anth:r fullformade, slutna Ner. 21 Nov. 72. Honbl.: ark:r fullformade, slutna Stockh. 13 Maj 68; mogna, flesta ark:r öppna Östersund Maj 70.

L. zonatum Funck. Ej sedd af förf.

L. homomallum Sch. $B l$.: VII. Fr.: III. Hanbl.: snart mogna, anth:r slutna Nordl. 20 Aug. 70. Honbl.: 1 till 2 linier lănga, uppstickande fruktskaft Ner. 6 April 73 och Angml. 8 Juni 69; öfvermogna blr med befruktade ark:r Nordl. 20 Aug. 70.

L. tortile Hampe $\beta$ pusillum. Bl.: V. Fr.: (XI-) I, II. Hanbl.: anth:r snart mogna, slutna Lul. Lapm. 5 Juli 67. Honbl.: endast få ark:r fullformade Ångml. 15 Juni 74; mogna, ark:r slutna eller öppna Lul. Lapm. 5 Juli 67.

Trichodon cylindricus Sch. $B l .: \mathrm{V}$ i slutet och VI i början. Fr.: V. Honbl.: åtminstone några ark:r fullformade Ångml. 4 Juli 74; ark:r af temligen olika ålder från fullformade slutna till öppna och något vissnade Ångml. Juli 72.

Anm. Ark:rnas antal i en blomma 8.

Ceratodon purpureus Brid. $B l .:$ V i slutet och VI i början. Fr.: V. Hanbl.: flesta anth:r tömda, ett dock ännu ej fullt tömdt ÖG. 21 Aug. 72. Honbl.: något öfvermogna, ett ark. befruktadt med ofärgad buk Ångml. 18 Juli 74; befruktade ark:r med något gulaktiga bukar ÖG. 21 Aug. 72.

Distichium capillaceum Br. \& Sch. Bl.: VI. Fr.: (VI i slutet), VII. Hanbl.: anth:r tömda ÖG. Juli 69 och 20 Aug. 72; fulla eller tomma anth:r Nordl. 22 Aug. 70. Honbl.: ark:r öfvermogna med friska fötter och bukar ÖG. Juli 69 ; ark:r befruktade ÖG. 20 Aug. 72; vissnade ark:r, blott fötterna friska Nordl. 22 Aug. 70. 
Anm. Könsorganer mycket långsträckta; öppna ark:r med relativt mycket tjocka halsar, som uppåt strutlikt vidga sig.

Distichium inclinatum Br. \& Sch. Bl.: VI. Fr.: VII. Hanbl.: anth:r snart mogna N. Levanger 24 Juni 69; anth:r tomma Nordl. Juli 70. Honbl.: gamla Nordl. Juli 70.

Eucladium verticillatum Br. \& Sch. Bl.: X. Fr.: VI enligt förff.; frukt dock ej funnen i Skand. Honbl.: ark:r vissnade, fötterna dock temligen friska Gotl. Juni 65; dels gamla blr, dels en ung med parafyser och ett ungt, antheridlikt arkegonlag $0 \vec{G}$. omkring 1 Sept. 71; fullformade, slutna ark:r Tyskland Baireuth Okt. 70.

Didymodon rubellus Br. \& Sch. Bl.: V i slutet. Fr.: (VI i slutet), VII i början. Blr: snart mogna, samkönade blr, anth:r just mogna, endast få ark:r ännu fullformade Östersund 23 Juni 70; samkönade blr eller honblr, könsorganer af olika ålder, anth:r snart mogna, ark:r från ofärgade, men nảgot vissnade, och slutna till öppna och vissnade eller befruktade med ofärgad buk Nordl. i videbältet 29 Juli 70; samkönade blr, dels gamla, dels en årets med snart mogna anth:r och ett öfvermoget ark. Nordl. 22 Aug. 70.

D. rufus Lor. Bl.: ej undersökt. Frukt ej känd.

förff.

D. cylindricus Br. \& Sch. Bl.: VI. Fr.: X och XI enligt förff.; frukt dock ej funnen i Skand. Honbl.: just eller snart mogna, ark:r slutna eller öppna Sk. Juli 60.

Pottia latifolia C. Müll. Bl.: VI. Fr.: VI och VII. Honbl.: slutna eller oppna ark:r Dovre Juli 73; ark:r något öfvermogna, ännu friska Nordl. i björkregionen 4 Aug. 70 .

Anm. 4 ark:r räknades $\mathrm{i}$ en blomma.

P. lanceakata C. Müll. Bl.: VI i slutet och VII i början i analogi med P. truncata. Fr.: III, (IV).

P. Starkei C. Müll. Bl.: liktidig med följ:s ex analogia. Fr.: XI -II.

P. truncata Fürnr. Bl.: VI i slutet och VII i början. Fr.: (XI-)

I, II. Hanbl.: i en bl. anth:r tomma, i en annan ännu slutna Angml. 27 Juli 74. Honbl.: ark:r från slutna och ofärgade till befruktade med ofärgad buk Ångml. 27 Juli 74.

P. intermedia Fürnr. $B l$. : ex analogia liktidig med föreg:s. Fr.: II.

P. Heimii Fürnr. Bl.: VIII-början af X. Fr.: VI och början af

VII. Hanbl.: snart mogna, anth:r fullformade Trondhj:s st. Sept. 70. Honbl.: ark:r fullformade, slutna Trondhj:s st. Sept. 70.

Anm. 16 anth:r räknades $\mathrm{i}$ en blomma.

P. cavifolia Ehrh. Bl.: ex analogia liktidig med P. truncata. Fr.: II och början af III.

\section{Ordn. Seligeriaceae.}

Blindia acuta Br. \& Sch. $B l .:$ V i slutet och VI i början. Fr.: V, (VI). Hanbl.: snart mogna, anth:r slutna Nordl. 17 Juli 69; anth:r tomma ,OG. omkring 1 Sept. 71. Honbl.: ark:r friska, slutna eller öppna 
N. Aalesund 2 Juli 72; öfvermogna blr, ark:r med friska fotter Nordl 17 Juli 69 och 30 Aug. 70 saint ÖG. omkring 1 Sept. 71 . På ex. från sista stället visade sig äfven uppstickande, korta fruktskaft.

Anm. Ark:r 8 i en blomma. Ex. från ÖG. visade han- och honblr på samma individ och var således monoikt!

Stylostegium caespiticium Br. \& Sch. Bl.: V. Fr.: VII. Honbl.: något öfvermogna, dels ej befruktade, friska och öppna ark:r, dels befruktade med ofärgade bukar Dovre Juli 73.

Seligeria diversifolia Lindb. $B l$.: VI och början af VII, mest ex analogia. Fr.: V i slutet. Hanbl.: anth:r snart mogna, slutna Sala Juni? 36. Honbl.: fruktskaft utvecklade till full längd Finland Ö. Botn. Sept. 72.

S. recurvata Br. \& Sch. Bl.: VI och början af VII. Fr.: V i slutet. Hanbl.: anth:r ej mogna, slutna VG. 5-8 Juni 73; anth:r slutna eller öppna Nordl. 25 Juli och 10 Aug. 70 samt VG. 12 Aug. 69. Honbl.: ark:r dels befruktade, dels just mogna, öppna och friska Nordl. 25 Juli och 10 Aug. 70; ark:r öppna och friska VG. 13 Aug. 59; unga fruktskaft uppsticka Nordl. 5 Aug. 70.

S. crassinervis Lindb. Bl.: VI och början af VII ex analogia. Fr.: IV enligt Lindb. och Hn.

S. pusilla Br. \& Sch. Bl.: VI och början af VII ex analogia. Fr.: $\checkmark$ i slutet. Han-och honbl.: gamla VG. 8 Juni 73.

S. acutifolia Lindb. $B l$.: ex analogia liktidig med följ:s. Fr.: V i slutet enligt förff. och ex analogia.

S. tristicha Br. \& Sch. Bl.: VI och början af VII. Fr.: $\beta$ patula V i slutet; hufvudformen VII i Nordl. Hanbl.: anth:r snart mogna, slutna Nordl. i början af Juli och 28 Juli 69; anth:r ibland äfven tömda Nordl. 28 Juli 69. Honbl.: något ofvermogna Nordl. 28 Juli 69.

Anm. Anth:r 4 eller 6 i hvar blomma.

S. Donnii C. Müll. Bl.: VII i slutet och VIII i början i Nordl. Fr.: VII i VG., VIII och IX i Nordl. Hanbl.: anth:r snart mogna, ännu slutna Nordl. 15 Aug. 70 och 1 Sept. 69. Honbl.: ark:r friska, slutna eller öppna Nordl. 5 och 15 Aug. 70.

Anm. Könsorganernas antal 2, 4 eller 6 .

\section{Ordn. Fissidentiaceae.}

Octodiceras Julianum Brid. Blr ej funna af förf. på Svenska ex. Frukt ej funnen i Sverige.

Fissidens adianthoides H. Bl.: (V-) början af VII. Fr.: II i slutet, III, (IV). Honbl.: en bl. med friska, slutna eller öppna ark:r VG. 9 Juni 73 ; ark:r fullformade eller endast små antheridlika arkegonanlag Östersund 23 Juni 69 och Ångm!. 1 Aug. 74; gamla ark:r, ett befruktadt men felslaget Gotl. Juni 68.

Anm. 8 ark:r räknades $\mathrm{i}$ en blomma. Blrna med årets könsorganer utvecklade före den 1 Aug. måste anses såsom utvecklade på abnorma tider. Åtminstone var det sommaren 1874 vid Hernösand omöjligt att finna årsblr med utvecklade könsorganer före denna tid, ehuru förf. flerfaldiga gånger noggrant undersökte arten ute $\mathrm{i}$ naturen. 
Fissidens taxifolius H. Bl.: VII ex analogia. Fr.: II. Honbl.: gamla Trondhjem 28 Juni 69.

F. decipiens Not. Bl.: VII ex analogia. Fr.: II, (III) ex analogia, ej enligt förff.

F. osmundioides H. Bl.: (V-) början af VII. Fr.: II. Honbl.: ark:r vissnade Ångml. 3 Juni 70; öfvermogna, ark:r med fötterna och ibland äfven bukarna friska Sk. 11 Juni 73 (abnorm tid!) och Ångml. 3 Aug. 73; ark:r öppna, friska eller något vissnade Ångml. 6 Aug. 74 .

Anm. I en blomma räknades 28 ark:r, hvilket inom detta slägte är ett ovanligt stort antal.

F. pusillus Wils. Bl.: VII i början. Fr.: V.-Blr: dels samkönade blr, dels honblr, anth:r snart mogna och slutna, ark:r friska, slutna eller oftast öppna Nordl. 5 Aug. 70.

Anm. Denna art var i Nordl. polygam och hade utom honblr äfven samkönade blr. Härigenom hafva äfven samkönade blr blifvit funna inom detta slägte, hvilket $\mathrm{i}$ afseende på blommorna visar sig så intressant. Slägtets 8 Svenska arter kunna nemligen skiljas från hvarandra på karakterer hemtade från blrna, från könsförhållandena eller från blrnas läge. Serdeles intressant är dessutom inom slägtet dess vacklande mellan den akro- och kladokarpiska typen.

F. incurvus Schwægr. Bl.: i början af VII. Fr.: II och början af III. Honbl.: gamla med vissnade ark:r Stockh. 3 Juni 64 och Angml. 7 Juli 74; just mogna med friska, slutna eller öppna ark:r Stockh. Juli 72 och Angml. 28 Juli 74.

F. bryoides H. Bl.: VII i början ex analogia. Fr.: II och början af III.

F. exilis H. och Sch. Syn. Bl.: VII i början ex analogia. Fr.: II och början af III.

\section{Ordn. Leucobryaceae.}

Leucobryum glaucum Sch. Bl.: VI. Fr.: III, mest i analogi med andra för hösten och vintern angifna arter. Honbl.: gamla Gotl. Juli 61; just mogna, flesta ark:r öppna Tyskland Juli 73.

Anm. Ark:r ovanligt stora med mycket långa halsar.

\section{Ordn. Weissiaceae.}

Campylopus atrovirens Not. Blr ej funna af förf. Frukt ej känd.

C. flexuosus Brid. Bl.: VI. Fr.: V. Hanbl.: alla anth:r fulla, få öppna Bergens st. Sogn 2 Juli 67; anth:r just mogna, fulla eller tomma N. Aalesund 3 Juli 72.

C. fragilis Br. \& Sch. Bl.: VI ex analogia. Fr.: V.

C. turfaceus Br. \& Sch. Bl.: VI ex analogia. Fr.: V ex analogia och enligt förff.

C. Sehwarzii Sch. Bl.: VI ex analogia. Frukt ej känd.

Dicranodontium longirostre $\mathrm{Br}$. \& Sch. Bl.: VI. Fr.: XI enligt förff. Honbl.: något öfvermogna ark:r Smål. Juli 66.

D. aristatum Sch. Bl.: VI i analogi med föreg. Frukt ej känd(?). Honbl.: gamla N. Aalesund 11 Juli 68. 
Dicranum robustum Blytt. Bl.: VI, (VII). Fr.: VI. Hanbl.: anth:r mogna Ångml. 18 Juli 74. Honbl.: ark:r fullformade, slutna Ångml. 8 Juli 73; ark:r slutna eller öppna och friska Ångml. 18 Juli 74.

Anm. Anth:rnas antal hos denna art och den följande $4 \mathrm{i}$ hvar blomma. Endast dvärghanplantor finnas hos dessa 2 arter, likasom hos de 4 följ., ej med honplantan lika stora hanplantor. Anth:rna äro $i$ jemförelse med ark:rna mycket små och hafva en ovanligt mycket rundad form, närmande sig till den hos Buxbaumia, Sphagna och Hepaticae vanliga runda formen. Hanparafyserna äro hos denna art och den följande gula, honparafyserna deremot ofärgade.

D. undulatum H. Bl.: VI, VII. Fr.: (VIII)-XI. Hanbl.: just mogna Ångml. 28 Juli 74 . Honbl.: just mogen Ångml. 30 Juli 73; något öfvermogna, ark:r friska och öppna, ett befruktadt med ofärgad buk ÖG. 11 Aug. 70 .

D. palustre Brid. Bl.: VI, VII. Fr.: (VIII-)XI. Honbl.: ark:r öppna och friska ÖG. 17 Aug. 70.

D. Schraderi WM. Bl.: VI, VII i Sverige. Honbl.: blott parafyser utvecklade Ner. 11 Maj 73; just mogna Ångml. i början af Aug. 72.

Anm. Ark:rnas antal 16 i en blomma. Denna art och de i Nordl. förefintliga Dicrana Scoparia torde derstädes blomma redan tidigt på våren i III eller IV, likasom D. fuscescens och elongatum.

D. spurium H. Bl.: VI. Fr.: V i slutet och VI i början. Honbl.: ark:r fullformade, slutna Angml. 5 Juli 73 ; öfvermogen blomma, ark:r föga vissnade, ett befruktadt med hvitgrön buk Ångml. 30 Juli 73.

D. majus Turn. Bl.: VI, VII i Sverige. Fr.: (VIII-)XI. Honbl.: just mogen Ångml. 25 Juli 73.

D. scoparium H. Bl.: VI, VII i Sverige. Fr.: (VIII-)XI. Honbl.: något öfvermogen, ett ark. befruktadt med hvit buk Ångml. 3 Aug. 73.

D. Mühlenbeckii Br. \& Sch. Bl.: VI och VII i Sverige ex anal. Fr.: (VIII)-XI.

D. fuscescens Turn. Bl.: III eller IV i Nordl.; VI, VII i Sverige. Fr.: (VIII-)XI. Honbl.: just mogna Angml. 5 Juli 73 och Aug. 72; 1 till 2 linier långa fruktskaft uppstucko, dessutom förefunnos fullformade gröna frukter Nordl. 6 Juli 70.

D. elongatum Schwægr. Bl.: III eller IV i Nordl.; VI och VII ex analogia i Sverige. Fr.: (VIII-)XI. Hanbl.: anth:r tomma, synas tillhöra en årets blomma Nordl. 5 Juli 70. Honbl.: öfvermogen, ett ark. befruktadt med hvitgrön buk, de öfriga med friska fötter Nordl. 6 Juli 70; vissnade ark:r med friska fötter Nordl. 19 Juni 70.

D. fragilifolium Lindb. $B l .:$ V, början af VI. Fr.: (VIII-)XI. Honbl.: just mogen, ark:r friska och öppna S. N. Gudbrandsdalen Juni 65.

D. strictum Schleich. Bl.: V och början af VI. Fr.: V enl. förff.; frukt dock ej funnen i Sverige. Honbl.: dels en gammal fjolårets, dels en årets, den senare med snart fullformade ark:r Gotl. Juni 65. 
Dicranum viride Sch. Bl.: V i slutet och VI i början. Fr.: VI enligt Milde; frukt dock ej funnen i Sverige. Honbl.: öfvermogna, ark:r med nästan blott fötterna friska Finland Tavastland 6 Aug. 68 .

D. Scottianum Turn. Bl.: VI, VII ex analogia. Fr.: (VIII-)XI.

D. albicans Br. \& Sch. Bl.: VI. Fr.: (VIII-)XI; frukt dock ej funnen i Skand. Honbl.: öfvermogna, ark:r med blott fötterna friska Pit. Lapm. Aug. 56.

Anm. I Nordl. och på Dovre synes arten oftast sakna blr; förf. lyckades åtminstone ej finna blr på talrika ex. från dessa trakter.

D. Sauteri Br. \& Sch. Bl. och Fr.: ex anal. liktidiga med följ:s. Frukt dock ej funnen i Skand.

D. longifolium H. Bl.: VI?, VII. Fr.: (VIII-)XI. Honbl.: just mogna, ett par ark:r ännu slutna, de öfriga öppna Ångml. 6 Aug. 73. Anm. Ark:rnas antal 8 i en blomma.

D. fulvum Hook. Bl.: VI eller VII ex anal. Fr.: (VIII-)XI enl. förff.; frukt dock ej funnen i Sverige.

D. flagellare H. Bl.: VII?, VIII och IX. Fr.: (VIII-)XI. Honbl.: just mogen Gefle Sept. 70.

D. montanum H. Bl.: VII. Fr.: VIII. Honbl.: ark:r fullformade, slutna Öl. 25 Juli 67 ; något öfvermogna, ett ark. befruktadt Upsala 15 Aug. 60 .

D. areticum Sch. Bl.: VI-(VIII). Fr.: (VII-)XI. Honbl.: ark:r friska, slutna eller öppna Nordl. i lafbältet 27 Aug. 70.

D. Starkei WM. $B l .: \mathrm{V}$ i slutet och VI; genom sin alpina växtlokal dock oftast liktidigt med VIII och IX i låglandet. Hanbl.: anth:r slutna eller öppna, fulla eller nyss tömda Nordl. 20 Aug. 70. Honbl.: ark:r fullformade, slutna Nordl. 20 Aug. 70; halfvuxna fruktskaft Bergen 31 Ang. 71.

Anm. 16 anth:r räknades $i$ en blomma.

D. falcatum $H$. $B l$.: V i slutet och VI i början; dock oftast lik tidigt med VIII och IX i låglandet genom artens alpina växtlokal. Fr.: V, VI. Hanbl.: anth:r just mogna, ett t. 0. m. tömdt Nordl. 16 Aug. 70. Honbl.: ark:r ej ännu fullformade Nordl. 16 Aug. 70; ark:r friska, slutna eller öppna Nordl. 3 Sept. 70. På båda ställena tagen i lafbältet.

D. Blyttii Br. \& Sch. Bl.: V i slutet och VI i början. Fr.: V. Hanbl.: anth:r öppna, fulla eller tomma Ångml. 5 Juli 73. Honbl.: ark:r friska, slutna eller öppna Ångml. 5 Juli 73 och 6 Juli 74 .

D. fulvellum Sm. $B l .: \mathrm{V}$ i slutet och VI i anal. med föreg. $\boldsymbol{F r}$.: $\checkmark$ och VI pà fjällen, oftast liktidigt med VIII och IX i låglandet. Honbl.: gamla Nordl. 1 Sept. 70.

Anm. 4 ark:r räknades $\mathrm{i}$ en blomma.

D. hyperhoreum C. Müll. Bl.: V i slutet och VI. Fr.: V(-VII). Hanbl.: gamla Dovre Juli 73. Honbl.: ark:r unga, ej ännu fullformade eller just mogna och öppna Dovre Juli 73.

b. Anderssonii Sch. $B l$ : $\mathrm{V}$ i slutet och VI i analogi med de föreg. Fr.: V eller VI enligt förff. Ej sedd af förf. 
Dicranella heteromalla Sch. Bl.: VIII och IX. Fr.: (XI-) I, II. Hanll.: just mogna, anth:r slutna eller öppna ÖG. omkring 1 Sept. 71 Honbl.: just mogna, ark:r slutna eller öppna ÖG. omkring 1 Sept. 71.

D. subulata Sch. Bl.: VIII och IX. Fr.: (XI-) I, II. Hanbl.: just öfvermogna, några anth:r ännu ej fullt tömda Gefle Okt. 70. Honbl.: öfvermogna, ett ark. befruktadt med ofärgad buk Gefle Okt. 70.

D. curvata Sch. Bl.: VIII och IX i analogi med föreg. Fr.: (XI -)I, II.

D. varia Sch. Bl.: IV i slutet och V i början. Fr.: I-(III). Hanbl.: gamli Öl. 30 Sept. 70. Honbl.: ark:r unga, oftast ännu ej fullformade Ångml. 16 Juni 74; ark:r just mogna Ångml. 28 Juni 74; gamla och vissnade ark:r Öl. 30 sept. 70.

D. rufescens Sch. $B l$.: IV i slutet och V i början. Fr.: (XII), I, II, (III). Hanbl.: just mogna, anth:r fulla eller tomma Ångml. 7 Juli 74. Honbl.: ark:r gamla och vissnade Ångml. Okt. 73 och Gefle Okt. 71.

D. cerviculata, Sch. Bl.: VIII och IX. Fr.: (XI-)I, II. Hanbl.: anth:r fulla, några dock öppna ÖG. omkring 1 Sept. 70; just mogna, anth:r mer eller mindre tömda Nordl. 1 Sept. 70. Honbl.: ark:r fullformade, ännu slutna Nordl. 1 Sept. 70.

D. squarrosa Sch. Bl.: V. Fr.: I, II. Honbl.: just mogna, ark:r slutna eller öppna Nordl. 6 Juli 70.

D. Schreberi Sch. Bl.: IV i slutet och V i början. Fr.: I, II. Honbl.: gamla, ark:r vissnade Örebro Sept. 72 och Okt. 70.

D. Grevillei Sch. $B l$.: IV i slutet och Vøi början. Fr.: I, II. Honbl.: öfvermogna blr, befruktade ark:r oftast med grön, ett dock med ofärgad buk Nordl. 12 Juli 69; unga fruktskaft börja uppsticka Nordl. 17 Juli 70; ark:r vissnade Uppl. 12 Juli 67.

D. crispa Sch. Bl.: IV i slutet och V i början. Fr.: I, II. Hanbl.: anth:r snart mogna, ännu slutna Ångml. 8 Juni 69 och 15 Juni 74. Honbl.: endast ytterst små arkegonanlag Ångml. 8 Juni 69 ; ark:r slutna eller öppna, friska Ångml. 15 Juni 74; ett ark. befruktadt med of ärgad buk Trondhjem 28 Juni 69 .

Anm. Angående den olika tid, som arterna af detta slägte behöfva för fruktens utveckling, se sid. 74 .

Ångströmia longipes Br. \& Sch. Bl.: IV i slutet och V i början. Fr.: (I), II, (III). Hanbl.: anth:r snart mogna, slutna Dovre 16 Juni 65; anth:r tomma Tyrolen Aug. 67. Honbl.: dels gamla blr med vissnade ark:r och ett befruktadt, felslaget, dels årets blr med slutna eller öppna, friska ark:r Dovre 16 Juni 65; gamla Tyrolen Aug. 67.

Trematodon ambiguus Hornsch. Bl.: VIII och IX. Fr.: VIII och IX. Hanbl.: just mogna, anth:r fulla eller tomma Ångml. 31 Aug. 74. Honbl.: gamla Nordl. 16 Aug. 70.

A nm. Hanblr med $3-6$ anth:r.

T. brevicollis Hornsch. Bl.: VII. Fr.: VIII och IX. Hanbl.: anth:r snart mogna, slutna Nordl. i björkregionen 4 Aug. 70. Honbl.: något öfvermogna, ark:r oftast med friska bukar Nordl. 4 Aug. 70; ark:r med friska bukar, något vissnade halsar Dovre Aug. 73. 
Dichodontium pellucidum Sch. Bl.: (IV) V. Fr.: I, II. Hanbl.: anth:r fullformade, temligen unga VG. 5 Juni 73. Honbl.: något öfvermogna med öppna, friska ark:r Nordl. 3 Juli 70.

Anm. 12 ark:r räknades $\mathrm{i}$ en honblomma.

Cynodontium virens Br. \& Sch. Bl.: IV i slutet och V i början. Fr.: IV. Honbl.: endast få ark:r ännu fullformade Jemtl. 20 Juni 70; offermogna, befruktade ark:r med grön buk, ej befruktade med endast fötterna friska Nordl. 3-5 Juli 70 .

Anm. I ett par honblr räknades 4 ark:r. Denna art, likasom den nästa, synes blomma något tidigare i Nordl., än i Sverige, eller i början af IV eller möjligen äfven i III.

C. Wahlenbergii (Brid.) $B l$.: IV i slutet och i början af V. Fr.: IV. Hanbl.: anth:r ej mogna, slutna Ångml. 20 Juni 74 och 5 Juli 73. Honbl.: ark:r fullformade, slutna Ångml. 20 Juni 74; ark:r friska, slutna eller öppna Ångml. 5 Juli 73; öfvermogna, ett ark. befruktadt med grön buk Nordl. 3 Juli 70; linielånga, uppstickande fruktskaft Ångml. 25 Juli 73.

C. Bruntoni Br. \& Sch. Bl.: V. Fr.: V--början af VII. Hanbl.: dels gamla blr med tomma anth:r, dels derofvan unga med ännu slutna anth:r ÖG. Juni 55; gamla ÖG. 20 Aug. 73. Honbl.: dels gamla, dels unga, de senare med fullformade, slutna ark:r ÖG. Juni 55; gamla ÖG. 20 Aug. 73; halfvuxna fruktskaft Ner. Okt. 73.

C. polycarpum Sch. Bl.: VI, VII. Fr.: V i slutet-VII. Hanbl.: blr dels just mogna, dels öfvermogna Ångml. Aug. 72. Honbl.: dels just mogna med friska ark:r, dels öfvermogna med befruktade ark; r med gröna bukar eller med uppstickande, korta fruktskaft Ángml. Aug. 72; något öfvermogna, bukar dock ännu friska ÖG. 19 Aug. 70.

C. gracilescens Sch. Bl.: VI, VII. Fr.: V i slutet-VII. Hanbl.: ej ännu mogna Ångml. 4 Juli 72. Honbl.: ett ark. fullformadt, de ofriga antheridlika Ångml. 4 Juli 72; öfvermogna, ett ark. befruktadt med grön buk Ångml. Aug. 72.

Weissia Schisti Brid. $B l .:$ V i slutet. Fr.: III i slutet. Hanbl.: anth:r ej mogna, slutna Jemtl. Juni 69 cch Ångml. 29 Juni 74; tömda års-anth:r Angml. 3 Aug. 73. Honbl.: gamla Jemtl. i början af Juni 71; ark:r fullformade, snart mogna Ångml. 29 Juni 74; korta fruktskaft börja uppsticka Angml. 3 Aug. 73.

W. denticulata Brid. Bl.: V i slutet ex analogia. Fr.: III i slutet, mest ex analogia.

W. fugax H. Bl.: V i slutet. Fr.: III i slutet. Hanbl.: anth:r tömda Nordl. 17 Juli 70. Honbl.: just mogna Nordl. 4 Juli 69; öfvermogna Nordl. 17 Juli 69.

W. crispula $H . \quad B l .:$ V. Fr.: III. Hanbl.: anth:r snart mogna Ångml. 5 Juli 73 cch Nordl. 17 Juli 70. Honbl.: ark:r fullformade, slutna Ångml. 5 Juli 73; något öfvermogna blr, ett ark. befruktadt, de öfriga öppna med bruna halsar Nordl. 17 Juli 70; fruktskaft ofta af full lăngd Ångml. 20 Juli 74.

W. compacta Brid. $B l$. och Fr.: ex analogia liktidiga med föreg:s. 
Weissia cirrhata H. Bl.: V. Fr.: III. Honbl.: öfvermogna, arkar med endast fōtterna eller ibland äfven nedre delarne af bukarne friska ÖG. omkring den 1 Aug.

W. viridula Brid. Bl.: V i början. Fr.: IV. Honbl.: dels gamla blr, dels blr med linielånga, uppstickande fruktskaft Gotl. 15 Juli 58.

W. Wimmeri Br. \& Sch. Bl.: V i början i analogi med föreg. $B r .:$ III i slutet.

Anoectangium compactum Schwægr. Bl,: V? Fr.: X. Hanbl.: anth:r slutna, några dock bruna Dovre Aug. 54; dels gamla blr, dels snart mogna Nordl. 15 Aug. 70. Honbl.: dels gamla blr, dels årets, de senare med något vissnade ark:r med oftast friska bukar N. Aalesund 11 Juli 68; unga fruktskaft af nästan full längd $\mathrm{N}$. Romsdalen Juli 72; gamla blr Nordl. 15 Aug. 70.

Gymnostomum curvirostre H. Bl.: V. Fr.: V. Honbi.: unga setor uppsticka Nordl. i början af Juli 70; ark:r med fötterna och nedre delarne af bukarne friska Nordl. 19 Juli 70; öfvermogna, ark:r med endast fötterna friska Nordl. 8 Aug. 70.

G. rupestre Schwægr. Bl.: V. Fr.: III. Hanbl.: gamla VG. 5 Juni 73. Honbl.: just mogna, ark:r slutna eller öppna VG. 5 Juni 73 och Gotl. i början af Juni 65 .

G. tenue Schrad. Bl.: V eller VI. Fr.: VI enligt förff. och enligt ex. Hanbl.: anth:r snart mogna Genève Juni 68.

G. calcareum Nees \& Hornsch. Bl.: V. Fr.: IV? Honbl.: blr dels gamla, dels årets, de senare dels med ej ännu fullformade ark:r, dels med något öfvermogna med friska bukar Genève Juni 68.

G. microstomum H. Bl.: V. Fr.: IV. Honbl.: ark:r unga, stundom fullformade, ett t. 0. m. öppet VG. 2 Juni 73.

G. squarrosum Wils. $B$ l.: $V$ i analogi med föreg. Fr.: I, II.

Systegium erispum Sch. Bl.: V ex analogia. Fr.: IV.

\section{Musci cleistocarpi.}

\section{Ordn. Archidiaceae.}

Archidium alternifolium Sch. Bl.: VI ex analogia. Fr.: IV-VI, mest enligt förff.

Anm. Vid denna och de öfriga kleistokarpa mossorna kan förf. endast ex analogia sluta till blomningstiden. Dessa mossor förekomma nemligen troligen aldrig i herbarier med friska blr, och förf. har ej heller haft tillfälle att studera dem i naturen, emedan förf. mestadels vistats utom dessa mossors utbredningsregion, àtminstone under deras sannolika blomningstid.

\section{Ordn. Phascaceae.}

Sporledera palustris Hampe. Bl.: V eller VI ex analogia. Fr.: $V$, mest enligt förff.

Pleuridium alternifolium Rabenh. Bl.: V eller VI ex analogia. Fr.: IV. 
Pleuridium subulatum Rabenh. $B l .: \quad \mathrm{V}$ eller VI ex analogia. Fr.: IV.

P. nitidum Rabenh. $B l$.: V eller VI ex analogia. Fr.: XI.

Phascum bryoides Dicks. Bl.: VI ex analogia. Fr.: IV, V.

P. cuspidatum Schreb. Bl.: VI ex analogia. Fr.: IV.

Sphaerangium muticum Sch. Bl.: VI ex analogia. Fr.: I-III.

Microbryum Flörkei Sch. $B l$.: VI ex analogia. Fr.: II-III enligt förff.

Ephemerella recurvifolia Sch. Bl.: VI ex analogia. Fr.: XI, (XII).

Physcomitrella patens Sch. Bl.: V eller VI ex analogia. Fr.: XI, (XII).

Ephemerum serratum Hampe. Bl.: VI ex analogia. Fr.: XI, (XII).

\section{Musci schizocarpi.}

\section{Ordn. Andraeaceae.}

Andraea nivalis Hook. Bl.: III och IV i analogi med A. petrophila. Fr.: III och IV i analogi med densamma.

Anm. Denna och de följande på högfjällen nära den eviga snöns gräns växande Andraea-arterna blomma troligen alla och få mogna frukter på den tid, som motsvarar III och IV perioderna i låglandet. Såsom vi redan förut sagt, kan dock ej så högt uppe i lafbältet året sönderdelas i 12 utvecklingsperioder, utan torde det der endast finnas 2 årstider, en vinter och en vår. Under vintern står naturligtvis den vegetativa utvecklingen stilla, hvarför det är endast under våren, som blomning och fruktmognad kunna hos der växande mossor inträffa.

A. Blyttii Sch. $B l$. och Fr.: liktidiga med föregåendes.

A. erassinervis Bruch. Bl.: III och IV. Fr.: III i slutet och IV i början. Honbl.: ark:r befruktade, redan gröngula Ångml. 5 Juli 74.

A. rupestris Turn. Bl. och Fr.: liktidiga med föreg:s.

A. Hartmani Thed., A. alpina Turn., A. obovata Thed., A. alpestris Sch. $B l$. och $F r$.: se anmärkningen vid A. nivalis.

A. petrophila Ehrh. Bl.: (II), III, IV. Fr.: III i slutet och IV i början. Hanbl.: anth:r snart mogna, slutna Ångml. 11 Juni 74. Honbl.: öfvermogna, ark:r dels befruktade, dels ej befruktade, de senare med friska fötter Upsala 20 April 55 och Ångml. 11 Juni 74; ark:r befruktade eller helt och hållet vissnade Ner. 18 Juni 60 och Angml. 8 Juli 73; ark:r fullformade, snart mogna Ångml. Juni 68.

Anm. 16 anth:r räknades $\mathrm{i}$ en hanblomma, 4 ark:r $\mathrm{i}$ en honblomma.

A. sparsifolia Zett., A. papillosa Lindb., Bl.: och Fr.: se anm. vid A. nivalis. 

